\title{
Evaluation of the Location and Recency of Faulting Near Prospective Surface Facilities in Midway Valley, Nye County, Nevada
}

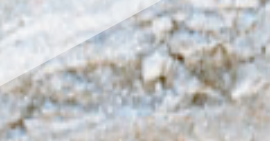

U.S. Department of the Interior 


\section{Evaluation of the Location and Recency of Faulting Near Prospective Surface Facilities in Midway Valley, Nye County, Nevada}

ByF.H. Swan, J.R. Wesling, M.M. Angell, A.P. Thomas, J.W. Whitney, and J.D. Gibson

U.S. Geological Survey Open-File Report 01-55

Prepared in cooperation with the Nevada Operations Office,

U.S. Department of Energy (Interagency Agreement DE-Al08-97NV12033)

U.S. Department of the Interior

U.S. Geological Survey 


\title{
U.S. Department of the Interior
}

\author{
Gale A. Norton, Secretary
}

\section{U.S. Geological Survey \\ Charles G. Groat, Director}

First printing November 2001, version 1.0

For sale by U.S. Geological Survey, Information Services

Box 25286, Denver Federal Center

Denver, CO 80225

\author{
Any use of trade, product, or firm names in this publication \\ is for descriptive purposes only and does not \\ imply endorsement by the U.S. Government \\ For additional information write to: \\ Chief, Earth Science Investigations Program \\ Yucca Mountain Project Branch \\ U.S. Geological Survey \\ Box 25046, Mail Stop 421 \\ Denver Federal Center \\ Denver, C0 80225-0046
}




\section{Contents}

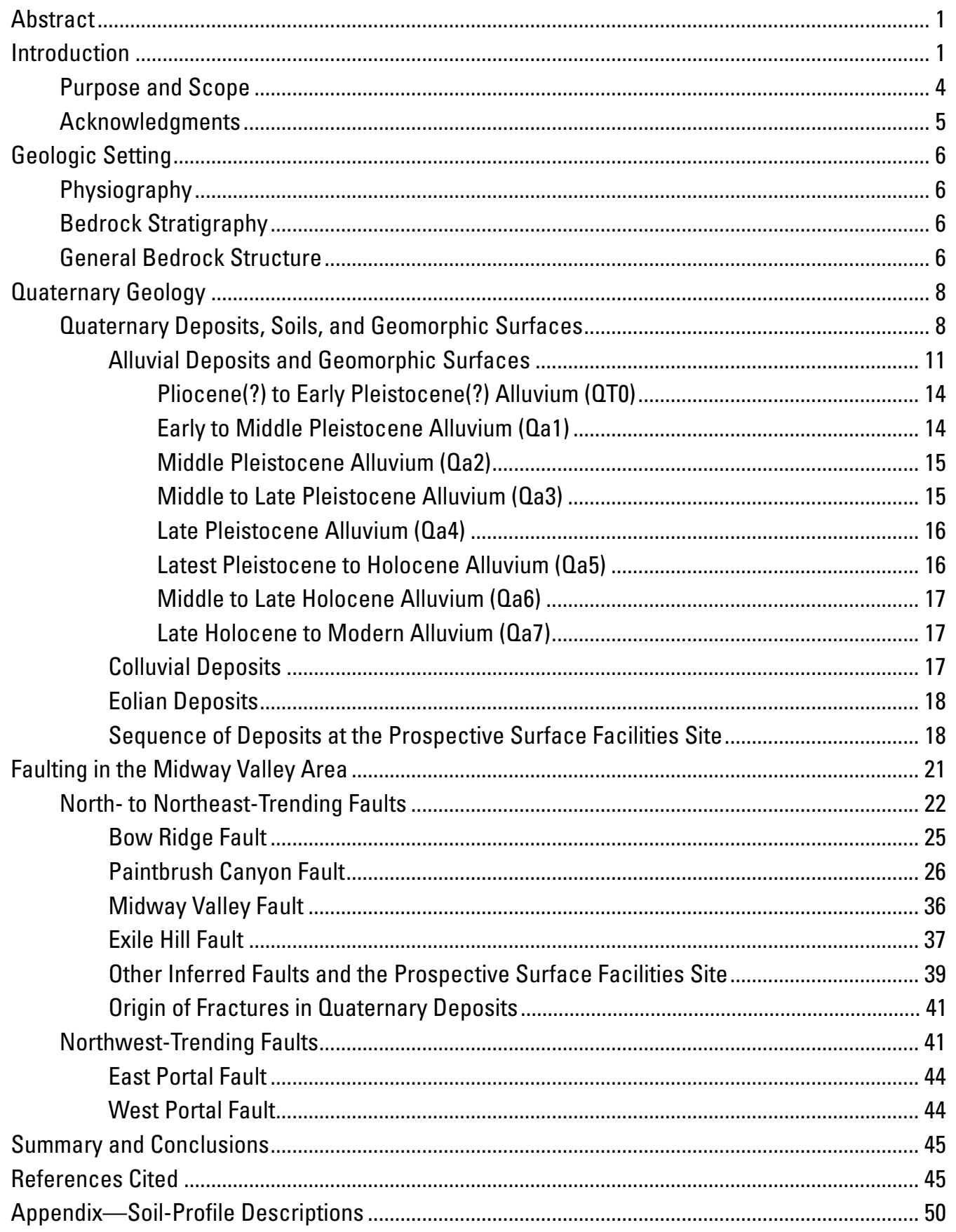




\section{Plates}

1. Geologic map of Exile Hill area

2. Map of prospective facilities site

3. Map showing geophysical survey lines and features interpreted from geophysical data

4-7. Logs of:

4A. Trench MWV-T5, (stations 0-200)

4B. Trench MWV-T5, (stations 200-340)

5. Trench MWV-T4

6. Trench MWV-T7

7. Trench A/BR-3

8. Log and map of North Portal Duct Bank excavation

9. Logs of soil test pits

\section{Figures}

1-2. Locality maps showing:

1. Faults and geographic features in Yucca Mountain-Midway Valley area............... 2

2. Prospective sites for repository surface facilities in Midway Valley, area of Quaternary mapping, and trench locations ...................................................... 3

3-4. Photographs of:

3. Prospective surface facilities site and trenches MWV-T5 and MWV-T7

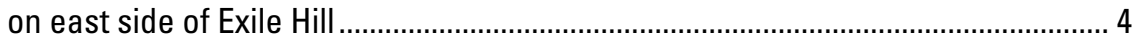

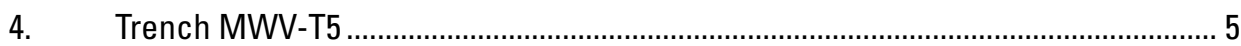

5-6. Maps showing:

5. Regional tectonic setting of Yucca Mountain ......................................................... 7

6. Surficial geology and trench, borehole, and soil pit locations in vicinity of prospective surface facilities site

7. Schematic section showing stratigraphic relations among bedrock, alluvium, and colluvium

8. Photograph showing sequence of surficial deposits, south wall of trench MWV-T5.

9A. Structure section across Midway Valley by Scott and Bonk (1984) ............................... 22

9B. Structure section across Midway Valley by Day and others (1998) ................................. 23

9C. Generalized geologic section across Exile Hill and west-central Midway Valley

10. Map showing location of trench A/BR-3 and surficial geology in surrounding area 
11. Graphs showing results of gravity and ground magnetic surveys

in Midway Valley...

12. Map showing location of trench MWV-T4 and surficial geology

in southern Midway Valley.

13-17. Photographs of:

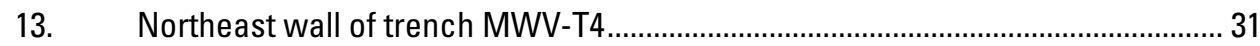

14. Exile Hill and East Portal faults in North Portal Duct Bank excavation ................... 38

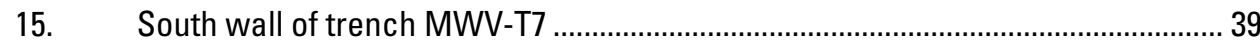

16. Carbonate-filled fracture in trench MWV-T7 ...................................................... 40

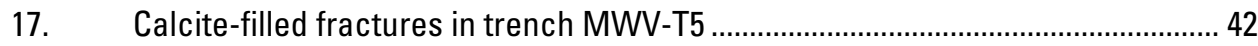

A1. Map showing locations of soil test pits and boreholes in Midway Valley........................ 51

\section{Tables}

1. Principal stratigraphic units in the Yucca Mountain area ................................................ 6

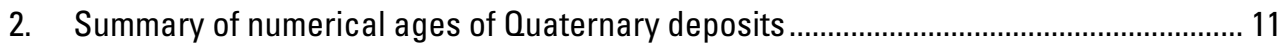

3. Summary of surface and soil properties of Quaternary map units ................................... 12

4. Correlation of surficial units in Midway Valley with local and regional surficial sequences ....................................................................................................... 13

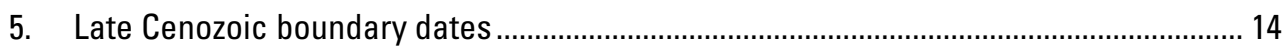

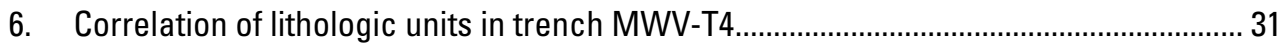

7. Summary of fault displacements, trench MWV-T4 ……............................................... 34

8. Late Quaternary fault slip rates, trench MWV-T4 ……................................................. 35

9. Estimated average recurrence interval for surface-fault ruptures

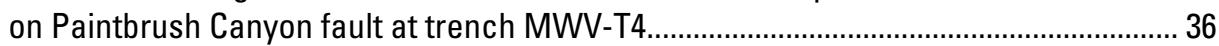

10 Characteristics of fractures in eastern fracture zone..................................................... 43

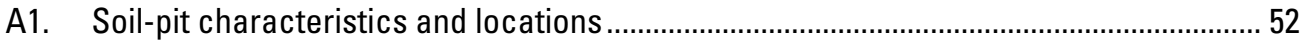

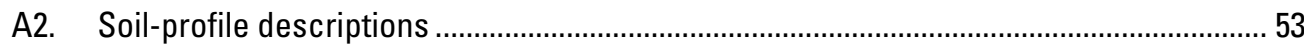

\section{Conversion Factors}

\begin{tabular}{lll}
\hline \multicolumn{1}{c}{ Multiply } & By & To obtain \\
\hline kilometer $(\mathrm{km})$ & 0.6214 & mile \\
meter $(\mathrm{m})$ & 3.2808 & feet \\
centimeter $(\mathrm{cm})$ & 0.3937 & inch \\
millimeter $(\mathrm{mm})$ & 0.0394 & inch \\
millimeters per year $(\mathrm{mm} / \mathrm{yr})$ & 0.0394 & inches per year \\
\hline
\end{tabular}




\section{Abbreviations}
$\mathrm{ka} \quad$ thousands of years before present
k.y. $\quad$ thousand years
Ma millions of years before present

Sea level: In this report "sea level" refers to the National Geodetic Vertical Datum of 1929

(NGVD of 1929) - a geodetic datum derived from a general adjustment of the first-order level nets of both the United States and Canada, formerly called Sea Level Datum of 1929. 


\title{
Evaluation of the Location and Recency of Faulting Near Prospective Surface Facilities in Midway Valley, Nye County, Nevada
}

\author{
By F.H. Swan, ${ }^{1}$ J.R. Wesling, ${ }^{1}$ M.M. Angell, ${ }^{1}$ A.P. Thomas, ${ }^{1}$ \\ J.W. Whitney, ${ }^{2}$ and J.D. Gibson ${ }^{3}$
}

\section{Abstract}

Evaluation of surface faulting that may pose a hazard to prospective surface facilities is an important element of the tectonic studies for the potential Yucca Mountain high-level radioactive waste repository in southwestern Nevada. For this purpose, a program of detailed geologic mapping and trenching was done to obtain surface and near-surface geologic data that are essential for determining the location and recency of faults at a prospective surface-facilities site located east of Exile Hill in Midway Valley, near the eastern base of Yucca Mountain.

The dominant tectonic features in the Midway Valley area are the north- to northeast-trending, west-dipping normal faults that bound the Midway Valley structural block-the Bow Ridge fault on the west side of Exile Hill and the Paintbrush Canyon fault on the east side of the valley. Trenching of Quaternary sediments has exposed evidence of displacements, which demonstrate that these block-bounding faults repeatedly ruptured the surface during the middle to late Quaternary.

Geologic mapping, subsurface borehole and geophysical data, and the results of trenching activities indicate the presence of north- to northeast-trending faults and northwest-trending faults in Tertiary volcanic rocks beneath alluvial and colluvial sediments near the prospective surface-facilities site. Northto northeast-trending faults include the Exile Hill fault along the eastern base of Exile Hill and faults to the east beneath the surficial deposits of Midway Valley. These faults have no geomorphic expression, but two north- to northeast-trending zones of fractures exposed in excavated profiles of middle to late Pleistocene deposits at the prospective surface-facilities site appear to be associated with these faults. Northwest-trending faults include the West Portal and East Portal faults, but no disruption of Quaternary deposits by these faults is evident.

\footnotetext{
${ }^{1}$ Geomatrix Consultants, Inc., San Francisco, California.

2 U.S. Geological Survey, Denver, Colorado.

${ }^{3}$ Sandia National Laboratories, Albuquerque, New Mexico.
}

The western zone of fractures is associated with the Exile Hill fault. The eastern zone of fractures is within Quaternary alluvial sediments, but no bedrock was encountered in trenches and soil pits in this part of the prospective surface facilities site; thus, the direct association of this zone with one or more bedrock faults is uncertain. No displacement of lithologic contacts and soil horizons could be detected in the fractured Quaternary deposits. The results of these investigations imply the absence of any appreciable late Quaternary faulting activity at the prospective surface-facilities site.

\section{Introduction}

An important part of site-characterization studies of a potential high-level radioactive waste repository at Yucca Mountain, Nevada, is an evaluation of Quaternary fault activity in Midway Valley that may affect the siting of prospective surface facilities for waste handling (fig. 1). Neal (1985) identified six candidate areas as locations for potential sites. Four of these areas are located within Midway Valley, one of which-candidate area 3, referred to as the Reference Conceptual Site (RCS) - was considered to be the most favorable location (fig. 2). Because there was insufficient information about faulting in the Midway Valley area to discriminate among the candidate sites identified by Neal (1985), a program of exploratory core drilling and seismic reflection and refraction surveys was undertaken (Neal, 1986). The results of those investigations indicated that closely spaced normal faults in the Tertiary bedrock beneath the RCS are likely; however, the data provided no information as to whether such faults also displaced the overlying unconsolidated sediments. Accordingly, a program of detailed geologic investigations was proposed by the U.S. Department of Energy (1988) to acquire surface and near-surface geologic information on the stratigraphic and structural relations of the Quaternary and Tertiary surficial deposits and Tertiary bedrock in Midway Valley to evaluate the potential for future surface ruptures 
caused by faulting (see Gibson and others, 1990, 1992). The primary objectives were to (1) conduct geologic mapping in sufficient detail to establish a chronostratigraphy of surficial deposits, (2) investigate faults known or suspected to have been active during the Quaternary, and (3) identify and excavate trench locations, primarily at the RCS, that would yield essential information for assessing the potential for surface fault rupture. The resulting data, combined with data from other Yucca Mountain site-characterization activities, were used to support site determinations for the prospective surface facilities and to assess the potential effects of surface faulting on the design of such facilities.

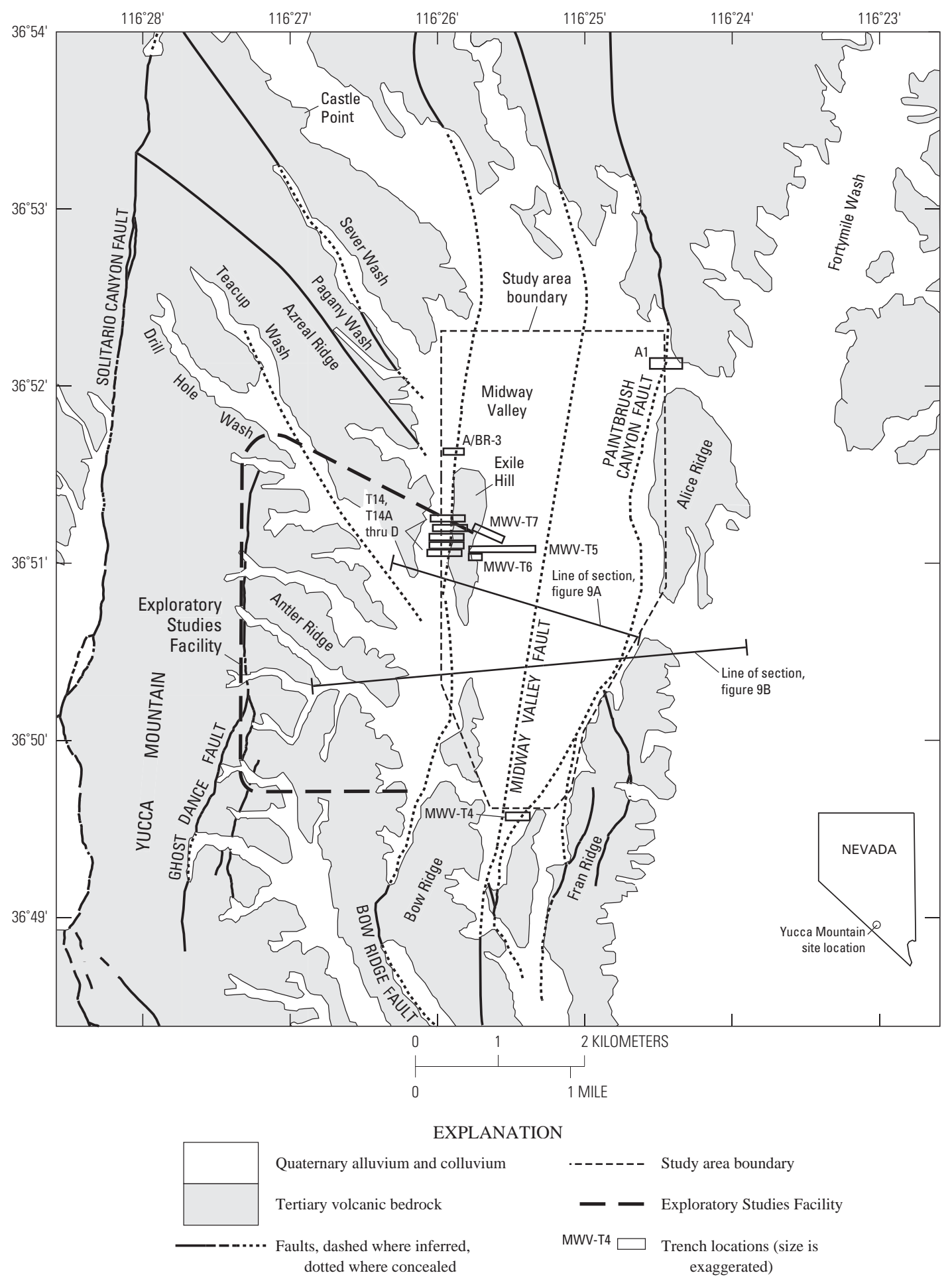

Figure 1. Index map showing named faults and geographic features in the Yucca Mountain-Midway Valley area, Nevada. Fault locations adapted from Day and others (1998). 


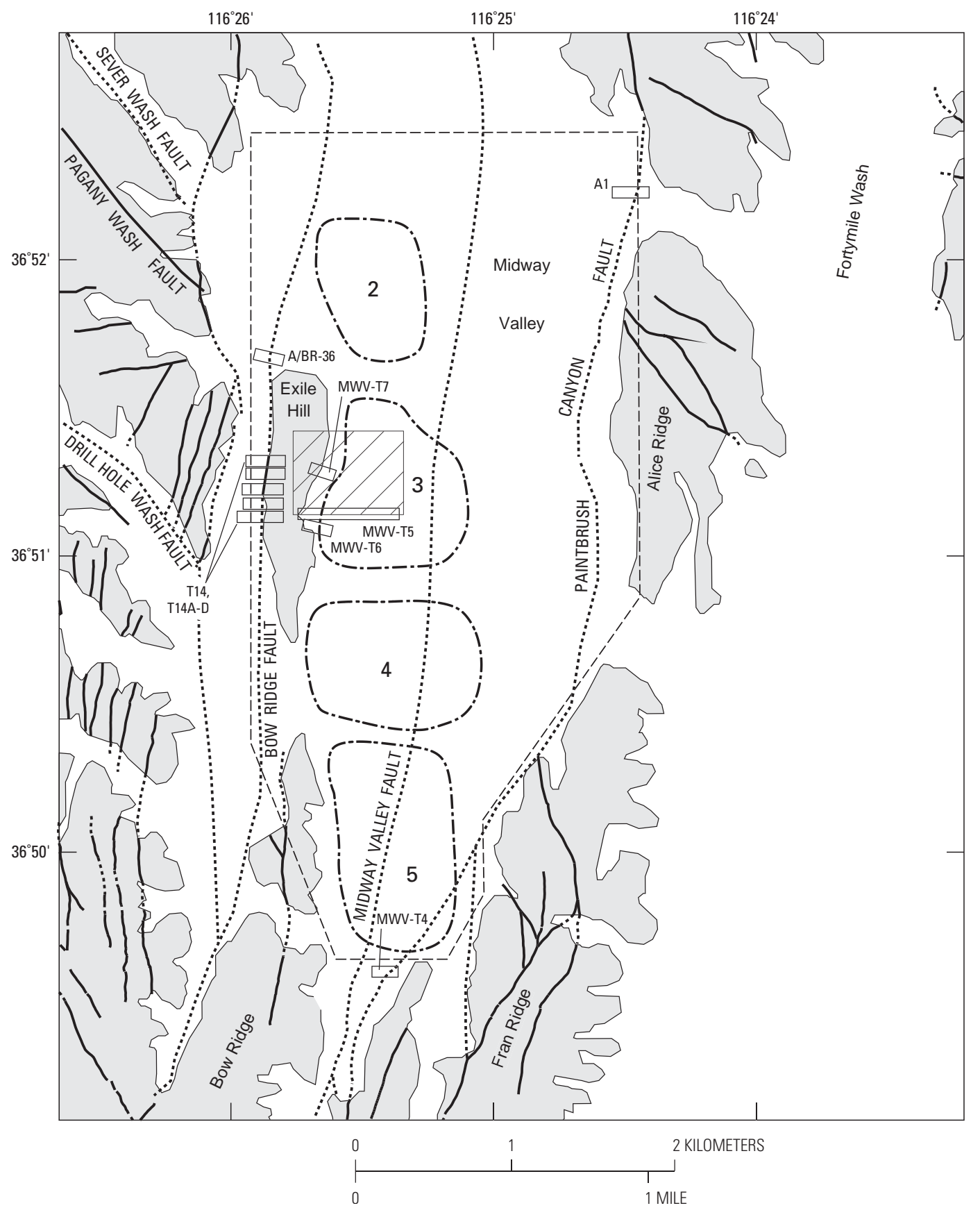

EXPLANATION

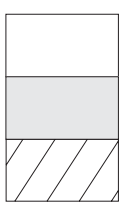

Quaternary surficial deposits

- - - .- Faults, dashed where inferred, dotted where concealed [adapted from Scott and Bonk (1984) and Day and others (1998)]

Tertiary volcanic bedrock

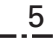

Prospective surface facilities site

- $\mathbf{5}$ - - Boundary of candidate sites and site number proposed by Neal (1985)

MWV-T4 Area of detailed Quaternary mapping (Wesling and others, 1992) Trench location and name (size is exaggerated)

Figure 2. Midway Valley, Nevada, showing four of six sites for the prospective repository surface facilities site (Neal, 1985), the area of detailed Quaternary mapping (Wesling and others, 1992), soil-stratigraphic studies, and the locations of detailed trenching investigations. Area 3 is the Reference Conceptual Site (RCS). 
Evaluation of Location, Recency of Faulting Near Prospective Surface Facilities in Midway Valley, Nye Co., Nevada

Field investigations and related studies in Midway Valley were done primarily from 1991 to 1994 , when the principal source of available data on the stratigraphy and structure of the Miocene volcanic rocks in the Yucca Mountain area was the geologic mapping of Scott and Bonk (1984). Accordingly, stratigraphic names for various bedrock units (mainly within the Tiva Canyon Tuff) shown on several of the maps, geologic sections, and trench logs that were prepared for this report follow Scott and Bonk's (1984) terminology. Faults shown on several of these illustrations also follow those of Scott and Bonk (1984), as specifically indicated in figure and plate captions and explanations.

Subsequent stratigraphic studies (Sawyer and others, 1994; Buesch and others, 1996) and geologic mapping (Day and others, 1998) of the Miocene volcanic sequence have led to a revised stratigraphic nomenclature and a fault distribution pattern that now are applied commonly in the Yucca Mountain area. Appropriate references to these later publications will be made as they are pertinent to the discussions being presented. However, it is important to recognize that the main emphasis of this report is on Quaternary stratigraphy and history of fault activity and that relations and interpretations regarding these subjects have not been substantially altered by subsequent investigations.

Support for the Midway Valley study was provided by the U.S. Department of Energy through the U.S. Geological Survey (contract no. 134-93-C-4076), Sandia National Laboratories (contract no. 75-4350), and Science Applications Inter- national Corporation (contract nos. 45-9305-47-76/01-1049-

33-4600-216-7209 and 01-1049-33-5600-216-7209).

\section{Purpose and Scope}

The purpose of this report is to present the results of investigations to characterize the surficial deposits and Quaternary faulting activity in Midway Valley, which lies adjacent to, and east of, Yucca Mountain. The surficial geology was mapped at a scale of 1:6,000, and the map was published as part of an earlier report by Wesling and others (1992). An integral part of the surficial geology studies was the siting and excavation (or reexcavation) of five trenches-MWV-T4, -T5, -T6, -T7, and A/BR-3 (fig. 1) -for which detailed maps and descriptions of the exposed surficial profiles were made to characterize the soils and other deposits that are associated with Quaternary units mapped at the surface, to facilitate correlation of the various units across the study area, and to determine the extent to which surficial deposits were disturbed by Quaternary fault activity.

Three of the trenches (MWV-T5, -T6, -T7) were sited specifically to provide the stratigraphic and structural data needed to assess the potential for surface fault rupture at the locality of the prospective surface facilities in the western part of the RCS (figs. 1, 3, 4; pls. 1 and 2).

In addition to the trenches, 33 soil test pits were excavated as part of the present study, and an equal number were

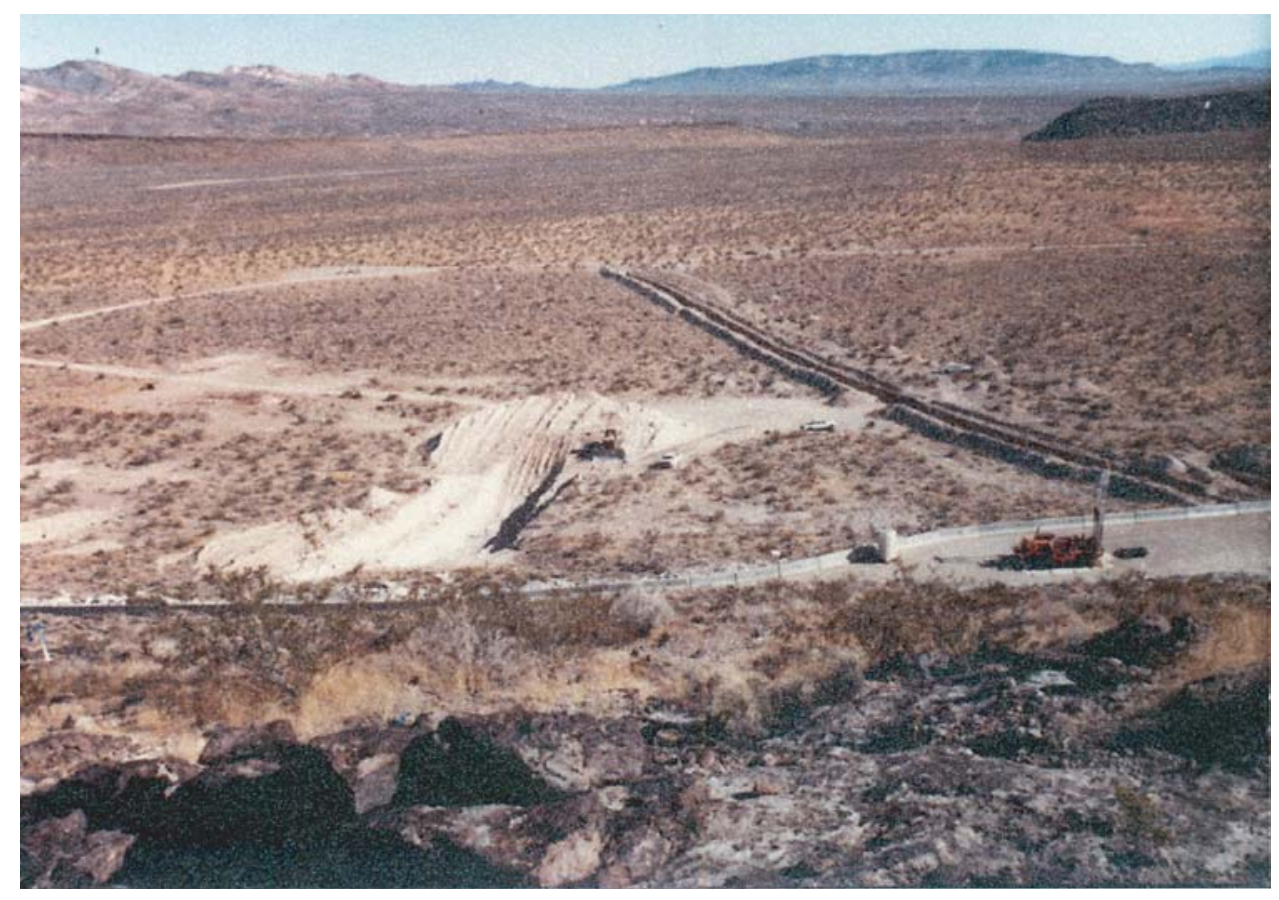

Figure 3. View southeast from Exile Hill showing locations of trench MWV-T5 (long excavation on the right) and trench MWV-T7 (wide trench on the left) on the west side of Midway Valley. (Photograph by Johnson Controls, 1994.) 


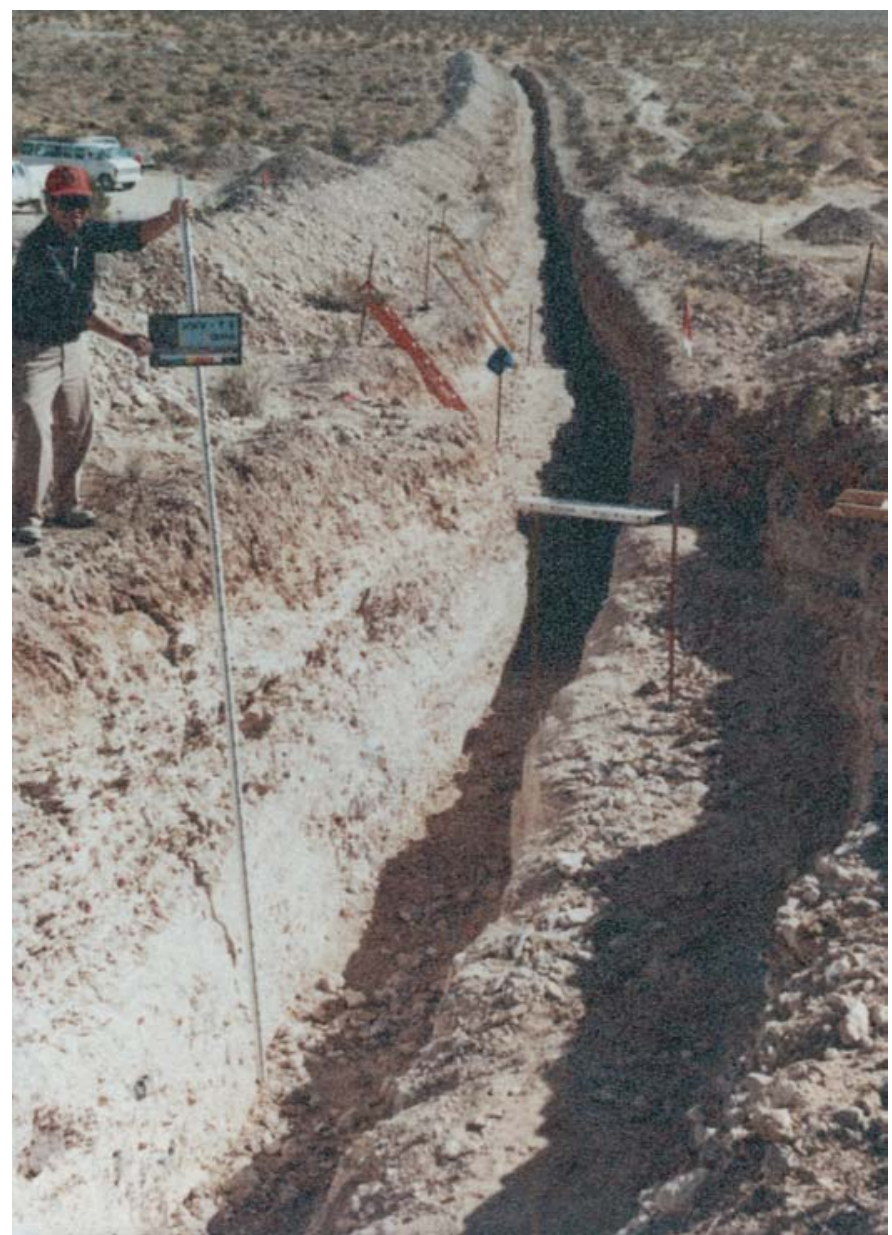

Figure 4. Trench MWV-T5 (west to east), a 340-m-long, 3-m-deep excavation providing a continuous exposure of the Quaternary colluvial and alluvial deposits across the prospective surface facilities site on the west side of Midway Valley. (Photograph by Johnson Controls, 1994.)

excavated as part of a related site-characterization project to study and analyze soil and rock properties in areas most likely to be considered for the construction of prospective surface facilities. Detailed descriptions of the surficial deposits exposed in 29 of the soil pits are given in tables A1 and A2 of the Appendix at the end of this report, and locations are shown in figure A1. Three other soil pits (TP-7, TP-8, TP-32; locations shown on plate 2) were mapped because they exposed fractures in the Quaternary sediments (discussed in the section "Exile Hill Fault").

The bedrock geology of Exile Hill, a low ridge along the west side of Midway Valley, also was mapped at a scale of 1:6,000 to locate and characterize faults that displace Tertiary bedrock (pl. 1). A primary objective of the bedrock mapping was to identify any east-west- or northwest-trending faults, which are of particular concern because faults of that trend have been mapped on Yucca Mountain, and two of them, the
Sever Wash and Pagany Wash faults, trend toward the RCS (Day and others, 1998). Three new minor faults were identified during the course of this mapping: (1) the north- to northeasttrending Exile Hill fault located along the eastern base of Exile Hill; and (2) two north- to northwest-trending faults, the East Portal and West Portal faults that are exposed on Exile Hill and in the excavation at the North Portal of the Exploratory Studies Facility (ESF), which is located at the site of borehole NRG-1 (pl. 1).

Studies to determine the location and extent of faulting in bedrock beneath the surficial deposits of Midway Valley benefited from the following sources of information:

1. A variety of geophysical surveys (pl. 3) including (a) electrical resistivity (Senterfit and others, 1982; U.S. Geological Survey, 1984); (b) seismic reflection and refraction (Reynolds and Associates, 1985; Neal, 1986); and (c) gravity and ground magnetic data (Ponce, 1993; Ponce and Langenheim, 1994).

2. Data from boreholes, some 10 of which were drilled in the immediate vicinity of Exile Hill (those labeled "NRG" and "RF" on plate 1) and others in the surrounding area (see figure A1 in Appendix).

In addition to the trench studies completed during this investigation, six other trenches were excavated and mapped in the vicinity of Midway Valley to determine the nature of Quaternary activity on the two major normal faults bounding the structural block that forms the valley. Five trenches spanning the Bow Ridge fault on the west side of Exile Hill (14, 14A-D, fig. 1, pl. 2) were studied by Taylor and Huckins (1986) and Menges and others (1993, 1994, 1997). Trench A1, excavated across the northern projection of the Paintbrush Canyon fault north of Alice Ridge (fig. 1), first was described by Swadley and others (1984), and later by C.M. Menges (written commun., 1995).

\section{Acknowledgments}

The following people, listed in alphabetical order, participated in technical discussions and (or) technical reviews during the various planning and implementation phases for this study (affiliation noted if other than U.S. Geological Survey): Clarence Allen (California Institute of Technology), Steve Beason (U.S. Bureau of Reclamation), Thomas Bullard (Geomatrix Consultants, Inc.), Wilfred Carr, Jeffrey Coe, Mike Fahy, Charles Harrington (Los Alamos National Laboratory), Philip Justus (Nuclear Regulatory Commission), William Keefer, Ralph Klinger (U.S. Bureau of Reclamation), Les McFadden (University of New Mexico), Keith McConnell (Nuclear Regulatory Commission), Chris Menges, Dennis O'Leary, Howard Oliver, John Oswald, Lucy Piety (U.S. Bureau of Reclamation), Silvio Pezzopane, David Ponce, Daniel Ponti, Leon Reiter (Nuclear Waste Technical Review Board), David Schwartz, Bill Simonds, Kent Snyder (Lockheed-Martin Corp.), Timothy Sullivan (U.S. Department of Energy), Emily Taylor, and Giovanni Vadurro. 


\section{Geologic Setting}

\section{Physiography}

Midway Valley is located at the eastern margin of Yucca Mountain, a dissected volcanic plateau that lies within the southern Great Basin part of the Basin and Range physiographic province. The mountain's maximum altitude is about 2,040 meters (m) to the northwest of Midway Valley. Directly to the west, the crest of Yucca Mountain is at 1,475 to 1,750 $\mathrm{m}$ in altitude and slopes gently to the east and south. Altitudes of the valley floor range from about 1,070 $\mathrm{m}$ at its low point between Alice and Fran Ridges to the east, to about 1,220 $\mathrm{m}$ in the northwestern part of the valley. Drainages heading in Drill Hole, Pagany, Sever, and Yucca Washes to the west and northwest along the east slope of Yucca Mountain flow eastward across Midway Valley into Fortymile Wash (fig. 1).

\section{Bedrock Stratigraphy}

The Yucca Mountain-Midway Valley area lies within the middle Miocene southwestern Nevada volcanic field, a multicaldera silicic volcanic field in the southern Great Basin (fig. 5) (Sawyer and others, 1994). Most of the deposits within this field issued from a group of nested and overlapping calderas known as the Timber Mountain-Oasis Valley caldera complex (fig. 5) (Byers and others, 1976). The rocks in the vicinity of Yucca Mountain consist mostly of pyroclastic flow and fallout tephra deposits with minor lava flows that overlie deeply buried Paleozoic sedimentary strata along a pronounced regional unconformity. The volcanic sequence, with aggregate thicknesses commonly ranging from 1,000 to $3,000 \mathrm{~m}$, has been formally subdivided into groups and formations; the principal stratigraphic units are listed in table 1 . Formations have been further subdivided into members and smaller units based on differences in physical properties and geochemical and mineralogic compositions between successive cooling units (Buesch and others, 1996; Moyer and Geslin, 1995; Geslin and others, 1995; Geslin and Moyer, 1995). Establishing this hierarchy of stratigraphic subdivisions has made possible a geologic mapping program of sufficient detail to define faults in bedrock that have as little as a few meters of displacement (for example, see Day and others, 1998).

The Tiva Canyon Tuff is the most widely exposed bedrock unit around the margins of Midway Valley (Scott and Bonk, 1984; Day and others, 1998). Limited outcrops of the Topopah Spring and Pah Canyon Tuffs occur in the southern part of Fran Ridge and in highlands north of Alice Ridge (fig. 1). Rhyolite lava flows and ash-flow tuffs assigned to the uppermost part of the Paintbrush Group (post-Tiva Canyon Tuff) form prominent ridges at the north end of the valley. A small outcrop of the Rainier Mesa Tuff was mapped during the present study on the west side of Exile Hill (pl. 1).

As indicated earlier, the subdivisions and terminology
Table 1. Principal stratigraphic units exposed (except as noted) in the Yucca Mountain area, Nevada.

[Based on Sawyer and others (1994). Ma, millions of years before present]

\begin{tabular}{ll}
\hline Geologic name & $\begin{array}{c}\text { Age } \\
\text { (Ma) }\end{array}$ \\
\hline $\begin{array}{l}\text { Timber Mountain Group } \\
\text { Ammonia Tanks Tuff (not exposed) }\end{array}$ & 11.45 \\
$\quad$ Rainier Mesa Tuff & 11.6 \\
Paintbrush Group & \\
$\quad$ Tiva Canyon Tuff & 12.7 \\
$\quad$ Yucca Mountain Tuff & \\
$\quad$ Pah Canyon Tuff & \\
$\quad$ Topopah Spring Tuff & 12.8 \\
Calico Hills Formation & 12.9 \\
Crater Flat Group & \\
$\quad$ Prow Pass Tuff & \\
$\quad$ Bullfrog Tuff & 13.25 \\
$\quad$ Tram Tuff (not exposed) & \\
\hline
\end{tabular}

established by Buesch and others (1996) for the Tiva Canyon Tuff are now in common use in the Yucca Mountain area. Correlation of the units mapped by Scott and Bonk (1984), and shown on various illustrations in this report (for example, plate 1), with the terminology of Buesch and others (1996) is as follows (Scott and Bonk's unit names in quotes): "caprock" and "upper cliff" units form the crystal-rich member of the Tiva Canyon Tuff, and the "upper lithophysal," "rounded-step," and "lower lithophysal" units compose the crystal-poor member.

\section{General Bedrock Structure}

Yucca Mountain and Midway Valley are situated within the Walker Lane Belt (fig. 5), a major northwest-trending zone of discontinuous strike-slip faults and extensional deformation that separates a regime of right-lateral transpression to the west and south from a regime of crustal extension in the Basin and Range Province to the north and east (Stewart, 1980, 1988, 1992; Carr, 1984).

Post-Miocene deformation within the Walker Lane Belt in the Yucca Mountain and adjacent areas is characterized by three principal types of faults (fig. 5): (1) north- to northeast-trending normal faults (for example, Paintbrush Canyon fault); (2) northwest-trending, right-lateral strike-slip faults (for example, Furnace Creek fault zone); and (3) northeast-trending, left-lateral strike-slip faults (for example, Spotted Range-Mine Mountain shear zone). North- to northeasttrending normal faults and the intervening elongate eastward- 


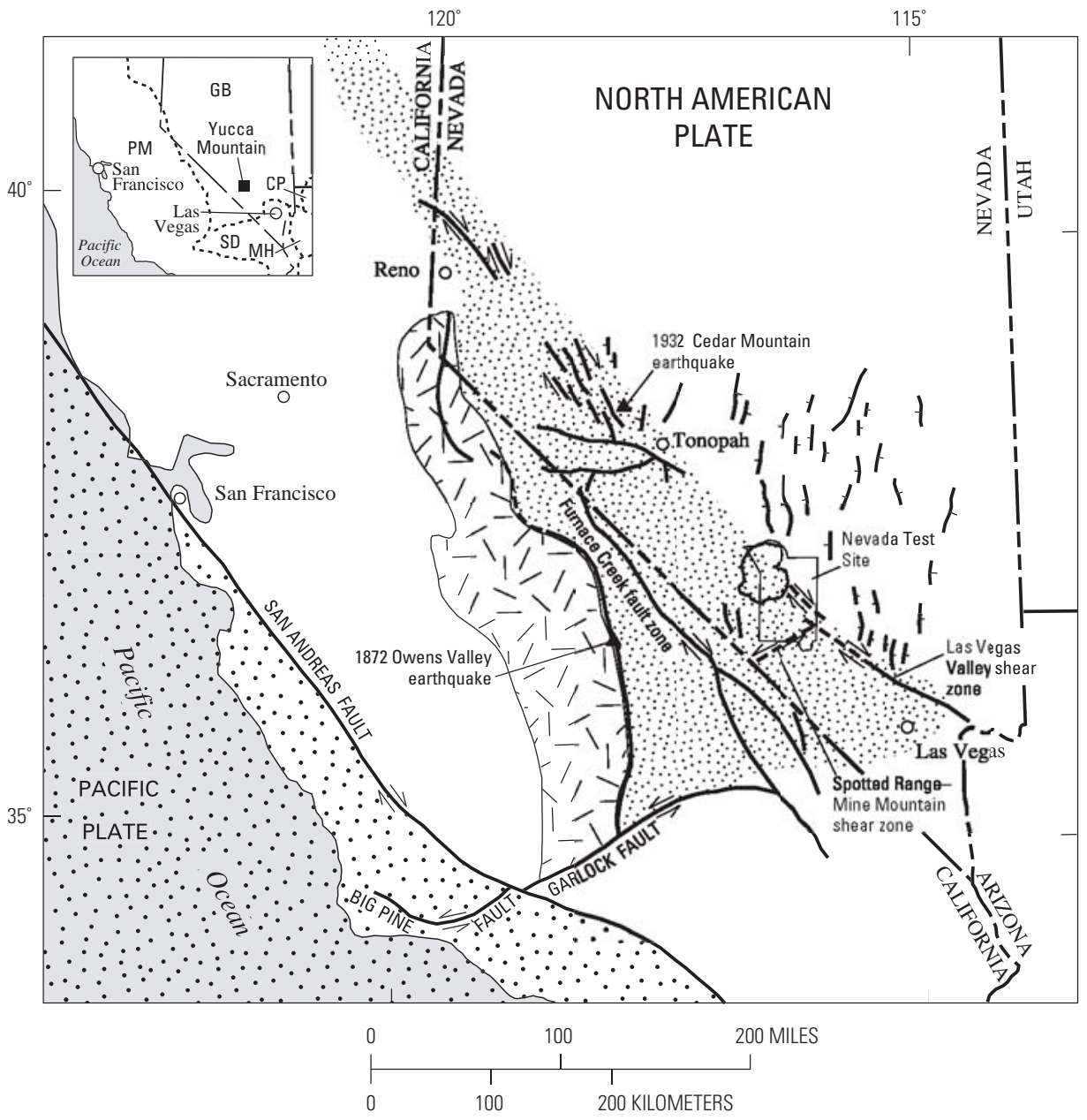

EXPLANATION

\begin{tabular}{rl|l}
\hline$\because \because \because \because$ & Pacific plate \\
\hdashline$-1 / \frac{1}{1}$ & North American plate \\
\hdashline & Batholith \\
\hdashline & Walker Lane Belt
\end{tabular}

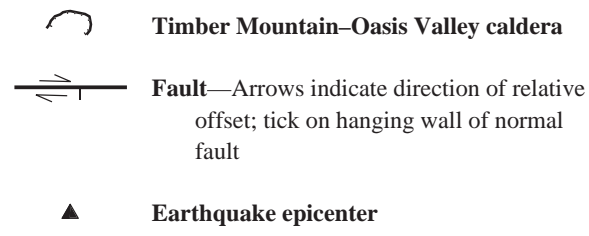

Figure 5. Regional tectonic setting of Yucca Mountain (modified from U.S. Department of Energy, 1988). Inset map (in upper left corner) shows physiographic boundaries within the area of the figure. Abbreviations: $\mathrm{CP}$, Colorado Plateau; GB, Great Basin section of Basin and Range; LV, Las Vegas, Nevada; MH, Mexican Highlands Section of Basin and Range; PM, Pacific Mountains System; SF, San Francisco, California; SD, Sonoran Desert section of Basin and Range Province.

tilted fault blocks bounded by them dominate the structure of Yucca Mountain and Midway Valley. The major faults are spaced approximately $1-4 \mathrm{~km}$ apart and generally dip steeply toward the west, with hundreds of meters of down-to-the-west displacement of bedrock (Scott and Bonk, 1984; Day and others, 1998). The Bow Ridge and Paintbrush Canyon faults that bound Midway Valley are two of these prominent faults (fig. 1), and the valley itself forms an east-dipping half-graben between the faults. Subsidiary structures include north-trending normal faults and northwest-trending strike- or oblique-slip faults that cause small displacements of bedrock between the block-bounding faults (Scott and Bonk, 1984; Day and others, 1998). A detailed discussion of geologic structures is given in section "Faulting in the Midway Valley Area." 


\section{Quaternary Geology}

Early work in the Yucca Mountain-Midway Valley region differentiated three major late Cenozoic stratigraphic units based on "correlation characteristics" (Hoover and Morrison, 1980; Hoover and others, 1981; Swadley and others, 1984; Hoover, 1989). The concept of "correlation characteristics" utilizes physical and morphologic characteristics of landscape elements, including landform, drainage network, soils (the presence or absence of the Av horizon), topographic position, desert pavement, desert varnish, depositional environment, and lithology. According to these studies, the oldest surficial unit, QTa, is Quaternary (early Pleistocene) or Tertiary in age or both. Units Q2 and Q1 represent middle to upper Pleistocene and Holocene deposits, respectively. Each major geologic unit of Hoover and others (1981) is divided into several subunits; for example, 10 subunits of Q1 and Q2 are mapped in the region. Swadley and others (1984) mapped the major late Cenozoic stratigraphic units in Midway Valley, but no detailed surficial geologic mapping that subdivided these units for the valley had been presented until Taylor (1986) mapped the fluvial terrace sequence along Yucca and Fortymile Washes, including a small area in the northernmost part of the valley.

Taylor (1986) distinguished and mapped six geologic units of Tertiary to Quaternary age and described pedogenic soil profiles to (1) assess the effect of time and climate on soil development, and (2) quantify the variability in past Quaternary climates by modeling the degree of development of the calcic horizon. The ages of map units were assigned based on an inferred correlation with the stratigraphy and numerical dates of Hoover and others (1981), Szabo and others (1981), and Swadley and Hoover (1983). Taylor (1986) demonstrated that age correlates with soil morphology and the progressive accumulation of secondary carbonate, clay, and silica. Calcium carbonate, calcium-magnesium carbonate, and other carbonate species in soils were not distinguished. The term "carbonate" is used in this report to refer to all pedogenic carbonate species. The term "silica" is used to refer to pedogenic silica species, which Taylor (1986) showed to be predominately opal-CT. Taylor's work clearly demonstrated the usefulness of detailed soil studies for stratigraphic correlations and the estimation of the age of surficial units within the Yucca Mountain area.

Alluvial deposits and overlying geomorphic surfaces in the valley were mapped at a scale of 1:6,000 by Wesling and others (1992); the part of their map covering the immediate area of the RCS is shown in figure 6. An alluvial geomorphic surface is analogous to an allostratigraphic unit, which is a mappable stratiform body that is defined and delineated on the basis of its bounding discontinuities (North American Commission on Stratigraphic Nomenclature, 1983). Primary characteristics used to assess the relative stratigraphic ages of the map units include stratigraphic and geomorphic position, degree of desert pavement development, amount and degree of desert varnish accumulation, degree of preservation of original bar-and-swale topography, and degree of soil-profile development.

\section{Quaternary Deposits, Soils, and Geomorphic Surfaces}

Surficial deposits in the Midway Valley area include (1) alluvium that underlies alluvial fan and fluvial terrace surfaces and is deposited along active washes; (2) colluvium and debris-flow deposits that occur along the base and mantle the lower parts of the hillslopes that bound the valley; (3) areas of mixed bedrock and thin colluvium; and (4) eolian deposits. The alluvial sequence is subdivided into eight informal allostratigraphic units designated as QT0 at the base and numbered consecutively from Qa1 to Qa7 in ascending order (fig. 7); correlative colluvial units are numbered Qc1, Qc2, and so forth. The total combined thickness of these deposits in the valley is unknown, but borehole data indicate that locally the thickness is as much as $45 \mathrm{~m}$ (Carr, 1992).

The informal allostratigraphic units have age-dependent surface properties that reflect interactions and feedback mechanisms among soil development, eolian deposition, clast weathering, desert varnish accumulation, biological activity, and progressive erosional instability. Younger units (Qa5-Qa7) exhibit relatively unaltered original surface characteristics, including incipient to weak soil development, little or no desert varnish accumulation or desert pavement development, relatively unaltered bar-and-swale relief, and minimal eolian accumulations in the upper parts of soil profiles. Older units (Qa2-Qa4) have more strongly developed desert pavement, more continuously and darkly varnished clasts, greatly reduced bar-and-swale relief, strongly developed soils, and relatively thick accumulations of silt and fine sand in the upper parts of soil profiles. The oldest units (QT0 and Qa1) have degraded surface characteristics and soil profiles reflecting erosional modification of geomorphic surfaces.

The relative ages of the deposits, soils, and geomorphic surfaces in Midway Valley are well established, but there is only limited direct numerical age control. Most numerical ages are derived from colluvium in trenches dug to evaluate fault activity on the major faults along the margins of the valley. Despite the age uncertainties, Qa3 and older units are sufficiently old to assess, with a high degree of confidence, whether or not there are significant Quaternary faults in Midway Valley in general and at the prospective surface facility site in particular.

Available numerical age control (table 2), relative-age data (table 3), and regional soil-stratigraphic correlations (table 4) were used to assign ages to map units. Establishing exact numerical ages of surficial units in arid environments is difficult because of the time-transgressive nature of fluvial deposition and geomorphic surface development, the paucity of suitable materials for dating, and the imprecise nature of dating complex geomorphic and pedogenic systems based 


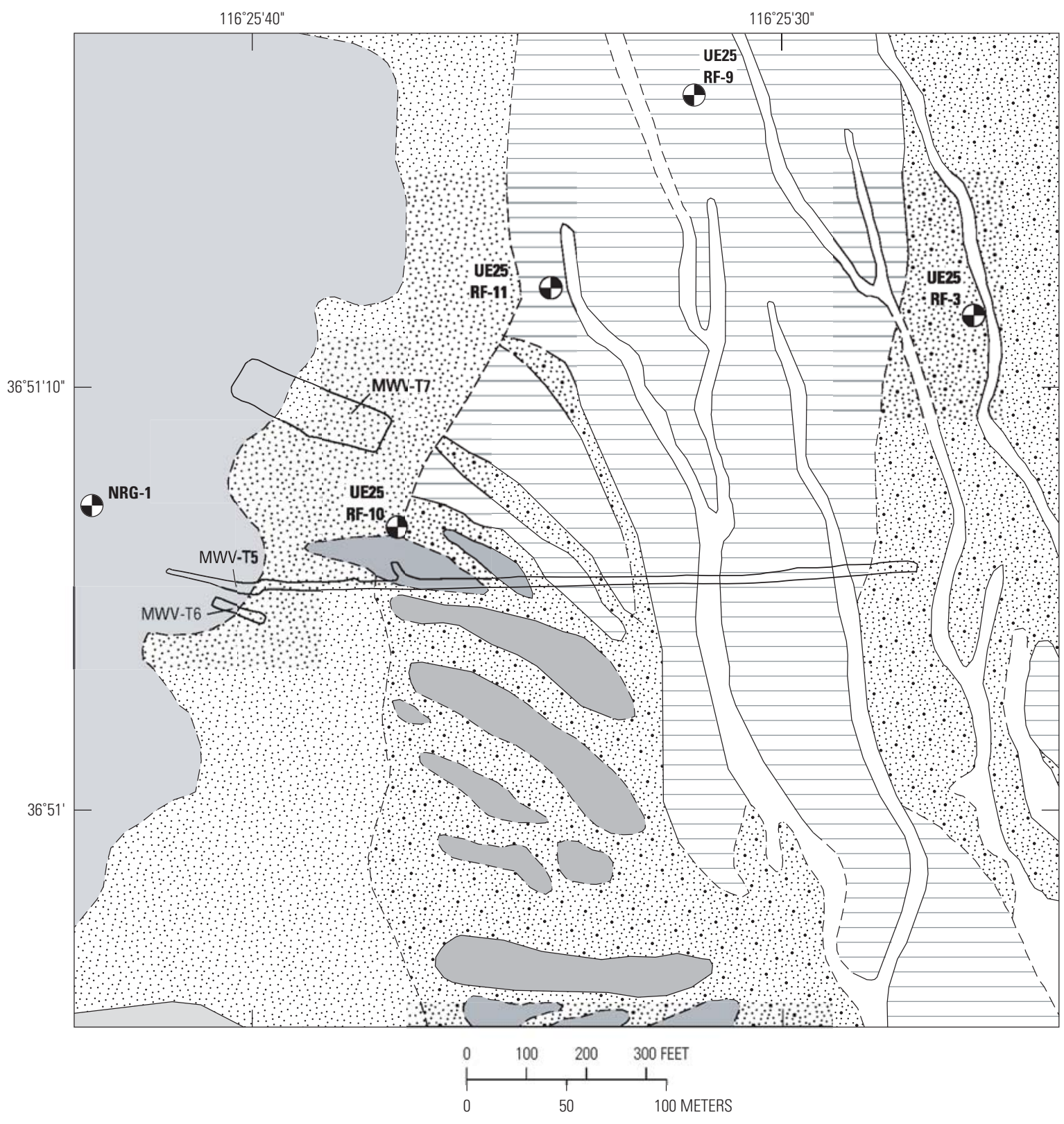

EXPLANATION

Note: See text for unit descriptions

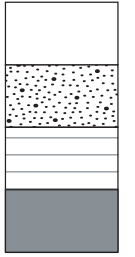

Historic and middle to late Holocene-Qa7 + Qa6

Latest Pleistocene to Holocene-Qa5

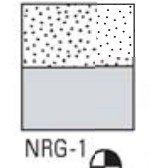

Early to late Quaternary-Qcu

Tertiary volcanic bedrock and Qcu colluvium

Middle to late Pleistocene-Qa4 + Qa3

-1 Borehole location and descriptor

Middle to late Pleistocene-Qa3

MWV-T6

Trench location and descriptor

Figure 6. Surficial geology and trench, borehole, and soil-pit locations in the vicinity of the prospective surface facilities site in Midway Valley. Geology from Wesling and others (1992). 


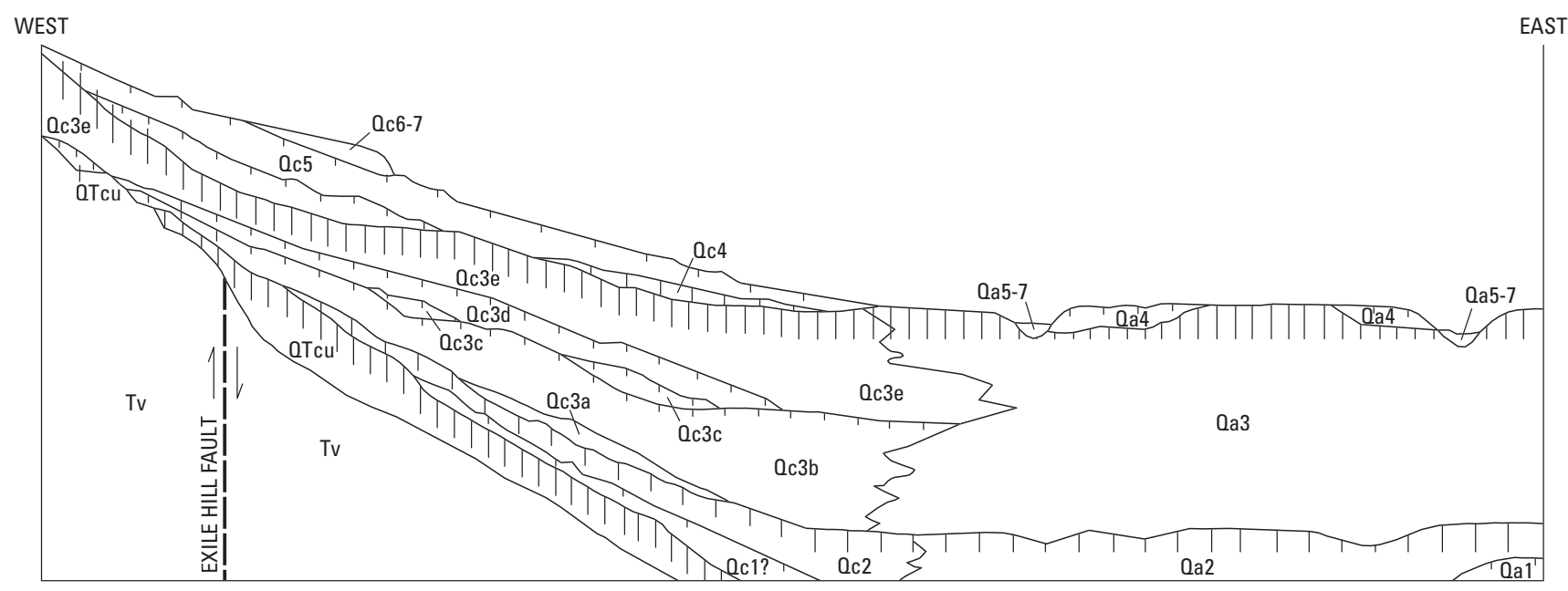

Not to scale

\section{EXPLANATION}

\begin{tabular}{|c|c|}
\hline $\begin{array}{l}\text { Qa5-7/ } \\
\text { Oc6-7 }\end{array}$ & Latest Pleistocene to historic alluvium/colluvium \\
\hline 0c5 & Latest Pleistocene to early Holocene colluvium \\
\hline $\begin{array}{l}\mathrm{Oa} 4 / \\
\mathrm{Oc4}\end{array}$ & Late Pleistocene alluvium (Qa4) and colluvium (Qc4) \\
\hline $\begin{array}{c}0 \text { a3/ } \\
\text { 0c3a-e }\end{array}$ & Middle to late Pleistocene alluvium (Qa3) and colluvium (Qc3a-e) \\
\hline $\begin{array}{l}\mathrm{Oa} 2 / \\
\mathrm{Oc} 2\end{array}$ & Middle Pleistocene alluvium (Qa2) and colluvium (Qc2) \\
\hline $\begin{array}{l}\text { Oa1/ } \\
\text { Oc1 }\end{array}$ & Early to middle Pleistocene alluvium (Qa1) and colluvium (Qc1) \\
\hline
\end{tabular}

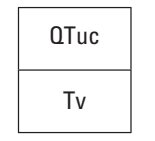

Tertiary to early Pleistocene colluvium

Miocene Tiva Canyon Tuff of the Paintbrush Group

Tा IाTा T Geologic contact,-—Vertical tick marks indicate soils developed in units; longer, more closely spaced tick marks indicate stronger soil profile development

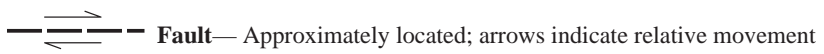

Note: This reflects the stratigraphy across an approximately 340-m-long, west-to-east transect based on data from trenches MWV-T5, MWV-T6, and MWV-T7

Figure 7. Schematic section showing stratigraphic relations among bedrock, colluvium, and alluvium at the prospective surface facilities site in Midway Valley.

on available dating methodologies (uranium-series (U-series) dating of pedogenic carbonate and thermoluminescence (TL) dating of the silt-size fraction of eolian and fluvial sediments) (table 2). Assuming exposure to sunlight and complete draining of the thermoluminescence signal of the sediments at the time of deposition, TL dates will provide a reliable age of the deposit, although a number of factors, such as uncertainties in the average radiation dose rate since the sample was deposited, incomplete draining of the signal at the time of deposition, or subsequent infiltration of fines, may cause unreliable results. Most problems, however, can be mitigated through careful sample selection and analysis. In comparison, U-series dates provide ages for the formation of secondary minerals (primarily calcium carbonate) that accumulated in the sediments after they were deposited. It may take tens of thousands of years before enough carbonate accumulates to produce a collectable sample. Accumulation of secondary minerals commonly occurs over long periods of time and can continue even after a deposit is buried by younger sediments. An individual sample is likely to include both old and young carbonate, and the resulting age will be intermediate between the two end members. Depending on the part of the soil profile that is sampled, one may obtain very different ages from the same sedimentary deposit. It is not uncommon for $\mathrm{U}$-series ages from a given stratigraphic sequence to appear stratigraphically inconsistent. Despite these inconsistencies, U-series dates generally represent a minimum age for a Quaternary deposit. Where samples from the same stratigraphic horizon yield divergent ages, the age of the deposit can be inferred to be older than the oldest date obtained from that horizon (assuming that care was taken to avoid collecting samples containing carbonate reworked from an older horizon).

The presence of Bishop tephra, dated as approximately 760 ka (Sarna-Wojcicki and others, 1993), and minor late Pleistocene basaltic ashes in Quaternary sediments of the Yucca Mountain region (for example, Lathrop Wells volcanic center ashes dated as $77 \pm 6$ ka by Heizler and others, 1999) potentially can help to constrain numerical ages. However, the usefulness of the basaltic ashes may be limited because of extensive reworking of the tephras at some localities. Correlations to other desert soil chronosequences based on soilstratigraphic studies is another important technique for estimating the ages of surficial units, but quantitative soil-chemistry and particle-size data are presently unavailable to rigorously assess numerical ages. 
Table 2. Summary of numerical ages of Quaternary deposits in Midway Valley. ${ }^{1}$

[USGS, U.S. Geological Survey; TL, thermoluminescence; U, uranium-series disequlibrium; ka, thousands of years before present]

\begin{tabular}{|c|c|c|c|c|}
\hline $\begin{array}{l}\text { Sample number } \\
\text { (USGS laboratory number) }\end{array}$ & Dating method & Material sampled & Stratigraphic unit ${ }^{2}$ & Age (ka) \\
\hline \multicolumn{5}{|c|}{ Trench MWV-T4 (plate 5) } \\
\hline $\begin{array}{l}\text { MWV-T4-03 } \\
\text { (TL-05) }\end{array}$ & TL & surface Av horizon & IX & $6 \pm 1$ \\
\hline $\begin{array}{l}\text { MWV-T4-02 } \\
\text { (TL-04) }\end{array}$ & TL & eolian sand & VIII & $38 \pm 6$ \\
\hline $\begin{array}{l}\text { MWV-T4-01 } \\
\text { (TL-03) }\end{array}$ & TL & eolian sand & VII & $73 \pm 9$ \\
\hline $\begin{array}{l}\text { MWV-T4-04 } \\
\text { (HD-1373) }\end{array}$ & $\mathrm{U}$ & $\begin{array}{l}\text { carbonate rhyzolith } \\
\text { carbonate rhyzolith }\end{array}$ & $\mathrm{VI}_{1}$ & $\begin{array}{l}133 \pm 5 \\
140 \pm 5\end{array}$ \\
\hline $\begin{array}{l}\text { MWV-T4-05 } \\
\text { (HD-1372) }\end{array}$ & $\mathrm{U}$ & $\begin{array}{l}\text { carbonate rhyzolith } \\
\text { carbonate rhyzolith }\end{array}$ & $\mathrm{VI}_{1}$ & $\begin{array}{l}119 \pm 2 \\
131 \pm 3\end{array}$ \\
\hline $\begin{array}{c}\text { MWV-T4-06 } \\
\text { (HD-1371) }\end{array}$ & $\mathrm{U}$ & $\begin{array}{l}\text { carbonate rhyzolith } \\
\text { carbonate rhyzolith } \\
\text { carbonate rhyzolith }\end{array}$ & $\mathrm{VI}_{1}$ & $\begin{array}{l}44.0 \pm 0.5 \\
55.0 \pm 0.5 \\
63.0 \pm 1.6\end{array}$ \\
\hline $\begin{array}{l}\text { MWV-T4-07 } \\
\text { (HD-1370) }\end{array}$ & $\mathrm{U}$ & $\begin{array}{l}\text { silica-rich stringer in carbonate } \\
\text { layer }\end{array}$ & $\mathrm{V}$ & $\begin{array}{l}383 \pm 24 \\
423 \pm 44\end{array}$ \\
\hline $\begin{array}{l}\text { MWV-T4-08 } \\
\text { (HD-1368) }\end{array}$ & $\mathrm{U}$ & carbonate-rich fine-rhyzolith mass & II & $232 \pm 15$ \\
\hline $\begin{array}{c}\text { MWV-T4-09 } \\
\text { (HD-1368) }\end{array}$ & $\mathrm{U}$ & carbonate-rich fine-rhyzolith mass & II & $344 \pm 35$ \\
\hline $\begin{array}{c}\text { MWV-T4-11 } \\
\text { (HD-1589) }\end{array}$ & $\mathrm{U}$ & $\begin{array}{l}\text { steeply dipping stringer of } \\
\text { carbonate and silica }\end{array}$ & Ia & $600 \pm \infty / 170^{3}$ \\
\hline \multicolumn{5}{|c|}{ Trench MWV-T5 (plate 4) } \\
\hline $\begin{array}{l}\text { MWV-T5-01 } \\
\text { (TL-01) }\end{array}$ & TL & buried Av horizon & $\mathrm{Qc}^{4}$ & $27 \pm 5$ \\
\hline $\begin{array}{c}\text { MWV-T5-02 } \\
\text { (HD-972) }\end{array}$ & $\mathrm{U}$ & top of ooid-rich platy $\mathrm{K}$ horizon & $Q c 3 e^{4}$ & $41 \pm 8$ \\
\hline \multicolumn{5}{|c|}{ Trench MWV-T7 (plate 6) } \\
\hline $\begin{array}{l}\text { MWV-T7-04 } \\
\text { (HD-1083) }\end{array}$ & $\mathrm{U}$ & carbonate rhyzoliths & $\mathrm{Qc} 2^{4}$ & $670 \pm 150 / 90^{5}$ \\
\hline
\end{tabular}

\footnotetext{
${ }^{1}$ Age data from J.B. Paces (written commun., 1995); ages given with uncertainty ( \pm ) at the 95 percent confidence level.

${ }^{2}$ Roman numerals refer to units defined in trenches.

${ }^{3}$ Based on estimated original ${ }^{234} \mathrm{U} /{ }^{238} \mathrm{U}$ values, this sample is probably much older than 350 ka; the numerical age may exceed $600 \mathrm{ka}$.

${ }^{4}$ See figure 7 for stratigraphic position.

${ }^{5}$ Based on estimated original ${ }^{234} \mathrm{U} /{ }^{238} \mathrm{U}$ values, this sample is probably much older than $350 \mathrm{ka}$; the numerical age may exceed approximately $700 \mathrm{ka}$.
}

Based on considerations discussed above, a multipleparameter dating approach was used to estimate the ages of surficial units in Midway Valley. Ages of the principal alluvial units, based on TL and U-series dates, tephrochronology, and correlations of soils to other desert chronosequences, are: Qa7, latest Holocene to historic; Qa6, middle to late Holocene to historic; Qa5, late Pleistocene to middle Holocene; Qa4, late Pleistocene; Qa3, middle to late Pleistocene; Qa2, middle Pleistocene; Qa1, early to middle Pleistocene; and QT0, Pliocene to early Pleistocene(?). The approximate numerical ages for these subdivisions of the Tertiary and Quaternary Epochs are shown in table 5.

\section{Alluvial Deposits and Geomorphic Surfaces}

Geomorphic surfaces form the bulk of Quaternary features in Midway Valley. Deposits associated with these surfaces include alluvium, and minor eolian and debris-flow sediments. Sedimentologic properties of the various alluvial units are closely similar. In general, fluvial deposits are predominately sandy gravel with interbedded gravelly sand and sand. Fluvial facies present in these deposits include relatively coarse grained channel bars and intervening finer grained swales. The grain size of the bars and swales is dependent on their position within the landscape (proximal or distal fan region) and the sediment source. In the proximal alluvial fan 
Table 3. Summary of diagnostic surface and soil properties of Quaternary map units in Midway Valley.

[Abbreviations for soil structure: sg, single grained; m, massive; 1, weak; 2, moderate; 3, strong; vf, very fine; f, fine; m, medium; pl, platy; sbk, subangular blocky. Abbreviations for clay films: N.P., not present; 1, few; 2, common; 3, many; n, thin; mk, moderately thick; pf, ped face; co, colloidal stains. Abbreviation for maximum carbonate stage: N.P., not present. est., estimate]

\begin{tabular}{|c|c|c|c|c|c|c|c|c|c|}
\hline \multirow[b]{2}{*}{ Map unit } & \multicolumn{4}{|c|}{ Surface characteristics ${ }^{1}$} & \multicolumn{5}{|c|}{ Soil characteristics } \\
\hline & $\begin{array}{c}\text { Desert } \\
\text { pavement }^{2}\end{array}$ & $\begin{array}{c}\text { Desert } \\
\text { varnish }^{3}\end{array}$ & Rubification ${ }^{4}$ & $\begin{array}{c}\text { Depositional bar } \\
\text { relief }^{5}\end{array}$ & $\begin{array}{c}\text { Horizon } \\
\text { sequence }\end{array}$ & Structure & Clay films & $\begin{array}{l}\text { Maximum } \\
\text { reddening }\end{array}$ & $\begin{array}{c}\text { Maximum } \\
\text { carbonate } \\
\text { stage }^{8}\end{array}$ \\
\hline Qa7 & none & $\begin{array}{c}1 \pm 2 \\
12\end{array}$ & 4 & high, unaltered & $\mathrm{Cu}$ & sg & N.P. & 10YR & N.P. \\
\hline Qa6 & none & $\begin{array}{c}0 \pm 0 \\
0\end{array}$ & 0 & high, unaltered & A-Ck & sg & N.P. & 10YR & N.P. \\
\hline Qa5 & $\begin{array}{l}\text { weak to } \\
\text { moderate }\end{array}$ & $\begin{array}{c}1 \pm 1 \\
28\end{array}$ & 33 & $\begin{array}{l}\text { moderately } \\
\text { high, slightly } \\
\text { altered }\end{array}$ & $\begin{array}{c}\text { A-Bwk/Btjk- } \\
\text { Bk-Ck }\end{array}$ & $1 \mathrm{vf-f} s b \mathrm{k}$ & N.P. $-1 \mathrm{n}$ co & $10 Y R$ & I \\
\hline Qa4 & $\begin{array}{l}\text { moderate to } \\
\text { strong }\end{array}$ & $\begin{array}{c}62 \pm 27 \\
97\end{array}$ & 87 & low & $\begin{array}{l}\text { Av-Btkq- } \\
\text { Bkq-Ck }\end{array}$ & 2-3 f-m sbk & 3 n-mk pf & 7.5YR & I-II \\
\hline Qa3 & strong & $\begin{array}{c}42 \pm 28 \\
94\end{array}$ & 54 & low & $\begin{array}{c}\text { Av-BA- } \\
\text { Btkq- } \\
\text { Kq/Bkq-Ck }\end{array}$ & $3 \mathrm{~m} \mathrm{sbk}$ & 3 n-mk pf & 7.5YR & II+-III \\
\hline Qa2 & strong & $\begin{array}{l}80 \text { est. } \\
100 \text { est. }\end{array}$ & 100 est. & low & $\begin{array}{l}\text { Av-Btq- } \\
\text { Btkq-Kq- } \\
\text { Bkq-Ck }\end{array}$ & $3 \mathrm{~m} \mathrm{sbk}$ & $3 \mathrm{mk} \mathrm{pf}$ & 7.5-5YR & IV \\
\hline Qa1 & $\begin{array}{l}\text { locally } \\
\text { strong }\end{array}$ & $\begin{array}{c}20 \pm 21 \\
84\end{array}$ & 80 & none & $\begin{array}{l}\text { Av-BA- } \\
\text { Btkq-Kqm- } \\
\text { Bkq-Ck }\end{array}$ & $\mathrm{m}-3 \mathrm{~m} \mathrm{pl}$ & $2 \mathrm{npf}$ & 10-7.5YR & IV \\
\hline QT0 & & & aded & & & & Eroded & & \\
\hline
\end{tabular}

'See Wesling and others (1992, p. 17-19) for detailed definitions of surface parameters.

${ }^{2}$ Describes the relative degree of interlocking of surfaces clasts; based on qualitative estimate.

${ }^{3}$ First number is the average varnish cover (percent); second number refers to the percent of varnished clasts; from Wesling and others (1992, p. 20).

${ }^{4}$ Percent rubified clasts; from Wesling and others (1992).

${ }^{5}$ The relative height of depositional bars from the top of the bar to the trough of the adjacent swale.

${ }^{6}$ Refers to the sequence of soil horizons that is representative of each map unit.

${ }^{7}$ Hue determined with Munsell Soil Color Chart, Munsell Color Co., Inc. (1988).

${ }^{8}$ Terminology of Gile and others (1966) and Birkeland (1984). 
Table 4. Correlation of surficial units in Midway Valley with local and regional surficial stratigraphies.

[Numbers in parentheses refer to ages in thousands of years; >, greater than; <, less than; --, not applicable]

\begin{tabular}{|c|c|c|c|c|c|c|}
\hline $\begin{array}{l}\text { Midway Valley } \\
\text { (this study) }\end{array}$ & $\begin{array}{l}\text { Yucca Wash, Nev. } \\
\text { (Taylor, 1986; Swadley } \\
\text { and others, 1984) }\end{array}$ & $\begin{array}{c}\text { Crater Flat, Nev. } \\
\text { (Peterson and others, } \\
\text { 1995) }\end{array}$ & $\begin{array}{l}\text { Kyle Canyon Fan, Nev. } \\
\text { (Reheis and others, 1992) }\end{array}$ & $\begin{array}{l}\text { Fish Lake Valley, Nev.- } \\
\text { Calif. (Slate, 1991; } \\
\text { Harden, Slate, and } \\
\text { others, 1991) }\end{array}$ & $\begin{array}{l}\text { East-Central Mojave, } \\
\text { Calif. (Reheis and others, } \\
\text { 1989; Wells, McFadden, } \\
\text { and Harden, 1990) }\end{array}$ & $\begin{array}{l}\text { Lower Colorado River, } \\
\text { Calif.-Ariz. } \\
\text { (Bull, 1991) }\end{array}$ \\
\hline $\begin{array}{l}\text { Qa7 } \\
\text { (latest Holocene to } \\
\text { present) }\end{array}$ & $\begin{array}{l}\text { Q1b } \\
(0-15)\end{array}$ & $\begin{array}{l}\text { Modern } \\
\quad(0)\end{array}$ & $\begin{array}{l}\text { Q4 } \\
(0)\end{array}$ & Modern & $\begin{array}{l}\text { Modern } \\
\text { (0) }\end{array}$ & $\begin{array}{l}\text { Q4b } \\
(0)\end{array}$ \\
\hline \multirow[t]{3}{*}{$\begin{array}{c}\text { Qa6 } \\
\text { (late Holocene) }\end{array}$} & $\begin{array}{l}\text { Q1b } \\
(0-15)\end{array}$ & $\begin{array}{l}\text { Crater Flat } \\
(<0.4->1.5)\end{array}$ & -- & $\begin{array}{l}\text { Late Marble Creek } \\
\qquad(0.1-1)\end{array}$ & $\begin{array}{c}\text { Q3b3 } \\
(0.5-2.5)\end{array}$ & $\begin{array}{c}\text { Q4a } \\
(0.1-2)\end{array}$ \\
\hline & & & & $\begin{array}{c}\text { Middle Marble Creek } \\
\text { (1-6) }\end{array}$ & $\begin{array}{c}\text { Q3b2 } \\
(2.0-4.5)\end{array}$ & $\begin{array}{l}\text { Q3c } \\
(2-4)\end{array}$ \\
\hline & & & & $\begin{array}{c}\text { Early Marble Creek } \\
\qquad(2-5.8)\end{array}$ & & $\begin{array}{l}\text { Q3b } \\
(4-8)\end{array}$ \\
\hline $\begin{array}{l}\text { Qa5 } \\
\text { (late Pleistocene to } \\
\text { middle Holocene) }\end{array}$ & $\begin{array}{l}\text { Q1c } \\
(7-30)\end{array}$ & $\begin{array}{c}\text { Little Cones } \\
(>6.6-11.1)\end{array}$ & $\begin{array}{c}\text { Q3 } \\
(15,4-80)\end{array}$ & $\begin{array}{c}\text { Leidy Creek } \\
(6-11)\end{array}$ & $\begin{array}{l}\text { Q3b1 } \\
(6-11)\end{array}$ & $\begin{array}{c}\text { Q3a } \\
(8-12)\end{array}$ \\
\hline $\begin{array}{c}\text { Qa4 } \\
\text { (late Pleistocene) }\end{array}$ & $\begin{array}{c}\text { Q2b } \\
(145-290)\end{array}$ & $\begin{array}{l}\text { Late Black Cone } \\
\quad(>17.2-30.3)\end{array}$ & $\begin{array}{c}\text { Q3 } \\
(15,4-80)\end{array}$ & $\begin{array}{l}\text { Late Indian Creek } \\
\quad(>50-<700)\end{array}$ & $\begin{array}{c}\text { Q3a } \\
(13-50)\end{array}$ & $\begin{array}{c}\text { Q2c } \\
(12-70)\end{array}$ \\
\hline $\begin{array}{c}\text { Qa3 } \\
\text { (middle to late } \\
\text { Pleistocene) }\end{array}$ & $\begin{array}{c}\text { Q2c } \\
(270-440)\end{array}$ & $\begin{array}{l}\text { Early Black Cone } \\
\quad(>159-200)\end{array}$ & $\begin{array}{c}\text { Q2 } \\
(130,18-750)\end{array}$ & $\begin{array}{l}\text { Early Indian Creek } \\
\quad(>50-<700)\end{array}$ & $\begin{array}{c}\text { Q2b } \\
(110-130)\end{array}$ & $\begin{array}{c}\text { Q2b } \\
(70-200)\end{array}$ \\
\hline & & & & & $\begin{array}{c}\text { Q2a } \\
(140-190)\end{array}$ & \\
\hline $\begin{array}{c}\text { Qa2 } \\
\text { (middle Pleistocene) }\end{array}$ & $\begin{array}{c}\text { QTa } \\
(900-2000)\end{array}$ & $\begin{array}{c}\text { Yucca? } \\
(>343-375)\end{array}$ & -- & $\begin{array}{c}\text { Late Trail Canyon? } \\
\text { (<700 -- middle } \\
\text { Pleistocene })\end{array}$ & $\begin{array}{c}\text { Q1b } \\
(>400->650)\end{array}$ & $\begin{array}{c}\text { Q2a } \\
(400-730)\end{array}$ \\
\hline $\begin{array}{c}\text { Qa1 } \\
\text { (early to middle } \\
\text { Pleistocene) }\end{array}$ & $\begin{array}{c}\text { QTa } \\
(900-2000)\end{array}$ & $\begin{array}{c}\text { Solitario } \\
(>433-<730)\end{array}$ & $\begin{array}{c}\text { Q1 } \\
(800,750-800)\end{array}$ & $\begin{array}{c}\text { Early Trail Canyon } \\
\text { (<700 -- early } \\
\text { Pleistocene })\end{array}$ & $\begin{array}{c}\text { Q1b } \\
(>400->650)\end{array}$ & $\begin{array}{c}\text { Q2a } \\
(400-730)\end{array}$ \\
\hline $\begin{array}{c}\text { QT0 } \\
\text { (Pliocene? to early } \\
\text { Pleistocene?) }\end{array}$ & -- & -- & -- & & $\begin{array}{c}\text { Q1 } \\
(>650->800)\end{array}$ & $\begin{array}{c}\text { Q1 } \\
(>1200)\end{array}$ \\
\hline
\end{tabular}


Table 5. Late Cenozoic boundary dates.'

[ka, thousand years before present; Ma, million years before present]

\begin{tabular}{lll}
\hline \multicolumn{2}{c}{ Divisions of late Cenozoic } & \multicolumn{1}{c}{ Boundary dates } \\
\hline Holocene & late & historic-3 ka \\
& middle & $3-7 \mathrm{ka}$ \\
& early & $7-10 \mathrm{ka}^{2}$ \\
Pleistocene & late & $10-128 \mathrm{ka}^{3}$ \\
& middle & $128-736 \mathrm{ka}^{4}$ \\
& early & $736-1600{\mathrm{ka}(1.6-1.7 \mathrm{Ma})^{5}}^{\text {Pliocene }}$ \\
\end{tabular}

${ }^{1}$ Modified from E.M. Taylor (written commun., 1995); Quaternary time scale from Imbrie and others (1984).

${ }^{2}$ Arbitrary age suggested for Pleistocene-Holocene boundary (Hopkins, 1975).

${ }^{3}$ Astronomical age of marine oxygen-isotope substage 5e boundary.

${ }^{4}$ The Brunhes-Matuyama geomagnetic reversal.

${ }^{5}$ Provisional age of the proposed Pliocene-Pleistocene boundary at the end of the Olduvia polarity subchron (event) in the Vrica stratotype, southern Italy (Aguirre and Pasini, 1984).

regions, grain size is greater where larger material is available for transport and where streamflow is concentrated. In the distal reaches of the fans sediment is finer grained, although coarser grained facies are present locally. Gravel size ranges from pebble to boulder, and clasts generally are subangular to subrounded. In soil-pit and stream-cut exposures of units Qa5, Qa6, and Qa7, the cross-sectional bar-and-swale characteristics are so well preserved that the changes in facies between the bars and swales are readily observed. The deposits associated with depositional bars include nonindurated, cobbleboulder gravel and a finer grained sand and gravel deposit. The deposits associated with swales include a finer grained, siltrich, sandy gravel, and gravelly sand. The boulder gravel associated with the bars typically is about $0.5 \mathrm{~m}$ thick. Unweathered deposits are light gray (10YR $7 / 2 \mathrm{~d}$ ), poorly to moderately sorted, massive to well bedded, and clast supported to matrix supported. (Color notation refers to Munsell Soil Color Chart (Munsell Color Company, 1988); d = dry, $\mathrm{m}=$ moist.) Rodent burrows are ubiquitous on Qa5 and Qa6, most likely reflecting the ease of excavation. Qa5 and younger deposits are relatively unconsolidated and do not hold a well-formed free face when excavated.

Debris-flow deposits were observed locally in natural outcrops, soil pits, and trenches (for example, trench MWV-T5, pl. 4). These deposits are matrix supported and have pebbly to cobbly, silty, fine- to medium-sand texture. The gravel fraction makes up approximately 15-30 percent of the deposit. Debrisflow deposits are nonbedded and massive and have a relatively hard consistency.

With time, surface weathering, soil formation, and eolian additions result in incremental modifications to geomorphic surfaces. These modifications include reduction of original surface topographic relief (bar-and-swale relief), formation of Av horizons, desert pavement development, the accumulation of desert varnish on surface clasts, and weathering of surface clasts. In Midway Valley, these modifications have produced a distinctive surface morphology for a unit of a given age, and the surface morphology is used as a basis for mapping alluvial geomorphic surfaces. Relative to younger surfaces, older surfaces generally have a more subdued surface topography, stronger desert pavement development, darker and thicker desert varnish on surface clasts, and stronger soil development.

Given the similarities in sedimentologic properties of deposits among the various map units, distinctive surface properties and soil-profile characteristics as discussed above were used as criteria for delineating and correlating map units within the study area. These data, combined with available numerical-age information, serve as a basis for assigning ages to units through correlations with local and regional soilstratigraphic studies. The characteristics of eight identified alluvial geomorphic surfaces, their associated soil profiles, the available numerical age control for the Midway Valley area, and correlations with local and regional studies are described below for each major mapped unit.

\section{Pliocene(?) to Early Pleistocene(?) Alluvium (QTO)}

Within the mapped area, unit QT0 consists of a single terrace remnant on the upthrown block of the Paintbrush Canyon fault at the north end of Alice Ridge. The surface forms a pronounced topographic bench (altitude $1,168 \mathrm{~m}$ ) that is 25 $\mathrm{m}$ higher than Qa1 and $46 \mathrm{~m}$ above the active channel of Yucca Wash. Deposits associated with QT0 consist of lag gravel on a bedrock surface eroded into the Tiva Canyon Tuff. Clast lithologies that include the rhyolites of Fortymile Wash are sufficiently abundant and distinct to indicate that they are exotic to Alice Ridge. No outcrops of deposits associated with QT0 were observed elsewhere in Midway Valley. Because of its limited areal extent and the extensive post-depositional erosion of the surface, no detailed soils data were collected for the QT0 surface (table 3). The thickness of the unit is unknown but is probably only a few meters. Its age probably is Pliocene(?) to early Quaternary, based on stratigraphic position relative to Qa1, its highly dissected and eroded nature, and its rounded landform morphology.

\section{Early to Middle Pleistocene Alluvium (0a1)}

Unit Qa1 is preserved at the surface only on the Yucca Wash alluvial fan north of Sever Wash; the fan surface has been dissected by younger drainages and is preserved as somewhat rounded interfluves. Locally, the desert pavement associated with the Qa1 surface is well developed, but in most areas it has been extensively degraded (table 3 ). Characteristics such as freshly exposed rock surfaces on clasts, fragments of carbonate and silica, and surface or near-surface calcic horizons collectively impart a lighter tonal quality to the unit when viewed in the field or on aerial photographs. Although 
darkly varnished clasts are present in some areas, surface clasts typically are not darkly varnished. No original depositional bar-and-swale morphology is preserved on the surface, and larger clasts appear to be distributed randomly rather than being concentrated in areas that define depositional bars. Angular unvarnished rock fragments are common on the surface, where larger varnished clasts have spalled, exposing fresh rock surfaces. Many clasts are fractured and strongly weathered. The total thickness of Qa1 cannot be determined from available exposures. A buried soil was observed beneath Qa1 at a depth of $2.5 \mathrm{~m}$ in one soil pit, but no buried soils were encountered to depths of more than $3.3 \mathrm{~m}$ in other soil pits on Qa1 (see Appendix).

The strongly developed Qa1 soil is greater than 1.5-2.0 $\mathrm{m}$ thick and has a laminar petrocalcic horizon (Kqm) with stage-IV carbonate morphology at or near the surface (table 3; Appendix). The petrocalcic horizon may be overlain by as much as $30 \mathrm{~cm}$ of eolian fine sand and silt. Soil development on the eolian deposits is characterized by brownish to reddish (10-7.5YR) argillic horizons (Btk, Btkq) that have strong, medium subangular blocky structure and continuous, moderately thick clay films. The soil developed in the overlying eolian sand and silts appear to be much younger than the underlying petrocalcic horizon formed in alluvial sediments.

Age control for Qa1 indicates that the unit is probably early to middle Pleistocene (table 4). Swadley and others (1984) mapped QTa (= Qa1) in northern Midway Valley where Qa1 is present, and Hoover (1989) noted that the best developed soils and landforms that are representative of QTa occur in northern Midway Valley. These investigators assigned a Pliocene to early Pleistocene age to QTa, but Hoover (1989) noted that the unit is probably Pleistocene in age. In other parts of the Yucca Mountain area, deposits mapped as QTa overlie alluvial sediments of the ancestral Rock Valley Wash that contain a 2.1-Ma ash (Swadley and others, 1984). Swadley and others (1984) and Hoover (1989) noted that eolian and alluvial sediments younger than QTa contain Bishop tephra at various locations within the Yucca Mountain area. However, M.C. Reheis (oral commun., 1993) and Peterson and others (1995) reported Bishop tephra within alluvial deposits that were mapped as QTa by Swadley and others (1984) in northeastern Crater Flat. Peterson and others (1995) mapped this unit in Crater Flat as their Solitario geomorphic surface and assign a numerical age between about 730-430 ka based on the varnish cation-ratio ages and the reported presence of the Bishop tephra. The association of the Bishop tephra with Qa1 sediments may be corroborated by the work of Davis (1983) and Scott Lundstrom (oral commun., 1994), who found Bishop-like silicic ashes along Yucca Wash. As noted previously, Bishop ash was dated as approximately $760 \mathrm{ka}$ by Sarna-Wojcicki and others (1993).

An early to middle Pleistocene age for Qa1 is supported by regional soil-stratigraphic correlations. The somewhat rounded, eroded morphology of Qa1 surfaces and the strongly developed soil on Qa1 are similar to those on early to middle Pleistocene units in Nevada and California (table 4) (Taylor,
1986; Wells and others, 1990; Harden, Slate, and others, 1991; Harden, Taylor, Hill, and others, 1991; Slate, 1991; Reheis and others, 1992; McDonald and McFadden, 1994).

\section{Middle Pleistocene Alluvium (0a2)}

Unit Qa2 is recognized at the surface primarily in the region north of Sever Wash, where it is inset into Qa1. On color aerial photographs, Qa2 surfaces have a darker, more reddish hue than the other units. This darker color and reddish hue reflect more compact and continuous desert pavement, better developed desert varnish, and the presence of reddish Bt horizons near the surface. Qa2 has a well-developed desert pavement that contains darkly varnished clasts (table 3 ). Some clasts are split and fractured, and varnish also has developed on some fractured surfaces of clasts. The original bar-andswale morphology has been reduced to the height of the larger clasts above the surface. The upper part of the unit typically has a cap of eolian silt and fine sand ranging from $30 \mathrm{~cm}$ to 50 $\mathrm{cm}$ thick. The total thickness of Qa2 varies from $2.5 \mathrm{~m}$ to more than $3.5 \mathrm{~m}$ as observed in soil pits.

The strongly developed Qa2 soil has a 40- to 70-cmthick, reddish (7.5-5YR) argillic horizon (Btkq) and a zone of carbonate and silica accumulation having stage-II to -III+ carbonate morphology (table 3). The upper solum (Av and Btkq horizons) of the Qa2 soil is cumulic (continually adding new soil materials at the surface) and has formed in the eolian sediments that have accumulated on the surface (table 3; Appendix). The upper part of the Btkq horizon lacks much carbonate but contains a silica-cemented zone that is reddish brown to yellowish red (5YR 5/4-6 d) in color and is laminar in appearance. Therefore, the morphology of the upper part of the soil reflects silica accumulation, whereas the morphology of the lower part of the soil is affected by both carbonate and silica accumulation. This accumulation gives the Qa2 soil an appearance of overall stage-IV morphology.

A middle Pleistocene age for Qa2 is supported by (1) its stratigraphic position between the early to middle Pleistocene Qa1 and the middle to late Pleistocene Qa3, and (2) the degree of soil-profile development. The degree of soil-profile development on the Qa2 alluvial geomorphic surface appears to be similar to that on Q2c or QTa of Taylor (1986); Harden, Taylor, Hill, and others (1991); and Harden, Taylor, Reheis, and others (1991). On the basis of correlations with local and regional soil chronosequence studies, Qa2 is probably middle Pleistocene in age (table 4$)$.

\section{Middle to Late Pleistocene Alluvium (0a3)}

North of Sever Wash, unit Qa3 occurs as small, inset fluvial terrace remnants along drainages eroded into Qa1 and Qa2 on the Yucca Wash fan. The unit occurs south of Sever Wash as large remnant alluvial fan surfaces and as fluvial terraces. A well-developed desert pavement that contains darkly varnished clasts characterizes the Qa3 surface that has a dark brown or black tone on color aerial photographs (table 3). 
Larger clasts, some more than $30 \mathrm{~cm}$ in diameter, are distributed on the surface in diffuse, poorly defined bars. (Clast size as given in this report is maximum intermediate diameter unless otherwise stated.) The original depositional bar-andswale morphology has been reduced to the height of individual clasts above the surface. The thickness of Qa3 averages approximately $2-2.5 \mathrm{~m}$ and may exceed $3.3 \mathrm{~m}$ locally as observed in soil pits.

The strongly developed Qa3 soil has an approximately 75-cm-thick Bt and Btkq horizon overlying a 100- to 130-cmthick horizon of secondary carbonate and silica accumulation (table 3; Appendix). A clayey texture, clay films, reddish color (7.5YR), and strong blocky structure are characteristic of the argillic horizon that also has accumulations of secondary carbonate and silica. A Bkq or weakly developed Kq horizon having stage-II to -III carbonate morphology typically underlies the Btkq horizon.

The middle to late Pleistocene age for Qa3 is supported by stratigraphic relations, numerical dating, and correlations with local and regional soil-stratigraphic studies. Areas mapped as Qa3 by Wesling and others (1992) within Midway Valley were mapped as Q2 by Swadley and others (1984) and Q2c by Taylor (1986); Harden, Taylor, Hill, and others (1991); and Harden, Taylor, Reheis, and others (1991); who consider the unit to be 440-270 ka on the basis of uranium-trend dating of deposits exposed in fault trenches (Hoover and others, 1981; Szabo and others, 1981; Swadley and Hoover, 1983).

Menges and others (1994) correlate colluvial deposits in trench 14D with Qa3 on the basis of a similar degree of soilprofile development on these units. Uranium-series dating of pedogenic carbonate associated with these colluvial deposits in the trench yielded an age of $234 \pm 47 / 35 \mathrm{ka}$, and a thermoluminescence age of $132 \pm 23 \mathrm{ka}$ on a mixed eolian-colluvial unit that composes the middle part of the sequence correlated with Qa3 (Menges and others, 1994, 1997; J.B. Paces, written commun., 1995). Four uranium-series ages of about 140-100 $\mathrm{ka}$ also were obtained on pedogenic carbonate in the uppermost part of the Qa3 sequence in trench 14D.

Apparent similarities in soil-profile development may indicate that Qa3 correlates with the Early Black Cone surface in Crater Flat (Peterson and others, 1995). The degree of soil development on Qa3 also is similar to that on middle to late Pleistocene soils in other parts of the Western United States (Taylor, 1986; Wells, McFadden, and Harden, 1990; Harden, Slate, and others, 1991; Harden, Taylor, Reheis, and others, 1991; Slate, 1991; Reheis and others, 1992; McDonald and McFadden, 1994). The correlation of Qa3 with regional chronosequence studies that indicate stage-III carbonate morphology generally occurs in middle to late Pleistocene soils is shown in table 4.

\section{Late Pleistocene Alluvium (Oa4)}

Unit Qa4 consists of small, inset fluvial terrace remnants north of Sever Wash and of alluvial fan and fluvial terrace remnants to the south of the wash. The desert pavement of the
Qa4 surface ranges from loosely to tightly interlocking and is noticeably less well developed than pavements formed on the older fluvial surfaces. Although desert varnish is discernible on surface clasts of the Qa4 pavement, it occurs at a much lower percentage than on surface clasts of older units (table 3 ). Indistinct depositional bars are preserved as diffuse accumulations of larger clasts; bar-and-swale relief on Qa4 has been mostly reduced to clast height above the surface. The thickness of Qa4 averages about $1 \mathrm{~m}$ and does not exceed $2 \mathrm{~m}$ where observed in soil pits and trenches.

The strongly developed Qa4 soil is characterized by a red (7.5YR) argillic horizon and accumulations of carbonate and silica (table 3; Appendix). The upper part of the soil has silica accumulation, stage-I to -II carbonate morphology, and a strongly developed Btkq horizon with a sandy or silty clay loam texture. Continuous, thin to moderately thick clay films coat ped faces of the Btkq. An Av horizon overlies the Btkq horizon.

Qa4 is estimated to be late Pleistocene in age on the basis of its stratigraphic position, thermoluminescence ages from fault trenches, and the degree of soil-profile development. A thermoluminescence age of $27 \pm 5$ ka was obtained for an Avb horizon of Qc4 in trench MWV-T5 (table 2). The Avb represents post-depositional eolian accumulation on Qc4; therefore, the age represents a minimum estimate for the depositional age of Qc4. Eolian/colluvial sediments that have similar soil-profile development as Qa4 yielded thermoluminescence ages of $73 \pm 9 \mathrm{ka}$ and $38 \pm 6 \mathrm{ka}$ in trench MWV-T4 (table 2). J.B. Paces and others (written commun., 1995) reported a preliminary thermoluminescence age of $48 \pm 20 \mathrm{ka}$ for the upper part of a unit with a strongly developed Btkq horizon, which Menges and others (1994) correlated with Qa4.

Additionally, a late Pleistocene age for Qa4 appears to be reasonable based on comparisons of soil morphology data with those of regional chronosequences (table 4). These comparisons indicate that Qa4 soil has morphologic characteristics similar to soils formed on units that were deposited about 80 to $20 \mathrm{ka}$ (Taylor, 1986; Wells and others, 1987; Harden, Slate, and others, 1991; Harden, Taylor, Hill, and others, 1991; Slate, 1991; Reheis and others, 1992; Peterson and others, 1995).

\section{Latest Pleistocene to Holocene Alluvium (Qa5)}

Unit Qa5 covers large areas of alluvial fans south of Sever Wash; north of Sever Wash, Qa5 occurs as inset terraces along drainages incised into the Yucca Wash alluvial fan. The desert pavement is loosely packed and poorly formed, and surface clasts have minor accumulations of rock varnish (table 3). Qa5 surfaces display well-developed bar-and-swale morphology. The amount of bar-and-swale relief is related to landscape position and sediment sources; coarsest grained bars lie in the proximal fan regions north, south, and west of Exile Hill. Smaller, lower, partly buried bars lie in distal regions of Sever Wash, where the intervening swales are partly filled by finegrained eolian silts and sands. Surface clasts are relatively unweathered. In soil-pit and trench exposures, the average 
thickness of Qa5 is approximately $1 \mathrm{~m}$, and the maximum observed thickness is about $2.5 \mathrm{~m}$.

Weakly developed soils are formed on Qa5 (table 3; Appendix). Soil development is stronger in the swales where a silt-rich zone occurs in the upper $30-40 \mathrm{~cm}$ of the unit; soils are more weakly developed on bars. The Qa5 soil typically has a Bwk or incipient Btjk horizon with brownish (10YR) hues, weak subangular blocky structure, and colloidal stains on grains. Carbonate is disseminated in the matrix, and below about 30-cm-depth in the Bk horizon, the bottoms of clasts have powdery coats of carbonate (stage-I carbonate morphology). Where Qa5 is relatively thick, the carbonate content decreases below the $\mathrm{Bk}$ to form a transitional horizon (BC or $\mathrm{CB}$ ) or a $\mathrm{Ck}$; where Qa5 is relatively thin and underlain by a buried soil, the Bk persists to the base of the unit.

Qa5 is assigned a late Pleistocene to middle Holocene age, which is consistent with a maximum age of $27 \pm 5$ ka determined by TL dating of a buried Qc4/Qa4 soil (Av horizon, sample TL-01, table 2) that lies directly beneath Qc5 in trench MWV-T5 (pl. 4B, see note on trench log at station $240 \mathrm{~m}$ ). Samples from unit Qa5 in soil pits MWV-P10 and MWV-P14 yielded TL ages of $7 \pm 1 \mathrm{ka}$ and $4.0 \pm 0.7 \mathrm{ka}$, respectively (J.B. Paces and others, written commun., 1995). The presence of extensive burrowing and the translocation of fine material by soil-forming processes may account for these somewhat younger than expected TL ages. However, the weakly developed Qa5 soil appears to have similar profile characteristics as latest Pleistocene to Holocene units described in nearby and regional soil-stratigraphic studies (table 4). The color B horizon that is characteristic of most Qa5 soil profiles is a further indication that the unit may be as young as early to middle Holocene in age (Dohrenwend and others, 1991; McFadden, 1988).

\section{Middle to Late Holocene Alluvium (Qa6)}

Unit Qa6 occurs along the active washes as low floodplains less than $1 \mathrm{~m}$ above the active channels and as vegetated bars. No desert pavement has developed (table 3), and surface clasts are unvarnished and unweathered. Relief on the Qa6 surface is primarily the result of preservation of original barand-swale morphology. Locally, an eolian cap as much as 5-10 $\mathrm{cm}$ thick may bury all but the largest surface clasts. Natural outcrops and man-made exposures indicate that the total thickness of Qa6 does not exceed $2 \mathrm{~m}$.

Qa6 soils lack a well-developed eolian cap that is common to the older surfaces (Av horizon), and soil development is limited to minimal oxidation of the deposit (formation of Cox) and sparse accumulation of carbonate (table 3 ). Carbonate is more concentrated toward the upper $10 \mathrm{~cm}$ of the deposit, although the matrix typically contains widely disseminated carbonate. Clasts in the upper $30 \mathrm{~cm}$ have little visible carbonate, yet they effervesce when hydrochloric acid is applied. Carbonate varies from isolated patches on the undersides of clasts to thin, relatively continuous coatings. Evidence that many clasts within the deposit have been reworked from older deposits includes randomly oriented carbonate coatings on clasts and percussion marks where the coatings are chipped from the clasts.

Qa6 is assigned a middle Holocene to historic age because of its very weak to weak soil development and its inset nature with Qa5. There is no color or structural B-horizon development, and carbonate morphology varies from incipient to stage I. Historic is given as a minimum age because Qa6 receives sediments during overbank runoff events at the present time. Other middle to late Holocene alluvial units that have been recognized in the region are listed in table 4 .

\section{Late Holocene to Modern Alluvium (0a7)}

Unit Qa7 consists of the deposits along active channels and the adjacent floodplains. No desert pavement has formed on the Qa7 surface (table 3). No desert varnish occurs on clasts, except thick, dark desert varnish is present in small protected areas (small fractures and exposed voids) of some surface and subsurface clasts. This varnish is too well developed to be actively accreting in modern channels and apparently has been reworked from older surfaces. Clasts are unweathered, and the original depositional bar-and-swale relief is unaltered. The total exposed thickness of Qa7 does not exceed $2 \mathrm{~m}$.

No in situ pedogenic alteration of Qa7 deposits was observed (table 3; Appendix). The overall color of the unit is pale brown to brown (10YR 5-6/3 d). The matrix contains reworked, disseminated carbonate. Reworking of older surficial units is indicated by numerous clasts that have thick accumulations of carbonate. These clasts appear to be distributed randomly throughout the deposit. The coatings, which originally formed on the bottoms of the clasts, have no preferred orientation in the reworked deposits. Carbonate generally is not apparent on the undersides of clasts, but noticeable effervescence occurs when hydrochloric acid is applied. This unit includes modern sediments being deposited in channels (Qa7) and on hillslopes (Qc7).

\section{Colluvial Deposits}

Colluvial deposits are undifferentiated on the 1:6,000-scale map of Wesling and others (1992) because of their limited areal extent and the limited exposure of all but the youngest deposits. However, a sequence of colluvial deposits was exposed in trenches and soil pits at the prospective surface facilities site on the east side of Exile Hill (fig. 7). The colluvial stratigraphy of Midway Valley, as described below, primarily is based on the trench and soil pit exposures.

A unit designated as middle Pleistocene to Holocene undifferentiated colluvium occurs as colluvial and debris-flow deposits mantling hillslopes and, locally, includes areas mantled by eolian and reworked eolian deposits. The colluvial deposits consist of gravelly silty sands and silty fine to medium gravel with pebble to small cobble clasts. The color of the deposits is very pale brown (10YR 7/4 d) to reddish 
yellow (7.5YR 6/6 d) with white (10YR 8/1 d) for the older carbonate-cemented units. The colluvial deposits and debris flows are poorly sorted, nonbedded to crudely bedded, and predominantly matrix-supported (locally clast-supported), with as much as 90 percent gravel. The gravels are predominantly medium to very coarse, subangular to angular pebbles with lesser abundances of cobbles as much as $20 \mathrm{~cm}$ diameter and small boulders as much as $30 \mathrm{~cm}$ diameter. The thickness of individual colluvial units generally is less than $2-3 \mathrm{~m}$ based on trench and soil pit exposures.

The younger colluvial deposits, possibly equivalent to Qa5, have thin, weakly developed soils with an AB horizon over a weakly developed Bwk horizon. Colluvium of probable Qa4 age displays well-developed Btkq textural B horizons $40-50 \mathrm{~cm}$ thick. Units possibly equivalent to Qa3 and Qa2 have multiple superimposed soils consisting of Bkq and Btjkq horizons that have stage-II carbonate morphology. The oldest exposed colluvium deposits have strongly developed Kqm horizons.

At the surface, most of the hillslope areas mapped as undifferentiated colluvium along the margins of Midway Valley have surface characteristics of Qa5 and Qa6. Colluvium having surface characteristics similar to Qa4 surfaces commonly are near the toe of the hillslope.

\section{Eolian Deposits}

Two types of eolian sediment were observed in the Midway Valley area: (1) reworked eolian deposits within sand ramps along the southeastern margin of Midway Valley, and (2) thin accumulations of silt and fine sand in the A and B horizons of most surface soils and relict accumulations within some buried soils.

Sand ramps in southeastern Midway Valley are composed of a stacked sequence of eolian-colluvial units that have textures of pebbly silty fine to medium sand interbedded with some sandy, pebble to cobble gravel. Minor, alluvial sandy pebble gravel deposits are present locally within these deposits. Sand-ramp deposits vary from very pale brown to light gray (10YR 7/2-4 d), are poorly to moderately sorted, and are moderately bedded to massive. The unit is predominantly matrix supported although the alluvial gravel and parts of some colluviums are locally clast supported. Gravel clasts are angular to subangular and commonly less than $5 \mathrm{~cm}$ in diameter, although some clasts are as large as $50 \mathrm{~cm}$ diameter. The maximum thickness of the sand-ramp deposits exceeds 4 m.

A weakly to moderately interlocking desert pavement occurs over most of the surface. Soil development in nearsurface deposits consists of a well-developed reddish yellow (7.5YR 6/6 d) Btkq horizon with a sandy clay loam texture that appears to be similar to the soil formed on Qa4. Typically, one or more buried soils occur within the sand-ramp deposits in Midway Valley. The buried soil observed within trench MWV-T4 (pl. 5) has a Kq horizon with stage-IV carbonate morphology. Additionally, multiple buried soils have been observed within Busted Butte sand-ramp deposits south of Midway Valley (Whitney and others, 1985; Whitney and Muhs, 1991; Menges and others, 1994).

The presence of Bishop ash in lower sand-ramp deposits at Busted Butte (Whitney and others, 1985; Menges and others, 1994) and at other localities near Yucca Mountain (Hoover, 1989) indicate that these landforms began forming within the region sometime shortly before $760 \mathrm{ka}$. Multiple buried soils above the Bishop tephra indicate that the accumulation of sand ramps is episodic and punctuated by surface stabilization and soil formation. At Busted Butte, some of these buried soils have been dated as middle to late Pleistocene using uranium-series disequilibrium methods (Menges and others, 1994; C.M. Menges, written commun., 1995; Paces and others, 1994; J.B. Paces, written commun., 1995). Thermoluminescence dates from the upper $3 \mathrm{~m}$ of sand-ramp deposits in southern Midway Valley, $73 \pm 9 \mathrm{ka}$ and $38 \pm 6 \mathrm{ka}$ (table 2), and Busted Butte, $36 \pm 10 \mathrm{ka}$ (Paces and others, 1994), indicate that the two most recent major depositional episodes on sand ramps occurred about 40-35 ka and about 80-60 ka. A thermoluminescence age of $6 \pm 1 \mathrm{ka}$ on the surface A horizon of a sand ramp in southern Midway Valley indicates that small-scale eolian additions were deposited in the Holocene (table 2).

A few centimeters to several tens of centimeters of eolian silt and fine sand have accumulated on most alluvial geomorphic surfaces and have been incorporated into soil profiles formed on those surfaces. These eolian accumulations are not mapped separately because of their broad areal distribution and relatively thin nature. Models of desert pavement and soil formation recognize the importance of eolian accumulations as a source for the fine earth fraction, carbonate, and other soluble salts that occur in otherwise clean sandy gravel deposits in arid regions (McFadden, 1982; Birkeland, 1984; McFadden and others, 1987; McFadden and Weldon, 1987; Harrison and others, 1990, 1994; McDonald and others, 1992; McDonald and McFadden, 1994; Wells and others, 1994).

Data from soil pits (Appendix) show that the relative thickness of eolian accumulations generally is greater on older units. Eolian additions to Qa6 and Qa7 are minimal at best, whereas eolian sediments plug the upper part of Qa5 deposits and partially fill paleo-swales to form a muted bar-and-swale topography. The surfaces of units Qa2, Qa3, and Qa4 are plugged with eolian sediments that form a continuous surface sheet and result in a nearly flat topography. The original eolian mantle on Qa1 has been stripped and replaced by a younger eolian mantle.

\section{Sequence of Deposits at the Prospective Surface Facilities Site}

The prospective surface facilities site (fig. 2) lies at the intersection of three landforms within Midway Valley: the Drill Hole Wash alluvial fan to the south, the lower Sever 
Wash alluvial fan to the north and east, and small colluviumdominated debris fans derived from Exile Hill to the west (Wesling and others, 1992). The prospective surface facilities site, located in the western part of the RCS, covers an area that includes parts of the lower Sever Wash and Exile Hill debris fans. The colluvium-dominated debris fans occur along the toe of Exile Hill and coalesce to form a small fan apron along the base of the slope. Fluvial deposits of the lower Sever Wash alluvial fan occur as dissected fan remnants.

The locations of trenches and soil pits at the prospective surface facilities site are shown in plate 2 . The combined length of these excavations is more than $700 \mathrm{~m}$, including the 340-m-long, east-west-oriented trench MWV-T5 (figs. 3 and 4; pl. 4). The excavations generally are 3-5 $\mathrm{m}$ deep and expose colluvium-dominated deposits of debris fans derived locally from Exile Hill, axial fluvial deposits of the lower Sever Wash alluvial fan, and Tertiary volcanic bedrock. Eolian and debrisflow deposits compose a small proportion of the exposed sediments.

Colluvium-dominated deposits occur mainly in the western part of the site and interfinger with fluvial deposits to the east (figs. 6 and 7). The colluvium-dominated deposits are massively bedded, poorly sorted accumulations of gravelly sand. Clasts generally compose less than $40-50$ percent of a depositional unit, are subangular to angular, and appear to be locally derived from the upper three units of Tiva Canyon Tuff exposed on Exile Hill. In contrast, fluvial deposits are poorly to moderately sorted and generally have a sandy gravel texture. Fluvial clasts, which generally compose more than 60 percent of a depositional unit, are subrounded to rounded, and many of the lithologies are exotic to Exile Hill. Sedimentary features indicative of fluvial transport include clast imbrication, graded bedding, and cut-and-fill channels.

On the basis of soil-stratigraphic relations and sedimentologic characteristics, the deposits at the prospective surface facilities site were subdivided into 12 colluvium-dominated units and seven alluvial units (fig. 7). As shown in figure 8 , pedologic and sedimentologic characteristics of individual units were sufficiently distinct to correlate units exposed in the various soil pits and trenches and to assign the units into principal age classes that correspond roughly to the principal age classes recognized in the alluvial stratigraphy of Midway Valley. From oldest to youngest, the units in the prospective surface facilities site that were encountered in trenches and soil pits are designated QTcu, Qc1, Qc2 and Qa2, Qc3 and Qa3, Qc4 and Qa4, Qc5 and Qa5, and Qc6-7 and Qa6-7. Soil-profile descriptions are given in the Appendix.

The oldest colluvium (QTcu), was exposed in trenches MWV-T5 and MWV-T7 (pls. 4 and 6), as well as in trench MWV-T6. At the west end of trench MWV-T5, this colluvium was subdivided into three units that are unconformable with both the underlying Tertiary bedrock and the overlying colluviums. QTcu consists of 20-60 percent subangular to angular clasts in a carbonate and silica matrix. The original sedimentologic characteristics of these deposits have been modified by impregnation with pedogenic carbonate and silica, and their initial texture was probably sandy pebble- and cobble-bearing gravel. A strongly developed soil having stage-IV carbonate morphology is characteristic of QTcu, whereas soils developed on younger colluvial units have much weaker calcic-silicic horizon development.

Unit Qc1 was observed only in trench MWV-T7 (pl. 6), where it unconformably overlies QTcu and underlies subunits Qc2 and Qc3. The correlation of Qc1 with Qa1 of the Midway Valley alluvial stratigraphy is based on its stratigraphic position in the trench exposure. This correlation is uncertain because of the relatively deep burial of Qc1 and the resulting weaker soil development in the trench unit relative to its surface counterpart.

Unit Qc1 has a sandy gravel to gravelly sand texture with 50-60 percent subrounded to subangular gravel; mean gravel size is large cobble. Clast lithologies are consistent with local derivation of the unit from Exile Hill. The overall reddish (7.5YR) hue of the unit results from soil development almost entirely through the unit; however, small pockets of brownish (10YR) parent material locally are present near the base of

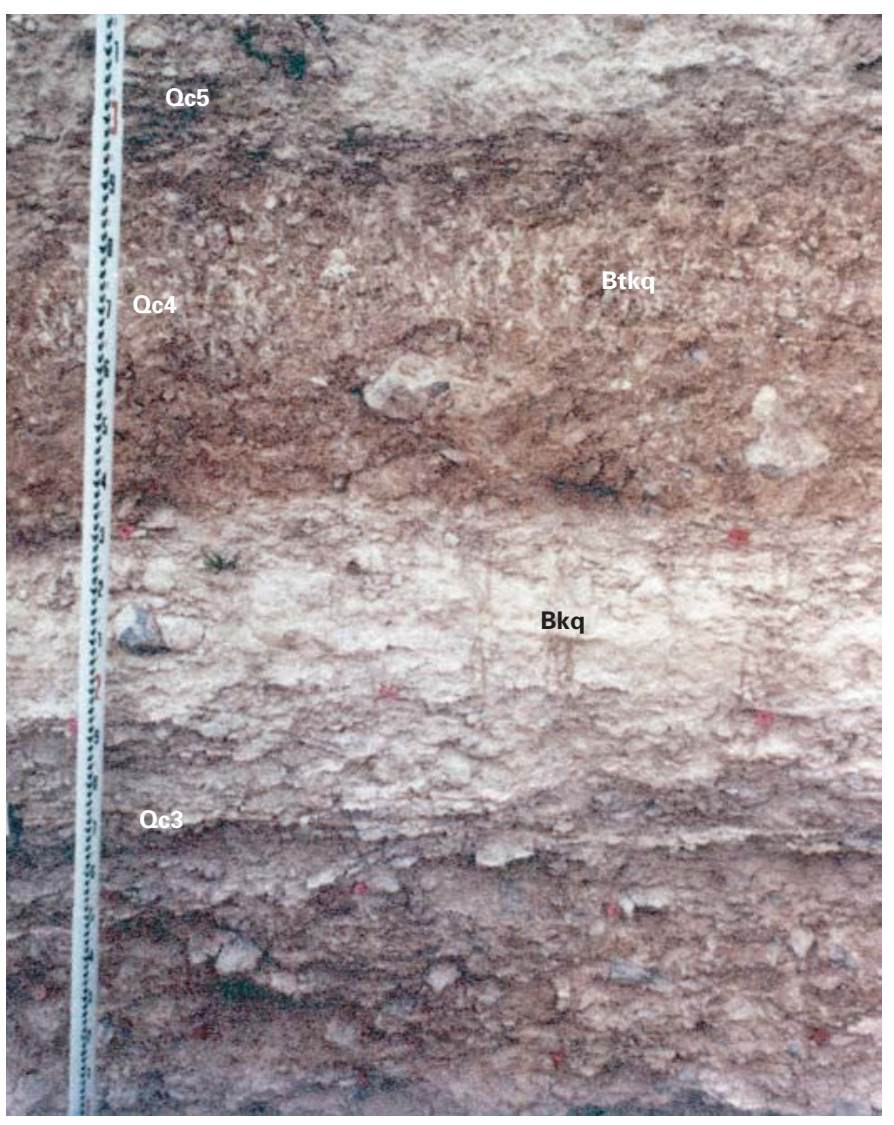

Figure 8. Photograph showing the strongly developed calcic soil (Bkq) formed on Qc3 colluvium and the strongly developed Btkq horizon formed on the overlying Qc4 colluvium. View is of south wall of trench MWV-T5 between stations $268 \mathrm{~m}$ and $269.5 \mathrm{~m}$ (pl. 4B). (Rod is scaled in meters, large numbers, and centimeters, small numbers). 
the unit. The strongly developed soil consists of a reddish yellow (7.5YR 7/6 d) Btkq horizon that is $35-40 \mathrm{~cm}$ thick. The lower contact with QTcu is erosional as indicated by its abrupt nature. The upper contact appears to be depositional and is marked by a prominent stone line.

Unit Qc2 unconformably overlies QTcu in trenches MWV-T5 and MWV-T7 (pls. 4 and 6), and also in trench MWV-T6. The unit consists of a pebbly, silty sand with 20-40 percent subangular gravel. Small cobbles as large as $10 \mathrm{~cm}$ diameter are present. Clast lithologies are consistent with local derivation of the unit from bedrock outcrops on Exile Hill. Unit Qa2 interfingers with Qc2 (near station $165 \mathrm{~m}$ on plate $4 \mathrm{~A}$ ), but this relation is not well exposed because of the limited depth of the trench.

At least three subunits of Qa2, designated Qa2a to Qa2c, are mapped within the eastern end of trench MWV-T5 (pl. 4). These subunits each have a sandy gravel texture with 40-70 percent subrounded pebbles and some small boulders as much as $28 \mathrm{~cm}$ in diameter. Some gravelly sand facies also are present. The units contain cut-and-fill channels and clast imbrication indicative of fluvial transport. Clast lithologies are dominated by tuffs of the Paintbrush Group, but rhyolite lithologies derived from north of Yucca Wash also are present. The subunits can be distinguished from each other by the (1) slightly lower clast content and more poorly sorted nature of Qa2c; (2) larger clast size of Qa2a; (3) abrupt, erosional upper and lower contacts of Qa2b with Qa2c and Qa2a, respectively; and (4) buried soils on units Qa2a and Qa2b. A strongly developed soil on Qa2c consists of a Btk-Btkqm-Bkqm-Kqm-Bk horizon sequence (see Appendix, description of soil profile for trench MWV-T5, 3-5 m). Stage-III to -IV carbonate morphology is characteristic of the Kqm horizon. The buried soil developed in Qa2a typically has a Btkq-Bkq-Bk horizon sequence with weak Bt development and stage-II carbonate morphology.

Unit Qc3 is composed of five subunits, Qc3a to Qc3e from oldest to youngest, that are conformable with each other and with underlying unit Qc2 (pls. 4 and 6). The Qc3 subunits interfinger with Qa3 alluvial sediments at about station $160 \mathrm{~m}$ in trench MWV-T5 (pl. 4). The Qc3 subunits have a pebbly to cobbly, silty sand texture and can be subdivided on the basis of soils formed in them and differences in characteristics such as color, average gravel size, and percentage of gravel (for soil descriptions, see Appendix, trench MWV-T5). The oldest subunit, Qc3a, is distinguished from younger subunits by its relatively low clast content and smaller average grain size. This subunit is mapped between stations $287 \mathrm{~m}$ and $303 \mathrm{~m}$ in trench MWV-T5 (pl. 4). No soil is preserved on Qc3a in that trench, but a strongly developed soil having a Btkq-Bkq-Ck horizon sequence is formed on Qc3a in trench MWV-T6.

Qc3b overlies Qc3a (where present) and Qc2 (between stations $190 \mathrm{~m}$ and $307 \mathrm{~m}$ in trench MWV-T5, pl. 4). The Qc3b deposit is predominately matrix supported and has a silty sand texture with approximately 30 percent subangular to angular pebbles and cobbles. The unit is $1-1.5 \mathrm{~m}$ thick and has sharp, erosional upper and lower contacts. The weakly to moderately developed soil formed on Qc3b has brownish to reddish hues
(10-7.5YR), weak argillic development, and stage-II carbonate morphology.

Colluvium Qc3c conformably overlies unit Qc3b

(between stations $272 \mathrm{~m}$ and $288.5 \mathrm{~m}$ in trench MWV-T5). The unit has a gravelly, silty sand texture with approximately 30 percent subangular to angular pebbles and cobbles as much as $13 \mathrm{~cm}$ in diameter. The upper and lower contacts are readily identified and are interpreted to be erosional in nature. The soil developed in this unit has a Btjkq horizon.

The slightly finer grained colluvium Qc3d conformably overlies units $\mathrm{Qc} 3 \mathrm{c}$ where present and $\mathrm{Qc} 3 \mathrm{~b}$ where $\mathrm{Qc} 3 \mathrm{c}$ is absent (trench MWV-T5, pl. 4). The unit is preserved between stations $233 \mathrm{~m}$ and $261 \mathrm{~m}$ and between stations $263 \mathrm{~m}$ and 315 $\mathrm{m}$. The unit has a silty sand texture with approximately $10-40$ percent subangular to angular pebbles and cobbles as much as $15 \mathrm{~cm}$ in diameter. The upper and lower contacts of the unit are interpreted to be erosional. The moderately developed soil on Qc3d has a Btjkq/Bkq horizon sequence, stage-II+ carbonate morphology, and a loamy sand texture (see Appendix, soil description for trench MWV-T5, $272 \mathrm{~m}$ ).

The Qc3e colluvium conformably overlies Qc3d where present and Qc3b where Qc3d is absent (trench MWV-T5, pl. 4). The unit is predominately matrix-supported and has a gravelly, silty sand texture with 7-25 percent subangular to angular gravel. Gravel size varies from coarse pebbles to small cobbles as much as $17 \mathrm{~cm}$ in diameter. The strongly developed Qc3e soil has a Btkq/Bkq-Kq horizon sequence (fig. 8). The maximum carbonate stage attained in the Bkq-Kq horizon is III to weak IV.

The five Qc3 subunits interfinger with Qa3 alluvial sediments between stations $158 \mathrm{~m}$ and $163 \mathrm{~m}$. No buried soils were observed within the alluvial deposits, indicating that individual depositional packages within Qa3 either did not have stabilized surfaces for sufficiently long periods of time to allow soil formation or that, less likely, soils had formed and subsequently were eroded.

Three facies compose unit Qa3: (1) a fluvial sandy gravel facies, (2) a fluvial gravelly sand facies, and (3) a debris-flow facies. The fluvial sandy gravel facies is the most abundant and has a clast-supported, sandy gravel texture with 60-70 percent subangular to subrounded pebbles and cobbles as much as 20 $\mathrm{cm}$ in diameter. This facies includes channel cut-and-fill morphology, imbricated gravel, and crossbedding. Clast lithologies are variable and most clasts were derived from the Paintbrush Group. Some lithologies within Qa3 are exotic to Exile Hill. The strongly developed soil on Qa3 has stage-II+ to -III+ carbonate morphology and a $\mathrm{Bkq} / \mathrm{Kq}-\mathrm{Bkq}$ horizon sequence. A minimum age of $41 \pm 8 \mathrm{ka}$ for Qa3 was obtained from the uppermost part of the platy K horizon in trench MWV-T5 (J.B. Paces and others, written commun., 1995). This young age is inconsistent with the degree of soil-profile development. The material that was dated would represent the last carbonate that was added to the $\mathrm{K}$ horizon, indicating an older age for the soil and for the deposit in which it is formed.

Unlike the older colluvial and alluvial facies, Qc4 and Qa4 are not laterally continuous and do not interfinger (trench 
MWV-T5, pl. 4). However, based on their stratigraphic position and distinctive soil-profile development, these two units appear to be correlative.

Unit Qc4 occurs as a hillslope colluvial wedge that thickens downslope but thins at the distal end. Erosion of the unit is highly variable. For example, unit Qc4 in trench MWV-T5 appears to be completely preserved between stations $264 \mathrm{~m}$ and $271 \mathrm{~m}$ and completely eroded between stations $165 \mathrm{~m}$ and $182 \mathrm{~m}$. The unit has a pebbly, silty sand texture and 15-20 percent subangular to angular, very coarse pebbles with some large cobbles as much as $20 \mathrm{~cm}$ in diameter. A strongly developed soil having a Avkq-Btkq-BCkq horizon sequence is formed on the unit. This soil has a reddish color (7.5YR), strong prismatic structure that breaks to angular blocky structure, many moderately thick clay films on ped faces, and stage-I carbonate morphology (fig. 8). A TL age of $27 \pm 5 \mathrm{ka}$ for unit Qc4 was obtained for the Av horizon of the unit where it is buried by Qc5 in trench MWV-T5 (table 2). Because this date represents the approximate age of eolian accumulation on Qc4 after deposition of that unit, it is a minimum age for deposition of Qc4.

Alluvial unit Qa4 is inset into Qa3 and appears to have backfilled to roughly the same level as Qa3, as indicated by the low surface relief between the two units. Qa4 buries Qa3 between stations $16 \mathrm{~m}$ and $154 \mathrm{~m}$ in trench MWV-T5. Following stabilization of the surface, the initially small surface relief, if any, between Qa4 and Qa3 had been eliminated through deposition of eolian silt and fine sand (pl. 4A, stations 15 to $20 \mathrm{~m}$ and 60 to $70 \mathrm{~m}$ ). Qa4 is mostly clast supported and has a sandy gravel texture. Qa4 contains very coarse pebbles and small cobbles with some large cobbles as much as $17 \mathrm{~cm}$ in diameter. Clasts are subangular to subrounded and locally imbricated. The soil developed on Qa4 is moderately to strongly developed (7.5YR), and has a sandy clay loam texture, moderate medium to coarse subangular blocky structure, thin to moderately thick clay films on ped faces and lining pores, and stage-I carbonate morphology (Appendix).

Units Qc5 and Qa5 are not laterally continuous and do not have an interfingering relation (fig. 7). Qc5 and Qa5 are correlated on the basis of stratigraphic position and soil-profile development. Unit Qc5 is the uppermost unit in the western $180 \mathrm{~m}$ of trench MWV-T5. Qa5 is preserved as small, lenticular (approximately 7-12 $\mathrm{m}$ wide and about $0.75 \mathrm{~m}$ maximum thickness) channel fills along small drainages in the eastern part of the trench, although Qc4 locally contains small inset lenses of Qa5 and alluvium is a small component of Qc5.

Qc5 is composed of colluvium that contains some small fluvial channels. The unit has a characteristic longitudinal cross-sectional morphology resembling that of a debris fan. The deposit is a matrix-supported, gravelly sand (25-30 percent gravel) with local lenses of clast-supported sandy gravel (90 percent). Clasts are subangular to angular and are predominately very coarse pebbles and small cobbles with minor small boulders as much as $30 \mathrm{~cm}$ in diameter. The presence of faint stone lines and the absence of buried soils indicates that the deposit accumulated episodically over a relatively short time period. The weakly developed soil on Qc5 has an Av$\mathrm{Bwk}(\mathrm{Btjk})-\mathrm{Bk}$ horizon sequence, brownish (10YR) hues, weak structure, and stage-I carbonate morphology.

Qa5 is restricted to relatively small channels that are inset into Qa3 and Qa4 (pl. 4). The channel deposits have a clast-supported sandy gravel texture, which contains 60-70 percent subangular to subrounded very coarse pebbles and small cobbles and some large cobbles as much as $17 \mathrm{~cm}$ in diameter. The weakly developed soil on Qa5 has an A-Bwk-Bk horizon sequence, brownish (10YR) hues, and stage-I carbonate morphology.

Younger colluvial deposits (Qc6, Qc7) were not directly encountered in the trenches, but surficial mapping located numerous small debris-flow lobes in the area along the eastern base of Exile Hill (fig. 7). Each lobe generally covers an area of less than $10 \mathrm{~m}^{2}$ and is composed of cobbles that are aligned along the margins of the flows. Many of the most recently deposited lobes have an open framework with only small amounts of fines between gravel clasts. Older lobes have larger proportions of fines, presumably of eolian or sheetwash origin, which plug the deposits. Many depositional lobes typically occur near the mouths of first-order drainages that rise on Exile Hill and are not integrated with the larger fluvial systems within the valley. Levees less than $30-40 \mathrm{~cm}$ high typically are present for short distances upstream of the lobes and in many cases are formed on unchannelized Qc5 sediments. Debrisflow lobes fill channels in places, and subsequent flow has either breached or been diverted around the lobe.

Alluvium associated with modern washes was encountered in the eastern part of MWV-T5 (pl. 4). Units Qa6 and Qa7 are composed of sandy gravel. These deposits are extremely limited in extent and are restricted to small drainages near stations $8 \mathrm{~m}, 80 \mathrm{~m}$, and $115 \mathrm{~m}$. Little or no soil development was observed on these units.

\section{Faulting in the Midway Valley Area}

Geologic mapping by Scott and Bonk (1984) and Day and others (1998), and for the present investigation, has identified two predominant fault trends in the vicinity of the RCS: (1) north- to northeast-trending normal faults represented by the Bow Ridge, Paintbrush Canyon, Midway Valley, and Exile Hill faults; and (2) northwest-trending right-lateral strike-slip to oblique-slip faults represented by the Drill Hole Wash, Pagany Wash, Sever Wash, East Portal, and West Portal faults (figs. 1 and 2; pl. 1). In addition to these faults, which locally are exposed at the surface, the available geophysical and subsurface data indicate the presence of other faults in the Tertiary bedrock beneath the unconsolidated valley-fill deposits. The geologic sections presented in figures 9A and 9B show two interpretations of geologic structure across the southern part of Midway Valley. Although the principal features-Bow Ridge, Midway Valley, and Paintbrush Canyon faults-are similarly drawn, the pattern of subsidiary faults 
differs according to individual concepts regarding the number and spacing of stratigraphic offsets required to explain the inferred structural relations. The mapping by Day and others (1998) also had considerably more geophysical and borehole data on which to base interpretations. A generalized geologic section across Exile Hill and the RCS is shown in figure 9C.

\section{North- to Northeast-Trending Faults}

The Bow Ridge, Paintbrush Canyon, and Midway Valley faults, the main north- to northeast-trending normal faults that have been identified in Midway Valley (figs. 1 and 2), are interpreted to have primarily down-to-the-west dip-slip displacement (Scott and Bonk, 1984; Day and others, 1998).
The Bow Ridge and Paintbrush Canyon faults are exposed locally in bedrock outcrops at the south and north ends of Midway Valley and in trenches along the valley margins. The Midway Valley fault is concealed beneath the surficial deposits within Midway Valley but also extends into bedrock areas to the south and north of the valley according to Day and others (1998). Geophysical data are interpreted to provide confirming evidence that the Midway Valley fault extends north-south beneath the valley alluvium (Ponce, 1993; Ponce and Langenheim, 1994). A fourth, much smaller fault that has down-to-the-east normal displacement occurs along the east margin of Exile Hill. This fault, informally named the Exile Hill fault, was first identified as a geophysical anomaly by the U.S. Geological Survey (1984, fig. 3) and was exposed in excavations in the western part of the prospective surface facility site (for example, "crushed" zone \#3, pl. 6).

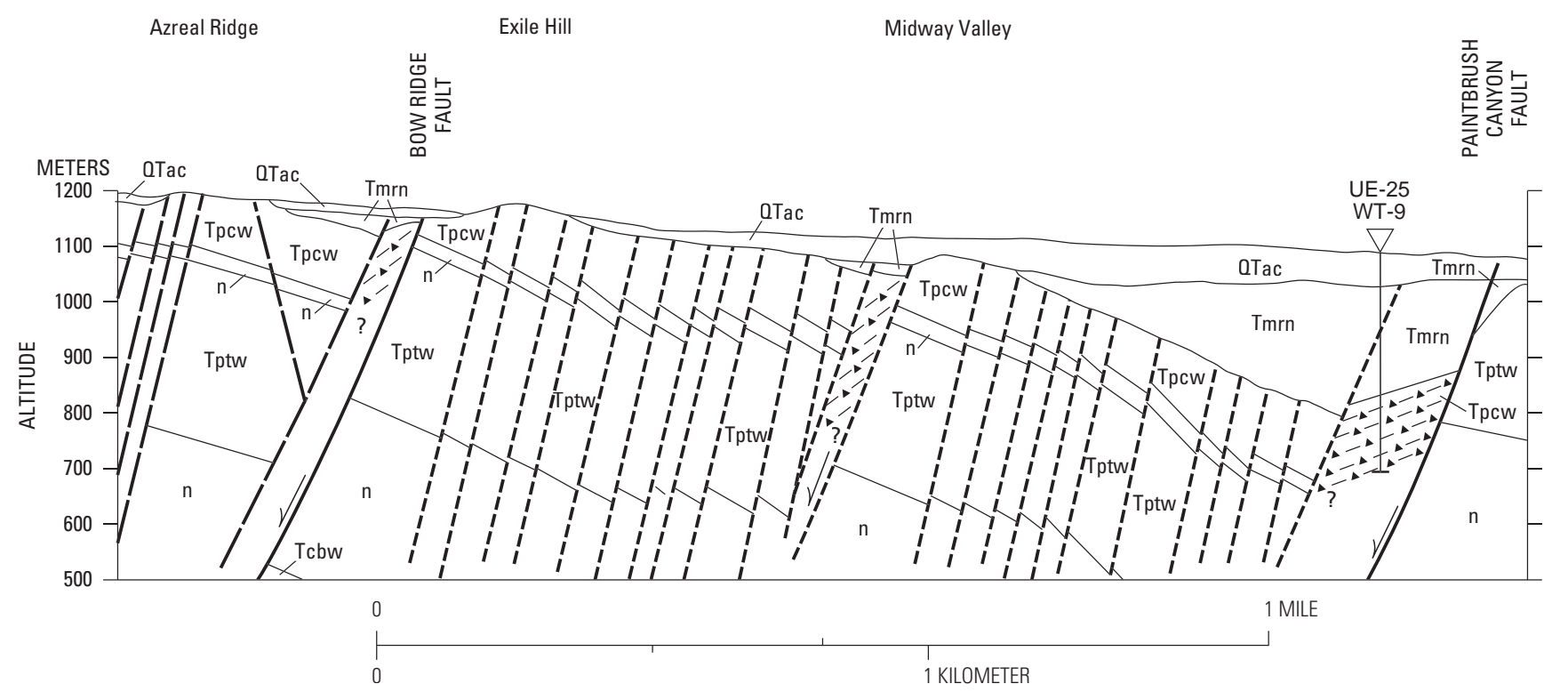

EXPLANATION

\begin{tabular}{|c|c|}
\hline QTac & Alluvium and colluvium \\
\hline Tmrn & Rainier Mesa Tuff, nonwelded \\
\hline$n$ & Nonwelded tuff \\
\hline Tpcw & Tiva Canyon Tuff, welded \\
\hline $\mathrm{n}$ & Nonwelded tuff \\
\hline Tptw & Topopah Spring Tuff, welded \\
\hline $\mathrm{n}$ & Nonwelded tuff \\
\hline Tcbw & Bullfrog Tuff, welded \\
\hline
\end{tabular}

Figure 9A. Structure section across Midway Valley by Scott and Bonk (1984). Fault in center of section is interpreted to be Midway Valley fault. Line of section shown on figure 1. Datum is sea level. 


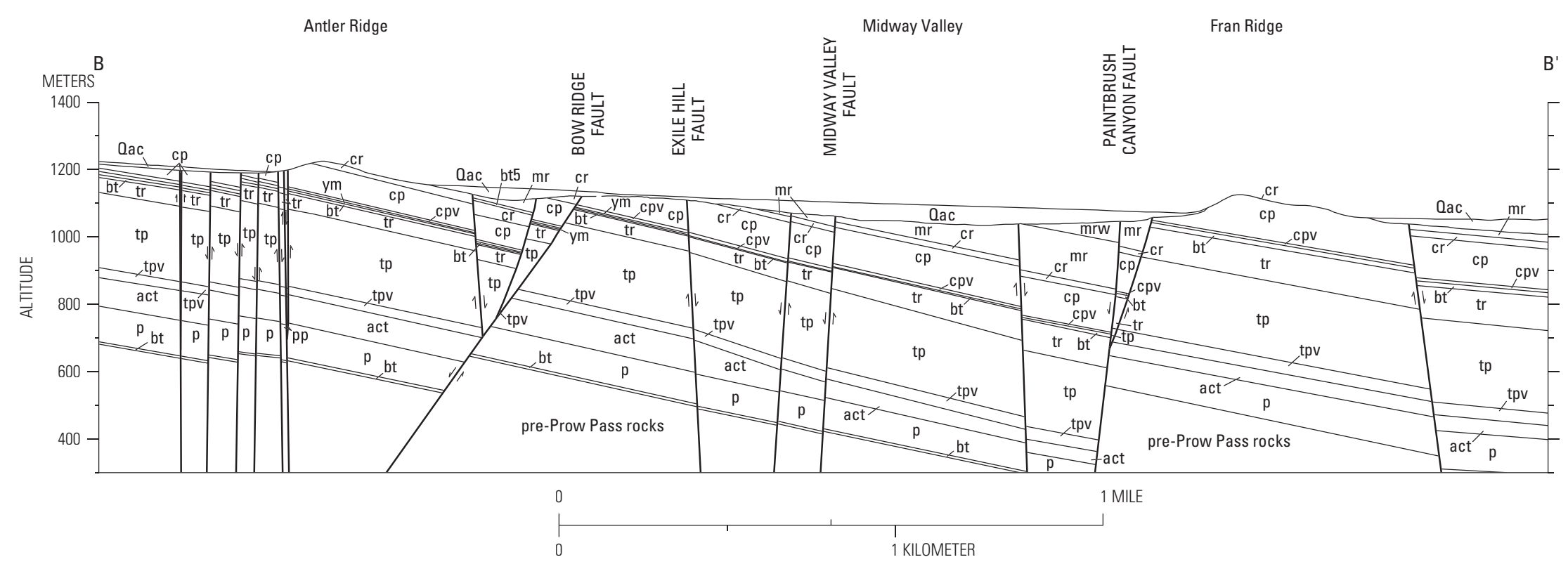

EXPLANATION

\begin{tabular}{|c|l}
\cline { 1 - 1 } Oac & \multirow{2}{*}{$\begin{array}{l}\text { Alluvium and colluvium } \\
\text { Rainier Mesa Tuff, welded }\end{array}$} \\
\cline { 1 - 1 } $\mathrm{mrw}$ & $\begin{array}{l}\text { Rainier Mesa Tuff, nonwelded } \\
\text { Tiva Canyon Tuff, crystal-rich member }\end{array}$ \\
\cline { 1 - 1 } $\mathrm{mr}$ & $\begin{array}{l}\text { Tiva Canyon Tuff, crystal-poor member } \\
\text { Crystal-poor vitric zone }\end{array}$ \\
\cline { 1 - 1 } $\mathrm{cr}$ & Yucca Mountain Tuff \\
\cline { 1 - 1 } $\mathrm{cpv}$ &
\end{tabular}

\begin{tabular}{|c|c|}
\hline bt & Bedded tuff \\
\hline $\operatorname{tr}$ & Topopah Spring Tuff, crystal-rich member \\
\hline tp & Topopah Spring Tuff, crystal-poor member \\
\hline tpv & Crystal-poor vitric zone \\
\hline act & Calico Hills Formation \\
\hline $\mathrm{p}$ & Prow Pass Tuff \\
\hline & Contact \\
\hline
\end{tabular}

$\simeq \quad$ Fault, arrow shows relative movement

Figure 9B. Structure section across Midway Valley by Day and others (1998). Line of section shown on figure 1. Datum is sea level. 


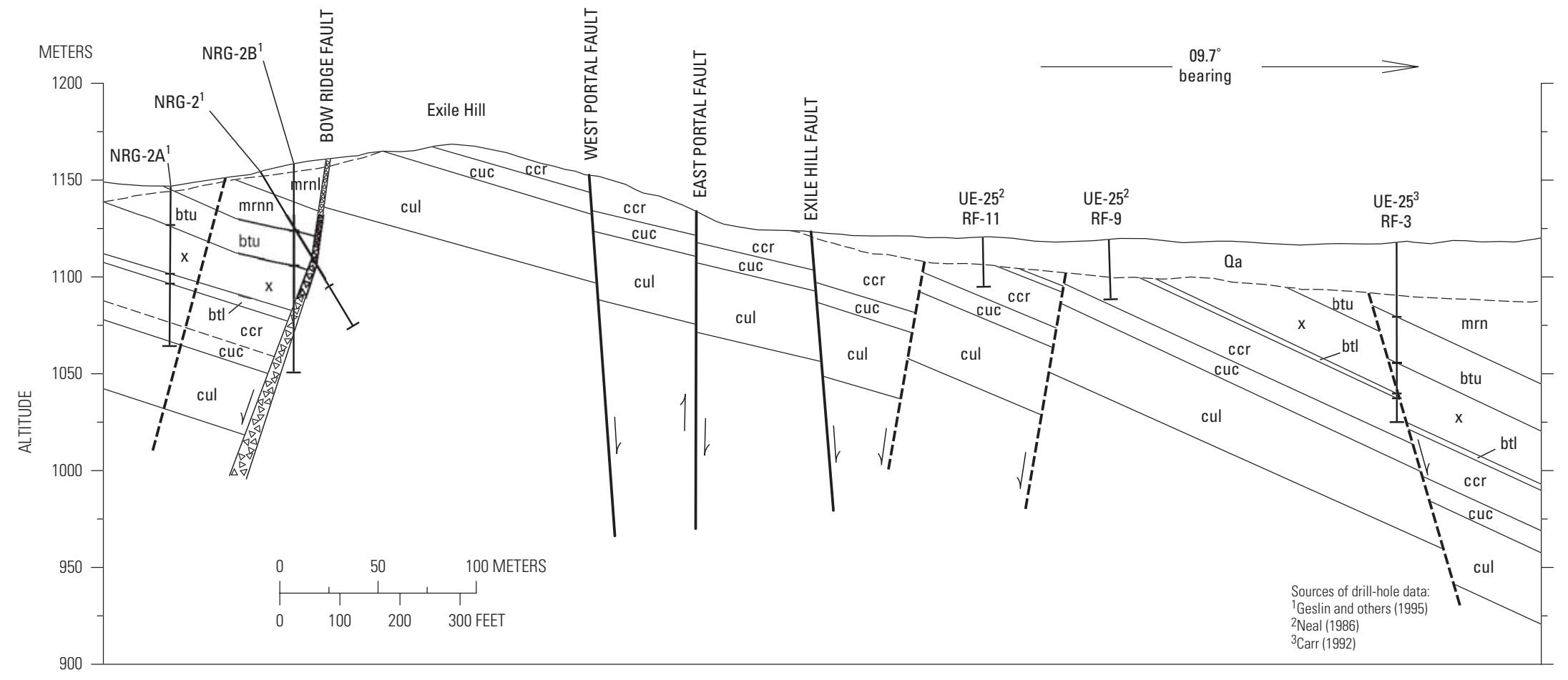

\begin{tabular}{|c|c|}
\hline 0a & Undifferentiated alluvium \\
\hline $\mathrm{mrn}$ & Rainier Mesa Tuff \\
\hline btu & Bedded tuff \\
\hline $\mathrm{x}$ & Tuff "x" \\
\hline btl & Bedded tuff \\
\hline
\end{tabular}

\section{EXPLANATION}

\begin{tabular}{|c|c|}
\hline $\mathrm{ccr}$ & Caprock* \\
\hline cuc & Upper cliff* \\
\hline cul & Upper lithophysal* \\
\hline 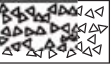 & Fault breccia \\
\hline
\end{tabular}

Lithologic unit contact

dashed where inferred

Fault, dashed where inferred;
arrows indicate relative movemen

*Nomenclature of Scott and Bonk (1984).

Correlative units of Buesch and others (1996):
Caprock and upper cliff = crystal-rich member of Tiva Canyon Tu

Upper lythophysal = upper unit of crystal-poor member of Tiva Canyon Tuff

$\perp$ Drill hole and identification

Figure 9C. Generalized geologic section across Exile Hill and west-central Midway Valley. Location of section shown on plate 1. Datum is sea level. 


\section{Bow Ridge Fault}

The Bow Ridge fault is a north-trending, west-dipping normal fault that extends along the western base of Exile Hill and Bow Ridge near the western margin of Midway Valley (fig. 1). The fault is more than $10 \mathrm{~km}$ long and extends from bedrock exposures north of Midway Valley south to beyond Bow Ridge (Frizzell and Shulters, 1990; Day and others, 1998). Along much of its length, the fault is concealed beneath alluvium, but on the western edges of Bow Ridge and Exile Hill, it is exposed for short distances in bedrock. South of Bow Ridge, it bends abruptly southeast, follows the south margin of Bow Ridge, and may intersect the Paintbrush Canyon fault south of Fran Ridge in the Dune Wash area. Between Exile Hill and Bow Ridge, the fault was mapped by Day and others (1998) to split into three north-trending strands, with the westernmost strand shown to have down-tothe-east displacement (fig. 9B) and to extend north as a fault that connects short segments of faults displaying small downto-the-east offsets in bedrock at the east ends of ridges along the east side of Yucca Mountain. This western strand also is interpreted to be the eastern terminus of the northwest-trending strike-slip faults mapped in Drill Hole, Pagany, and Sever Washes (Day and others, 1998).

The Bow Ridge fault lies near the break in slope along the west side of Exile Hill (pl. 1). The fault is poorly expressed at the surface as several subtle and discontinuous west-facing diffuse scarps, but was exposed in five trenches (14, 14A-D) that were excavated along its trace at Exile Hill (figs. 1 and 2 ). In trenches $14 \mathrm{~A}$ and $14 \mathrm{~B}$, the fault is confined to bedrock and did not disturb overlying Quaternary deposits. Trenches 14C and 14D do not penetrate bedrock, but logs of the exposed surficial units show clear evidence of Quaternary fault activity (Menges and others, 1997). In trench 14, which was logged by Taylor and Huckins (1995), two colluvial wedges of middle to late Pleistocene age are in sharp contact with bedrock, but it is not known whether this is a fault contact or represents deposition against a bedrock fault scarp. In any case, no measurable offsets were observed within the surficial sequence in trench 14 with which to determine the magnitude and timing of individual faulting events during the Quaternary. A sixth trench, A/BR-3, was excavated across two subparallel photolineaments defined by a weak alignment of vegetation north of Exile Hill (pl. 1), and was logged as part of the present study (pl. 7).

Because they did not contribute information on Quaternary deformation, trenches $14 \mathrm{~A}$ and $14 \mathrm{~B}$ were not logged in detail. However, observations of the fault relations exposed in bedrock in trench 14A were made and are discussed in detail below.

In trench 14A, the Bow Ridge fault zone is about $2 \mathrm{~m}$ wide. The footwall block at the east end of the excavation is dark bluish-gray, clast-supported breccia within the crystalpoor member that forms the lower part of the Tiva Canyon Tuff; clasts range from less than $1 \mathrm{~mm}$ to as much as $30 \mathrm{~cm}$ in diameter (see Buesch and others (1996) for stratigraphic subdi- visions of the Tiva Canyon Tuff). This breccia is surrounded by silica-carbonate-filled fractures. Toward the west, a sharp fault contact separates the brecciated crystal-poor member of the Tiva Canyon Tuff from a narrow (width less than 0.5 m) band of reddish brown, moderately welded tuff distinctive of the upper $5 \mathrm{~m}$ of the crystal-rich member that forms the upper part of the Tiva Canyon Tuff. Another sharp fault contact separates the latter unit from a zone of highly sheared, very light gray to light brownish gray nonlithified tuff bounded by steeply west-dipping laminae of carbonate silica. The nonlithified tuff appears correlative with the nonwelded, pre-Rainier Mesa Tuff bedded tuff encountered in boreholes NRG-2A and -2B (Geslin and others, 1995). Carr (1992) noted that the petrography and mineral chemistry of a light-tan tuff from the Bow Ridge fault zone in trench 14A matched a sample of tuff "X" recovered from borehole RF-3 at a depth of $67 \mathrm{~m}$ (tuff "X" occurs between the pre-Rainier Mesa Tuff bedded tuff and the Tiva Canyon Tuff). Subvertical to east-dipping extensional fractures in the nonlithified tuff, some filled with carbonate, are consistent with down-to-the-west shear in the fault zone. The lithified Rainier Mesa Tuff is downdropped against preRainier Mesa Tuff bedded tuff across a narrow breccia zone containing a sharp, planar, steeply west-dipping fault (strike, N. $11^{\circ} \mathrm{W}$.; $\operatorname{dip} 86^{\circ} \mathrm{NW}$.). The entire fault zone, therefore, represents a west-facing sequence of downfaulted blocks that appears to include units ranging stratigraphically upward from the crystal-poor member in the lower part of the Tiva Canyon Tuff through the Rainier Mesa Tuff.

A minor fault, exposed at the west end of trench 14A, occurs on both walls as west-dipping fractures (strike, N. $8^{\circ}$ E.; dip, $75^{\circ}$ NW.) within the nonlithified Rainier Mesa Tuff. The lowest K-horizon of a soil formed in colluvium near the abrupt, gently westward sloping bedrock-colluvium contact appears to be displaced a maximum of about $15 \mathrm{~cm}$, down to the west. The fault is approximately aligned with a scarp at the contact between alluvium and the Rainier Mesa Tuff located about $25 \mathrm{~m}$ north of the trench. The total vertical displacement on this fault appears to be less than $5 \mathrm{~m}$.

The Bow Ridge fault was intersected in boreholes NRG-2 (50.2 $\mathrm{m}$ to $51.6 \mathrm{~m}$ ) and NRG-2B (70.8 to $79.2 \mathrm{~m}$ ) on the west side of Exile Hill (Buesch and others, 1994; Geslin and others, 1995; see fig. 9C). These picks define an average dip for the Bow Ridge fault of about $70^{\circ} \mathrm{W}$. between the boreholes. A dip of about $83^{\circ} \mathrm{W}$. is defined for the region between borehole NRG-2 and the surface trace of the fault, consistent with nearsurface fault attitudes measured in trenches 14 and 14A.

The dip separation of the contact between the crystal-rich and crystal-poor members of the Tiva Canyon Tuff across the Bow Ridge fault is about $130 \pm 5 \mathrm{~m}$. This estimate is based on detailed mapping of the contact on the west and east sides of Exile Hill, the pick for the contact at a depth of $74.1 \mathrm{~m} \mathrm{(243}$ $\mathrm{ft}$ ) in borehole NRG-2A (Geslin and others, 1995, p. 28), and other borehole data on the west side of the hill (pls. 1 and 3). Scott and Bonk (1984) and Day and others (1998) both show about $150 \mathrm{~m}$ of dip separation across the fault toward the south end of Midway Valley (figs. 9A and 9B). 
The behavioral characteristics and timing of Quaternary fault displacements on the Bow Ridge fault have been studied by Menges and others $(1994,1997)$ and Taylor and Huckins (1995), who described displacements that resulted from two to three middle to late Pleistocene faulting events observed in trench 14D on the west side of Exile Hill. Vertical displacements associated with individual surface-faulting events range from 1 to $46 \mathrm{~cm}$ with preferred values from 10 to $40 \mathrm{~cm}$ (Menges and others, 1997). Striations on carbonate laminae in the fault zone plunge $20^{\circ}-65^{\circ} \mathrm{SW}$., suggesting a component of left-lateral displacement; calculated values for net slip per event range from 11 to $70 \mathrm{~cm}$.

Dates of surface-faulting events on the Bow Ridge fault were derived by uranium-series and thermoluminescence analyses, tephrochronologic correlations, and soil-stratigraphic correlations to the alluvial stratigraphy of Midway Valley (Menges and others, 1997; Paces and others, 1994). These data indicate that the oldest recognized surface-faulting event in trench 14D occurred after deposition of a colluvial package ranging in age from greater than $350 \mathrm{ka}$ to greater than 700 $\mathrm{ka}$ and prior to deposition of colluvium with an associated soil dated as $234 \pm 47 / 35 \mathrm{ka}$. The most recent surface-faulting event occurred prior to deposition of an eolian cap having a TL age of $48 \pm 20 \mathrm{ka}$ (Menges and others, 1997). This estimate is consistent with the interpretation that the age of this event is closely associated with a basaltic ash-filled fracture in trench 14 (Taylor and Huckins, 1995) that is correlated with an eruption of the Lathrop Wells volcanic center, which is located 16 $\mathrm{km}$ southwest of Exile Hill and has been dated as $77 \pm 6 \mathrm{ka}$ (Heizler and others, 1999).

Trench A/BR-3 was excavated at a site that was purposely selected to assess the nature and origin of photolineaments along the projected trace of the Bow Ridge fault north of Exile Hill (fig. 10) (see Wesling and others, 1992). The trench is located on alluvial fan deposits that are similar in age to those at or near the surface in the prospective surface facilities site; the areal distribution of surficial units in the vicinity of the trench is shown in figure 10 . The lineaments, trending N. $10^{\circ}$ E. and N. $14^{\circ}$ E., are nearly coincident with the subsurface trace of the fault (Scott and Bonk, 1984; Day and others, 1998) and consist of alignments of creosote bushes commonly spaced about 5-10 m apart. A detailed map of the trench and descriptions of the exposed surficial units are shown in plate 7 (soil-profile descriptions are given in table A2 in the Appendix). The photolineaments were intersected between stations $38 \mathrm{~m}$ and $57 \mathrm{~m}$ on the $\log$, and the trace of the Bow Ridge fault as projected in the subsurface north of Exile Hill by Scott and Bonk (1984) is between stations $57 \mathrm{~m}$ and $63 \mathrm{~m}$.

No evidence was observed in trench A/BR-3 to indicate that any of the exposed deposits or soils (unit I=Qa3, unit $\mathrm{II}=\mathrm{Qa} 4$, unit III=Qa5) are displaced or otherwise deformed by faulting. To the contrary, the detailed mapping of sedimentary contacts and soil boundaries (pl. 7) clearly indicates an absence of faulting since the deposition of the unit-I alluvial-fan deposits (middle to late Pleistocene time), at least within the levels of resolution for detecting fault offsets, which depend on the sharpness, regularity, and linear extent of the key horizons being mapped. For three such horizons, these levels are (1) basal contact of unit II, less than $5 \mathrm{~mm}$ to $5 \mathrm{~cm}$; (2) soil $\mathrm{Sl}$, less than $5 \mathrm{~mm}$ to $10 \mathrm{~cm}$; and (3) bedding within unit I, less than $1 \mathrm{~cm}$ to $15 \mathrm{~cm}$. In particular, no evidence for rupturing of the exposed surficial deposits was observed between trench stations $35 \mathrm{~m}$ and $65 \mathrm{~m}$ (pl. 7), which includes that part of the excavation that intersected the two photolineaments and the subsurface projection of the Bow Ridge fault.

As discussed earlier, surficial deposits exposed in trench 14D indicate two to three middle to late Pleistocene faulting events along the Bow Ridge fault on the west side of Exile Hill. Because the same age deposits are not displaced in trench A/BR-3 (pl. 7), the conclusion is that the photolineaments and the projected trace of the Bow Ridge fault as mapped by Scott and Bonk (1984) are not coincident with the actual subsurface location of the fault. Either the late Quaternary movement on the fault dies out near the north end of Exile Hill, south of trench A/BR-3, or the fault trace lies either to the east or to the west of the trench, where it is not reflected in the youngest surficial deposits. Geophysical studies by Ponce (1993) and Ponce and Langenheim (1994) indicate that the bedrock trace of the Bow Ridge fault lies west of the trench site.

\section{Paintbrush Canyon Fault}

The Paintbrush Canyon fault strikes in a northerly direction, is west-dipping, and has down-to-the-west dip-slip displacement. From a point south of Busted Butte, it extends north along the east margin of Midway Valley near the base of Fran Ridge and Alice Ridge and dies out within the southern part of the Timber Mountain caldera north of Midway Valley (Frizzel and Shulters, 1990); it has a total length of approximately 23 $\mathrm{km}$. If the Stagecoach Road fault were included as the southern extension of the Paintbrush Canyon fault, as suggested by Whitney and Muhs (1991), its total length would be about $32 \mathrm{~km}$.

Exposures of the Paintbrush Canyon fault occur in bedrock north of Yucca Wash, along the west side of Fran Ridge south of Midway Valley, and locally in trenches and gullies. Frizzell and Shulters (1990) and Dickerson and Drake (1998) indicate that the fault is contained along a relatively narrow bedrock trace for the northernmost $11 \mathrm{~km}$ between Yucca Wash and the Timber Mountain caldera; little surficial cover occurs along this part of the fault.

Within Midway Valley, the Paintbrush Canyon fault is concealed beneath surficial deposits along its entire length, a distance of about $5 \mathrm{~km}$. Where buried by alluvium, its location is based on geophysical anomalies detected on aeromagnetic and electromagnetic surveys. Flanigan (1981), Hoover and others (1982), Bath and Jahren (1985), Frischknecht and Raab (1984), and Fitterman (1982) identify anomalies in resistivity and geoelectric data that are interpreted to coincide with the Paintbrush Canyon fault. Ponce (1993) and Ponce and Langenheim (1994) located the fault based on gravity and ground magnetic surveys (fig. 11). 


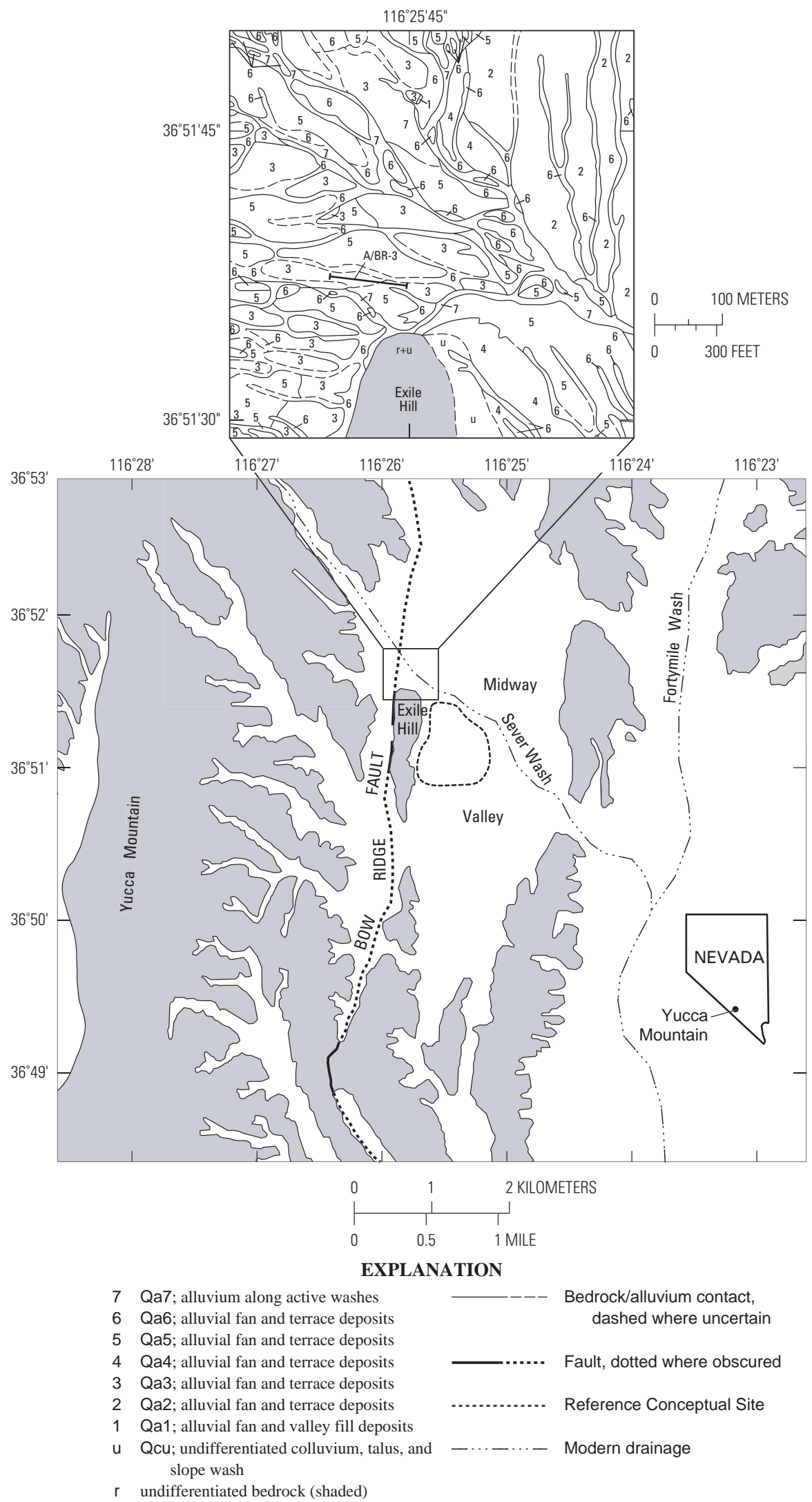

Figure 10. Maps showing location of trench A/BR-3 and surficial geology of surrounding area, based on Wesling and others (1992). 

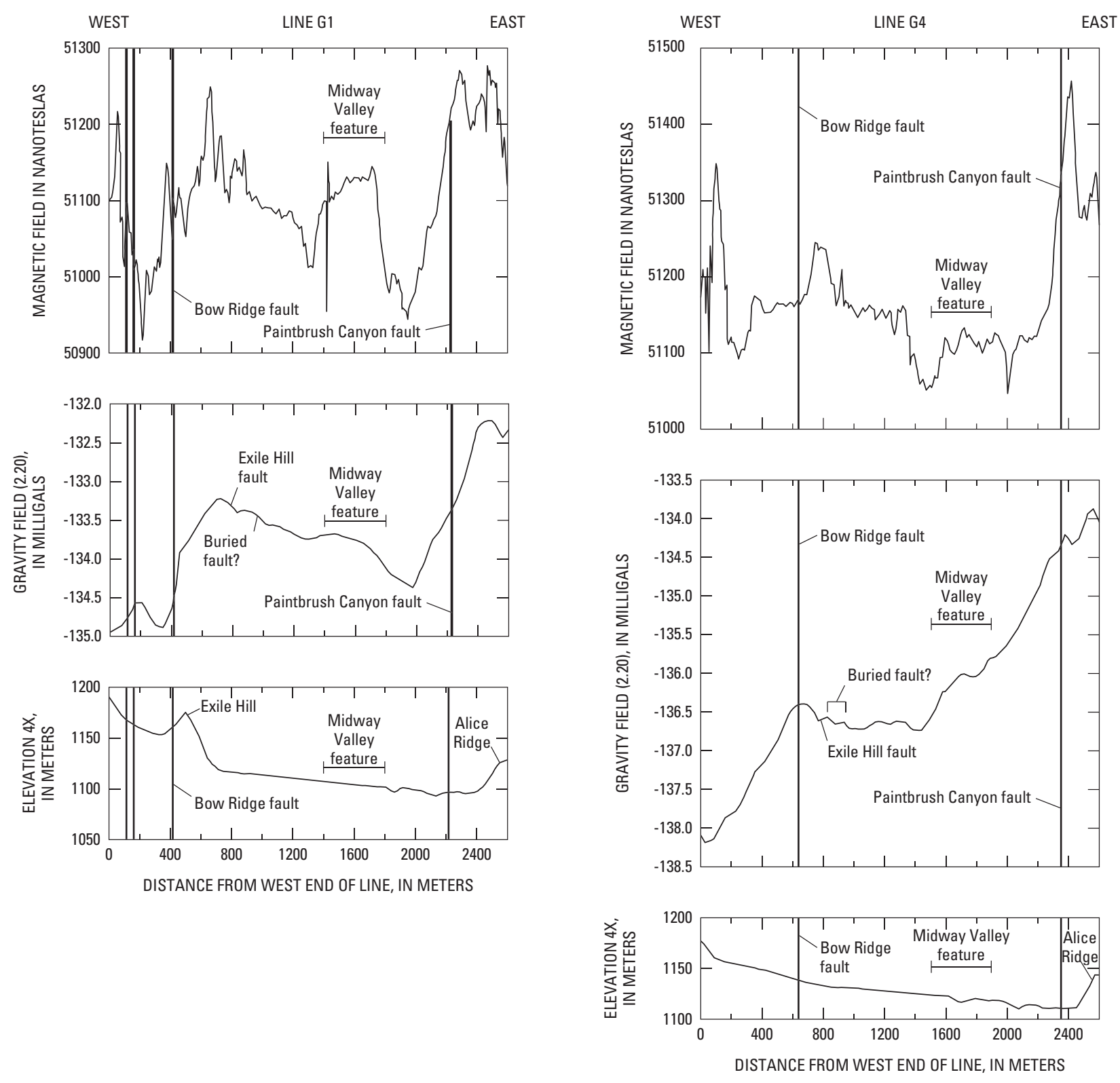

Figure 11. Results of gravity (Bouguer) and ground magnetic survey in Midway Valley (Ponce, 1993; Ponce and Langenheim, 1994). Survey lines shown on plate 3.

South of Midway Valley, the fault is exposed in bedrock for a distance of about $825 \mathrm{~m}$ along the west edge of Fran Ridge (fig. 1) (Day and others, 1998), but farther south it is entirely concealed by alluvium. The main fault trace apparently was intersected in borehole UE-25p \#1 at the southeast corner of Midway Valley (fig. 12). Combining the subsurface data with information from surface outcrops and exposures in trench MWV-T4, the average dip of the fault is approximately $70^{\circ} \mathrm{W}$. Abreast of Fran Ridge (northwest side), the Paintbrush Canyon fault is shown by Simonds and others (1995) and Day and others (1998) to split, with a western strand trending southwest and south along the west edge of a low hill where short segments are exposed in bedrock (fig. 1).

The total vertical displacement on the Paintbrush Canyon fault varies along its length; smaller total displacements lie to the north and larger ones to the south. Within the study area, total vertical dip-slip displacements on the fault generally are less than about $500 \mathrm{~m}$. North of Yucca Wash, the dip separation of the basal contact of the rhyolite of Comb Peak is about $230 \mathrm{~m}$, and oblique-slip offset in a direction parallel to slickensides that plunge $65^{\circ} \mathrm{S}$. is calculated to be $250 \mathrm{~m}$ (Dickerson and Spengler, 1994). Near the north end of Fran Ridge in 


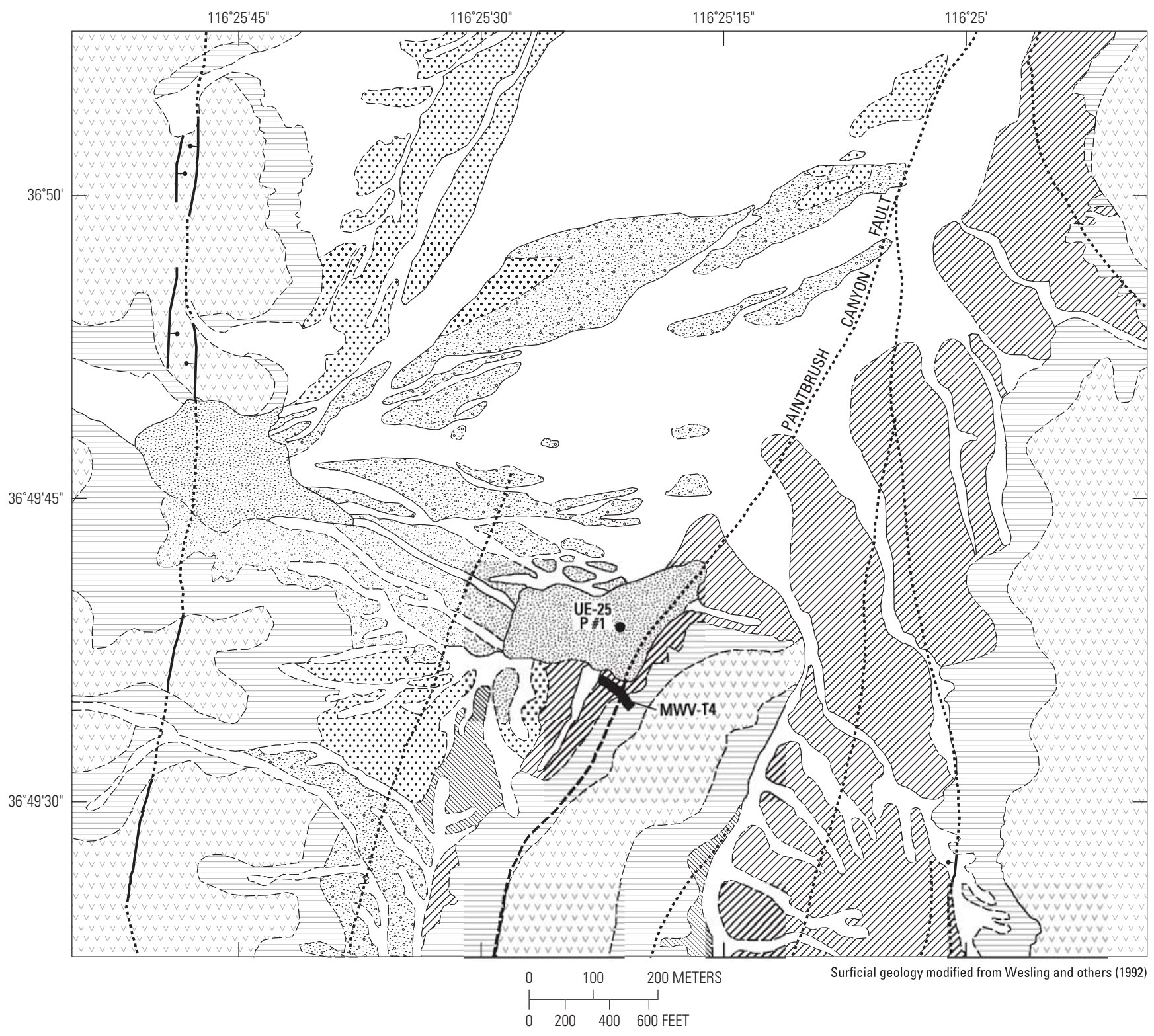

EXPLANATION
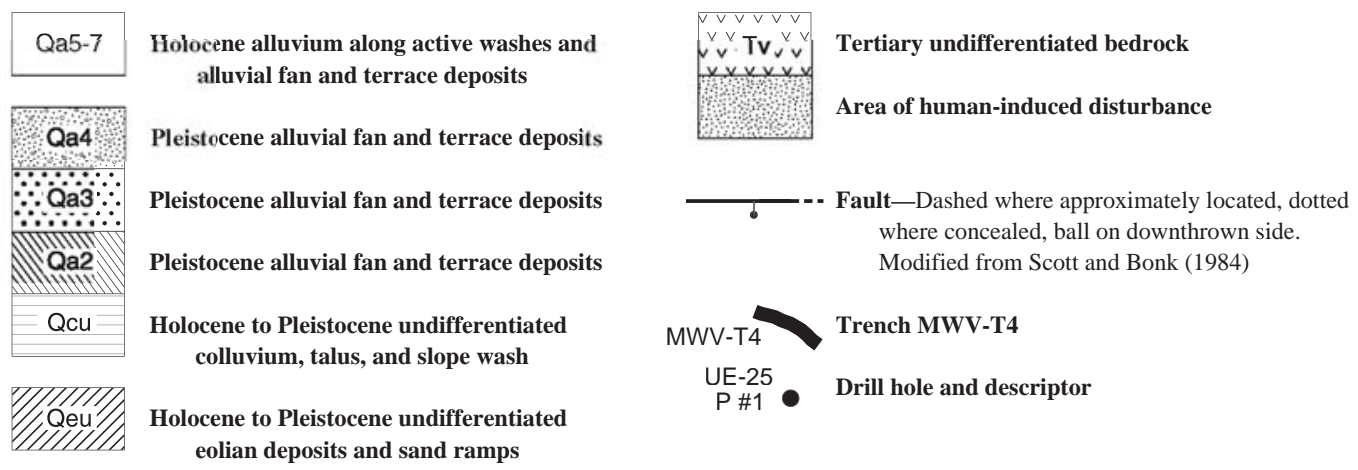

Figure 12. Surficial geologic map of southern Midway Valley, showing locations of trench MWV-T4 and borehole UE-25p \#1. 
Midway Valley, the dip separation of the top of the crystal-rich member of the Topopah Spring Tuff, as estimated from boreholes UE-25 WT-5 and UE-25 WT-14, is about $360 \mathrm{~m}$ (Scott and Bonk, 1984; Dickerson and Spengler, 1994). Day and others (1998) show the total dip-slip displacement of the crystal-rich member to be about $365 \mathrm{~m}$ across the main fault trace at the north end of Fran Ridge (fig. 9B).

Detailed paleoseismic studies of the Paintbrush Canyon fault have been conducted at three locations: (1) near the southern end of the fault and where it is exposed in deep gullies on the west side of Busted Butte, (2) in trench MWV-T4 in southern Midway Valley, and (3) in trench A1 in northern Midway Valley, north of Alice Ridge (fig. 1). Evidence of repeated middle to late Pleistocene surface-faulting events has been found at all three locations. Investigations at the first and third sites were conducted as part of a broad study of Quaternary faulting in the vicinity of Yucca Mountain (for example, see Menges and others, 1994). The results of investigations at trench MWV-T4 that were conducted during the present study are discussed below.

Trench MWV-T4 was excavated on northwest-sloping sand-ramp deposits across the western strand of the Paintbrush Canyon fault (figs. 1 and 12). Evidence of possible Quaternary faulting had been found by Swadley and others (1984) while mapping an earlier excavation (trench 17) at the site; that trench was then deepened in 1992 and redesignated trench MWV-T4. A map of the surficial geology of the southern part of Midway Valley is shown in figure 12.

Sand ramps, as the name implies, have a ramp-like geometry whereby the relatively planar to slightly convex surface of the landform slopes away from the bedrock hillslope. The deposits consist of undifferentiated eolian sand, colluvium, and minor fluvial sediments (unit Qeu, fig. 12). The surface of the sand ramp at trench MWV-T4 is characterized by a weakly to moderately developed desert pavement having some varnished clasts. The soil formed on this surface is moderately to strongly developed. No scarp is observed on the Qeu surface at the trench site, but there is an indistinct break in slope at about the same hillslope position as the fault.

A lineament identified on 1:60,000-scale infrared aerial photographs is coincident with the fault to the south of trench MWV-T4 (Wesling and others, 1992). However, to the north, the lineament diverges from the fault and trends to the west of the trench along a tonal contrast in alluvial-fan sediments. The lineament is described as a bedrock scarp and tonal contrast (Wesling and others, 1992). On larger scale (1:6,000 and $1: 12,000)$ aerial photographs, the southern part of the lineament appears to coincide with the uppermost reaches of small drainages that terminate at about the same hillslope position in a linear fashion along the trend of the hillslope. Subtle inflections and slope breaks were observed on colluvial wedges and sand-ramp surfaces between these drainages. This lineament can be traced to the trench on the larger scale aerial photographs.

One Tertiary bedrock unit and nine Quaternary stratigraphic units were identified within trench MWV-T4 (pl. 5; fig. 13). The principal stratigraphic units, which are numbered I through IX (oldest to youngest), are differentiated on the basis of their relative stratigraphic position, differences in the weathering and soil characteristics, the presence of major unconformities between them, and the results of numerical dating techniques that indicate age differences. These units are further subdivided into 16 subunits that are differentiated on the basis of grain size, color, cementation, soil profiles, geometry and distinctness of unit boundaries, and sedimentary features. Based on its primary mode of deposition, each subunit is classified as eolian/hillslope colluvium, fault-scarp-derived colluvium, or alluvium.

Detailed descriptions of the stratigraphic units are presented on plate 5 . The classification of the stratigraphic units and their correlation to the allostratigraphic units defined in Midway Valley by Wesling and others (1992) are presented in table 6 , and results of dating analyses of samples from various units are given in table 2 .

The zone of faulting exposed in trench MWV-T4 is approximately $14 \mathrm{~m}$ wide and dips steeply to the west (pl. 5). Some shears within the zone dip to the east. The zone of primary shearing is confined to the eastern $6 \mathrm{~m}$ of the zone, and minor secondary faults and fractures affect deposits as far as $8 \mathrm{~m}$ to the west of the primary traces. Deformation of the sand-ramp deposits appears to be primarily the result of down-to-the-west normal faulting on a steep, west-dipping fault. However, direct kinematic indicators of the direction of net slip were not found in the trench exposure, and some of the structural relations are consistent with a minor strike-slip component to the net slip.

Three main fault traces account for nearly all of the observed displacement of the Quaternary sediments; these are at about stations $1 \mathrm{~m}, 3 \mathrm{~m}$, and $6 \mathrm{~m}$ (pl. 5). The faulting below the unconformity at the base of unit VII at station $6 \mathrm{~m}$ is a nearly 1 -m-wide zone of closely spaced shears and fractures. Most of the shears have no detectable displacement, and nearly all of the down-to-the-northwest displacement of units VI and $\mathrm{V}$ (more than $1 \mathrm{~m}$ ) occurred along one of the less distinct shears within this zone. Except for some minor fractures that break units VIIa and VIIb, all of this displacement predates the erosional unconformity at the base of unit VII. Fractures and faults in the upper part of the zone have a variety of strikes and dips. The dominant orientation in the lower part of the exposure is N. $34^{\circ}$ E., dipping approximately $65^{\circ}$ E. Projection of this dip to the easternmost trace in the zone indicates that the fault traces coalesce at a depth of less than $10 \mathrm{~m}$.

The second main fault trace (near station $3 \mathrm{~m}$ ) juxtaposes units VIIb, V, and IV down on the northwest against units III and I along a northeast-trending shear that dips steeply (about $60^{\circ}$ ) to the southeast, giving the fault an apparent reverse sense of displacement. Repeated displacement along this trace is indicated by the decreasing amount of slip in successively younger strata. The cumulative apparent dip-slip displacement of unit IV is more than $1.8 \mathrm{~m}$. The displacement of unit VIIb is approximately $0.5 \mathrm{~m}$, which is the thickness of the scarpderived colluvial wedge. Faulting occurring after unit VIIb 


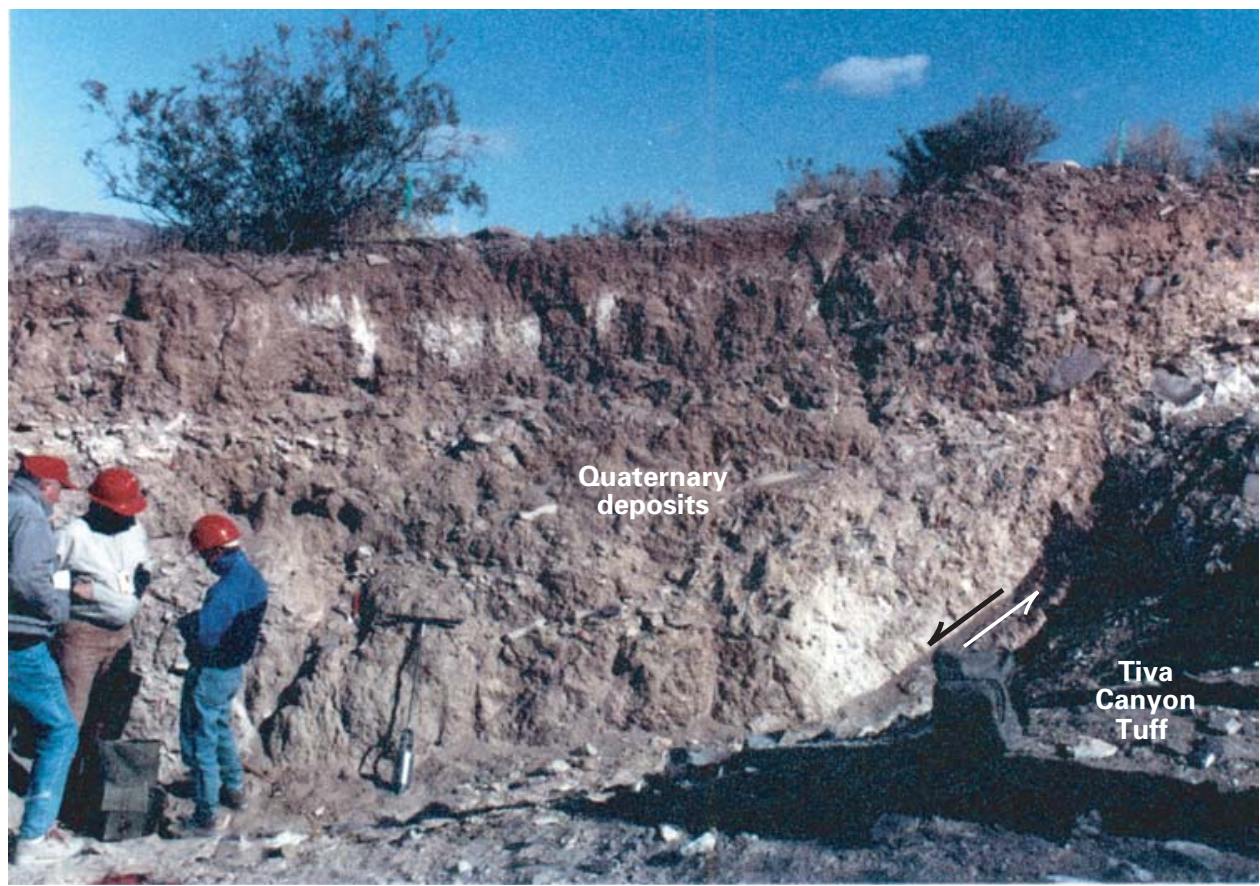

Figure 13. Quaternary eolian and colluvial deposits exposed in northeast wall of trench MWV-T4 faulted down against Tertiary Tiva Canyon Tuff along the Paintbrush Canyon fault (between arrows showing relative movement).

Table 6. Correlation of stratigraphic units in trench MWV-T4 with allostratigraphic units in Midway Valley.

[ka, thousand years before present; >, greater than; <, less than; $\leq$, less than or equal to; Do., ditto; --, none]

\begin{tabular}{|c|c|c|c|c|}
\hline \multicolumn{3}{|c|}{ Trench MVW-T4 } & \multirow{2}{*}{$\begin{array}{l}\text { Correlative allostratigraphic unit in } \\
\text { Midway Valley }\end{array}$} & \multirow[t]{2}{*}{ Age } \\
\hline & Stratigraphic unit & Numerical age' (ka) & & \\
\hline$\underline{\text { Unit IX }}$ & - Scarp-derived colluvium & $>6$ to $<38$ & Qa5 & $\begin{array}{l}\text { late Pleistocene to } \\
\text { early Holocene }\end{array}$ \\
\hline$\underline{\text { Unit VIII }}$ & - Eolian sand/colluvium & $\leq 38$ to $<73$ & Qa4 & late Pleistocene \\
\hline$\underline{\text { Unit VII }}$ & - Scarp-derived colluvium & $\leq 73$ to $\leq 130^{3}$ & Qa3 & $\begin{array}{l}\text { middle to late } \\
\text { Pleistocene }\end{array}$ \\
\hline$\underline{\text { Unit VI }}$ & - Eolian sand/colluvium & $>140$ & Qa3 & middle Pleistocene \\
\hline$\overline{\text { Unit V }}$ & - Eolian sand/colluvium & $>400$ & Qa3 or Qa2 & Do. \\
\hline$\underline{\text { Unit IV }}$ & - Colluvium & -- & Qa2 (?) & $\begin{array}{l}\text { early to middle } \\
\text { Pleistocene }\end{array}$ \\
\hline$\underline{\text { Unit III }}$ & - Scarp-derived(?) colluvium & -- & Qa2 (?) & Do. \\
\hline$\underline{\text { Unit II }}$ & - Colluvium & $>400$ & Qa2 & Do. \\
\hline$\underline{\text { Unit I }}$ & - Eolian sand/colluvium & $>600(?)$ & -- & early Pleistocene \\
\hline$\underline{\mathrm{TV}}$ & - Tertiary volcanic bedrock & -- & -- & middle Miocene \\
\hline
\end{tabular}

${ }^{1}$ See table 2 .

${ }^{2}$ Wesling and others, 1992.

${ }^{3}$ Maximum estimated age for basal unconformity, based on TL date of approximately $70 \mathrm{ka}$ (TL-03, table 2) for subunit VIIe plus an estimated combined time interval of $60 \mathrm{k} . \mathrm{y}$. or less represented by the lack of significant soil development on each of two underlying units (VIIc and VIIb, pl. 5). 
is indicated by the sharp contact between units VIIb and III and the rotation of elongated clasts parallel to the fault. Also, secondary fractures on the downthrown side of the fault cut this unit. Unit VIIc appears to be in depositional contact with unit III where it crosses this trace; the height of the buried scarp defined by this contact is approximately $0.5 \mathrm{~m}$. No evidence that displacement took place along this trace after deposition of unit VIIc was observed. A fracture having no detectable displacement splays off of this trace and ruptures units Ia, III, VII, and VIII. This fracture formed during the most recent event on the easternmost fault trace.

The easternmost fault trace is located at about station 1 $\mathrm{m}$ (pl. 5). Faulting on this trace occurs in a discrete zone of shearing less than $5 \mathrm{~cm}$ wide, where volcanic bedrock (Tv) is juxtaposed against older colluvium (units I and III). The fault, which strikes N. $46^{\circ}$ E. and dips $78^{\circ} \mathrm{NW}$., bifurcates upward into four or five splays in the upper part of the trench. The cumulative displacement along this trace progressively diminishes in the younger units, providing direct evidence of the two most recent surface-faulting events, which postdate deposition of unit VIIc. The apparent dip-slip displacement of unit III is 0.6 to $0.7 \mathrm{~m}$ down to the west, which is consistent with the thickness of the scarp-derived colluvial wedge from the second-most-recent surface-faulting event (unit VIIe). Unit VIIe is faulted, and the ruptures extend upward through the overlying eolian sand/colluvium (unit VIIIb) but not into unit IX. The apparent vertical displacement of unit VIIIb during the most recent surface-faulting event is $0.2 \mathrm{~m}$, which is the height of the buried fault scarp defined by the contact between unit VIIIb and the colluvium (unit IX) deposited after the most recent faulting event. The apparent down-to-the-west displacement indicated by the scarp relations appears to be inconsistent with the absence of any down-to-the-west displacement on the base of unit VIIIb. To the contrary, the base of unit VIIIb has an apparent down-to-the-east displacement of approximately $3-5 \mathrm{~cm}$. This inconsistency is readily explained if there is a left-lateral component to the net slip. Based on the exposure in the opposite wall of the trench, the basal contact of unit VIIIb has an average dip of more than $35^{\circ}$ to the southeast. Oblique slip having a left-slip component of less than $35 \mathrm{~cm}$ and a dip-slip component (down-to-the-west) of $20 \mathrm{~cm}$ would produce an apparent up-to-the-west 5-cm displacement of the southeast-dipping basal contact. The cross-sectional pattern of faulting where the shears bifurcate upward and flatten toward the footwall side of the fault, which is not typical of normal faults, also indicates a lateral component to the net slip.

Secondary deformation within trench MWV-T4 includes minor faulting and fracturing over a $14-\mathrm{m}$-wide zone that is almost entirely on the downthrown side of the fault. Secondary faulting was associated with at least three earlier events. Based on the mapped upward extent of the fractures, faulting occurred during the following intervals: (1) post-units V-VI and pre-unit VII; (2) post-units VIIa and VIIb and pre-unit VIIc; and (3) post-unit VIII and pre-unit IX. With the exception of the most recent event, all scarp-derived colluvial wedges have been affected by minor shears or fractures (pl. 5).
Fractures during the most recent faulting event were limited to a 3-m-wide zone.

The largest amount of deformation associated with secondary faulting is relatively small; one shear at station $7 \mathrm{~m}$, for example, displaces the scarp-derived colluvial wedge (the base of unit VIIa) less than $10 \mathrm{~cm}$ down on the east. However, most of the secondary shears and fractures had no detectable displacement.

Geologic data from trench MWV-T4, as well as from borehole UE-25p \#1 (fig. 12), indicate that there has been a long history of Quaternary faulting on the Paintbrush Canyon fault. The contact between the Tertiary bedrock and the overlying sequence of alluvial, colluvial, and eolian deposits on the footwall block is exposed in the trench (pl. 5) and also is encountered on the hanging-wall block at about a depth of 39 $m$ in borehole UE-25p \#1(Muller and Kibler, 1984). A fault was encountered in the borehole at a depth of $81 \mathrm{~m}$. These data indicate that the average slope of the bedrock surface is about $45^{\circ}$ to the northwest, and the average dip of the fault is about $65^{\circ}$ to the northwest. These relations indicate that there may be $45 \mathrm{~m}$ or more of vertical separation of the contact between bedrock and the overlying sediments. The history of only the last few meters of this displacement, however, is exposed in the wall of trench MWV-T4 (pl. 5). Stratigraphic and structural relations indicate at least three, and probably four, surfacefaulting events during the late Pleistocene (within approximately the past 130 k.y.). Earlier faulting is indicated by the greater amounts of deformation and larger displacements of the older stratigraphic units relative to the younger units.

Because of uncertain correlations among some of the older surficial units exposed in trench MWV-T4, the history of early to middle Pleistocene faulting and the magnitude of individual events are difficult to determine. However, it appears that the intense shearing and faulting of the oldest exposed eolian/colluvial sand-ramp deposits (unit I), which dip at least $45^{\circ}$ to the east, represent a long history of deformation. A U-series date (table 2) indicates that these deposits may be more than $600 \mathrm{ka}$. Most of the deformation of unit I predates the angular unconformity that separates this unit from the overlying sediments (units II, III, IV, and V), which are more than $400 \mathrm{ka}$.

Before unit III was deposited, unit II was completely eroded between stations $1 \mathrm{~m}$ and $3 \mathrm{~m}$ on the hanging-wall block, forming a fault-line scarp, or channel margin, against which unit III was deposited (pl. 5). On the easternmost trace (between stations 0 and $1 \mathrm{~m}$ ), the apparent vertical separation between units II and III is similar to that associated with the two most recent faulting events. A small wedge of unit III is preserved in the footwall block above and inset into unit II. Restoration of the section by backing out the displacement from the two most recent events leaves no vertical separation available to produce the scarp against which unit III was deposited. The elevation of the bedrock/unit I contact appears to be fairly uniform across the width of the trench, and it seems unlikely that lateral displacement during the two most recent events could produce these relations. Therefore, unit III may 
have been deposited in a channel that was eroded along the trace of the fault. Alternatively, unit III may be a scarp-derived colluvial wedge from the earlier phase of faulting. In this case, unit Ia is probably equivalent to unit II. Unit Ia has a strongly developed K horizon similar in appearance to unit II. Faulting on the easternmost fault strand has progressively rotated unit I. An event on this strand prior to the two most recent faulting events may have resulted in deposition of unit III, in which case the unit would represent a scarp-derived colluvial wedge. This scenario is simpler than a model in which unit II is absent from the footwall block (between stations $1 \mathrm{~m}$ and 3 $\mathrm{m}$ ) owing to erosion and deposition against a fault-line scarp. However, the correlation of unit I with unit II is problematic. Unit I contains opaline silica layers that are approximately 5 $\mathrm{cm}$ thick, whereas unit II contains opaline silica layers only as much as $0.5 \mathrm{~cm}$ thick.

Following deposition of unit III, faulting occurred on the primary fault at station $3 \mathrm{~m}$ and possibly along the western trace at station $6 \mathrm{~m}$ (pl. 5). Unit III is not exposed in the trench on the downthrown side west of station $3 \mathrm{~m}$. The vertical displacements on these traces were large enough to fault unit III beneath the level of the trench floor, where it presumably occurs. Alternatively, lateral slip along the trace at station $3 \mathrm{~m}$ may have moved unit III out of the plane of section (the trench wall) on the downthrown side of this trace. In either case, one or more events along this trace occurred sometime after the deposition of unit III and before the deposition of unit VII. The gravelly nature of unit IV indicates it is a scarp-derived colluvial wedge associated with this older phase of faulting; however, this faulting is not certain because of the limited exposure of the unit.

Unit V was deposited during a period of eolian activity. Its reddish hue indicates that some soil may have developed after the sand was deposited. Alternatively, unit V may have been derived from the reworking of the upper parts of the $S_{I I}$ and $S_{\mathrm{III}}$ soils. Uranium-series dates on secondary carbonate from unit $\mathrm{V}$ indicate that these deposits are more than $400 \mathrm{ka}$. Because unit $\mathrm{V}$ contains a greater concentration of fractures than does unit VI, faulting may have occurred after the deposition of unit $\mathrm{V}$ and before the deposition of unit VI. However, the stratigraphic and structural relations do not require an event during this interval, and the greater density of fractures in unit $\mathrm{V}$ may simply be owing to its position relative to the main fault traces.

Unit VI is an eolian sand/colluvial hillslope deposit ( $\left.\mathrm{VI}_{1}\right)$ that interfingers with alluvium $\left(\mathrm{VI}_{2}\right)$ to the west of the fault. This unit overlies unit $\mathrm{V}$ and is not preserved to the east of station $6 \mathrm{~m}$. Uranium-series dates on secondary carbonate from unit VI indicate that the sediments are more than $140 \mathrm{ka}$. The abrupt upper contact of the unit and the lack of pedogenesis indicate that very little time separates deposition of this unit and the sequence of late Pleistocene scarp-derived colluvial wedges (unit VII).

In summary, the number and size of fault ruptures during the early to middle Pleistocene (faulting that predates unit VII) is uncertain. The intense deformation and tilting of unit
I probably represents a long history of displacement, most of which is not represented in the trench exposure. After the deposition of unit I and before that of unit VII, at least two, and possibly more, episodes of faulting are indicated by larger displacements of the older units compared to the late Pleistocene units - this is also indicated by the faulting and secondary shears in units IV, V, and VI. Faulting during this period probably occurred intermittently during the formation of the soils on units II and III and continued after the deposition of unit V. Uranium-series dates on secondary carbonate from these units indicate they are all more than $400 \mathrm{ka}$ (table 2). Alluvium and eolian/colluvial sand-ramp deposits (unit VI), which are more than $140 \mathrm{ka}$, continued to accumulate on the hillslope, and at least one surface-faulting event postdates these deposits and predates the erosional unconformity at the base of unit VII.

An erosional unconformity separates units III, V, and VI from the overlying sequence of scarp-derived colluvial wedges and eolian/colluvial hillslope deposits (units VII, VIII and IX). The base of unit VII is estimated to be less than $130 \mathrm{ka}$ (table 6). Based on the stratigraphic and structural relations exposed in trench MWV-T4, there have been at least three and probably four late Pleistocene surface-faulting events on the western strand of the Paintbrush Canyon fault. Conceivably, the colluvial wedges associated with the fourth- and thirdmost-recent events described below resulted from a single event. However, the preferred interpretation is that there have been four discrete late Pleistocene events.

The scarp-derived colluvial wedge at the base of unit VII (units VIIa and VIIb) is interpreted to represent material that was eroded from the scarp produced by the fourth-mostrecent event, which was associated with about $0.5 \mathrm{~m}$ of vertical displacement on the middle primary fault trace (at station $3 \mathrm{~m}$ ). The geometry of these units indicates that they might represent two separate wedges formed by different events, but there is no other confirming evidence. On the contrary, the step in the basal unconformity of unit VII, which coincides with the westernmost primary fault trace (at station $6 \mathrm{~m}$ ), seems to be due to erosion and not to burial of a fault scarp. Therefore, units VIIa and VIIb are interpreted to be colluvium from the same event.

There was no large amount of soil development on units VIIa or VIIb prior to their burial by the next scarp-derived colluvium (unit VIIc). Therefore, the interval between the fourthand third-most-recent events is inferred to have been less than about $30 \mathrm{k} . \mathrm{y}$., which is the amount of time considered necessary for soil development based on TL dates for soils $S_{\mathrm{VIII}}$ and $\mathrm{S}_{\text {VII }}$ (see table 2).

The third-most-recent event occurred along the same trace as the previous event. Unit VIIb was displaced down on the northwest about $0.5 \mathrm{~m}$, and secondary faults and fractures cut units VIIa and VIIb (between stations $3 \mathrm{~m}$ and 10 m). Scarp-derived colluvium (unit VIIc) was deposited on the downthrown side of the fault and buried the scarp that was produced by this event.

Units VIIa, VIIb, and VIIc might represent a normal depositional sequence resulting from a single event, but the pre- 
ferred interpretation is that VIIb is a scarp-derived colluvial wedge produced after a separate surface-faulting event. The back edge of unit VIIb, adjacent to the fault, appears to have been faulted as is indicated by rotated clasts that are aligned along the same trend as the fault and by a secondary fault and fractures that appear to rupture units VIIa and VIIb but not unit VIIc. These observations strongly indicate that there were two late Pleistocene displacements on this trace of the fault.

After deposition of the scarp-derived colluvium from the third-most-recent event (unit VIIc), eolian/colluvium hillslope deposits accumulated near the base of the hillslope (unit VIId), but no significant soil developed on units VIIc or VIId before their burial by the next scarp-derived colluvium (unit VIIe). Therefore, the interval between the third- and second-mostrecent events also is inferred to have been less than about 30 k.y.

The second-most-recent surface-faulting event occurred on the easternmost trace of the Paintbrush Canyon fault (between stations 0 and $1 \mathrm{~m}, \mathrm{pl} .5$ ). This event produced an approximately 0.5 - to 0.7 -m-high fault scarp that subsequently was buried by scarp-derived colluvium (unit VIIe). A TL date from unit VIIe indicates that this event probably occurred about $70 \mathrm{ka}$ (TL-03, table 2).

Following deposition of the scarp-derived colluvium associated with the second-most-recent surface-faulting event, the hillslope was stable long enough to form a moderately well developed soil (soil $\mathrm{S}_{\mathrm{VII}}$ ) having stage-I+ carbonate/silica morphology. During this period of general slope stability, an alluvial channel was cut at the base of the hillslope and backfilled with alluvium (unit VIIf). Later, unit VII and the $S_{\mathrm{VII}}$ soil were truncated by erosion that cut a broad channel that is filled with a thin layer of alluvium (unit VIIIa) and eolian/ colluvial hillslope deposits (unit VIIIb). A TL date indicates that unit VIIIb was deposited approximately $38 \mathrm{ka}$ (TL-04, table 2). Following or concurrent with deposition of this eolian/colluvial deposit, the hillslope was sufficiently stable to allow the development of a soil (soil $\mathrm{S}_{\mathrm{VIII}}$ ) having a strongly developed Bt horizon.

The most recent faulting event, which displaces unit VIIIb and soil $\mathrm{S}_{\mathrm{VIII}}$, occurred along the easternmost trace (station 0 $\mathrm{m}, \mathrm{pl} . \mathrm{5}$ ) and produced a scarp about $20 \mathrm{~cm}$ high. Secondary fractures occurred over a 3-m-wide zone on the downthrown side of the fault. The apparent dip-slip displacement associated with this event was therefore $20 \mathrm{~cm}$, and there was probably a lateral component to the net slip.

Unit IX, which is undisplaced, thickens across the nowburied fault scarp (between stations $0.5 \mathrm{~m}$ and $1.5 \mathrm{~m}$ ). The gravelly facies in this unit immediately above the fault represents the debris-slope colluvial facies that was deposited following the most recent surface-faulting event. A weakly to moderately developed soil (soil $\mathrm{S}_{\mathrm{IX}}$ ) has formed on these deposits, which indicates they are latest Pleistocene or early Holocene in age.

Fault displacement data for the late Pleistocene surfacefaulting events are summarized in table 7. Except for the displacement associated with the most recent event, cumulative displacements were determined by measuring the vertical separation between the projections of the base of the displaced unit and (or) scarp-derived colluvial wedge on the downthrown side to the easternmost fault trace and the projection of the top of unit II on the upthrown side of the fault. Irregularities in these contacts create uncertainties in the projected intersections of the displaced contacts with the fault. The vertical displacement associated with the most recent event is estimated to be $20 \mathrm{~cm}$, based on the apparent vertical displacement of the top of unit VIII across the easternmost fault trace. Because of the steep dip of the fault, the vertical displacements presented on table 7 are essentially the same as the dip-slip displacement.

Table 7. Summary of fault displacement data for trench MWV-T4 in southern Midway Valley.

[m, meter; --, no data]

\begin{tabular}{ccccc}
\hline Faulting event & $\begin{array}{c}\text { Scarp-derived colluvial } \\
\text { wedge (plate 5) }\end{array}$ & $\begin{array}{c}\text { Maximum thickness of } \\
\text { wedge }(\mathrm{m})\end{array}$ & $\begin{array}{c}\text { Cumulative vertical } \\
\text { displacement }(\mathrm{m})\end{array}$ & $\begin{array}{c}\text { Estimated displacement } \\
\text { per event }(\mathrm{m})\end{array}$ \\
\hline 1st (most recent) & IX & -- & $0.20^{2}$ & 0.20 \\
2nd & VIIe & 0.7 & $0.82 \pm 0.15^{3}$ & $0.62 \pm 0.15$ \\
3rd & VIIc & 0.5 & $1.8 \pm 0.3^{4}$ & $0.98 \pm 0.45$ \\
4th & VIIa \& VIIb & 0.5 & $2.2 \pm 0.5^{5}$ & $0.0-1.4$ \\
& \multicolumn{2}{c}{ Average vertical displacement per event } & $0.55 \pm 0.1^{6}$ \\
\hline
\end{tabular}

\footnotetext{
${ }^{1}$ Measured by projecting contacts to the plane of the easternmost fault trace; apparent vertical separation and dip slip are essentially the same; net slip may include a component of lateral slip (see discussion in text).

${ }^{2}$ Vertical displacement of buried surface; top of unit VIII.

${ }^{3}$ Thickness of colluvial wedge from second-most-recent event (unit VIIe) plus vertical displacement associated with the most recent event; equivalent to vertical displacement between the base of unit VIIe on downthrown side and the top of unit II on upthrown side.

${ }^{4}$ Vertical displacement between the base of unit VIIc on downthrown side and the top of unit II on upthrown side.

${ }^{5}$ Vertical displacement between the base of unit VII on downthrown side and the top of unit II on upthrown side.

${ }^{6}$ Assumes there have been four late Pleistocene surface-faulting events; if there were only three events, the average vertical displacement per event is $0.73 \pm 0.17 \mathrm{~m}$.
} 
The vertical displacement associated with individual faulting events was calculated by subtracting the cumulative displacement from the previous events from the cumulative displacement of the displaced unit. Taking into account the uncertainty in the measurements, there is generally good agreement between the calculated displacements associated with the individual surface-faulting events and the thickness of the corresponding scarp-derived colluvial wedge (table 7). The vertical displacements range from 0.20 to about $1.4 \mathrm{~m}$.

The average displacement per event was calculated dividing the total displacement by the number of events. The unconformity at the base of unit VII is displaced $2.2 \pm 0.5 \mathrm{~m}$. This displacement probably was the result of four events, in which case the average vertical displacement is $0.55 \pm 0.1 \mathrm{~m}$ per event. If the displacement was produced by only three events, the average vertical displacement would be $0.73 \pm 0.17 \mathrm{~m}$ per event.

For other exposures of the Paintbrush Canyon fault, C.M. Menges (written commun., 1996) reported that (1) at a locality on the west side of Busted Butte $(5 \mathrm{~km}$ south of trench MWV-T4), individual event displacements and cumulative net displacements are $0-2.46 \mathrm{~m}$ and greater than or equal to 5.45-7.96 m, respectively; and (2) in trench A-1 north of Alice Ridge (fig. 1), the values for individual and net displacements are $0-0.44 \mathrm{~m}$ and greater than $1.45-1.70 \mathrm{~m}$.

Table 8 summarizes the late Quaternary slip-rate data. The cumulative vertical displacement associated with the two most recent events and the TL date from unit VIIe, which was deposited immediately following the second-most-recent faulting event, indicate a slip rate of about $0.011 \pm 0.004 \mathrm{~mm} / \mathrm{yr}$. Because this is the average of only two events, this value is not considered to be very reliable, particularly considering that the most recent event appears to have been anomalously small.

Minimum and maximum slip-rate values can be calculated based on the inferred maximum age of the unconformity at the base of unit VII and the minimum age for unit VI. The cumulative displacements and ages of these horizons indicate that the slip rate is in the range of more than 0.013 and less than $0.025 \mathrm{~mm} / \mathrm{yr}$ (table 8). The TL age for unit VIIe indicates that the average slip rate is probably in the low end of this range, even if one hypothetically increases the cumulative displacement to allow for the small displacement associated with the most recent event. Taking these factors into consideration, the average late Quaternary slip rate (vertical displacement) on the Paintbrush Canyon fault at the trench MWV-T4 locality is estimated to be $0.017+0.008 /-0.004$ $\mathrm{mm} / \mathrm{yr}$. In comparison, fault slip rates at the Busted Butte exposure (cited above) and in trench A-1 were estimated by C.M. Menges (written commun., 1996) to be 0.001-0.01 $\mathrm{mm} / \mathrm{yr}$ and $0.001-0.004 \mathrm{~mm} / \mathrm{yr}$, respectively.

Stratigraphic and structural relations associated with the most recent event are consistent with normal-left-oblique slip, but the amount of lateral slip is not well constrained (no slickensides observed). The orientation of slickensides mapped by Scott and Bonk (1984) along the Paintbrush Canyon fault and other north-south faults in the vicinity of Yucca Mountain, however, indicate fault movements that range from nearly pure dip slip to movements having an aspect ratio of about 3:1 (lateral:vertical) with an average aspect ratio of 1:1. Assuming an aspect ratio of $1: 1$, the net slip would be 1.4 times the vertical displacement.

The average long-term (post-middle Miocene) slip rate on the Paintbrush Canyon fault can be estimated using Scott and Bonk's geologic section A-A' (1984, sheet 2), which passes through borehole UE-25p \#1. On the basis of the information presented on that section, the vertical displacement of the Tiva Canyon Tuff of the Paintbrush Group is estimated to be $230 \pm 20 \mathrm{~m}$. The Tiva Canyon Tuff is $12.7 \mathrm{Ma}$ (Sawyer and others, 1994). These values indicate an average long-term slip rate of $0.018 \mathrm{~mm}$ per year, which is essentially the same as the average late Quaternary slip rate of $0.017+0.008 /-0.004$

Table 8. Late Quaternary fault slip rate data for trench MWV-T4 in southern Midway Valley.

[ka, thousand years before present; $\mathrm{m}$, meters; mm/yr, millimeters per year; <, less than; >, more than]

\begin{tabular}{cccc}
\hline $\begin{array}{c}\text { Displaced datum } \\
\text { (plate 5) }\end{array}$ & $\begin{array}{c}\text { Approximate age } \\
(\mathrm{ka})\end{array}$ & $\begin{array}{c}\text { Cumulative vertical } \\
\text { displacement }(\mathrm{m})\end{array}$ & $\begin{array}{c}\text { Slip rate } \\
(\mathrm{mm} / \mathrm{yr})\end{array}$ \\
\hline $\begin{array}{c}\text { VIIe }^{1} \\
\text { Unconformity at base of } \\
\text { unit VII }\end{array}$ & $\begin{array}{c}23 \pm 9 \\
\text { Base of unit } \mathrm{VI}^{3}\end{array}$ & $0.82 \pm 0.15$ & $0.011 \pm 0.004$ \\
& $>130$ & $2.2 \pm 0.5$ & $>0.013$ \\
& Estimated late Quaternary slip rate & $3.0 \pm 0.5$ & $<0.025$ \\
\end{tabular}

\footnotetext{
${ }^{1}$ Thickness of colluvial wedge from second-most-recent event (unit VIIe) plus vertical displacement associated with the most recent event; equivalent to vertical displacement between base of unit VIIe on downthrown side and top of unit II on upthrown side.

${ }^{2}$ Vertical displacement between the base of unit VII on downthrown side if fault and the top of unit II on upthrown side.

${ }^{3}$ Vertical displacement between the base of unit VI on downthrown side of fault and the top of unit II on upthrown side.
} 
$\mathrm{mm} / \mathrm{yr}$, on the basis of data from trench MWV-T4.

Two approaches were used to estimate the average recurrence interval for surface-faulting events. One approach uses the stratigraphic record of individual late Pleistocene faulting events. The ages of various stratigraphic intervals are divided by the number of surface-faulting events represented during that time interval (table 9). On the basis of event stratigraphy, the average interval between surface-faulting events on the Paintbrush Canyon fault at trench MWV-T4 is estimated to be $37 \pm 5$ k.y. In the other approach, the average displacement per event $(0.55 \pm 0.1 \mathrm{~m}$, table 7$)$ is divided by the late Quaternary slip rate $(0.017 \pm 0.008 / 0.004 \mathrm{~mm} / \mathrm{yr}$, table 8$)$ to calculate an average recurrence interval of 32 $\pm 18 / 14$ k.y. Combining values from the two approaches indicates an average recurrence interval of $35 \pm 15$ k.y. for surface-faulting events on the Paintbrush Canyon fault at trench MWV-T4. Based on available age control, estimated average recurrence intervals between events on the Paintbrush Canyon fault at the Busted Butte locality and in trench A-1 were computed by C.M. Menges (written commun., 1996) to be 30-270 k.y. and 50-145 k.y., respectively.

The actual time intervals between successive events are not well constrained. Differences in the degree of soilprofile development on colluvial sediments that were deposited between the surface-faulting events indicate that the late Pleistocene events did not occur at uniform intervals. No soils have formed on scarp-derived colluvial wedges associated with the fourth-most-recent event (unit VIIa/VIIb) and the thirdmost-recent event (unit VIIc). The minor accumulation of carbonate (stage-I carbonate morphology) in these colluvial deposits appears to be related to the formation of soil $\mathrm{S}_{\mathrm{VII}}$ on unit VIIe. The lack of a well-developed soil on these scarp-derived colluvial wedges indicates that the interval separating the fourth- and third-most-recent events and the interval between the third- and second-most-recent events were relatively short, perhaps less than 15 to $10 \mathrm{ka}$, and certainly less than $30 \mathrm{ka}$. These intervals are in marked contrast to the interval between the second-most-recent event and the most recent event, where there was sufficient time for (1) formation of the soil $\mathrm{S}_{\mathrm{VII}}$, (2) erosion of a fault-line channel (unit VIIIa), (3) deposition of eolian/colluvial hillslope deposits (unit VIIIb), and (4) formation of soil $\mathrm{S}_{\mathrm{VIII}}$. This all occurred after deposition of unit VIIc and before deposition of unit IX. Based on the TL date from unit VIIe (73 $\pm 9 \mathrm{ka})$ and an inferred age of $10 \pm 5 \mathrm{ka}$ for unit IX (latest Pleistocene to early Holocene), the interval between the two most recent events is estimated to have been in the range of 50-70 k.y. These variations in the degree of soil-profile development indicate that the intervals between successive surface-faulting events could have varied from less than about 10 k.y. to perhaps as long as 75 k.y. (from about one-fourth to more than twice the average recurrence interval).

The elapsed time since the most recent event is not well constrained. It occurred after deposition of eolian/colluvial deposits (unit VIIIb) that were dated using thermoluminescence at $38 \pm 6 \mathrm{ka}$ and after a strongly developed soil formed on these deposits. Comparison of the soil formed on the colluvium deposited following the most recent event (unit IX) to soils on alluvial surface Qa5 in Midway Valley indicates that the most recent event is likely to have occurred during the latest Pleistocene or early Holocene.

\section{Midway Valley Fault}

The Midway Valley fault, named by Neal (1986), had been mapped by Lipman and McKay (1965) as a concealed fault extending north-northeast for more than $6 \mathrm{~km}$ through the central part of Midway Valley. A north-trending normal fault with down-to-the-west displacement in bedrock was mapped by Scott and Bonk (1984) in the southeastern part of Bow Ridge. This fault then was extended north beneath surficial deposits of Midway Valley as the Midway Valley fault by Day and others (1998), and connected with a bedrock fault north of Yucca Wash for a total length of more than $11 \mathrm{~km}$ (fig. 1). Along the lines of the geologic sections in figures 9A and 9B, estimated displacements in bedrock are shown to range from $30 \mathrm{~m}$ to about $100 \mathrm{~m}$, depending on the stratigraphic horizon involved.

Table 9. Estimated average recurrence interval for surface-fault ruptures on the Paintbrush Canyon fault at trench MWV-T4, on the basis of event stratigraphy.

[ka, thousand years before present; k.y./event, thousand years per event; --, not applicable; <, less than; $\leq$, less than or equal to]

\begin{tabular}{cccc}
\hline $\begin{array}{c}\text { Datum } \\
\text { (plate 5) }\end{array}$ & $\begin{array}{c}\text { Age } \\
\text { (ka) }\end{array}$ & Number of events & $\begin{array}{c}\text { Calculated recurrence } \\
\text { interval (k.y./event) }\end{array}$ \\
\hline VIIb & $38 \pm 6$ & 1 & -- \\
$\begin{array}{c}\text { VIIe } \\
\text { Unconformity at base } \\
\text { of unit VII }\end{array}$ & $73 \pm 9$ & 2 & $35 \pm 7$ \\
& $<130$ & 3 or 4 & $\leq 32$ to $\leq 43$ \\
& & $37 \pm 5$ \\
\hline
\end{tabular}


The results of geophysical surveys further support the presence of a north-trending fault underneath Midway Valley (pl. 3). Frischknecht and Raab (1984) obtained short-offset time-domain electromagnetic sounding data that indicate the central Midway Valley area contains "a major fault or fault zone ... which displaces the lower conductive layer about $400 \mathrm{~m}$ downward on the west side" (p. 987). On the basis of personal communications with other researchers, Frischknecht and Raab (1984) cited other evidence of the postulated Midway Valley fault, including a low-velocity zone at depth on a seismic refraction profile and a sharp, prominent gravity feature. They also suggest that there is weak, aeromagnetic evidence for faults at this location. Other resistivity/geoelectric surveys by Fitterman (1982), Senterfit and others (1982), and Smith and Ross (1982) revealed anomalies within Midway Valley that could be attributed to faulting; however, these anomalies are distributed widely across the valley. Seismic reflection and refraction surveys conducted in Midway Valley (Pankrantz, 1982; McGovern, 1983; Reynolds and Associates, 1985), on the other hand, have not succeeded in demonstrating conclusively the presence or absence of buried faults beneath Midway Valley. The seismic reflection survey by Reynolds and Associates (1985) yielded poor results, although they were able to identify three faults in central Midway Valley (pl. 3).

Ponce (1993) and Ponce and Langenheim (1994) conducted gravity and magnetic surveys and identified anomalies that were interpreted to be faults concealed by alluvial sediments in the central part of Midway Valley (fig. 11). These anomalies are much smaller than the anomalies produced by either the Paintbrush Canyon or Bow Ridge faults. Assuming a simple fault model and density contrasts, Ponce (1993) and Ponce and Langenheim (1994) fit a theoretical model to the gravity magnetic data that indicates tens of meters of vertical displacement of the bedrock stratigraphy across the Midway Valley fault.

No surface displacement has been observed and trenches were not excavated along the projected trace of the fault in Midway Valley. A fracture in soil pit MWV-P6 (see location in figure A1 in Appendix), however, coincides with a geophysical anomaly identified by Ponce (1993) and Ponce and Langenheim (1994). The fracture cuts Qa3 alluvial deposits, strikes N. $23^{\circ}$ E., and has a vertical dip. Bedding within Qa3 does not appear to be displaced across the fracture, and the overlying Qa4 alluvial deposits are not fractured. These observations are consistent with the relations observed in trenches across similar fractures observed in excavations at the prospective surface facilities site.

\section{Exile Hill Fault}

The Exile Hill fault is exposed in three trenches (MWV-T5, -T6, and -T7) along the east side of Exile Hill, as well as in the North Portal Duct Bank excavation located near borehole NRG-1 (pl. 1). The latter excavation is at the entrance of the north ramp of the Exploratory Studies Facility
(ESF). All of these excavations were mapped in detail; logs of trenches MWV-T5 and MWV-T7 (pls. 4 and 6) and a map of the North Portal excavation (pl. 8) are included in this report to illustrate the essential stratigraphic and structural relations that are exposed. The fault coincides with a down-to-the-east bedrock step in trench MWV-T5 (station $310 \mathrm{~m}, \mathrm{pl}$. 4B) and with a zone of silica-carbonate-filled fractures within Quaternary colluvial units exposed in soil pits along the eastern base of Exile Hill (pl. 9).

Electrical resistivity data (Senterfit and others, 1982; U.S. Geological Survey, 1984), seismic reflection and refraction data (Reynolds and Associates, 1985; Neal, 1986), and gravity and ground magnetic data (Ponce, 1993; Ponce and Langenheim, 1994) all indicate the presence of minor faulting along the eastern base of Exile Hill (pl. 3). The combined geologic and geophysical data were interpreted by Day and others (1998) to indicate that the subsurface trace of the northtrending Exile Hill fault merged with the Bow Ridge fault about $1.25 \mathrm{~km}$ north of Exile Hill and with the Midway Valley fault $2 \mathrm{~km}$ south of Exile Hill.

In trench MWV-T5, the Exile Hill fault separates moderately fractured and faulted units of the crystal-poor member of the Tiva Canyon Tuff at a depth of less than $1 \mathrm{~m}$ on the west from carbonate- and silica-laminated alluvium and colluvium continuing to a depth of more than $3 \mathrm{~m}$ on the east (north wall, pl. 4B). The main fault appears as a planar, northtrending subvertical to steeply east dipping silica-carbonatefilled fracture in bedrock that is continuous with similartrending silica-carbonate-filled fractures in the overlying Quaternary colluvial deposits. Minor structures developed within the laminated silica-carbonate along the fault plane within bedrock indicate a left-lateral component of shear on the main faults. The Exile Hill fault lies within a strongly brecciated zone about $1 \mathrm{~m}$ wide (313-314 m, pl. 4B) that is 30-50 percent matrix supported and contains prominent, extensional fractures that also are consistent with a left-lateral component of slip on the fault. An estimate of the vertical displacement across the fault at this exposure is not possible because bedrock was not exposed on the downthrown block. The fractures within the alluvium are continuous with the bedrock fault, but the soil and lithologic horizons are not displaced within the limits of resolution ( $5 \mathrm{~cm}$ or less). The bedrock step, therefore, also must represent an erosion-deposition contact that is superimposed on the original tectonic contact (that is, a paleo-fault-line scarp). This interpretation is supported by the presence of a wedgeshaped deposit of silica-carbonate laminae that fan outward from the top of the bedrock step into the alluvial deposits on the downthrown side of the bedrock step. The bedrock relief across the step is more than $3 \mathrm{~m}$ because the bedrock-alluvium contact on the downthrown (east) block was not exposed in the trench, but the relief is constrained to be less than $10 \mathrm{~m}$ by data from boreholes UE-25 RF-10 and RF-11.

Bedrock exposures of the Exile Hill fault also were observed in trench MWV-T7 (pl. 6) and in excavations for the North Portal Duct Bank (fig. 14, pl. 8). In trench MWV-T7, the fault lies entirely within the crystal-rich member of the 
Tiva Canyon Tuff. The greater-than-2-m step in the bedrock exposed in trench MWV-T5, however, was not observed in trench MWV-T7. The fault juxtaposes the middle part of the crystal-rich member on the west and the lower part of that unit on the east, indicating an apparent vertical displacement of less than $15 \mathrm{~m}$. In the North Portal Duct Bank exposure, the fault has an average strike of N. $21^{\circ} \mathrm{W}$., dips steeply to the east, and juxtaposes tuff " $\mathrm{X}$ " on the east against the uppermost part of the crystal-rich member of the Tiva Canyon Tuff on the west (fig. 14; pl. 8). On the basis of these relations, apparent vertical separation is less than $15-30 \mathrm{~m}$, depending on the stratigraphic position of tuff " $\mathrm{X}$ " in the hanging wall.

The bedrock faults identified in the excavations across the Exile Hill fault zone dip steeper than $70^{\circ}$, and the average dip is greater than $80^{\circ}$. Within the fault zone exposed in trench MWV-T7, variable crosscutting relations are common. For example, at one location a prominent N. $65^{\circ} \mathrm{W}$.-striking fault is offset by a fault striking N. $15^{\circ} \mathrm{E}$., yet $6 \mathrm{~m}$ to the east the $\mathrm{N}$. $65^{\circ} \mathrm{W}$--trending fault truncates a major fault zone that strikes N. $16^{\circ}$ E. At another location in trench MWV-T7, however, a N. $15^{\circ}$ E.-striking fault transects the floor and both walls of the trench, cutting all other trends. The N. $15^{\circ} \mathrm{E}$. group of bedrock faults is the only group of faults that is continuous with paral- lel fractures that extend into the overlying Quaternary colluvium (fig. 15).

In trench MWV-T5, the oldest colluvium (QTcu) does not appear to be faulted against bedrock, although fractures are present within this unit directly over the buried bedrock step (pl. 4B). Stratigraphic relations indicate that the colluvium was deposited across a bedrock step, and the upper part subsequently was eroded prior to deposition of younger unconformable units. The younger units have slopes similar to the modern slope, whereas the slope of QTcu is much steeper. This steeper slope is interpreted to result from draping across a bedrock fault-line scarp associated with the Exile Hill fault; however, a small amount of basinward tectonic tilting also is possible.

The contact between the carbonate-silica horizon of QTcu and the underlying bedrock has several steps of $10 \mathrm{~cm}$ or less across six or more bedrock shears between stations $24 \mathrm{~m}$ and $32 \mathrm{~m}$ in trench MWV-T7 (pl. 4). Down-to-the-west steps of the contact are most common, although the contact steps down-to-the-east across one fracture near station $30 \mathrm{~m}$. The bedrock shears strike roughly N. $10^{\circ}$ E., have near-vertical dips (east and west), and are continuous with carbonate-silicafilled fractures that extend into the Kq horizon of unit QTcu. The fractures either die out within QTcu or are truncated

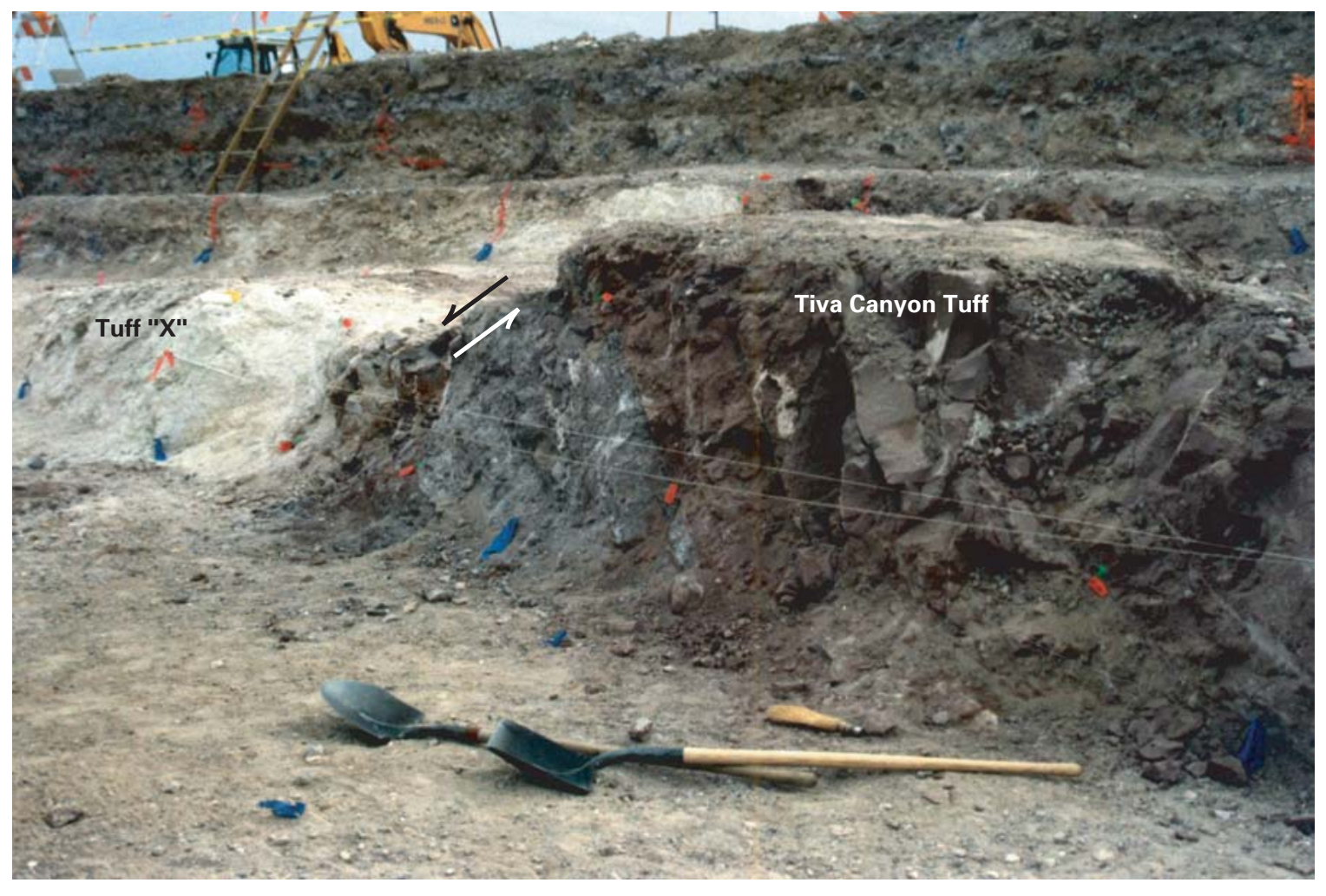

Figure 14. Exile Hill and East Portal faults exposed in south wall of North Portal Duct Bank excavation. Exile Hill fault displaces tuff " $X$ " (light-colored unit on left) down to the east against the crystal-rich member of the Tiva Canyon Tuff (fault is between arrows showing relative movement). View is to the south along trace of East Portal fault, which juxtaposes lower and upper units of the crystal-rich member. (Shovel approximately $1.5 \mathrm{~m}$ long.) 

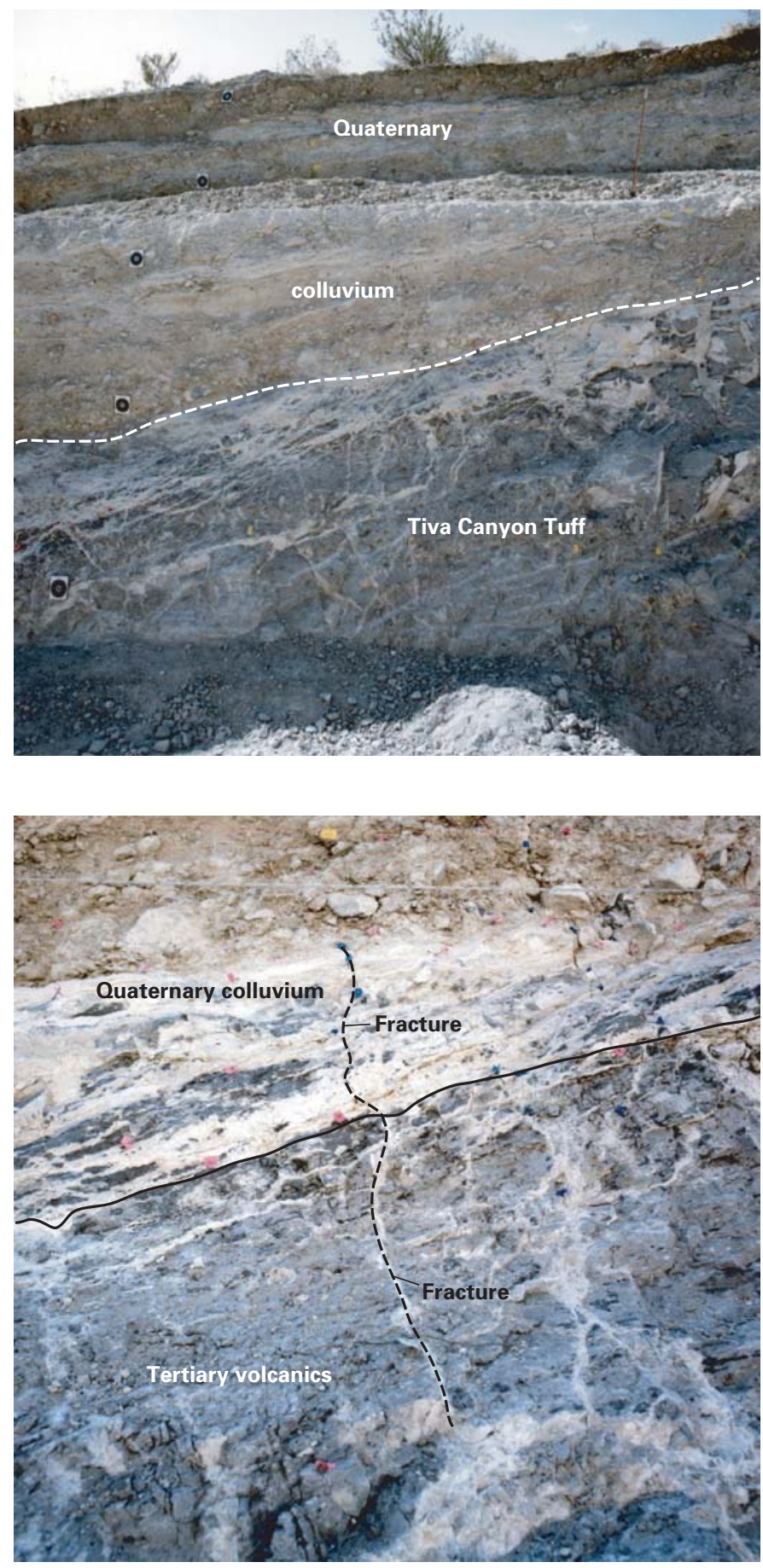

Figure 15. Top photograph, east-dipping contact between faulted Tiva Canyon Tuff (crystal-rich member) and the overlying early Pleistocene-Holocene colluvial deposits in south wall of trench MWV-T7 (east is to left). Bottom photograph, closeup of calcite-filled fracture (dashed line) extending upward from bedrock into colluvium, south wall of trench MWV-T7.

at the QTcu-Qc1(?) contact, which is not displaced across the fractures. The fractures do not extend into the overlying Quaternary colluvial sequence (Qc1? and younger).
Steeply dipping fractures that break, but do not displace, the Quaternary colluvial deposits and soils were observed in five of the trenches and soil pits that were excavated across the Exile Hill fault (pls. 4, 6, 9). The Quaternary fractures are coincident with a complex zone of bedrock faulting that contains a wide range of structural trends (fig. 15), but the Quaternary fractures are associated only with northeast-striking bedrock faults (pl. 6). These fractures define an approximately 15 -m-wide zone that strikes about N. $15^{\circ} \mathrm{E}$. and is parallel to and coincident with the bedrock trace of the Exile Hill fault. Individual fractures within the zone strike between N. $2^{\circ} \mathrm{E}$. and $\mathrm{N} .35^{\circ}$ E. and dip at a high angle.

No vertical separation of the probable middle Pleistocene colluvial units (Qc2 and Qc3) is apparent; in most cases, displacements on the order of a couple of centimeters or smaller can be precluded in these deposits. Likewise, no evidence of lateral offset of the colluvium, which also would have resulted in apparent vertical separations of units or abrupt changes in thickness of units across the fractures, was observed.

The relative differences in the width and character of the carbonate-silica seams within faults in bedrock and within fractures in colluvium may indicate multiple episodes of fracturing. Individual shears in bedrock contain much denser and thicker carbonate-silica seams than occur in the fractures that cut the overlying colluvium. Seams within some bedrock faults attain widths of 50-100 mm. In most cases the maximum width of carbonate-silica seams within fractures in colluvium is less than $10 \mathrm{~mm}$. Close inspection of the carbonate-silica seams filling fractures in both bedrock and colluvium reveal multiple laminae that are parallel to the fracture walls, indicating multiple episodes of infilling.

The most recent fracturing event appears to predate deposition of Qc4, because this unit is not fractured (pl. 4), and to postdate deposition of colluvial units Qc2 and Qc3, which are fractured. Some fractures die out upward within Qc3, and others are abruptly truncated at the Qc3-Qc4 contact. Unit Qc4 is absent above the fractures in MWV-T7 (pl. 6), NRSF-TP7 (pl. 9), and NRSF-TP32 (pl. 9). Fractures within NRSF-TP32 die out upward in the Bkq horizon of the soil developed in uppermost Qc3, fractures within NRSF-TP7 are abruptly truncated at the Qc3-Qc5 contact, and fractures showing both these relations occur in MWV-T7. For example, a fracture that breaks Qc3 and abruptly ends at the Qc3-Qc5 contact within trench MWV-T7 is shown in figure 16.

\section{Other Inferred Faults at the Prospective Surface Facilities Site}

Bedrock mapping and borehole and geophysical data have been interpreted to indicate that two or more faults with small bedrock offsets lie buried beneath surficial deposits between the traces of the Exile Hill and Midway Valley faults (figs. 9A, 9B, 9C). Although the exact number of such faults is indeterminable because bedrock is not exposed east of station $313 \mathrm{~m}$ in trench MWV-T5 (pl. 4B), their presence is indicated 


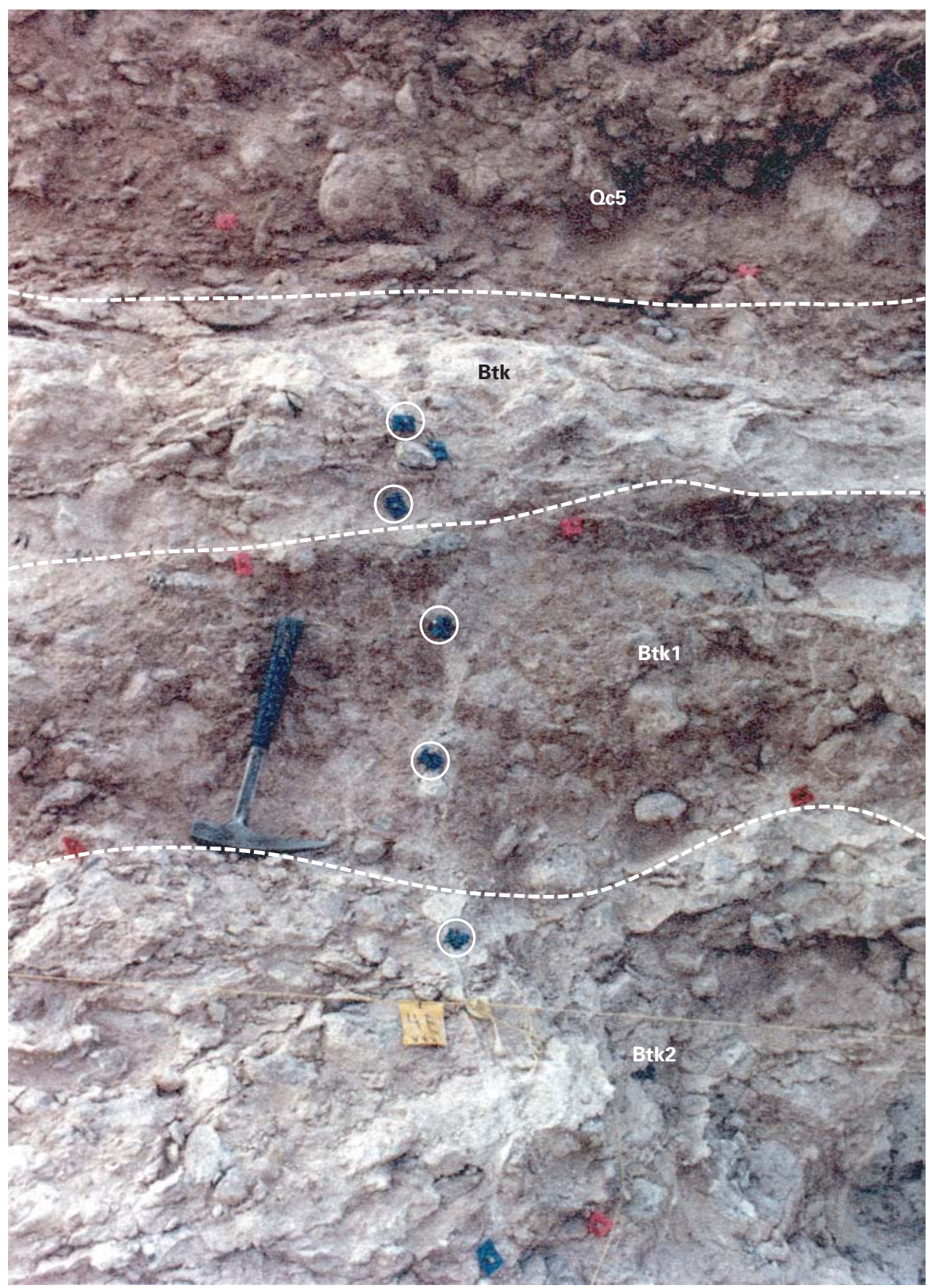

Figure 16. Carbonate-filled fracture (marked by circled tags) in Btk and Bkq soil horizons on 0c3 colluvium exposed in south wall of trench MWV-T7. Fracture does not extend into overlying 0c5 deposits. Dashed lines are contacts between soil horizons. (Hammer for scale.)

by stratigraphic mismatches between (1) bedrock exposures on Exile Hill and borehole UE-25 RF-11; (2) boreholes UE-25 RF-11 and RF-9; and (3) boreholes UE-25 RF-9 and UE-25 RF-3 (fig. 9C). The orientation and amount and sense of displacement of these faults are not well constrained, but they are inferred to be north- to northeast-trending normal faults, based on the known fault pattern in the area. The generalized geologic section in figure 9C, prepared principally from bore- hole data, shows three faults between the Exile Hill fault and the location of borehole UE-25 RF-3 to the east. Two of the faults appear to dip steeply to the west, with down-to-thewest bedrock displacements of $20-25 \mathrm{~m}$, and the third fault is interpreted to dip to the east with a down-to-the-east bedrock displacement of about $17 \mathrm{~m}$ (fig. 9C). Day and others (1998) show two concealed north-trending normal faults between the Exile Hill and Midway Valley fault, one with down-to-the-west 
displacement and the other with down-to-the-east displacement.

Fractures are present in Quaternary alluvium in the eastern $135 \mathrm{~m}$ of trench MWV-T5 (pls. 2 and 4A), forming a zone with individual fractures striking between N. $3^{\circ}-53^{\circ} \mathrm{E}$. (general strike, N. $12^{\circ}-37^{\circ}$ E.). All dip at a high angle, and all but two were observed on both trench walls. The association of this zone of fractures with bedrock faults is uncertain, as no bedrock is exposed in this section of the trench where the alluvium-bedrock contact is $30 \mathrm{~m}$ deep as indicated by borehole data (fig. 9C). However, there are sources of independent data indicating that a bedrock fault is present in this area, including (1) irregular high-angle fractures and small bedrock faults observed in the core of borehole UE-25 RF-3; (2) a north-trending, down-to-the-east fault inferred by Neal (1986) and Reynolds and Associates (1985) on the basis of seismic reflection data (pls. 2 and 3); and (3) a relatively smalldisplacement, down-to-the-east fault as inferred from gravity and ground magnetic signatures that are similar to the Exile Hill fault (Ponce, 1993; Ponce and Langenheim, 1994) (fig. 11; pl. 3).

No apparent vertical separation of the Quaternary alluvial deposits could be detected for any individual fracture within the zone (fig. 17; pl. 4A), nor was any evidence of lateral offset observed. Resolution of the amount of offset primarily depends upon the distinctness of contacts separating stratigraphic units, bedding within stratigraphic units, and soil horizon boundaries (table 10). The following limits of resolution are generally applicable: Qa2-Qa3 contact to within $1 \mathrm{~cm}$, bedding in Qa2 to within $5 \mathrm{~cm}$, and bedding in Qa3 to within $5-10 \mathrm{~cm}$.

At least two fracturing events are indicated by the truncation of some fractures at the Qa2-Qa3 contact (fig. 17B), whereas other fractures break this contact and continue into the overlying Qa3 (fig. 17B; pl. 4A). For example, one fracture that breaks through both Qa2 and Qa3 near station $17 \mathrm{~m}$ is located $2 \mathrm{~m}$ away from a fracture that is abruptly truncated at the Qa2-Qa3 contact; a similar relation also is observed near station $36 \mathrm{~m}$ and $65 \mathrm{~m}$. The fracturing in the eastern end of MWV-T5 occurred prior to deposition of Qc4. Fractures extending into Qa3 generally die out within the Bk or $\mathrm{K}$ horizon of the soil formed in Qa3 and do not penetrate Qa4.

\section{Origin of Fractures in Quaternary Deposits}

As discussed earlier (1) a western zone of fractures that was mapped in colluvial deposits along the east side of Exile Hill are associated with the northeast-trending Exile Hill fault; and (2) an eastern zone of fractures occurs in alluvial sediments toward the eastern end of trench MWV-T5 (pls. 2 and 4) and may be associated with an inferred north-trending bedrock fault beneath the surficial cover. No displacement of lithologic contacts and soil horizons could be detected in the fractured Quaternary deposits, and, in most cases, displacements can be precluded with a high degree of confidence. The orientation of the fractures (north-northeast trend, table 10) is consistent with a least horizontal principal stress axis of N. $60^{\circ}-65^{\circ} \mathrm{W}$. that is indicated by hydraulic fracturing stress measurements and core break-out data (Stock and Healy, 1988).

The origin of the fractures is uncertain. Non-tectonic mechanisms cannot be completely ruled out, but they appear less likely given the consistent orientation of the fractures, the continuity of the fractures along strike, the coincidence of the western zone of Quaternary fractures with the Exile Hill fault, and the fact that individual fractures in the colluvial deposits are continuous with faults in the underlying Tertiary bedrock. The most plausible non-tectonic mechanisms include (1) fractures resulting from the growth of secondary minerals in bedrock shears and fractures; (2) fractures produced by an ephemeral disruption during the transmission of seismic waves (for example, strong ground shaking from earthquake on nearby fault); or (3) release of residual stress in the Tertiary bedrock. However, the first two mechanisms do not explain why, despite the existence of faults and fractures having a wide variety of trends along the zone of faulting at the base of Exile Hill, Quaternary fractures are associated only with the northto northeast-trending faults. The episodic, although infrequent, development of tension fractures during the early and middle Quaternary is difficult to explain simply by release of residual stress. Partial release of residual stress in shallow rock during successive, widely separated, episodes on a preexisting bedrock fault seems unlikely without an external triggering mechanism.

Paleoseismic data indicate that there have been repeated middle to late Quaternary surface-fault ruptures on the Bow Ridge fault to the west and Paintbrush Canyon fault to the east. Given the episodic occurrence of the fractures and their consistent north-northeast orientation, it seems likely that the Quaternary fractures represent either minor intrablock deformation within the relatively stable Midway Valley structural block, or they resulted from sympathetic ground motion from nearby earthquakes.

\section{Northwest-Trending Faults}

Two northwest-trending dip-slip to oblique-slip faults with small displacements were identified during detailed bedrock mapping of Exile Hill (pls. 1 and 2; fig. 9C). These features, informally referred to as the East Portal fault and the West Portal fault, project southeast toward a possible intersection with the Reference Conceptual Site and the prospective surface facilities site (fig. 2); detailed descriptions are given below. Three other northwest-trending faults-Drill Hole Wash, Pagany Wash, and Sever Wash faults-with mainly strike-slip displacements occur in prominent washes to the west and project toward the west side of Midway Valley (fig. 1). As discussed in an earlier section, these faults appear to terminate against the north-trending western strand of the Bow Ridge fault west of Exile Hill; therefore, these faults are not considered to be features that affected the geologic 

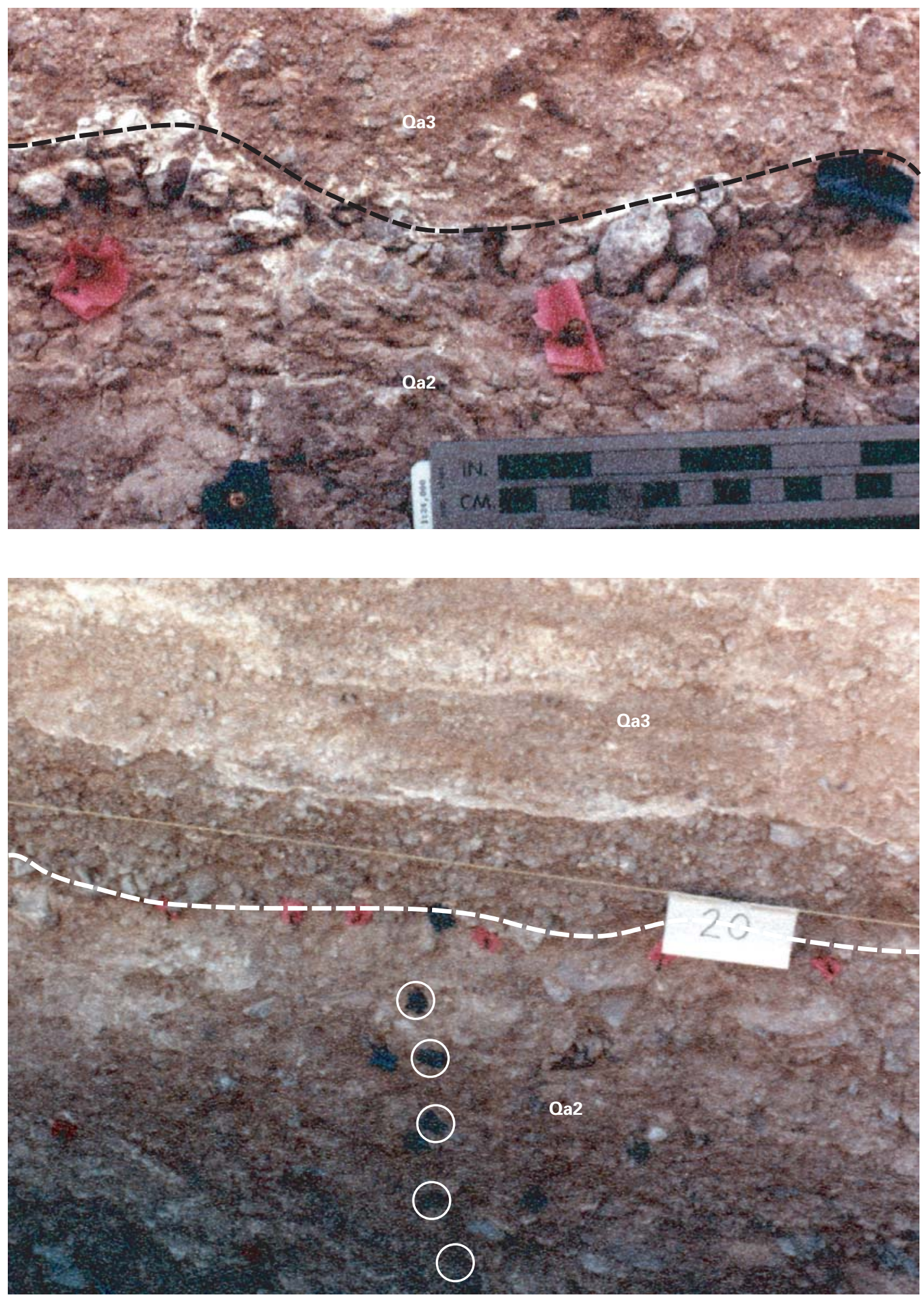

Figure 17. Calcite-filled fractures associated with the eastern zone of fractures exposed in trench MWV-T5 (south wall): $A$, fracture in $0 \mathrm{a} 2$ and $\mathrm{Qa} 3$ deposits; there is no measurable displacement of the contact between these units, which is marked by a 1- to 2-cm-thick pebble layer at the base of $0 \mathrm{a} 3$. B, fracture (marked by circled tags) in $0 \mathrm{a} 2$ deposits; fracture does not extend into the overlying $\mathrm{Oa}_{3}$ deposits. The vertical exposure shown is about $2.2 \mathrm{~m}$. 
Table 10. Characteristics of fractures exposed in the eastern fracture zone of trench MWV-T5, Midway Valley.

[m, meters; cm, centimeters; -- no information; >, greater than; $\leq$, less than or equal to ]

\begin{tabular}{|c|c|c|c|c|c|}
\hline $\begin{array}{l}\text { Station }(\mathrm{m}) \\
\text { (see plate 4A) }\end{array}$ & Strike $^{1}$ & Lateral continuity $^{2}$ & Fractured stratigraphic unit(s) & Unfractured stratigraphic unit(s) & Resolution $^{3}$ \\
\hline 18 & N. $18^{\circ}$ E. & Yes & Qa2, Qa3 & $\begin{array}{l}\text { Qa4+Qe4, Bkq-Kq horizon of Soil S3. } \\
\text { Fracture dies out in Soil S3. }\end{array}$ & $\begin{array}{l}\text { Qa2/Qa3 contact: } \pm 0.5 \mathrm{~cm} \\
\text { Bedding in Qa2: } \pm 0.5 \mathrm{~cm} \\
\text { Soil S2 in Qa2: } \pm 10 \mathrm{~cm} \\
\text { Bedding in Qa3: } \pm 0.25 \mathrm{~cm} \\
\text { Soil S3 in Qa3: }--\end{array}$ \\
\hline 20 & N. $16^{\circ} \mathrm{E}$. & Yes & Qa2 & $\begin{array}{l}\text { Qa3, Qa4 } \\
\text { Fracture truncated at the Qa2-Qa3 contact. }\end{array}$ & $\begin{array}{l}\text { Qa2/Qa3 contact: } \pm 1 \mathrm{~cm} \\
\text { Bedding in Qa2: } \pm 5 \mathrm{~cm} \\
\text { Soil S2 in Qa2: } \pm 10 \mathrm{~cm} \\
\text { Bedding in Qa3: -- } \\
\text { Soil S3 in Qa3: -- }\end{array}$ \\
\hline 29.5 & N. $12^{\circ}$ E. & Yes & Qa2, Qa3 & $\begin{array}{l}\text { Qa4+Qe4, Kq horizon of Soil S3. } \\
\text { Fracture dies out in Soil S3. }\end{array}$ & $\begin{array}{l}\text { Qa2/Qa3 contact: } \bullet 12 \mathrm{~cm} \\
\text { Bedding in Qa2: } \pm 5 \mathrm{~cm} \\
\text { Soil S2 in Qa2: } \pm 2 \mathrm{~cm} \\
\text { Bedding in Qa3: } \pm 0.5 \mathrm{~cm} \\
\text { Soil S3 in Qa3: -- }\end{array}$ \\
\hline 36.5 & N. $12^{\circ}$ E. & Yes & $\begin{array}{l}\text { Eastern fracture: Qa2, Qa3 } \\
\text { Western fracture: Qa2 }\end{array}$ & $\begin{array}{l}\text { Eastern fracture: Qa4+Qe4, Bkq-Kq horizon of } \\
\text { Soil S3. } \\
\text { Fracture dies out in Soil S3 } \\
\text { Western fracture: Qa3, Qa4-Qe4; Fracture dies out } \\
\text { in Soil S2. }\end{array}$ & $\begin{array}{l}\text { Qa2/Qa3 contact: } \pm 2.5 \mathrm{~cm} \\
\text { Bedding in Qa2: } \pm 0.5 \mathrm{~cm} \\
\text { Soil S2 in Qa2: -- } \\
\text { Bedding in Qa3: -- } \\
\text { Soil S3 in Qa3: } \pm 5 \mathrm{~cm}\end{array}$ \\
\hline 64.5 & N. $30^{\circ} \mathrm{E}$. & Yes & $\begin{array}{l}\text { Eastern fracture: Qa2 } \\
\text { Western fracture: Qa2, Qa3 }\end{array}$ & $\begin{array}{l}\text { Eastern fracture: Qe4, Qa3 } \\
\text { Fracture truncated at Qa2-Qa3 contact. } \\
\text { Western fracture: Qe4 } \\
\text { Fracture dies out in Soil S3. }\end{array}$ & $\begin{array}{l}\text { Qa2/Qa3 contact: } \pm 0.5 \mathrm{~cm} \\
\text { Bedding in Qa2: } \pm 5 \mathrm{~cm} \\
\text { Soil S2 in Qa2: } \pm 1 \mathrm{~cm} \\
\text { Bedding in Qa3: } \pm 3 \mathrm{~cm} \\
\text { Soil S3 in Qa3: } \pm 2.5-5.5 \mathrm{~cm}\end{array}$ \\
\hline 84 & N. $3^{\circ} \mathrm{E}$. & Yes & $\begin{array}{l}\text { Qa2, Qa3 } \\
\text { Rotated clasts along indistinct fracture. }\end{array}$ & $\begin{array}{l}\text { Bkq horizon of Soil S3, Qa5 } \\
\text { Fracture dies out in Soil S3. }\end{array}$ & $\begin{array}{l}\text { Qa2/Qa3 contact: } \pm 2 \mathrm{~cm} \\
\text { Bedding in Qa2: } \pm 2.5-5.5 \mathrm{~cm} \\
\text { Soil S2 in Qa2: -- } \\
\text { Bedding in Qa3: -- } \\
\text { Soil } \mathrm{S} 3 \text { in Qa3: }> \pm 5.5 \mathrm{~cm}\end{array}$ \\
\hline 86.5 & N. $37^{\circ}$ E. & Yes & $\begin{array}{l}\text { Qa2, Qa3 } \\
\text { Three parallel fractures }\end{array}$ & $\begin{array}{l}\text { Qa4 } \\
\text { Fractures die out within Qa3. }\end{array}$ & $\begin{array}{l}\text { Qa2/Qa3 contact: } \pm 5 \mathrm{~cm} \\
\text { Bedding in Qa2: } \pm 2.5-5.5 \mathrm{~cm} \\
\text { Soil S2 in Qa2: }-- \\
\text { Bedding in Qa3: -- } \\
\text { Soil S3 in Qa3: } \pm 2.5-5.5 \mathrm{~cm}\end{array}$ \\
\hline 97.5 & N/A & No & $\begin{array}{l}\text { Qa3 } \\
\text { Fracture is indistinct and not present on north wall. }\end{array}$ & $\begin{array}{l}\text { Soil S3, Qa5 } \\
\text { No fracturing observed in underlying Qa2. }\end{array}$ & $\begin{array}{l}\text { Qa2/Qa3 contact: } \pm 2.5 \mathrm{~cm} \\
\text { Bedding in Qa2: -- } \\
\text { Soil S2 in Qa2: -- } \\
\text { Bedding in Qa3: -- } \\
\text { Soil S3 in Q3: -- }\end{array}$ \\
\hline
\end{tabular}




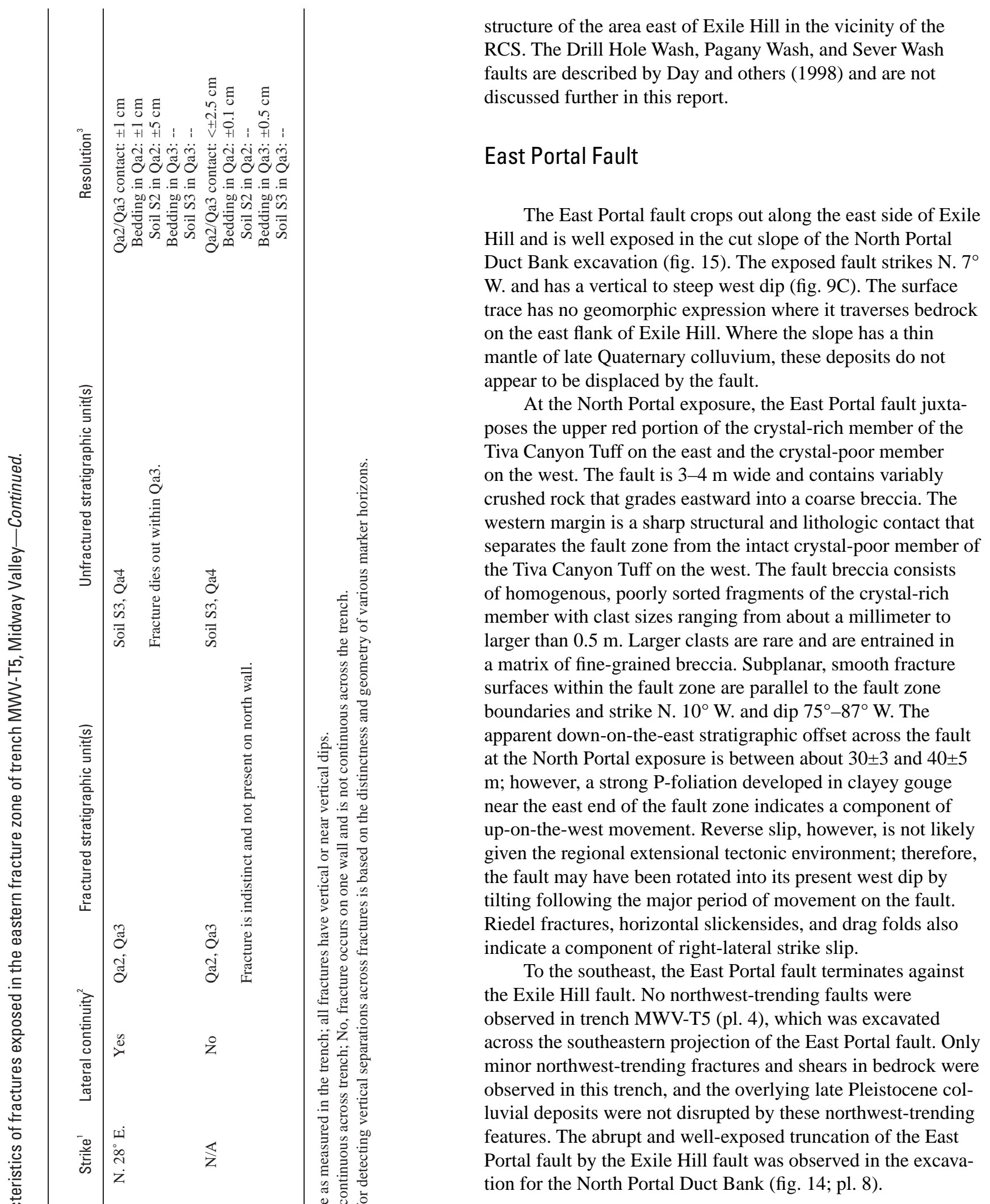

West Portal Fault

The West Portal fault was mapped initially on the basis of a change in bedrock lithology coincident with a zone of 
brecciation (S.C. Beason, U.S. Bureau of Reclamation, oral commun., 1994). The fault strikes about N. $20^{\circ} \mathrm{W}$. and dips $88^{\circ}$ NE. (pls. 1 and 2; figure 9C). The West Portal fault has no geomorphic expression where it traverses bedrock on the east flank of Exile Hill, and Quaternary colluvium, where present, does not appear to be displaced by the fault. In bedrock outcrops, the West Portal fault consists of a minor breccia zone less than $1 \mathrm{~m}$ wide that juxtaposes upper units of the crystalrich member of the Tiva Canyon Tuff on the east and lower units of that member as well as units within the underlying crystal-poor member on the west (pl. 1).

The West Portal fault was exposed in the cut for the NRG-1 access road, where it appeared as a narrow (less than $5 \mathrm{~cm}$ wide) gouge- and calcite-filled fracture that strikes $\mathrm{N}$. $22^{\circ}$ W., dips $86^{\circ} \mathrm{NE}$., and places the crystal-rich member of the Tiva Canyon Tuff on the east against the crystal-poor member on the west (pl. 1). Fibrous calcite lineations, plunging $76^{\circ}$ toward N. $3^{\circ}$ E., and growths of massive silica on the underside of downdip steps that developed on the footwall fault surface both indicate down-to-the-east normal movement with a minor left-lateral component. Assuming a thickness of $22.1 \mathrm{~m}$ for the units of the crystal-rich member of the Tiva Canyon Tuff as measured in borehole NRG-2a, the vertical separation across the fault where it crosses the NRG-1 access road on the east slope of Exile Hill is estimated to be less than $15 \mathrm{~m}$. The total fault displacement, based on the observed outcrop geometry, is calculated to be about $10 \pm 2 \mathrm{~m}$ at this locality.

Based on contact relations and changes in lithology, the West Portal fault is mapped as far northwest as $200 \mathrm{~m}$ beyond the northern peak of Exile Hill, where the crystal-rich member of the Tiva Canyon Tuff also may be vertically offset about 10 $\mathrm{m}$. The fault terminates to the southeast against the Exile Hill fault. As noted previously, no zone of northwest-trending faults was observed in trench MWV-T5 (pl. 4), and the overlying late Pleistocene colluvial sequence was not disrupted.

\section{Summary and Conclusions}

A detailed study of the geology of Midway Valley, with principal emphasis on the stratigraphy and structure of Quaternary surficial deposits, was undertaken in cooperation with the U.S. Department of Energy to determine whether future faulting poses a hazard to prospective surface facilities associated with the potential high-level radioactive waste repository at Yucca Mountain, Nevada.

The dominant tectonic features in Midway Valley are the north-trending, west-dipping normal faults along the valley margins-Bow Ridge fault to the west and Paintbrush Canyon fault to the east - that displace Tertiary volcanic rocks as much as $500 \mathrm{~m}$. Both of these faults also show evidence of multiple faulting events during middle to late Quaternary time, with displacements per event ranging from less than $10 \mathrm{~cm}$ to nearly $1 \mathrm{~m}$. The site for the prospective surface facilities is on the footwall block of the Bow Ridge fault, about $150 \mathrm{~m}$ east of the main fault trace. However, the results of the geologic mapping and trench investigations discussed in this report indicate the absence of any measurable Quaternary faulting activity in the vicinity of the site, at least since the deposition of middle Pleistocene deposits estimated to be between 350 and $76 \mathrm{ka}$. Because none of the Quaternary faulting events recorded for the Bow Ridge fault (most recent event 80-70 ka) produced any observable secondary faulting, the potential for such faulting to occur at the prospective surface facilities site as a result of future displacements on the Bow Ridge fault is considered to be negligible. It seems reasonable to apply the same conclusion regarding the possible effects of future activity on the Paintbrush Canyon fault, as well as to ruptures along the Midway Valley fault or other faults in Midway Valley.

\section{References Cited}

Abdou, F.M., Hanna, F.S., Rabei, F.H., El Araby, A.M., and Rahman, S.L.A., 1984, Formation of calcium carbonate in some calcareous soils: Egyptian Journal of Soil Science, v. 24, p. 145-152.

Aguirre, E., and Pasini, G., 1984, The Pliocene-Pleistocene boundary: Episodes, v. 8, no. 2, International Union of Geological Sciences, Herndon, Virginia, p. 116-120.

Bath, G.D., and Jahren, C.E., 1985, Investigation of an aeromagnetic anomaly on west side of Yucca Mountain, Nye County, Nevada: U.S. Geological Survey Open-File Report 85-459, 24 p.

Birkeland, P.W., 1984, Soils and geomorphology: New York, Oxford University Press, $372 \mathrm{p}$.

Birkeland, P.W., Machette, M.N., and Haller, K.M., 1991, Soils as a tool for applied Quaternary geology: Utah Geological and Mineral Survey Miscellaneous Publication 91-3, 63 p.

Buesch, D.C., Dickerson, R.P., Drake, R.M., and Spengler, R.W., 1994, Integrated geology and preliminary cross section along the north ramp of the Exploratory Studies Facility, Yucca Mountain, in High Level Radioactive Waste Management: Proceedings of the Fifth Annual International Conference, Las Vegas, Nevada, May 1994, La Grange Park, Illinois, American Nuclear Society and American Society of Civil Engineers, v. 2, p. 1055-1065.

Buesch, D.C., Spengler, R.W., Moyer, T.C., and Geslin, J.K., 1996, Proposed stratigraphic nomenclature and macroscopic identification of lithostratigraphic units of the Paintbrush Group exposed at Yucca Mountain, Nevada: U.S. Geological Survey OpenFile Report 94-469, $47 \mathrm{p}$.

Bull, W.B., 1991, Geomorphic responses to climate change: New York, Oxford University Press, $326 \mathrm{p}$.

Byers, F.M., Jr., Carr, W.J., Orkild, P.P., Quinlivan, W.D., and Sargent, K.A., 1976, Volcanic suites and related cauldrons of Timber Mountain-Oasis Valley caldera complex, southern Nevada: U.S. Geological Survey Professional Paper 919, 70 p.

Carr, W.J., 1984, Regional structural setting of Yucca Mountain, southwestern Nevada, and late Cenozoic rates of tectonic activity 
in part of the southwestern Great Basin, Nevada and California: U.S. Geological Survey Open-File Report 84-854, 109 p.

Carr, W.J., 1992, Structural model for western Midway Valley based on RF drillhole data and bedrock outcrop, Appendix A, in Gibson, J.D., Swan, F.H., Wesling, J.R., Bullard, T.F., Perman, R.C., Angell, M.M., and DiSilvestro, L.A., Summary and Evaluation of Existing Geological and Geophysical Data Near Prospective Surface Facilities in Midway Valley, Yucca Mountain Project: Sandia National Laboratories, Sandia Report SAND90-2491, 4 plates, 6 appendixes, $94 \mathrm{p}$.

Dan, J., 1983, Soil chronosequences in Israel: Catena, v. 10, p. 287-319.

Day, W.C., Dickerson, R.P., Potter, C.J., Sweetkind, D.S., San Juan, C.A., Drake, R.M., III, and Fridrich, C.J., 1998, Bedrock geologic map of the Yucca Mountain area, Nye County, Nevada: U.S. Geological Survey Geologic Investigations Series I-2627, 1 sheet, scale 1:24,000; pamphlet text, $21 \mathrm{p}$.

Davis, J., 1983, Geological reconnaissance and chronologic studies: Reno, Nevada, Desert Research Institute Technical Report No. 33, $15 \mathrm{p}$.

Dickerson, R.P., and Drake, R.M., III, 1998, Geologic map of the Paintbrush Canyon area, Yucca Mountain, Nevada: U.S. Geological Survey Open-File Report 97-783, 25 p., scale 1:6,000.

Dickerson, R.P., and Spengler, R.W., 1994, Structural character of the northern segment of the Paintbrush Canyon fault, Yucca Mountain, Nevada, in High Level Radioactive Waste Management: Proceedings of the Fifth Annual International Conference, Las Vegas, Nevada, April 1994, La Grange Park, Illinois, American Nuclear Society and American Society of Civil Engineers, v. 4, p. 2367-2372.

Dietrich, R.V., Dutro, J.T., Jr., and Foose, R.M., 1982, AGI data sheets for geology in the field, laboratory, and office: American Geological Institute.

Dohrenwend, J.C., Bull, W.B., McFadden, L.D., Smith, G.I., Smith, R.S.U., and Wells, S.G., 1991, Quaternary geology of the Basin and Range Province in California, in Morrison, R.B., ed., Quaternary nonglacial geology, conterminous United States: Geological Society of America, Geology of North America, v. K-2, p. 321-352.

Fitterman, D.V., 1982, Magnetometric resistivity survey near Fortymile Wash, Nevada Test Site, Nevada: U.S. Geological Survey Open-File Report 82-401, 27 p.

Flanigan, V.J., 1981, A slingram survey at Yucca Mountain on the Nevada Test Site: U.S. Geological Survey Open-File Report 81-980, $38 \mathrm{p}$.

Frischknecht, F.C., and Raab, P.V., 1984, Time-domain electromagnetic soundings at the Nevada Test Site, Nevada: Geophysics, v. 49, no. 7, p. 981-992.

Frizzell, V.A., Jr., and Shulters, Jacqueline, 1990, Geologic map of the Nevada Test Site, Nevada: U.S. Geological Survey Miscellaneous Investigations Map I-2046, scale 1:100,000.

Geslin, J.K., and Moyer, T.C., 1995, Summary of lithologic logging of new and existing boreholes at Yucca Mountain, Nevada, March 1994 to June 1994: U.S. Geological Survey Open-File Report 94-451, $16 \mathrm{p}$.
Geslin, J.K., Moyer, T.C., and Buesch, D.C., 1995, Summary of lithologic logging of new and existing boreholes at Yucca Mountain, Nevada, August 1993 to February 1994: U.S. Geological Survey Open-File Report 94-342, $39 \mathrm{p}$.

Gibson, J.D., Shephard, L.E., Swan, F.H., Wesling, J.R., and Kerl, F.A., 1990, Synthesis of studies for the potential of fault rupture at the proposed surface facilities, Yucca Mountain, Nevada, in High Level Radioactive Waste Management: Proceedings of the First Annual International Conference, Las Vegas, Nevada, April 1990, La Grange Park, Illinois, American Nuclear Society and American Society of Civil Engineers, v. 1, p. 109-116.

Gibson, J.D., Swan, F.H., Wesling, J.R., Bullard, T.F., Perman, R.C., Angell, M.M., and DiSilvestro, L.A., 1992, Summary and evaluation of existing geological and geophysical data near prospective surface facilities in Midway Valley, Yucca Mountain project, Nye County, Nevada: Sandia National Laboratories Report SAND90-2491, 4 plates, 6 appendixes, 94 p.

Gile, L.H., Peterson, F.F., and Grossman, R.B., 1966, Morphological and genetic sequences of carbonate accumulation in desert soils: Soil Science, v. 101, no. 5, p. 347-360.

Harden, J.W., Slate, J.L., Lamothe, P., Chadwick, O., Pendall, E., and Gillespie, A., 1991, Soil formation on the Trail Canyon alluvial fan, Fish Lake Valley, Nevada: U.S. Geological Survey Open-File Report 91-291, 22 p.

Harden, J.W., Taylor, E.M., Hill, C., Mark, R.K., McFadden, L.D., Reheis, M.C., Sowers, J.M., and Wells, S.G., 1991, Rates of soil development from four soil chronosequences in the southern Great Basin: Quaternary Research, v. 35, p. 383-399.

Harden, J.W., Taylor, E.M., Reheis, M.C., and McFadden, L.D., 1991, Calcic, gypsic, and siliceous soil chronosequences in arid and semiarid environments, in Nettleton, W.D., ed., Occurrence, Characteristics, and Genesis of Carbonate, Gypsum, and Silica Accumulations in Soils: Soil Science Society of America Special Publication No. 26, p. 1-16.

Harrison, J.B.J., McFadden, L.D., and Weldon, R.J. III, 1990, Spatial soil variability in the Cajon Pass chronosequence: Implications for the use of soils as a geochronological tool: Geomorphology, v. 3, p. 399-416.

Harrison, J.B.J., McFadden, L.D., Weldon, R.J., and Kendrick, K.J., 1994, Spatial variability of soils on terrace treads in Cajon Pass, in McGill, S.F., and Ross, T.M., eds., Geological Investigations of an Active Margin: Geological Society of America Cordilleran Section Guidebook, Redlands, California, San Bernardino County Museum Association, p. 156-160.

Heizler, M.T., Perry, F.V., Crowe, B.M., Peters, L., and Appelt, R., 1999, The age of the Lathrop Wells volcanic center: $\mathrm{An}{ }^{40} \mathrm{Ar} /{ }^{39} \mathrm{Ar}$ dating investigation: Journal of Geophysical Research, v. 104, no. B1, p. 767-804.

Hoover, D.L., 1989, Preliminary description of Quaternary and late Pliocene surficial deposits at Yucca Mountain and vicinity, Nye County, Nevada: U.S. Geological Survey Open-File Report 89-359, $45 \mathrm{p}$.

Hoover, D.L., Chornack, M.P., and Broker, M.M., 1982, E-field ratio telluric traverses near Fortymile Wash, Nevada Test Site, Nevada: U.S. Geological Survey Open-File Report 82-1042, 14 p. 
Hoover, D.L., and Morrison, J.N., 1980, Geology of the Syncline Ridge area related to nuclear waste disposal, Nevada Test Site, Nye County, Nevada: U.S. Geological Survey Open-File Report 80-942, $70 \mathrm{p}$.

Hoover, D.L., Swadley, W C, and Gordon, A.J., 1981, Correlation characteristics of surficial deposits with a description of surficial stratigraphy in the Nevada Test Site region: U.S. Geological Survey Open-File Report 81-512, 27 p.

Hopkins, D.M., 1975, Time-stratigraphic nomenclature for the Holocene epoch: Geoderma, v. 14, no. 1, p. 2.

Imbrie, J., Hays, J.D., Martinson, D.G., McIntyre, A., Mix, A.C., Morley, J.J., Pisias, N.G., Prell, W.L., Shackleton, N.J., 1984, The orbital theory of Pleistocene climate: Support from a revised chronology of the Marine 0 record, in Berber and others, eds., Milankovitch and Climate, Part I: Netherlands, Reidel Publishing Company, $\mathrm{p}$. 269-305.

Jenny, H., 1941, Factors of soil formation: New York, McGraw-Hill, $281 \mathrm{p}$.

Lipman, P.W., and McKay, E.J., 1965, Geologic map of the Topopah Spring SW quadrangle, Nye County, Nevada: U.S. Geological Survey Geologic Quadrangle Map GQ-439, scale 1:24,000.

Machette, M.N., 1985, Calcic soils of the southwestern United States, in Weide, D.L., ed., Soils and Quaternary Geomorphology of the Southwestern United States: Geological Society of America Special Paper 216, p. 1-21.

McDonald, E., McFadden, L.D., and Wells, S.G., 1992, The influence of dust and lithology on the coevolution of desert pavements and vesicular A horizons on alluvial fans: Geological Society of America Abstracts with Programs, v. 24, no. 5, p. A355.

McDonald, E., and McFadden, L.D., 1994, Quaternary stratigraphy of the Providence Mountain piedmont and preliminary age estimates and regional stratigraphic correlations of Quaternary deposits in the eastern Mojave Desert, California, in McGill, S.F., and Ross, T.M., eds., Geologic Investigations of an Active Margin: Geological Society of America Cordilleran Section Guidebook, Redlands, California, San Bernardino County Museum Association, p. 205-210.

McFadden, L.D., 1982, The impacts of temporal and spatial climatic changes on alluvial soils genesis in southern California: Tucson, University of Arizona, Ph.D. dissertation, 430 p.

McFadden, L.D., 1988, Climatic influences on rates and processes of soil development in Quaternary deposits of southern California, in Reinhardt, J., and Sigleo, W.R., eds., Paleosols and Weathering through Geologic Time-Principles and Applications: Geological Society of America Special Paper 206, p. 153-177.

McFadden, L.D., and Weldon, R.J., 1987, Rates and processes of soil development in Quaternary terraces in Cajon Pass, southern California: Geological Society of America Bulletin, v. 98, p. 280-293.

McFadden, L.D., Wells, S.G., and Jercinovich, M.J., 1987, Influences of eolian and pedogenic processes on the origin and evolution of desert pavements: Geology, v. 15, p. 504-508.

McGovern, T.F., 1983, Evaluation of seismic reflection studies in the Yucca Mountain area, Nevada Test Site: U.S. Geological Survey Open-File Report 83-912, 58 p.
Menges, C.M., Taylor, E.M., Vadurro, Giovanni, Oswald, J.A., Cress, R., Murray, M., Lundstrom, S.C., Paces, J.B., and Mahan, S.A., 1997, Logs and paleoseismic interpretations from trenches 14C and 14D on the Bow Ridge fault, northeastern Yucca Mountain, Nye County, Nevada: U.S. Geological Survey Miscellaneous Field Studies Map MF-2311.

Menges, C.M., Vadurro, Giovanni, Giess, Robert, Coe, J.A., and Simonds, F.W., 1993, Stratigraphic evidence for multiple small Quaternary displacements on the Bow Ridge fault at northeast Yucca Mountain, Nye County, Nevada: Geological Society of America Abstracts with Programs, v. 25, p. 120.

Menges, C.M., Wesling, J.R., Whitney, J.W., Swan, F.H., Coe, J.A., Thomas, A.P., and Oswald, J.A., 1994, Preliminary results of paleoseismic investigation of Quaternary faults on eastern Yucca Mountain, Nye County, Nevada, in High Level Radioactive Waste Management: Proceedings of Fifth Annual International Conference, Las Vegas, Nevada, May 22-26, 1994, La Grange Park, Illinois, American Nuclear Society and American Society of Civil Engineers, v. 4, p. 2373-2390.

Moyer, T.C., and Geslin, J.K., 1995, Lithostratigraphy of the Calico Hills Formation and Prow Pass Tuff (Crater Flat Group) at Yucca Mountain, Nevada: U.S. Geological Survey Open-File Report 94-460, $59 \mathrm{p}$.

Muller, D.C., and Kibler, J.E., 1984, Preliminary analysis of geophysical logs from drill hole UE-25p \#1, Yucca Mountain, Nye County, Nevada: U.S. Geological Survey Open-File Report 84-649, 14 p.

Munsell Color Company, Inc., 1988, Munsell soil color charts: Baltimore, Maryland.

Neal, J.T., 1985, Location recommendation for surface facilities for the prospective Yucca Mountain nuclear waste repository: Albuquerque, New Mexico, Sandia National Laboratories Report SAND 84-2015, $54 \mathrm{p}$.

Neal, J.T., 1986, Preliminary validation of geology at site for repository surface facilities, Yucca Mountain, Nevada: Albuquerque, New Mexico, Sandia National Laboratories Report SAND85-0815, 48 p.

North American Commission on Stratigraphic Nomenclature, 1983, North American stratigraphic code: The American Association of Petroleum Geologists Bulletin, v. 67, no. 5, p. 841-875.

Oliver, H.W., Hardin, E.L., and Nelson, P.H., 1990, Status of data, major results, and plans for geophysical activities, Yucca Mountain Project: U.S. Department of Energy, YMP/90-38, 191 p.

Paces, J.B., Menges, C.M., Widmann, B., Wesling, J.R., Bush, C.A., Futa, K., Millard, H.T., Maat, P.B., and Whitney, J.W., 1994, Preliminary $\mathrm{U}$-series disequilibrium and thermoluminescence ages of surficial deposits and paleosols associated with Quaternary faults, eastern Yucca Mountain, in High Level Radioactive Waste Management: Proceedings of the Fifth International Conference, Las Vegas, Nevada, May 22-26, 1994, LaGrange Park, Illinois, American Nuclear Society of Civil Engineers, p. 2391-2401.

Pankrantz, L.W., 1982, Reconnaissance seismic refraction studies at Calico Hills, Wahmonie, and Yucca Mountain, southwest Nevada Test Site, Nye County, Nevada: U.S. Geological Survey Open-File Report 82-478, $25 \mathrm{p}$.

Peterson, F.F., Bell, J.W., Dorn, R.I., Ramelli, A.R., and Ku, T.-L, 
1995, Late Quaternary geomorphology and soils in Crater Flat, Yucca Mountain, southern Nevada: Geological Survey of America Bulletin, v. 107, no. 4, p. 379-395.

Ponce, D.A., 1993, Geophysical investigations of concealed faults near Yucca Mountain, southwest Nevada, in High Level Radioactive Waste Management: Proceedings of Fourth Annual International Conference, Las Vegas, Nevada, April 26-30, 1993, American Nuclear Society and American Society of Civil Engineers, p. 168-174.

Ponce, D.A., and Langenheim, V.E., 1994, Preliminary gravity and magnetic models across Midway Valley and Yucca Wash, Yucca Mountain, Nevada: U.S. Geological Survey Open-File Report 94-572, $25 \mathrm{p}$.

Reheis, M.C., 1987, Gypsic soils on the Kane alluvial fans, Big Horn County, Wyoming: U.S. Geological Survey Bulletin 1590-C, 39 p.

Reheis, M.C., Harden, J.W., McFadden, L.D., and Shroba, R.R., 1989, Development rates of late Quaternary soils, Silver Lake Playa, California: Soil Science Society of America Journal, v. 53, p. 1127-1140.

Reheis, M.C., Sowers, J.M., Taylor, E.M., McFadden, L.D., and Harden, J.W., 1992, Morphology and genesis of carbonate soils on the Kyle Canyon fan, Nevada, U.S.A.: Geoderma, v. 52, p. 303-342.

Reynolds, C.B., and Associates, 1985, Final report: 1985 repository surface facility seismic surveys, Yucca Mountain area, NTS, Nye County, Nevada, accessed May 15, 2000, at URL http://rms.ymp.gov/ scripts/get_record_images.com?MOL.19970415.0158/

Sarna-Wojcicki, A.M., Meyer, C.E., Wan, Elmira, and Soles, Stau, 1993, Age and correlation of tephra layers in Owens Lake drill core OL-92-1 and -2: U.S. Geological Survey Open-File Report 93-683, $11 \mathrm{p}$.

Sawyer, D.A., Fleck, R.J., Lanphere, M.A., Warren, R.G., Broxton, D.E., and Hudson, M.R., 1994, Episodic caldera volcanism in the Miocene southwestern Nevada volcanic field: Revised stratigraphic framework, ${ }^{40} \mathrm{Ar} /{ }^{39} \mathrm{Ar}$ geochronology, and implications for magmatism and extension: Geological Society of America Bulletin, v. 106, no. 10, p. 1304-1318.

Scott, R.B., and Bonk, J., 1984, Preliminary geologic map of Yucca Mountain, Nye County, Nevada, with geologic section: U.S. Geological Survey Open-File Report 84-494, scale 1:12,000.

Senterfit, R.M., Hoover, D.B., and Chornack, M.P., 1982, Resistivity sounding investigation by the Schlumberger method in the Yucca Mountain and Jackass Flats area, Nevada Test Site, Nevada: U.S. Geological Survey Open-File Report 82-1043, 38 p.

Simonds, F.W., Whitney, J.W., Fox, K.F, Ramelli, A.R., Yount, J.C., Carr, M.D., Menges, C.M., Dickerson, R., and Scott, R.B., 1995, Map showing fault activity in the Yucca Mountain area, Nye County, Nevada: U.S. Geological Survey Miscellaneous Investigations Series Map I-2520, scale 1:24,000.

Slate, J.L., 1991, Quaternary stratigraphy, geomorphology, and geochronology of alluvial fans, Fish Lake Valley, Nevada and California, in Reheis, M.C., Sarna-Wojcicki, A.M., Meyer, C.E., McKee, E.H., Slate, J.L., Burbank, D.M., Sawyer, T.L., and Pendall, E.G., contributing authors, Late Cenozoic Stratigraphy and Tectonics of Fish Lake Valley, Nevada and California-Road Log and Contributions to the Field Trip Guidebook, 1991 Pacific Cell of Friends of the Pleistocene: U.S. Geological Survey Open-File Report 91-290, $186 \mathrm{p}$.

Smith, C., and Ross, H.P., 1982, Interpretation of resistivity and induced polarization profiles with severe topographic effects, Yucca Mountain area, Nevada Test Site, Nevada: U.S. Geological Survey Open-File Report 82-182, $82 \mathrm{p}$.

Soil Survey Staff, 1951, Soil Survey Manual: U.S. Department of Agriculture Handbook No. 18, 503 p.

Soil Survey Staff, 1974, Definitions and abbreviations for soil descriptions: Portland, Oregon, U.S. Department of Agriculture Soil Conservation Service, West Technical Service Center, April, 1974, $14 \mathrm{p}$.

Soil Survey Staff, 1975, Soil taxonomy, a basic system of soil classification for making and interpreting soil surveys: U.S. Department of Agriculture, Handbook No. 436, 754 p.

Stewart, J.H., 1980, Regional tilt patterns of late Cenozoic basin-range fault blocks, Western United States: Geological Society of America Bulletin, v. 91, p. 460-464.

Stewart, J.H., 1988, Tectonics of the Walker Lane Belt, western Great Basin: Mesozoic and Cenozoic deformation in a zone of shear, in Ernst, W.G., ed., Metamorphism and Crustal Evolution of the Western United States: Englewood, New Jersey, Prentice-Hall, Rubey Volume VII, p. 683-713.

Stewart, J.H., 1992, Walker Lane Belt, Nevada and California-An overview, in Craig, S.D., ed., Structure, Tectonics, and Mineralization of the Walker Lane: Geological Society of Nevada, Walker Lane Symposium, Reno, Nevada, Proceedings, p. 1-16.

Stock, J.M., and Healy, J.H., 1988, Stress field at Yucca Mountain, Nevada, in Carr, M.D., and Yount, J.C., eds., Geologic and Hydrologic Investigations of a Potential Nuclear Waste Disposal Site at Yucca Mountain, Southern Nevada: U.S. Geological Survey Bulletin 1790, p. 87-93.

Swadley, W C, and Hoover, D.L., 1983, Geology of faults exposed in trenches in Crater Flat, Nye County, Nevada: U.S. Geological Survey Open-File Report 83-608, $15 \mathrm{p}$.

Swadley, W C, Hoover, D.L., and Rosholt, J.N., 1984, Preliminary report on late Cenozoic faulting and stratigraphy in the vicinity of Yucca Mountain, Nye County, Nevada: U.S. Geological Survey Open-File Report 84-788, $42 \mathrm{p}$.

Szabo, B.J., Carr, W.J., and Gottschall, W.C., 1981, Uranium-thorium dating of Quaternary accumulations in the Nevada Test Site region, southern Nevada: U.S. Geological Survey Open-File Report 81-119, $35 \mathrm{p}$.

Taylor, E.M., 1986, Impact of time and climate on Quaternary soils in the Yucca Mountain area of the Nevada Test Site: Boulder, University of Colorado, M.S. thesis, $217 \mathrm{p}$.

Taylor, E.M., and Huckins, H.E., 1986, Carbonate and opaline silica fault-filling on the Bow Ridge fault, Yucca Mountain, NevadaDeposition from pedogenic processes or upwelling ground water: Geological Society of America Abstracts with Programs, v. 18, no. 5, p. 418.

Taylor, E.M., and Huckins, H.E., 1995, Lithology, fault displacement, 
and origin of secondary calcium carbonate and opaline silica at trenches 14 and 14D on the Bow Ridge fault at Exile Hill, Nye County, Nevada: U.S. Geological Survey Open-File Report 93-477, $38 \mathrm{p}$.

U.S. Department of Energy, 1988, Site characterization plan: Washington, D.C., DOE/RW-0199, Office of Civilian Radioactive Waste Management.

U.S. Department of Energy, 1995, Site Atlas, Yucca Mountain, Nye County, Nevada: U.S. Department of Energy Remote Sensing Laboratory, Yucca Mountain Site Characterization Project, 1995, v. 2 , sheets $10,11,16$, and 17 [1:6,000-scale series].

U.S. Geological Survey, 1984, A summary of geologic studies through January 1, 1983, of a potential high-level radioactive waste repository site at Yucca Mountain, southern Nye County, Nevada: U.S. Geological Survey Open-File Report 84-792.

Wells, S.G., McFadden, L.D., and Dohrenwend, J.C., 1987, Influence of late Quaternary climatic changes on geomorphic and pedogenic processes on a desert piedmont, eastern Mojave Desert, California: Quaternary Research, v. 27, p. 130-146.

Wells, S.G., McFadden, L.D., and Harden, J., 1990, Preliminary results of age estimations and regional correlations of Quaternary alluvial fans within the Mojave Desert in southern California, in Reynolds, R.E., Wells, S.G., and Brady, R.H., compilers, At the End of the Mojave-Quaternary Studies in the Eastern Mojave Desert: Redlands, California, San Bernardino County Museum Association, p. $45-54$.
Wells, S.G., McFadden, L.D., Olinger, C.T., and Poths, J., 1994, Use of cosmogenic ${ }^{3} \mathrm{He}$ to understand desert pavement formation, in McGill, S.F., and Ross, T.M., eds., Geologic Investigations of an Active Margin: Geological Society of America Cordilleran Section Guidebook, Redlands, California, San Bernardino County Museum Association, p. 201-205.

Wesling, J.R., Bullard, T.F., Swan, F.H., Perman, R.C., Angell, M.M., and Gibson, J.D., 1992, Preliminary mapping of surficial geology of Midway Valley, Yucca Mountain, Nye County, Nevada: Sandia National Laboratories Report SAND91-0607, 55 p., 6 plates, scale 1:6,000.

Whitney, J.W., and Muhs, D.R., 1991, Quaternary movements on the Paintbrush Canyon-Stagecoach Road fault system, Yucca Mountain, Nevada: Geological Survey of America Abstracts with Programs, v. 23, no. 5, p. 47.

Whitney, J.W., Swadley, W C, and Shroba, R.R., 1985, Middle Quaternary sand ramps in the southern Great Basin, California and Nevada: Geological Society of America Abstracts with Programs, v. 17, p. 750. 


\section{Appendix-Soil-Profile Descriptions}

The degree of soil-profile development is one of the most useful parameters for correlating landforms, geomorphic surfaces, and surficial deposits of similar ages and for assessing the relative ages of these features. Soil development is affected over time by factors that include parent material, climate, vegetation, slope position, and eolian influx of carbonates and salts (Jenny, 1941; Birkeland, 1984). Although it is unlikely that all of these factors have been constant during the Quaternary, it can be assumed that they have similarly affected the development of a suite of soils through time. A suite of related soils on successively older relict and (or) buried surfaces, termed a soil chronosequence, is characterized by systematic differences in the degree of profile development that result primarily from systematic differences in age. Soil chronosequences have been developed in many arid and semiarid areas of the Western United States and abroad (McFadden, 1982; Dan, 1983; Abdou and others, 1984; Birkeland, 1984; Machette, 1985; Taylor, 1986; Reheis, 1987; Wells and others, 1987; McFadden, 1988; Reheis and others, 1989; Harden, Slate, and others, 1991; Harden, Taylor, Hill, and others, 1991; Harden, Taylor, Reheis, and others, 1991; Reheis and others, 1992).

This Appendix presents detailed field descriptions of the soils that were exposed in various soil test pits and trenches in Midway Valley, Yucca Mountain, Nevada. Soils data were used to corroborate the relative age assignments of map units that are based on post-depositional surface modifications, such as accumulation of desert varnish on surface clasts, rubification of the bottoms of surface clasts, reduction of initial depositional bar-and-swale relief, weathering of surface clasts, and other features such as degree of fluvial dissection and distinctive vegetation assemblages. To assess the variability in soil development, at least two soil profiles were described for each of the principal stratigraphic units delineated by Wesling and others (1992).

The age of the deposits is the only major soil-forming factor that varies appreciably among the soils studied. All soil profiles were described within Midway Valley, which encompasses a relatively small area of less than $10 \mathrm{~km}^{2}$. Local relief within the study area is about $150 \mathrm{~m}$, and elevations of soil pits do not differ by more than about $80 \mathrm{~m}$. The climate of the area is arid, thermic, and is assumed to be relatively constant within the valley. Desert shrub and grass assemblages appear to be relatively uniform; however, there is some variability in vegetation assemblages among map units of different ages. Soil profiles are developed in alluvial fan and colluvial deposits consisting of moderately to poorly sorted gravel and sand, which are derived from bedrock source areas containing silicic ash-flow tuffs (primarily the Tiva Canyon Tuff) and rhyolites (Fortymile Canyon assemblage). Eolian influx of carbonate, salts, and silt is a major source of secondary constituents within the soil. Most alluvial soil profiles were described on alluvial fan surfaces that slope $4^{\circ}$ or less in an easterly to southerly direction.

Soil profiles were described in the field according to nomenclature of the Soil Survey Staff (1951, 1974, 1975), Birkeland (1984), and Birkeland and others (1991). A summary of the physical properties described are presented in Birkeland (1984). These properties include depth, color, consistency, texture, and structure of the soil horizon; the presence, thickness, and abundance of clay films; the presence of carbonates and soluble salts; the cementation of the soil; visual estimates of volume percent of clasts larger than $2 \mathrm{~mm}$ based on American Geological Institute data sheets (Dietrich and others, 1982); and the nature and distinctness of boundaries between soil horizons. Supplementary properties described for some horizons include the presence of roots, pores, animal burrows, iron oxide staining, manganese oxide staining, and weathering characteristics of clasts greater than $2 \mathrm{~mm}$.

The stratigraphy of the near-surface deposits at each of the described locations is summarized in table A1, which also lists the geographic coordinates for the measured profiles. The locations of the soil pits are shown in figure A1, and the soilprofile descriptions are presented in table A2. 

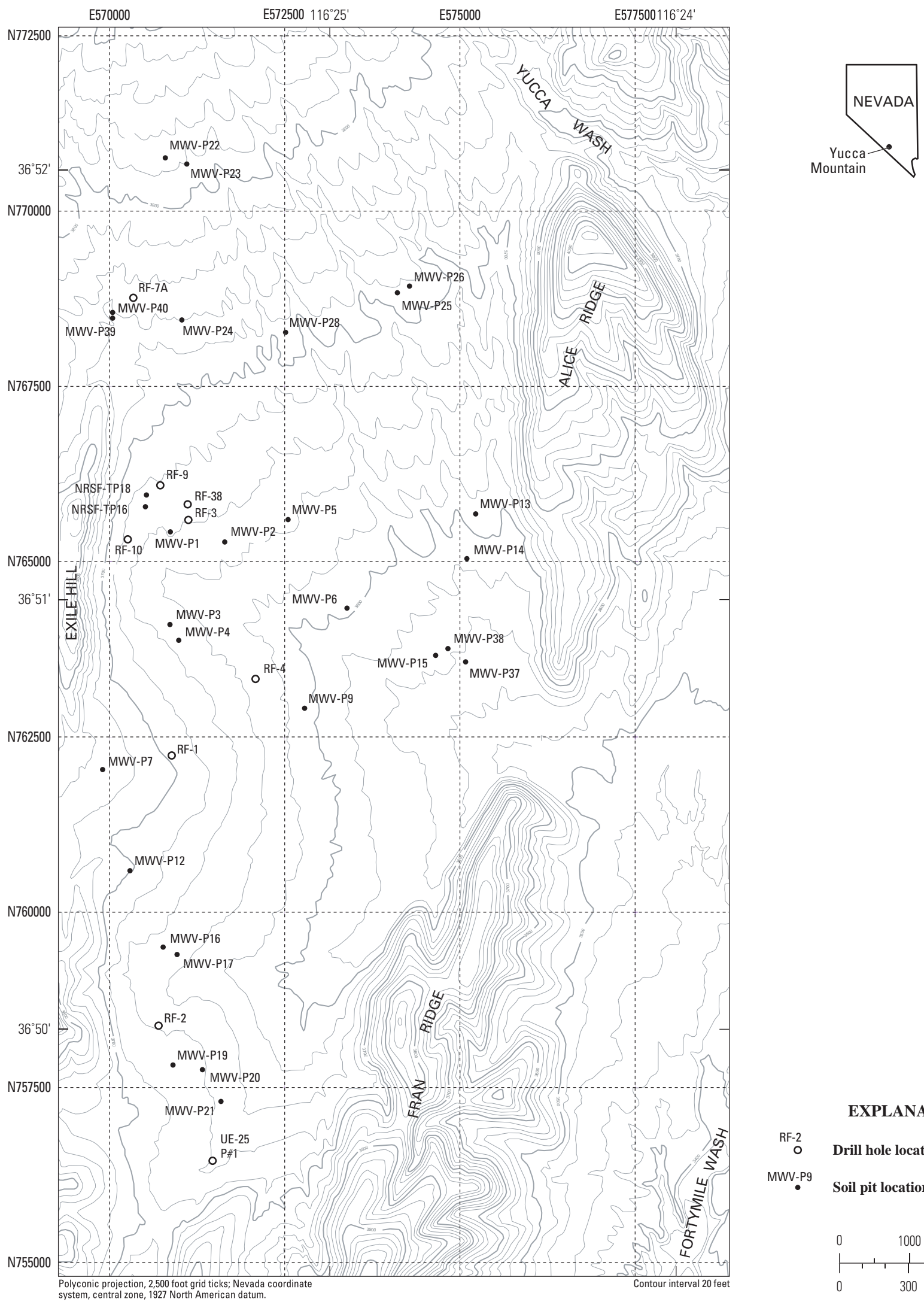

EXPLANATION

RF-2
O

Drill hole location and number

MWV-Pg

Soil pit location and number

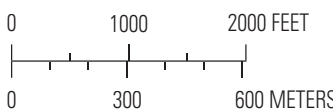

Figure A1. Locations of soil test pits and boreholes in Midway Valley. 
Table A1. Soil-pit characteristics and locations in Midway Valley.

[Descriptions of soil profiles are given in table A2. --, no data]

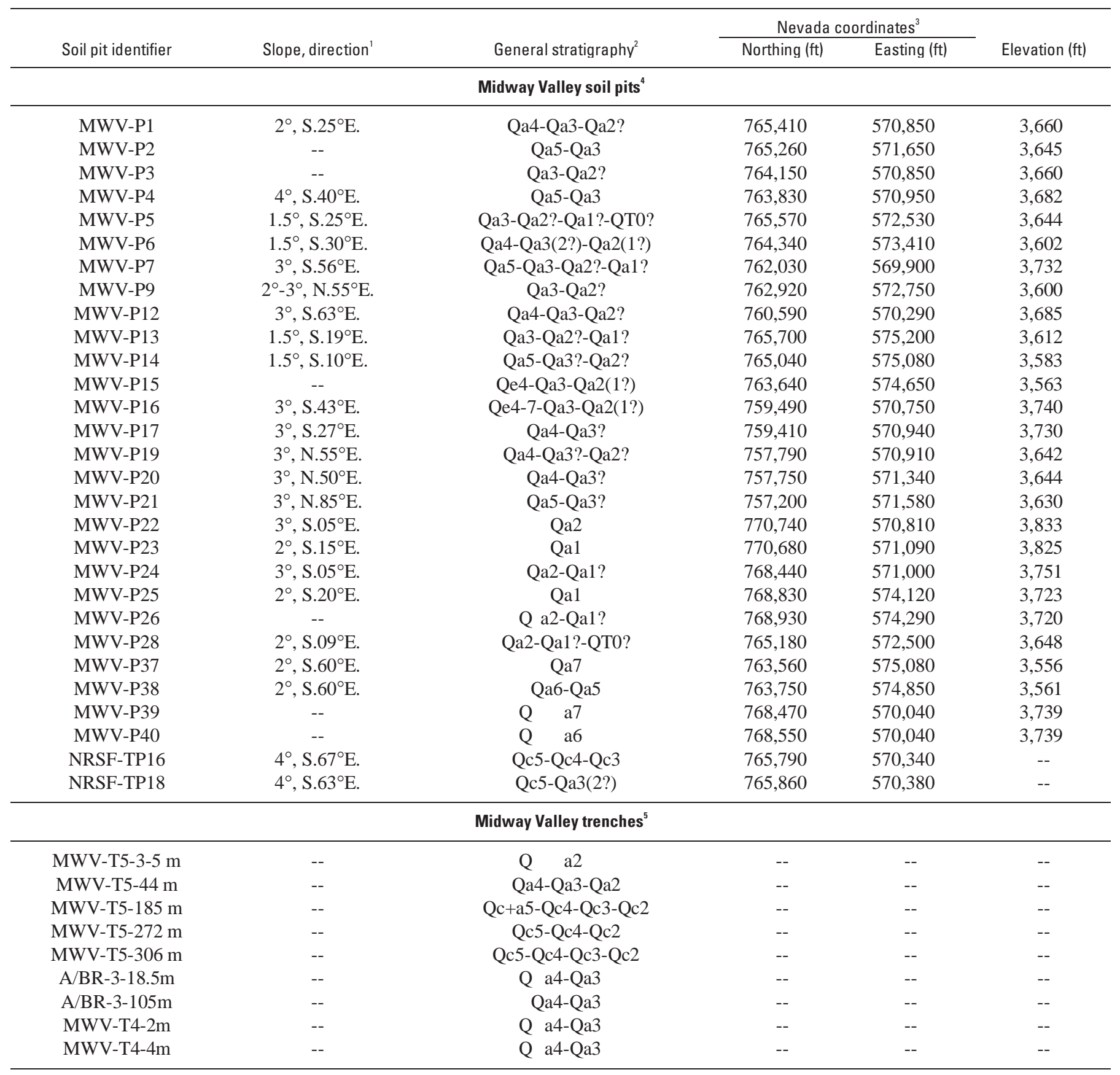

Notes:

${ }^{1}$ Slope direction measured from 1:1,200-scale map with $2 \mathrm{ft}$ contour interval.

${ }^{2} \mathrm{~A}$ unit designation followed by a queried number in parentheses, such as "Qa4(3?)", indicates that the unit probably is the designation given outside the parentheses, a correlation with the queried unit inside the parentheses is also possible but less likely. A query behind a unit designation, such as "Qa2?", indicates that the unit designation is generally based on stratigraphic position.

${ }^{3}$ Distances rounded off to the nearest ten feet.

${ }^{4}$ Locations of Midway Valley soil pits are shown in figure A1.

${ }^{5}$ Locations of soil profiles for trenches MWV-T5, A/BR-3, and MWV-T4 are shown in plates 4, 7, and 5, respectively. 
Table A2. Soil-profile descriptions for Midway Valley. ${ }^{1}$

[Abbreviations are given at the end of the table]

\begin{tabular}{|c|c|c|c|c|c|c|c|c|c|c|c|c|}
\hline \multirow[b]{2}{*}{ Horizon } & \multirow{2}{*}{$\begin{array}{l}\text { Depth } \\
\text { (cm) }\end{array}$} & \multicolumn{2}{|c|}{ Color $^{2}$} & \multirow[b]{2}{*}{ Texture } & \multirow[b]{2}{*}{ Structure } & \multicolumn{2}{|c|}{ Consistency } & \multirow[b]{2}{*}{ Clay films } & \multirow[b]{2}{*}{$\mathrm{CaCO}_{3}{ }^{3}$} & \multirow{2}{*}{$\begin{array}{l}\mathrm{Hcl} \\
\mathrm{Rxn}\end{array}$} & \multirow{2}{*}{$\begin{array}{c}\text { Cemen- } \\
\text { tation }\end{array}$} & \multirow[b]{2}{*}{ Boundary } \\
\hline & & Moist & Dry & & & Dry & Wet & & & & & \\
\hline \multicolumn{13}{|c|}{ SOIL PIT MWV-P1 } \\
\hline Avk & $0-8$ & 10YR 4/4 & 10YR 7/3 & sicl & $3 \mathrm{~m}-\mathrm{c} \mathrm{pl}$ & sh & $\mathrm{s}, \mathrm{p}$ & N.O. & N.O. & ve-e & -- & aw \\
\hline Bwk/Avk & $8-38$ & 10YR 5.5/3 & 10YR 6.5/3 & sicl & $2 \mathrm{f}-\mathrm{m} \mathrm{sbk}$ & so & $\mathrm{s}$ & $1 \mathrm{n}$ po & N.O. & ve & -- & aw \\
\hline 2Btkq1b & $38-61$ & $7.5 \mathrm{YR} 4 / 4$ & $7.5 \mathrm{YR} 7 / 4$ & fmsl & $3 \mathrm{f}-\mathrm{m} \mathrm{sbk}$ & h-vh & ss, ps & 2 n-mk pf & I- & ve & -- & aw \\
\hline 2Btkq2b & $61-105$ & $7.5 \mathrm{YR} 4 / 4$ & $7.5 \mathrm{YR} 7 / 4$ & $\mathrm{msl}$ & $2 \mathrm{f}-\mathrm{m}$ abk & sh-h & so, po & $1 \mathrm{npf}$ & II-III & e-es & -- & gw \\
\hline $2 \mathrm{Bkqb}$ & $105-142$ & 10 YR 5/6 & 10 YR $8 / 3$ & lcos & $\mathrm{m}$ & h-vh & so, po & N.O. & II+ & e-es & -- & $\mathrm{a}-\mathrm{cw}$ \\
\hline $2 \mathrm{Ckqb}$ & $142-194$ & $10 Y R 4 / 4$ & $10 Y R 7 / 3$ & lcos & $\mathrm{sg}$ & lo & so, po & N.O. & I & $\mathrm{e}$ & -- & aw \\
\hline $3 \mathrm{Bkq} 1 \mathrm{~b} 2$ & $194-245$ & $10 Y R$ 5/4 & $10 Y R 7 / 4$ & $1 \cos$ & $1 \mathrm{c} \mathrm{pl}$ & $\mathrm{h}-\mathrm{vh}$ & so, po & N.O. & II+ & es & -- & $\mathrm{cw}$ \\
\hline $3 \mathrm{Bkq} 2 \mathrm{~b} 2$ & $245-285$ & $10 Y R 4 / 6$ & $10 Y R 6 / 6$ & $1 \mathrm{fms}$ & m-sg & sh-h & so, po & N.O. & I & $\mathrm{e}$ & -- & gw \\
\hline 3Bkq3b2 & $285-350+$ & $10 Y R$ 4/6 & $10 \mathrm{YR} 7 / 3$ & $1 \mathrm{~ms}$ & m-sg & lo & so, po & N.O. & $\mathrm{I}+$ & $\mathrm{e}$ & -- & -- \\
\hline \multicolumn{13}{|c|}{ SOIL PIT MWV-P2 } \\
\hline $\mathrm{A}$ & $0-9$ & $10 \mathrm{YR} 4 / 3$ & $10 \mathrm{YR} 6 / 2$ & fsl & $2 \mathrm{f}-\mathrm{m} \mathrm{gr}$ & so & so, po & N.O. & N.O. & eo & -- & aw \\
\hline $\mathrm{Bw}$ & $9-28$ & $10 Y R \quad 4 / 3$ & $10 Y R 6 / 3$ & fsl & $2 \mathrm{f}-\mathrm{m} \mathrm{gr}$ & so & ss, ps & N.O. & N.O. & eo & -- & $\mathrm{cw}$ \\
\hline Bwk & $28-60$ & $10 Y R 4 / 4$ & 10 YR $7 / 3$ & fsl & $1 \mathrm{fgr}$ & so & ss, ps & N.O. & I+ & $\mathrm{e}$ & -- & aw \\
\hline 2Btkqb & $60-80$ & $7.5 \mathrm{YR} 5 / 6$ & $7.5 \mathrm{YR} 6 / 6$ & fsl & $3 \mathrm{f} \mathrm{sbk}$ & $\mathrm{sh}$ & ss-s, ps & $1-2 \mathrm{n} \mathrm{pf}, \mathrm{co}$ & I & $\mathrm{e}$ & -- & $a-c$ w-b \\
\hline $2 \mathrm{Kqb}$ & $80-118$ & $10 \mathrm{YR} 7 / 3$ & 10 YR $8 / 2$ & $1 \cos -\cos l$ & $\mathrm{~m}$ & $\mathrm{vh}$ & ss, po & N.O. & IV & ev & -- & aw \\
\hline $2 \mathrm{Bkq} 1 \mathrm{~b}$ & $118-140$ & $10 Y R$ 5/4 & $10 \mathrm{YR} 7 / 2$ & $1 \cos$ & $\mathrm{sg}$ & lo & so, po & N.O. & II+ & es & -- & $\mathrm{cw}$ \\
\hline $2 \mathrm{Bkq} 2 \mathrm{~b}$ & $140-175$ & $10 Y R$ 5/4 & $10 \mathrm{YR} 7 / 2$ & $\cos$ & $\mathrm{sg}$ & lo-so & so, po & N.O. & III- & $\mathrm{e}$ & -- & $\mathrm{cw}$ \\
\hline $2 \mathrm{Cqb}$ & $175-200$ & $10 \mathrm{YR} 4 / 3$ & $10 \mathrm{YR} 6 / 3$ & $\cos$ & sg & lo & so, po & N.O. & N.O. & eo & -- & aw \\
\hline 3BCkqb2 & $200-300+$ & $10 \mathrm{YR} 4 / 4$ & 10 YR $6 / 3$ & $\mathrm{msl}$ & sg & lo, so & so, ps & N.O. & I-II & $\mathrm{e}$ & -- & -- \\
\hline
\end{tabular}

\begin{tabular}{|c|c|c|c|c|c|c|c|c|c|c|c|c|}
\hline Avk & $0-7$ & $10 Y R 4 / 3$ & 10YR 7/3 & sicl & $3 \mathrm{~m} \mathrm{pl}$ & $\mathrm{sh}$ & $\mathrm{s}, \mathrm{p}$ & N.O. & N.O. & $\mathrm{e}$ & -- & aw \\
\hline Bwk & $7-20$ & 10YR 4/4 & 10YR 6/3 & sl-1 & 1 f-m gr & so & ss, ps & N.O. & I- & es & -- & aw \\
\hline 2Btkq1 & $20-53$ & 10YR 5/4 & 10YR 6/6 & fscl & $\begin{array}{c}1^{\circ} 3 \mathrm{f}-\mathrm{m} \mathrm{abk} \\
2^{\circ} 1 \mathrm{~m} \mathrm{pl}\end{array}$ & $\mathrm{h}$ & $\mathrm{s}, \mathrm{p}$ & $1-2 \mathrm{n} \mathrm{pf}$, co & I & ve & -- & aw \\
\hline 2Btkq2 & $53-70$ & 10YR 5/4 & 10YR 6/6 & fsl-1 & $2 \mathrm{~m} \mathrm{sbk}$ & $\mathrm{sh}$ & ss, ps & $\begin{array}{l}1 \mathrm{n} \mathrm{pf}, \\
2 \mathrm{n} \mathrm{br}\end{array}$ & I- & ve & -- & $\mathrm{cw}$ \\
\hline 2Btkq3 & $70-92$ & $10 Y R$ 4/4 & $10 Y R 6 / 4$ & $\mathrm{msl}$ & $1 \mathrm{~m} \mathrm{sbk}$ & h-vh & so, po & $\mathrm{vl} \mathrm{n} \mathrm{pf}$ & II- & ve & -- & cs \\
\hline 2Bkq1 & $92-106$ & 10YR 5/4 & $10 Y R 7 / 3$ & $\mathrm{msl}$ & $2 \mathrm{f} \mathrm{gr}$ & $\mathrm{sh}$ & so, po & N.O. & II+ & ev & -- & cs \\
\hline 2Bkq2 & $106-148$ & 10YR 5/4 & 10YR 7/3 & fsl & $\mathrm{m}$ & so & $\mathrm{ss}, \mathrm{ps}$ & N.O. & II & ev & -- & cs \\
\hline $2 \mathrm{Bkq} 3$ & $148-190$ & $10 Y R$ 4/4 & 10YR 6.5/3.5 & fsl & sg & lo-so & so, ps & N.O. & I & es & -- & $\mathrm{cs}$ \\
\hline $2 \mathrm{Ckq} 1$ & $190-225$ & $10 Y R$ 4/4 & 10YR 6.5/3.5 & lcos & sg & lo-so & so, po & N.O. & I- & ve-e & -- & cs \\
\hline $2 \mathrm{Ckq} 2$ & $225-285$ & $10 Y R$ 4/4 & 10YR 6/3 & $\operatorname{lms}$ & $\mathrm{m}$ & so-sh & so, po & N.O. & I+ & $\mathrm{e}$ & -- & $\mathrm{cw}$ \\
\hline $2 \mathrm{Ckq} 3$ & $285-330+$ & $10 Y R$ 4/4 & 10YR $6.5 / 3$ & $1 \mathrm{~ms}$ & sg & lo & so, po & N.O. & I- & e & -- & -- \\
\hline
\end{tabular}




\begin{tabular}{|c|c|c|c|c|c|c|c|c|c|c|c|c|}
\hline \multirow[b]{2}{*}{ Horizon } & \multirow{2}{*}{$\begin{array}{l}\text { Depth } \\
\text { (cm) }\end{array}$} & \multicolumn{2}{|c|}{ Color $^{2}$} & \multirow[b]{2}{*}{ Texture } & \multirow[b]{2}{*}{ Structure } & \multicolumn{2}{|c|}{ Consistency } & \multirow[b]{2}{*}{ Clay films } & \multirow[b]{2}{*}{$\mathrm{CaCO}_{3}{ }^{3}$} & \multirow{2}{*}{$\begin{array}{l}\mathrm{Hcl} \\
\mathrm{Rxn}\end{array}$} & \multirow{2}{*}{$\begin{array}{l}\text { Cemen- } \\
\text { tation }\end{array}$} & \multirow[b]{2}{*}{ Boundary } \\
\hline & & Moist & Dry & & & Dry & Wet & & & & & \\
\hline \multicolumn{13}{|c|}{ SOIL PIT MWV-P4 } \\
\hline A & $0-5$ & $10 \mathrm{YR} 4 / 2$ & 10YR 6/3.5 & lfs & sg & lo & so, po & N.O. & N.O. & eo & -- & as \\
\hline $\mathrm{Bw}$ & $5-25$ & $10 \mathrm{YR} 4 / 3$ & 10YR 6/3 & lfs & 2 f-m sbk & so & so, po & N.O. & N.O. & eo & -- & $\mathrm{cw}$ \\
\hline Bwk & $25-50$ & $10 Y R 4 / 3$ & 10YR 6/3 & lfms & $\begin{array}{c}1^{\circ} 1 \mathrm{f}-\mathrm{m} \mathrm{sbk} \\
2^{\circ} \mathrm{sg}\end{array}$ & so & so, po & N.O. & I & ve & -- & $\mathrm{cw}$ \\
\hline Bkq & $50-100$ & $10 Y R 4 / 3$ & 10YR 6/3 & fms & sg & lo & so, po & N.O. & I & ve & -- & aw \\
\hline 2Btjkqb & $100-137$ & 10YR 4/4 & 10YR 7/4 & fmsl & $2 \mathrm{~m}$ abk & $\mathrm{h}$ & so, po & vl n pf, co & $\mathrm{I}+$ & ve & -- & $\mathrm{cw}$ \\
\hline 2Bkqb & $137-170$ & 10YR 4/4 & 10YR 6/4 & fmsl & m-sg & lo & so, po & N.O. & I- & ve-e & -- & $\mathrm{cw}$ \\
\hline $2 \mathrm{Ckqb}$ & $170-235$ & 10YR 4/6 & 10YR 6/6 & fsl & $\mathrm{m}$ & lo & so, po & N.O. & $\mathrm{I}-$ & eo & -- & gw \\
\hline $3 \mathrm{Ckqb}$ & $235-370+$ & $10 \mathrm{YR} 4 / 4$ & 10YR 6/4 & $\operatorname{lms}$ & $\mathrm{sg}$ & lo & so, po & N.O. & I- & ve & -- & -- \\
\hline \multicolumn{13}{|c|}{ SOIL PIT MWV-P5 } \\
\hline Avk & $0-8$ & 10YR 4/4 & $10 Y R 7 / 3$ & sicl & $3 \mathrm{vc} \mathrm{pl}$ & sh & ss-s, p & N.O. & N.O. & ve & -- & as \\
\hline Bwk1 & $8-15$ & 10YR 4/4 & $10 \mathrm{YR} 6 / 3$ & 1 & $2 \mathrm{f}-\mathrm{m} \mathrm{sbk}$ & so & ss, ps & N.O. & I & es & -- & $\mathrm{cs}$ \\
\hline Bwk2 & $15-28$ & 10YR 4/4 & 10YR 6/3 & fsl & $1 \mathrm{f} \mathrm{sbk}$ & so & vss, vps & N.O. & I & es & -- & aw \\
\hline 2Bwkb & $28-40$ & $10 Y R 4 / 4$ & 10YR 6/4 & fsl & $1-2 \mathrm{f} \mathrm{cpr}$ & sh & ss, ps & $1 \mathrm{n} \mathrm{co}$ & I- & es & -- & as \\
\hline $\begin{array}{c}\text { 3Btkqmb2/ } \\
\text { 3Kqmb2 }\end{array}$ & $40-80$ & 10YR 4/4 & 10YR 7/6 & sl & $\begin{array}{l}1^{\circ} 3 \mathrm{~m}-\mathrm{c} \mathrm{pl} \\
2^{\circ} 1 \mathrm{c} \mathrm{abk}\end{array}$ & $\mathrm{vh}$ & so, po & $3 \mathrm{mk} \mathrm{pf}$ & $\mathrm{I}+$ & ve & $\mathrm{cw}$ & $\mathrm{cs}$ \\
\hline 3Btkqmb2 & 80-99 & 10YR 4/4 & 10YR 7/6 & sl & $1 \mathrm{~m}-\mathrm{c} \mathrm{pl}$ & vh & so, po & $\mathrm{vl} \mathrm{n} \mathrm{pf}$ & I+ & ve & $\mathrm{cw}$ & $\mathrm{cw}$ \\
\hline 3Bkqb2 & 99-128 & 10YR 4/4 & 10YR 6/4 & sl & $\mathrm{m}$ & $\mathrm{h}$ & so, po & N.O. & I & ve & -- & as \\
\hline 4Bkq1b3 & $128-168$ & 10YR 7/4 & 10YR 8/4 & ls & $1 \mathrm{~m} \mathrm{sbk}$ & sh-h & so, po & N.O. & II+-III & ev & -- & $\mathrm{cw}$ \\
\hline $4 \mathrm{Bkq} 2 \mathrm{~b} 3$ & $168-200$ & 10YR 6/4 & 10YR 7/3 & $\mathrm{s}$ & $\mathrm{m}$ & lo & so, po & N.O. & I & ev & -- & cs \\
\hline 4BCkqb3 & $200-235$ & 10YR 5/4 & 10YR 8/4 & mcos & sg & lo-so & so, po & N.O. & I- & es & -- & cs \\
\hline 5Bkqb4 & $235-268+$ & $10 \mathrm{YR} 4 / 4$ & 10YR 7/4 & ls & $\begin{array}{c}1^{\circ} \mathrm{m} \\
2^{\circ} 1 \mathrm{f}-\mathrm{m} \text { gr }\end{array}$ & so & so, po & N.O. & $\mathrm{I}+$ & es & -- & -- \\
\hline \multicolumn{13}{|c|}{ SOIL PIT MWV-P6 } \\
\hline Avk & $0-6$ & 10YR 5/4 & 10YR 7/3 & 1 & $3 \mathrm{~m}-\mathrm{c} \mathrm{pl}$ & so & ss, ps & N.O. & N.O. & es & -- & cs \\
\hline 2Btjkq & $6-10$ & 10YR 4/4 & $10 Y R 7 / 3$ & 1 & $3 \mathrm{f} \mathrm{sbk}$ & $\mathrm{sh}$ & ss, ps & $1 \mathrm{n} \mathrm{pf}$ & N.O. & es & -- & cs \\
\hline $2 \mathrm{Btkq}$ & $10-20$ & 7.5YR 4.5/6 & 7.5YR 7/4 & $\mathrm{cl}$ & $2 \mathrm{~m} \mathrm{sbk}$ & so-sh & ss-s, p & $\begin{array}{l}1 \mathrm{n} \mathrm{pf} \\
1 \mathrm{n} \mathrm{po}\end{array}$ & I & es & -- & cs \\
\hline 2Btjkq1 & $20-28$ & 7.5YR 5/6 & 7.5YR 7/4 & 1 & $1 \mathrm{~m} \mathrm{sbk}$ & so & ss, ps & $\begin{array}{l}\text { v1 n pf, } \\
\text { v1 n po }\end{array}$ & I & es & -- & cs \\
\hline 2Btjkq2 & $28-37$ & 7.5YR 5/8 & 7.5YR 6/6 & sl & $2 \mathrm{f}-\mathrm{m} \mathrm{sbk}$ & so & ss, ps & $\mathrm{v} 1 \mathrm{n} \mathrm{pf}$ & I & es & -- & aw \\
\hline $3 \mathrm{Kqb}$ & $37-90$ & 10YR 6/4 & 10YR 8/3 & $\mathrm{sl}$ & v1 m pl & $\mathrm{vh}$ & so, po & N.O. & III+IV & ev & -- & gs \\
\hline 3Bkq1b & $90-120$ & 10YR 5/6 & $10 \mathrm{YR} 8 / 3$ & lcos & $\mathrm{sg}$ & lo & so, po & N.O. & II+ & ev & -- & gw \\
\hline $3 \mathrm{Bkq} 2 \mathrm{~b}$ & $120-185$ & 10YR 5/3 & 10YR 7/2 & $\cos$ & $\mathrm{sg}$ & lo & so, po & N.O. & II & ev & -- & $\mathrm{cw}$ \\
\hline 3BCkqb & $185-205$ & $10 Y R 4 / 3$ & 10YR 7/3 & lcos & $\mathrm{sg}$ & lo & so, po & N.O. & $\mathrm{I}$ & es & -- & aw \\
\hline $4 \mathrm{Bkq} 1 \mathrm{~b} 2$ & $205-235$ & 7.5YR 4/6 & 7.5YR 7/4 & ls & $1 \mathrm{~m}-\mathrm{c} \mathrm{sbk}$ & sh & so, po & N.O. & I+ & ve & -- & $\mathrm{cb}$ \\
\hline
\end{tabular}


Table A2. So profile descriptions for Midway Valley_Continued.

\begin{tabular}{|c|c|c|c|c|c|c|c|c|c|c|c|c|}
\hline \multirow[b]{2}{*}{ Horizon } & \multirow{2}{*}{$\begin{array}{l}\text { Depth } \\
\text { (cm) }\end{array}$} & \multicolumn{2}{|c|}{ Color ${ }^{2}$} & \multirow[b]{2}{*}{ Texture } & \multirow[b]{2}{*}{ Structure } & \multicolumn{2}{|c|}{ Consistency } & \multirow[b]{2}{*}{ Clay films } & \multirow[b]{2}{*}{$\mathrm{CaCO}_{3}{ }^{3}$} & \multirow{2}{*}{$\begin{array}{l}\mathrm{Hcl} \\
\mathrm{Rxn}\end{array}$} & \multirow{2}{*}{$\begin{array}{l}\text { Cemen- } \\
\text { tation }\end{array}$} & \multirow[b]{2}{*}{ Boundary } \\
\hline & & Moist & Dry & & & Dry & Wet & & & & & \\
\hline \multicolumn{13}{|c|}{ SOIL PIT MWV-P6_Continued } \\
\hline $4 \mathrm{Bkq} 2 \mathrm{~b} 2$ & $235-275$ & 10YR 5/4 & 10YR $7 / 3$ & ls & sg & lo & so, po & N.O. & $\mathrm{I}+$ & ev & -- & $\mathrm{cw}$ \\
\hline 4CBkqb2 & $275-285+$ & $10 Y R 4 / 3$ & 10YR $7 / 4$ & $\cos$ & $\mathrm{sg}$ & lo & so & N.O. & $\mathrm{I}+$ & ve & -- & -- \\
\hline \multicolumn{13}{|c|}{ SOIL PIT MWV-P7 } \\
\hline A & $0-5$ & $10 Y R 3 / 3$ & $10 Y R 5 / 3$ & fsl & $1 \mathrm{f} g r$ & lo-so & so, ps-p & N.O. & N.O. & eo & -- & as \\
\hline $\mathrm{Bw}$ & $5-20$ & $10 Y R 4 / 3$ & 10YR 6/3 & sl & $1 \mathrm{f} \mathrm{sbk}$ & so & so, ps & N.O. & N.O. & eo & -- & $\mathrm{cw}$ \\
\hline Bwk1 & $20-33$ & $10 \mathrm{YR} 4 / 3$ & $10 Y R 6 / 3$ & ls & $1 \mathrm{f} \mathrm{sbk}$ & so & so, ps & N.O. & N.O. & ve & -- & $\mathrm{cw}$ \\
\hline Bwk2 & $33-49$ & $10 Y R \quad 4 / 3$ & 10YR 6/3 & fsl & $1 \mathrm{f} \mathrm{gr}$ & lo-so & so, vps & N.O. & I & es & -- & gs \\
\hline $\mathrm{Bk}$ & 49-112 & $10 \mathrm{YR} 4 / 3$ & 10YR $6.5 / 3$ & fsl & sg & lo & so, ps & N.O. & I+ & es-ev & -- & aw \\
\hline 2Bkq1b & $112-154$ & 10YR 3/6 & $10 \mathrm{YR} 6 / 3$ & $1 \mathrm{~ms}$ & $2 \mathrm{~m} \mathrm{sbk}$ & $\mathrm{h}$ & so, po & $1 \mathrm{n} \mathrm{pf}$ & I & es & -- & $\mathrm{cs}$ \\
\hline $2 \mathrm{Bkq} 2 \mathrm{~b}$ & 154-192 & $10 Y R$ 4/4 & 10YR 6/4 & lfs & $\mathrm{m}$ & $\mathrm{h}$ & so, vps & N.O. & I- & ve & -- & $\mathrm{cw}$ \\
\hline $2 \mathrm{Bkq} 3 \mathrm{~b}$ & $192-218$ & $10 \mathrm{YR} 4 / 4$ & 10YR $7 / 4$ & ls & sg & lo & so, po & N.O. & I & e-es & -- & $\mathrm{cw}$ \\
\hline $2 \mathrm{Cqb}$ & $218-237$ & $10 Y R$ 4/4 & 10YR $7 / 4$ & $\operatorname{lms}$ & sg & lo & so, po & N.O. & N.O. & eo & -- & aw \\
\hline $3 \mathrm{Bkqb} 2$ & $237-307$ & 10 YR $5 / 3$ & $10 Y R 7 / 3$ & $\operatorname{lmcos}$ & $\mathrm{m}$ & $\mathrm{h}$ & so, po & N.O. & I+ & ev & -- & aw \\
\hline $4 \mathrm{Bkqb3}$ & $307-332+$ & $10 Y R$ 4/4 & $10 \mathrm{YR} 7 / 3$ & ls & $\mathrm{m}$ & $\mathrm{h}$ & so, po & N.O. & I- & ev & -- & -- \\
\hline
\end{tabular}

SOIL PIT MWV-P9

\begin{tabular}{|c|c|c|c|c|c|c|c|c|c|c|c|c|}
\hline $\mathrm{Av}$ & $0-5$ & -- & 10YR 7/3 & 1-sil & $1 \mathrm{~m} \mathrm{pl}$ & sh & ss, ps & N.O. & N.O. & eo-ve & -- & $\mathrm{cs}$ \\
\hline $\mathrm{Bt}$ & $5-35$ & -- & 7.5YR 5/4 & scl-1 & $2-3 \mathrm{~m}$ abk & $\mathrm{h}$ & $\mathrm{s}, \mathrm{p}$ & $2 \mathrm{mk}$ pf, po & N.O. & eo & -- & gw-b \\
\hline $2 \mathrm{Bt}$ & $35-60$ & -- & 7.5YR 6/4 & sl-1 & $2 \mathrm{f}-\mathrm{m}$ abk & $\mathrm{h}$ & ss, ps & $2 \mathrm{mk}$ pf, po & N.O. & eo-ve & -- & $\mathrm{gw}$ \\
\hline 3Btkq & $60-87$ & -- & 7.5YR 7/4 & ls & $1 \mathrm{f}-\mathrm{m}$ abk & sh & so, po & $2 \mathrm{n} \mathrm{pf,} \mathrm{co}$ & I-II & $\mathrm{e}$ & -- & gs \\
\hline $3 \mathrm{Bkq}$ & $87-110$ & -- & 7.5YR 6/6 & $\mathrm{s}$ & m-sg & $\mathrm{h}$ & so, po & N.O. & II + & e-es & -- & $\mathrm{cw}$ \\
\hline $4 \mathrm{Bkq}$ & $110-220$ & -- & 10YR 6/3 & $\mathrm{s}$ & sg & lo & so, po & N.O. & II & es & -- & gw \\
\hline $5 \mathrm{Kq}$ & $220-255$ & -- & 7.5YR 7/2 & $\mathrm{s}$ & $\mathrm{m}$ & $\mathrm{h}$ & so, po & N.O. & III- & $\mathrm{ev}$ & -- & $\mathrm{cb}$ \\
\hline $6 \mathrm{BCkq}$ & $255-330$ & -- & $10 Y R 7 / 3$ & $\mathrm{~s}$ & $\mathrm{sg}$ & lo-so & so, po & N.O. & II- & e-es & -- & aw \\
\hline $7 \mathrm{Bkqb}$ & $330-360+$ & -- & 7.5YR 7/3 & $\mathrm{s}$ & $\mathrm{m}-1 \mathrm{~m} \mathrm{sbk}$ & so-sh & so, po & N.O. & II- & e-es & -- & -- \\
\hline
\end{tabular}

\begin{tabular}{|c|c|c|c|c|c|c|c|c|c|c|c|c|}
\hline \multicolumn{13}{|c|}{ SOIL PIT MWV-P12 } \\
\hline Avk & $0-5$ & $10 Y R$ 4/4 & 10YR 5/3 & 1 & $3 \mathrm{c} \mathrm{pl}$ & so-sh & ss, ps & N.O. & N.O. & es & -- & as \\
\hline BAt & $5-15$ & 10YR 4/4 & 10YR 6/3 & 1 & $2 \mathrm{~m}-\mathrm{c} \mathrm{sbk}$ & $\mathrm{sh}$ & ss, ps & $\begin{array}{l}\text { 1n pf, } \\
\text { 3n po }\end{array}$ & N.O. & eo & -- & as \\
\hline 2Btkq & $15-42$ & 10-7.5YR 4/4 & $7.5 \mathrm{YR}$ & sicl & $\begin{array}{c}1^{\circ} 3 \mathrm{f}-\mathrm{m} \mathrm{sbk} \\
2^{\circ} 2 \mathrm{~m} \mathrm{c}\end{array}$ & sh-h & $\mathrm{s}, \mathrm{p}_{3}$ & $\begin{array}{c}3 \text { n-mk pf, } \\
\text { mk po }\end{array}$ & $\mathrm{I}-$ & ve & -- & as \\
\hline 2Btjkqb & $42-74$ & 7.5YR 4.5/6 & 7.5YR 7/4 & $\mathrm{sl}$ & $2 \mathrm{f}-\mathrm{m} \mathrm{sbk}$ & $\mathrm{h}$ & so, ps & $2 \mathrm{n}-\mathrm{mk} \mathrm{pf}$ & I & es & -- & $\mathrm{cw}$ \\
\hline $3 \mathrm{Bkq} 1 \mathrm{~b}$ & $74-100$ & 10YR 4/6 & 10YR 7/4 & $\operatorname{lms}$ & $1 \mathrm{f}-\mathrm{m} \mathrm{sbk}$ & $h-v h$ & so, po & $1 \mathrm{n} \mathrm{br}$ & II & ev & -- & $\mathrm{cs}$ \\
\hline $3 \mathrm{Bkq} 2 \mathrm{~b}$ & $100-128$ & $10 Y R$ 4/4 & 10YR 6/4 & $\operatorname{lms}$ & $1 \mathrm{f} \mathrm{sbk}$ & $\mathrm{h}$ & so, po & N.O. & I & ev & -- & $\mathrm{cs}$ \\
\hline $4 \mathrm{Bkqb}$ & $128-151$ & $10 Y R \quad 4 / 4$ & 7.5YR 7/4 & $\mathrm{fsl}$ & $1 \mathrm{f} \mathrm{sbk}$ & $h-v h$ & so, po & $\mathrm{v} 1 \mathrm{n} \mathrm{pf}$ & I & es & -- & $\mathrm{cW}$ \\
\hline
\end{tabular}




\begin{tabular}{|c|c|c|c|c|c|c|c|c|c|c|c|c|}
\hline \multirow[b]{2}{*}{ Horizon } & \multirow{2}{*}{$\begin{array}{l}\text { Depth } \\
(\mathrm{cm})\end{array}$} & \multicolumn{2}{|c|}{ Color $^{2}$} & \multirow[b]{2}{*}{ Texture } & \multirow[b]{2}{*}{ Structure } & \multicolumn{2}{|c|}{ Consistency } & \multirow[b]{2}{*}{ Clay films } & \multirow[b]{2}{*}{$\mathrm{CaCO}_{3}{ }^{3}$} & \multirow{2}{*}{$\begin{array}{l}\mathrm{Hcl} \\
\mathrm{Rxn}\end{array}$} & \multirow{2}{*}{$\begin{array}{l}\text { Cemen- } \\
\text { tation }\end{array}$} & \multirow[b]{2}{*}{ Boundary } \\
\hline & & Moist & Dry & & & Dry & Wet & & & & & \\
\hline \multicolumn{13}{|c|}{ SOIL PIT MWV-P12_Continued } \\
\hline 4BCkq1b & $151-195$ & $10 \mathrm{YR} 4 / 5$ & $10 Y R 6 / 4$ & lfs & $1 \mathrm{~m} \mathrm{sbk}$ & $\mathrm{h}$ & so, po & $\mathrm{v} 1 \mathrm{n} \mathrm{pf}$ & I & es & -- & $\mathrm{cw}$ \\
\hline $4 \mathrm{BCkq} 2 \mathrm{~b}$ & $195-240+$ & $10 Y R 4 / 5$ & $10 Y R 6 / 4$ & lfs & $1 \mathrm{f} \mathrm{sbk}$ & $\mathrm{h}$ & so, po & $\mathrm{v} 1 \mathrm{n} \mathrm{pf}$ & I & es & -- & -- \\
\hline \multicolumn{13}{|c|}{ SOIL PIT MWV-P13 } \\
\hline Avk & $0-8$ & $10 Y R 5 / 4$ & $10 Y R 7 / 3$ & 1 & $3 \mathrm{c} \mathrm{pl}$ & so-sh & ss, ps & N.O. & N.O. & es & -- & as \\
\hline Btkq & $8-22$ & $7.5 Y R$ 4/6 & $7.5 \mathrm{YR} 5 / 8$ & $\mathrm{c}$ & $2 \mathrm{~m} \mathrm{sbk}$ & $\mathrm{sh}$ & ss, ps & $\begin{array}{c}3 \text { n-mk pf, } \\
3 \text { n po }\end{array}$ & I & eo-ve & -- & aw \\
\hline $2 \mathrm{Kqb}$ & $22-51$ & 7.5YR 8/4 & $10 Y R 8 / 3$ & ls & $\mathrm{m}$ & $\mathrm{h}$ & so, po & N.O. & III & ev & -- & $\mathrm{cs}$ \\
\hline 2Bkq1b & $51-75$ & 10YR 7/4 & 7.5YR 8/2 & ls & $1 \mathrm{f}-\mathrm{m} \mathrm{pl}$ & $\mathrm{h}$ & so, po & N.O. & II+ & ev & -- & $\mathrm{cW}$ \\
\hline $2 \mathrm{Bkq} 2 \mathrm{~b}$ & $75-103$ & $10 Y R 7 / 4$ & 10 YR $8 / 2$ & ls & sg & lo & so, po & N.O. & $\mathrm{I}+$ & ev & -- & $\mathrm{cw}$ \\
\hline 2BCkqb & $103-180$ & $10 Y R 4 / 3$ & $10 Y R 7 / 3$ & $\cos$ & $\mathrm{sg}$ & lo & so, po & N.O. & I & ev & -- & aw \\
\hline 3Bkq1b2 & $180-230$ & $10 \mathrm{YR} 5 / 8$ & $7.5 \mathrm{YR} 7 / 4$ & $\cos$ & $\begin{array}{l}1^{\circ} 1 \mathrm{~m} \mathrm{pl} \\
2^{\circ} 1 \mathrm{f} \mathrm{abk}\end{array}$ & $\mathrm{vh}$ & so, po & N.O. & $\mathrm{I}+$ & ev & -- & $\mathrm{gw}$ \\
\hline $3 \mathrm{Bkq} 2 \mathrm{~b} 2$ & $230-260$ & $10 Y R 7 / 8$ & $10 Y R 8 / 4$ & $\operatorname{mcos}$ & $\mathrm{m}$ & $\mathrm{h}$ & so, po & N.O. & N.O. & ev & -- & $\mathrm{cw}$ \\
\hline 3Bqb2 & $260-314+$ & $10 Y R$ 4/6 & 10YR 6/6 & $\operatorname{mcos}$ & $\mathrm{m}$ & $\mathrm{h}$ & so, po & N.O. & I+ & ve & -- & -- \\
\hline \multicolumn{13}{|c|}{ SOIL PIT MWV-P14 } \\
\hline Av & $0-7$ & $10 \mathrm{YR} 4 / 3$ & $10 Y R 6 / 4$ & fsl & $1 \mathrm{f} \mathrm{pl}$ & so & so, ps & N.O. & N.O. & eo & -- & as \\
\hline 2Bwk & $7-23$ & $10 \mathrm{YR} 4 / 4$ & $10 \mathrm{YR} 6 / 3$ & fsl & $1 \mathrm{f} \mathrm{sbk}$ & so & so, ps & N.O. & N.O. & ve & -- & aw \\
\hline $2 \mathrm{Bkq}$ & $23-130$ & $10 Y R$ 4/6 & $10 Y R 7 / 3$ & fmsl & $\mathrm{sg}$ & lo & so, po & N.O. & I & es-ev & -- & aw \\
\hline $3 \mathrm{Ckqb}$ & $130-190$ & 7.5YR 4/6 & $7.5 \mathrm{YR} 7 / 4$ & ls & sg & lo-so & so, po & $1-2 \mathrm{npf}$ & I- & ve & -- & aw \\
\hline 4BCkqb2 & $190-242$ & 7.5YR 4.5/6 & $7.5 \mathrm{YR} 7 / 6$ & fsl & $\mathrm{m}$ & $\mathrm{h}$ & ss, ps & N.O. & I- & ve & -- & $\mathrm{cw}$ \\
\hline 4Cqb2 & $242-279+$ & 7.5YR 4/4 & 7.5 YR 7/4 & $\operatorname{lmcos}$ & $\mathrm{sg}$ & lo & so, po & N.O. & N.O. & eo & -- & -- \\
\hline \multicolumn{13}{|c|}{ SOIL PIT MWV-P15 } \\
\hline Avk & $0-7$ & $10 Y R \quad 4 / 3$ & $10 Y R 6 / 3$ & 1 & $3 \mathrm{c}-\mathrm{vc} \mathrm{pl}$ & so & ss, ps-p & N.O. & N.O. & ev & -- & as \\
\hline BAtvk & $7-11$ & $10 Y R 4 / 4$ & $10 Y R 7 / 4$ & -- & $\begin{array}{c}1^{\circ} 1 \mathrm{c} \mathrm{pl} \\
2^{\circ} 2 \mathrm{~m} \mathrm{sbk}\end{array}$ & sh & ss-s, p & 3 n-mk pf & N.O. & ve & -- & $\mathrm{cs}$ \\
\hline Btk & $11-19$ & $10 Y R 4 / 3$ & $10 Y R 7 / 3$ & $\mathrm{scl}$ & $2 \mathrm{~m} \mathrm{sbk}$ & sh & ss, ps & 3 n-mk pf, po & N.O. & $\mathrm{e}$ & -- & $\mathrm{cs}$ \\
\hline 2Btkq & $19-30$ & $10 Y R 4 / 4$ & 10YR $7 / 4$ & $\mathrm{scl}$ & $2 \mathrm{~m} \mathrm{sbk}$ & sh & so-ss, p & $1 \mathrm{n} \mathrm{pf}$ & I & es & -- & aw \\
\hline 3Btkqb & $30-44$ & 10YR 4/4 & $10 Y R$ 6/4 & $\mathrm{scl}$ & $2 \mathrm{f}-\mathrm{m}$ sbk & sh & ss, ps & $\begin{array}{l}1 \mathrm{n}-\mathrm{mk} \text { pf, } \\
1 \mathrm{n}-\mathrm{mk} \text { co }\end{array}$ & I & ve & -- & aw \\
\hline 4Bkq1b2 & $44-80$ & $7.5 \mathrm{YR} 4 / 6$ & $7.5 \mathrm{YR} 7 / 4$ & $\operatorname{lms}$ & $1-2 \mathrm{~m} \mathrm{sbk}$ & $\mathrm{h}$ & so, po & $1 \mathrm{n} \mathrm{pf}$ & II+ & ev & -- & gs \\
\hline $4 \mathrm{Bkq} 2 \mathrm{~b} 2$ & $80-125$ & 10YR 5/4 & 10YR 7/4 & $\cos$ & sg $1 \mathrm{f} \mathrm{sbk}$ & lo & so, po & $1 \mathrm{n} \mathrm{pf}$ & $\mathrm{I}+$ & es & -- & $\mathrm{cw}$ \\
\hline $4 \mathrm{Bkq} 3 \mathrm{~b} 2$ & $125-148$ & $10 \mathrm{YR} 4 / 4$ & $10 Y R 7 / 4$ & $\cos$ & $\mathrm{sg}$ & -- & so, po & N.O. & I+ & ve & -- & $\mathrm{cW}$ \\
\hline 4BCkqb2 & $148-190$ & $10 \mathrm{YR} 4 / 3$ & $10 \mathrm{YR} 6 / 3$ & $\cos$ & $\mathrm{sg}$ & lo & so, po & N.O. & $\mathrm{I}+$ & ev & -- & aw \\
\hline $5 \mathrm{Bkq} 1 \mathrm{~b} 3$ & $190-245$ & 10YR 6/4 & 10YR 7/2 & lcos & $\mathrm{m}$ & lo & so, po & N.O. & II+ & ev & -- & $\mathrm{cs}$ \\
\hline $5 \mathrm{Bkq} 2 \mathrm{~b} 3$ & $245-286+$ & $10 Y R$ 4/4 & $10 Y R 7 / 3$ & $\mathrm{~s}$ & $\mathrm{~m}$ & lo & so, po & N.O. & $\mathrm{I}+$ & ev & -- & -- \\
\hline
\end{tabular}


Table A2. So profile descriptions for Midway Valley_Continued.

\begin{tabular}{|c|c|c|c|c|c|c|c|c|c|c|c|c|}
\hline \multirow[b]{2}{*}{ Horizon } & \multirow{2}{*}{$\begin{array}{l}\text { Depth } \\
\text { (cm) }\end{array}$} & \multicolumn{2}{|c|}{ Color $^{2}$} & \multirow[b]{2}{*}{ Texture } & \multirow[b]{2}{*}{ Structure } & \multicolumn{2}{|c|}{ Consistency } & \multirow[b]{2}{*}{ Clay films } & \multirow[b]{2}{*}{$\mathrm{CaCO}_{3}{ }^{3}$} & \multirow{2}{*}{$\begin{array}{l}\mathrm{Hcl} \\
\mathrm{Rxn}\end{array}$} & \multirow{2}{*}{$\begin{array}{l}\text { Cemen- } \\
\text { tation }\end{array}$} & \multirow[b]{2}{*}{ Boundary } \\
\hline & & Moist & Dry & & & Dry & Wet & & & & & \\
\hline \multicolumn{13}{|c|}{ SOIL PIT MWV-P16 } \\
\hline Avk & $0-7$ & $10 Y R 3 / 3$ & 10YR 7/2 & 1 & $3 \mathrm{c} \mathrm{pl}$ & so-sh & ss, ps & -- & N.O. & $\mathrm{e}$ & -- & $\mathrm{cw}$ \\
\hline Bwk1 & $7-15$ & $10 Y R$ 4/4 & 10YR $7 / 3$ & fsl & $1 \mathrm{f} \mathrm{gr}$ & so & vss, vps & N.O. & $\mathrm{I}+$ & es & -- & $\mathrm{cw}$ \\
\hline Bwk2 & $15-22$ & $10 Y R$ 4/4 & 10YR 6/3 & fsl & $1 \mathrm{~m} \mathrm{pl}$ & so & vss, po & $1 \mathrm{mk} \mathrm{co}$ & I- & es & -- & as \\
\hline $\begin{array}{c}2 \mathrm{Avb} \rightarrow \\
\mathrm{Btkqb}\end{array}$ & $22-31$ & $10 \mathrm{YR} 4 / 3$ & $10 Y R 7 / 3$ & $\mathrm{msl}$ & $3 \mathrm{c} \mathrm{pl}$ & h-vh & so, po & $\begin{array}{l}1 \mathrm{n} \mathrm{pf} \\
2 \mathrm{n} \mathrm{po}\end{array}$ & I & ev & -- & aw \\
\hline 2Btkqb & $31-52$ & 7.5YR 5/6 & 5YR 6/6 & sic & $2 \mathrm{~m}-\mathrm{c} \mathrm{cpr}$ & $\mathrm{h}$ & $\mathrm{vs}, \mathrm{vp}$ & $4 \mathrm{mk}$ pf & I & ev & -- & $\mathrm{cs}$ \\
\hline 3 Btqkb & $52-72$ & $7.5 \mathrm{YR} 5 / 6$ & $7.5 \mathrm{YR} 7 / 6$ & sl & $3 \mathrm{~m}$ abk & $\mathrm{h}$ & ss, po & $2 \mathrm{n}-\mathrm{mk} \mathrm{pf}$ & I & ev & -- & aw \\
\hline $3 \mathrm{Bkq} 1 \mathrm{~b}$ & $72-155$ & $7.5 \mathrm{YR} 5 / 8$ & 7.5YR 8/4 & sl & $\mathrm{m}$ & h-vh & ss, po & N.O. & II+ & ev & -- & gs \\
\hline $3 \mathrm{Bkq} 2 \mathrm{~b}$ & $155-235$ & 10YR 6/4 & 10 YR $8 / 2$ & ls & $\mathrm{sg}$ & lo & so, po & N.O. & $\mathrm{I}+$ & ev & -- & gs \\
\hline 4Btkqb2 & $235-260+$ & 7.5YR 5/6 & $7.5 \mathrm{YR} 7 / 4$ & $\mathrm{scl}$ & $1 \mathrm{f} \mathrm{sbk}$ & sh & ss, ps & $2 \mathrm{n}$ ро & I & ev & -- & -- \\
\hline \multicolumn{13}{|c|}{ SOIL PIT MWV-P17 } \\
\hline Avk & $0-3$ & 10YR 4/4 & 10YR 6/4 & 1 & $3 \mathrm{c} \mathrm{pl}$ & $\mathrm{sh}$ & ss, ps-p & N.O. & N.O. & ve-e-es & -- & as \\
\hline $\mathrm{ABk}$ & $3-12$ & $10 Y R 5 / 4$ & 10YR 6/4 & 1 & $\mathrm{sg} 1-2 \mathrm{f}-\mathrm{m} \mathrm{pl}$ & so-sh & ss, ps & co & I & ev & -- & $\mathrm{a}-\mathrm{cs}$ \\
\hline Btk & $12-33$ & $7.5 \mathrm{YR} 6 / 6$ & 7.5YR 5/6 & sic & $2 \mathrm{f}-\mathrm{m}$ sbk & so & $\mathrm{s}, \mathrm{p}$ & $1 \mathrm{n} \mathrm{pf} \mathrm{br} \mathrm{co}$ & $\mathrm{I}+$ & ev & -- & $\mathrm{cs}$ \\
\hline 2Btkq & $33-51$ & 7.5YR 5/7 & 7.5 YR $6 / 6$ & $\mathrm{msl}$ & $1-2 \mathrm{f} \mathrm{sbk}$ & sh & ss, po & $\begin{array}{c}1 \mathrm{n} \mathrm{pf} \\
1 \mathrm{mk} \text { co }\end{array}$ & I & ev & -- & $\mathrm{a}-\mathrm{cs}$ \\
\hline $2 \mathrm{Bkq}$ & $51-77$ & $7.5 \mathrm{YR} 5 / 6$ & 7.5YR 7/6 & -- & sg $1 \mathrm{~m} \mathrm{sbk}$ & $\mathrm{h}$ & so, po & $\mathrm{v} 1 \mathrm{n} p f$ & I & e-es & -- & cs \\
\hline 2Bkqy & $77-95$ & 10YR 5/6 & 10-7.5YR 7/6 & $\operatorname{lms}$ & $1 \mathrm{~m} \mathrm{sbk} \mathrm{abk}$ & $\mathrm{h}$ & so, po & v1 n co & II & ev & -- & as \\
\hline $3 \mathrm{Bkqb}$ & $95-118$ & 10YR 5/6 & 10YR 7/6 & lfs & $\begin{array}{c}1^{\circ} \mathrm{v} 1 \mathrm{~m}-\mathrm{c} \mathrm{pl} \mathrm{sbk} \\
2^{\circ} \mathrm{v} 1 \mathrm{f} \mathrm{sbk}\end{array}$ & h-vh & so, po & $\mathrm{v} 1 \mathrm{npf}$ & II & ev & -- & $\mathrm{cs}$ \\
\hline $3 \mathrm{Bkq} 2 \mathrm{~b}$ & $118-150$ & 10YR 5/6 & $10 Y R 7 / 4$ & $\operatorname{lms}$ & mv1 f sbk & lo & so, po & N.O. & I & ev & -- & gs \\
\hline $3 \mathrm{Bkq} 3 \mathrm{~b}$ & $150-204$ & 10YR 5/4 & 10YR $7 / 3$ & lfs & $\mathrm{sg}$ & lo & so, po & N.O. & I & ev & -- & as \\
\hline 3BCkqb & $204-239+$ & $10 \mathrm{YR} 4 / 4$ & $10 Y R 7 / 3$ & lfs & $\mathrm{sg}$ & lo & so, po & N.O. & I- & ev & -- & -- \\
\hline \multicolumn{13}{|c|}{ SOIL PIT MWV-P194 } \\
\hline Avj & $0-4$ & -- & $7.5 \mathrm{YR} 6 / 2$ & s-ls & $\mathrm{sg}-1 \mathrm{~m}-\mathrm{c} \mathrm{pl}$ & so & so, po & N.O. & N.O. & eo-ve & -- & cs \\
\hline ABvk & 4-14 & -- & $7.5 \mathrm{YR} 7 / 2$ & s-ls & $\mathrm{sg}-1 \mathrm{~m} \mathrm{sbk}$ & so-sh & so, po & N.O. & I & ve-e & -- & $\mathrm{cs}$ \\
\hline $\mathrm{Bw}$ & $14-35$ & -- & 10 YR $6 / 3$ & ls-sl & $1 \mathrm{~m} \mathrm{sbk}$ & so & so, ps & v1 n po, co & N.O. & eo-ve & -- & gs \\
\hline 2Btjq & $35-55$ & -- & 7.5 YR $6 / 4$ & 1s & $1 \mathrm{~m}$ abk & $\mathrm{h}$ & so, po & $1 \mathrm{n}$ po, co & N.O. & eo-ve & -- & gw \\
\hline $3 \mathrm{Bkq} 1 \mathrm{~b}$ & 55-102 & -- & 10YR 7/4 & ls & $\mathrm{m}-1 \mathrm{~m}$ abk & $\mathrm{h}$ & so, po & N.O. & I-II & $\mathrm{e}$ & -- & ds \\
\hline $3 \mathrm{Bkq} 2 \mathrm{~b}$ & $102-163$ & -- & 10YR 7/4 & s-ls & $\mathrm{m}$ & $\mathrm{sh}$ & so, po & N.O. & I & eo-ve & -- & gw \\
\hline 4BCkqb & $163-310$ & -- & $7.5 \mathrm{YR} 7 / 4$ & $\mathrm{~s}$ & $m-s g$ & so-h & so, po & N.O. & I-II & ve-es & -- & -- \\
\hline \multicolumn{13}{|c|}{ SOIL PIT MWV-P20 } \\
\hline Avj & $0-4$ & -- & $10 Y R 6 / 3$ & ls & $\mathrm{sg}-1 \mathrm{f} \mathrm{pl}$ & lo-so & ss, po & N.O. & N.O. & eo & -- & as \\
\hline $\mathrm{ABvk}$ & $4-23$ & -- & $10 \mathrm{YR} 7 / 3$ & sl & $\begin{array}{c}1^{\circ} \mathrm{m}-1 \mathrm{~m} \mathrm{sbk} \\
2^{\circ} 1 \mathrm{~m} \mathrm{pl}\end{array}$ & so-sh & ss, po & N.O. & I+ & e-es & -- & $\mathrm{cs}$ \\
\hline
\end{tabular}




\begin{tabular}{|c|c|c|c|c|c|c|c|c|c|c|c|c|}
\hline \multirow[b]{2}{*}{ Horizon } & \multirow{2}{*}{$\begin{array}{l}\text { Depth } \\
\text { (cm) }\end{array}$} & \multicolumn{2}{|c|}{ Color ${ }^{2}$} & \multirow[b]{2}{*}{ Texture } & \multirow[b]{2}{*}{ Structure } & \multicolumn{2}{|c|}{ Consistency } & \multirow[b]{2}{*}{ Clay films } & \multirow[b]{2}{*}{$\mathrm{CaCO}_{3}{ }^{3}$} & \multirow{2}{*}{$\begin{array}{l}\mathrm{Hcl} \\
\mathrm{Rxn}\end{array}$} & \multirow{2}{*}{$\begin{array}{l}\text { Cemen- } \\
\text { tation }\end{array}$} & \multirow[b]{2}{*}{ Boundary } \\
\hline & & Moist & Dry & & & Dry & Wet & & & & & \\
\hline \multicolumn{13}{|c|}{ SOIL PIT MWV-P20 -Continued } \\
\hline 2Bwk & $23-42$ & -- & 7.5YR 6/4 & sl-1 & $1 \mathrm{vf}-\mathrm{m}$ abk & so & ss, ps & v1 n co & I- & ve & -- & gs \\
\hline 2Btkq1 & $42-85$ & -- & 7.5YR $6 / 5$ & sl-1 & $2 \mathrm{f} \mathrm{abk}$ & sh-h & ss, ps & $2 \mathrm{n} \mathrm{pf,} \mathrm{po,} \mathrm{co}$ & $\mathrm{I}+$ & es & -- & gs \\
\hline 2Btkq2 & $85-133$ & -- & 7.5YR 6/4 & ls & $\begin{array}{l}\mathrm{m}, \mathrm{sg} \\
1 \mathrm{f} \mathrm{abk}\end{array}$ & lo, h & so, po & $\ln$ co & II & es & -- & $\mathrm{cw}$ \\
\hline $3 \mathrm{Bkq}$ & $133-178$ & -- & $10 Y R 7 / 4$ & $\mathrm{~s}$ & sg & so & so, po & N.O. & I-II & es & -- & $\mathrm{cw}$ \\
\hline 4Bkqy & $178-203$ & -- & 10YR $7 / 3$ & $\mathrm{~s}$ & sg & lo & so, po & N.O. & II & es & -- & ci \\
\hline $5 \mathrm{Btkqb}$ & $203-225$ & -- & 10YR 6/4 & ls & $1 \mathrm{~m} \mathrm{sbk}$ & so, h & so, po & $2 \mathrm{nco}$ & I-II- & eo, e & -- & $\mathrm{cw}$ \\
\hline $6 \mathrm{BCkqb}$ & $225-320+$ & -- & $10 Y R 7 / 2$ & $\mathrm{~s}$ & sg & lo & so, po & N.O. & I & ev & -- & -- \\
\hline \multicolumn{13}{|c|}{ SOIL PIT MWV-P21 ${ }^{4}$} \\
\hline A1 & $0-5$ & -- & 10YR 6/3 & $\mathrm{s}$ & sg & lo & so, po & N.O. & N.O. & eo & -- & cs \\
\hline A2 & $5-35$ & -- & 10YR 6/3 & $\mathrm{s}$ & $\mathrm{sg}-1 \mathrm{f}$ sbk & so & so, po & N.O. & N.O. & eo & -- & gs \\
\hline $2 \mathrm{ACk}$ & $35-80$ & -- & 7.5YR 6/3 & $\mathrm{s}$ & $\mathrm{sg}$ & lo & so, po & N.O. & I & eo & -- & gs \\
\hline 2BCk & $80-170$ & -- & 7.5YR $6 / 3$ & $\mathrm{~s}$ & $\mathrm{sg}$ & lo & so, po & N.O. & I & $\mathrm{e}$ & -- & cs \\
\hline 3Bkqb & $170-260$ & -- & 7.5YR 8/2 & $\mathrm{s}$ & m-sg & so-sh & so, po & N.O. & II+ & es & -- & $\mathrm{cw}$ \\
\hline 4Btjkqb & $260-295$ & -- & 7.5YR 6/6 & $\mathrm{s}$ & $m-1 \mathrm{c} \mathrm{sbk}$ & sh-h & so, po & $2 \mathrm{nco}$ & I & eo, e & -- & gw \\
\hline $5 \mathrm{Bkqb}$ & $295-345+$ & -- & 7.5 YR $8 / 3$ & $\mathrm{~s}$ & $\mathrm{~m}$ & sh-h & so, po & N.O. & II+ & ev & -- & -- \\
\hline \multicolumn{13}{|c|}{ SOIL PIT MWV-P22 } \\
\hline Avk & $0-10$ & 10YR 4/4 & $10 \mathrm{YR} 6 / 2$ & 1 & $3 \mathrm{vc} \mathrm{pl}$ & sh & ss & N.O. & N.O. & es & -- & aw \\
\hline 2Btjk & $10-32$ & $10 \mathrm{YR} 4 / 4$ & $10 Y R 7 / 2$ & $\mathrm{scl}$ & $2 \mathrm{f}-\mathrm{m} \mathrm{sbk}$ & so & ss, ps-p & v1 n pf, co & N.O. & ve-e & -- & aw \\
\hline 2Btkq & $32-63$ & $10 Y R$ 5/4 & 10YR 7/6 & $\operatorname{lmcos}$ & $3 \mathrm{f}-\mathrm{m}$ sbk & h-vh & so, po & $\begin{array}{c}1 \mathrm{n} \mathrm{pf}, \\
2 \mathrm{n}-\mathrm{mk} \text { po }\end{array}$ & I & ve & -- & $\mathrm{cw}$ \\
\hline 2Bkq1 & $63-80$ & 10YR 4/4 & $10 Y R$ 6/4 & lmcos-sl & $1-2 \mathrm{f} \mathrm{sbk}$ & sh-h & so, po & N.O. & I+-II & es-ev & -- & $\mathrm{cw}$ \\
\hline 2Bkq2 & 80-130 & 10YR 4/4 & $10 Y R 7 / 4$ & mcos-ls & $\mathrm{m}$ & sh-h & so, po & N.O. & I- & ve & -- & $\mathrm{cW}$ \\
\hline $2 \mathrm{Ckq}$ & $130-260+$ & 10YR 4/4 & 10YR 7/3 & $\cos$ & $\mathrm{sg}$ & lo & so, po & N.O. & N.O. & eo & -- & -- \\
\hline \multicolumn{13}{|c|}{ SOIL PIT MWV-P23 } \\
\hline Avk & $0-10$ & $10 Y R 4 / 3$ & $10 Y R 7 / 3$ & sicl & $3 \mathrm{c} \mathrm{pl}$ & sh-h & ss-s, ps & N.O. & N.O. & ve-e & -- & as \\
\hline 2Btkq & $10-30$ & $10 \mathrm{YR} 4 / 6$ & $10 Y R 6 / 4$ & sl & $2 \mathrm{f}-\mathrm{m} \mathrm{sbk}$ & so-sh & ss, ps & $2 \mathrm{n} \mathrm{pf,} \mathrm{po}$ & I & ve-e & -- & aw \\
\hline 2Btkqm & $30-68$ & 7.5YR 5/6 & 10YR 7/6 & $\operatorname{lcos}$ & $1 \mathrm{c} \mathrm{pl}$ & $\mathrm{h}$ & so, po & $2 \mathrm{n} \mathrm{pf}$ & I & ve & $\mathrm{cs}$ & $\mathrm{cw}$ \\
\hline $2 \mathrm{Kqm}$ & $68-135$ & $7.5 \mathrm{YR} 5 / 6$ & $10 Y R 7 / 3$ & $\operatorname{lcos}$ & $\mathrm{m}$ & sh-h & so, po & N.O. & III+ & ev & cs & $\mathrm{cw}$ \\
\hline $2 \mathrm{Kq}$ & $135-175$ & 10YR 6/3 & $10 \mathrm{YR} 8 / 2$ & $\cos$ & $\mathrm{m}$ & $\mathrm{sh}$ & so, po & N.O. & III & ev & -- & $\mathrm{cw}$ \\
\hline $\mathrm{Bkq}$ & $175-195$ & 10YR 5/4 & 10YR $8 / 2$ & $\cos$ & $\mathrm{m}$ & sh-h & so, po & N.O. & $\mathrm{II}+$ & e-es & -- & aw \\
\hline $2 \mathrm{Ck}$ & $195-300+$ & 10YR 5/4 & 10YR $7 / 2$ & $\cos$ & sg & lo & so, po & N.O. & I- & $\mathrm{e}$ & -- & -- \\
\hline
\end{tabular}


Table A2. So profile descriptions for Midway Valley_Continued.

\begin{tabular}{|c|c|c|c|c|c|c|c|c|c|c|c|c|}
\hline \multirow[b]{2}{*}{ Horizon } & \multirow{2}{*}{$\begin{array}{l}\text { Depth } \\
(\mathrm{cm})\end{array}$} & \multicolumn{2}{|c|}{ Color $^{2}$} & \multirow[b]{2}{*}{ Texture } & \multirow[b]{2}{*}{ Structure } & \multicolumn{2}{|c|}{ Consistency } & \multirow[b]{2}{*}{ Clay films } & \multirow[b]{2}{*}{$\mathrm{CaCO}_{3}{ }^{3}$} & \multirow{2}{*}{$\begin{array}{l}\mathrm{Hcl} \\
\mathrm{Rxn}\end{array}$} & \multirow{2}{*}{$\begin{array}{l}\text { Cemen- } \\
\text { tation }\end{array}$} & \multirow[b]{2}{*}{ Boundary } \\
\hline & & Moist & Dry & & & Dry & Wet & & & & & \\
\hline \multicolumn{13}{|c|}{ SOIL PIT MWV-P24 } \\
\hline $\operatorname{Av}(k ?)$ & $0-8$ & 10YR 5/4 & $10 Y R 7 / 3$ & fscl & $3 \mathrm{vc} \mathrm{pl}$ & $\mathrm{sh}$ & $\mathrm{s}, \mathrm{p}$ & N.O. & N.O. & $\mathrm{e}$ & -- & as \\
\hline Btk & $8-25$ & $10 Y R 5 / 4$ & 10YR 6/3.5 & fscl & $2 \mathrm{f}-\mathrm{m}$ sbk & so-sh & $\mathrm{s}, \mathrm{p}$ & $\begin{array}{l}1 \mathrm{n} \mathrm{pf} \\
1 \mathrm{n} \mathrm{po}\end{array}$ & N.O. & ve & -- & aw \\
\hline $2 \mathrm{Btkq}$ & $25-48$ & 10YR 4/6 & 7.5YR 6/4 & $\mathrm{mscl}$ & $\begin{array}{c}1^{\circ} 3 \mathrm{f} \mathrm{sbk} \\
2^{\circ} 1 \mathrm{f}-\mathrm{m} \mathrm{pl}\end{array}$ & $\mathrm{vh}$ & ss-s, ps-p & $\begin{array}{c}2 \mathrm{n}-\mathrm{mk} \text { pf } \\
1 \mathrm{n} \text { po }\end{array}$ & I & $\mathrm{e}$ & -- & $\mathrm{cw}$ \\
\hline 2Btkq2 & $48-83$ & 7.5YR 5.5/6 & 7.5YR 6/6 & $\cos 1$ & $\begin{array}{c}1^{\circ} 3 \mathrm{~m} \mathrm{sbk} \\
2^{\circ} 1 \mathrm{~m} \mathrm{pl}\end{array}$ & vh-eh & ss, ps & $\begin{array}{c}2-3 \text { n-mk pf, po, } \\
3 \text { n co }\end{array}$ & I & e-es & -- & $\mathrm{a}-\mathrm{cw}$ \\
\hline 2Bkq1 & 83-132 & 10YR 5/6 & 10YR 7/4 & ls & $\mathrm{m}$ & $\mathrm{h}$ & so, po & N.O. & II & ev & -- & $\mathrm{cw}$ \\
\hline $2 \mathrm{Bkq} 2$ & $132-197$ & $10 \mathrm{YR} 4 / 3$ & $10 \mathrm{YR} 7 / 3$ & $\cos$ & sg-m & lo-so & so, po & N.O. & I & es & -- & gs \\
\hline $2 \mathrm{Cq}$ & $197-247$ & 10YR 3.5/4 & 10YR 7/4 & $\cos$ & sg & lo & so, po & N.O. & N.O. & eo & -- & vaw \\
\hline $3 \mathrm{Bkqb}$ & $247-287+$ & 10YR 7/6 & 10YR 8/4 & $\cos$ & $1 \mathrm{~m} \mathrm{pl}$ & $\mathrm{vh}$ & so, po & N.O. & II & ev & -- & -- \\
\hline \multicolumn{13}{|c|}{ SOIL PIT MWV-P25 } \\
\hline Avk & $0-10$ & $10 Y R 4 / 3$ & $10 Y R 7 / 3$ & fscl & $2 \mathrm{c} \mathrm{pl}$ & sh & $\mathrm{s}, \mathrm{p}$ & N.O. & N.O. & ve & -- & as \\
\hline 2Btkj & $10-32$ & 7.5YR 4/6 & 7.5YR 6/4 & fscl & $1 \mathrm{f}-\mathrm{m} \mathrm{gr}$ & so & ss, p & $\mathrm{v} 1 \mathrm{n} \mathrm{pf}$ & I- & ve & -- & ci \\
\hline $3 \mathrm{Bkq}$ & $32-50$ & 10YR 6/4 & 7.5 YR $8 / 2$ & lcos & $1 \mathrm{f}-\mathrm{m} \mathrm{pl}$ & $\mathrm{vh}$ & so, po & N.O. & II-III & es & -- & $a b$ \\
\hline 3Kqym & $50-65$ & 7.5YR 7/2 & $7.5 \mathrm{YR} 8 / 2$ & sl & $\mathrm{m}-1 \mathrm{cpl}$ & eh & so, po & N.O. & IV & ev & $\mathrm{cs}$ & $\mathrm{cw}$ \\
\hline 3Кqy & $65-100$ & 10YR 7/4 & $10 Y R \quad 8 / 3$ & lcos & $\mathrm{m}$ & $\mathrm{h}$ & so, po & N.O. & IV & ev & -- & as \\
\hline 3Bkq1 & $100-136$ & 10YR 5/2 & 10YR 8/2 & $\cos$ & sg & lo & so, po & N.O. & II+-III & ev & -- & $\mathrm{cw}$ \\
\hline $3 \mathrm{Bkq} 2$ & $136-198$ & $10 \mathrm{YR} 4 / 2$ & $10 \mathrm{YR} 7 / 2$ & $\cos$ & sg & lo & so, po & N.O. & I-II+ & ev & -- & aw \\
\hline $4 \mathrm{Bkq}$ & $198-245$ & $7.5 Y R \quad 4 / 4$ & $7.5 \mathrm{YR} 8 / 6$ & $\cos$ & $\mathrm{m}-\mathrm{sg}$ & sh & so, po & N.O. & I+-II & ev & -- & $\mathrm{cW}$ \\
\hline $4 \mathrm{Ckq} 1$ & $245-290$ & $7.5 Y R \quad 4 / 4$ & 7.5 YR $7 / 4$ & $\cos$ & $\mathrm{m}$ & so & so, po & N.O. & N.O. & ve & -- & $\mathrm{cW}$ \\
\hline $4 \mathrm{Ckq} 2$ & $290-320+$ & $10 Y R 4 / 3$ & 10YR 8/3 & $\cos$ & $\mathrm{m}$ & lo & so, po & N.O. & N.O. & ve & -- & -- \\
\hline \multicolumn{13}{|c|}{ SOIL PIT MWV-P26 } \\
\hline Avkq & $0-7$ & $10 Y R$ 4/4 & $10 Y R 7 / 3$ & fscl & $3 \mathrm{c} \mathrm{pl}$ & sh & ss, p & N.O. & N.O. & ve-e & -- & as \\
\hline $\mathrm{Bw}$ & $7-18$ & 7.5 YR $4 / 6$ & $7.5 Y R 7 / 4$ & fscl & $2 \mathrm{f}-\mathrm{m} \mathrm{gr}$ & so & ss-s, p & N.O. & N.O. & eo & -- & $\mathrm{cw}$ \\
\hline 2Btjq & $18-33$ & $5 \mathrm{YR} 4 / 6$ & $5 Y R 7 / 4$ & 1 & $2 \mathrm{f}-\mathrm{m} \mathrm{gr}$ & sh & ss, p & $\mathrm{v} 1 \mathrm{n} p f$ & N.O. & eo & -- & as \\
\hline $\begin{array}{l}2 \mathrm{Avkqmb} \rightarrow \\
2 \mathrm{Bwkqmb}\end{array}$ & $33-45$ & $7.5 Y R 3 / 4$ & $7.5 Y R 6 / 4$ & sl-1 & $3 \mathrm{c} \mathrm{pl}$ & $\mathrm{vh}$ & so, po & N.O. & I & $\mathrm{e}$ & cs & as \\
\hline 2Btkqb & $45-53$ & 7.5YR 5/6 & 7.5YR 7/4 & $\mathrm{scl}$ & $3 \mathrm{f} \mathrm{abk}$ & $\mathrm{h}$ & ss, p & $2 \mathrm{npf}$ & I+ & e-es & -- & aw \\
\hline $2 \mathrm{Btqb}$ & $53-83$ & 5YR 5/6 & 5YR 5/6 & $\mathrm{scl}$ & $3 \mathrm{f}-\mathrm{m} \mathrm{gr}$ & sh & $\mathrm{s}, \mathrm{p}$ & $3 \mathrm{n}-\mathrm{mk}$ pf & N.O. & eo-ve & -- & $a-c w$ \\
\hline 3Кqymb & $83-123$ & 10YR 6/6 & 10YR 8/3 & $\cos l$ & $\mathrm{~m}$ & vh & so, po & N.O. & III+ & es & cs & $\mathrm{cw}$ \\
\hline 3Bkqyb & $123-147$ & 7.5YR 4/4 & 7.5YR 7/4 & ls & sg-m & sh & so, po & N.O. & I+-II & es & -- & $\mathrm{cw}$ \\
\hline 3BCkqb & $147-195$ & 7.5YR 4/6 & 7.5YR 6/4 & 1s & sg & lo & so, po & N.O. & I- & $\mathrm{e}$ & & $\mathrm{cw}$ \\
\hline $3 \mathrm{Ckqb}$ & $195-270+$ & $10 \mathrm{YR} 4 / 3$ & $10 \mathrm{YR} 7 / 3$ & $\cos$ & sg-m & lo & so, po & N.O. & N.O. & ve & -- & -- \\
\hline
\end{tabular}




\begin{tabular}{|c|c|c|c|c|c|c|c|c|c|c|c|c|}
\hline \multirow[b]{2}{*}{ Horizon } & \multirow{2}{*}{$\begin{array}{l}\text { Depth } \\
\text { (cm) }\end{array}$} & \multicolumn{2}{|c|}{ Color $^{2}$} & \multirow[b]{2}{*}{ Texture } & \multirow[b]{2}{*}{ Structure } & \multicolumn{2}{|c|}{ Consistency } & \multirow[b]{2}{*}{ Clay films } & \multirow[b]{2}{*}{$\mathrm{CaCO}_{3}^{3}$} & \multirow{2}{*}{$\begin{array}{l}\mathrm{Hcl} \\
\mathrm{Rxn}\end{array}$} & \multirow{2}{*}{$\begin{array}{l}\text { Cemen- } \\
\text { tation }\end{array}$} & \multirow[b]{2}{*}{ Boundary } \\
\hline & & Moist & Dry & & & Dry & Wet & & & & & \\
\hline \multicolumn{13}{|c|}{ SOIL PIT MWV-P28 } \\
\hline Avk & $0-8$ & $10 Y R$ 4/4 & $10 Y R 7 / 3$ & $\mathrm{cl}-1$ & $3 \mathrm{c} \mathrm{pl}$ & sh & ss, p & N.O. & N.O. & $\mathrm{e}$ & -- & aw \\
\hline BAtq & $8-13$ & $10 \mathrm{YR} 4 / 4$ & $10 \mathrm{YR} 6 / 3$ & $\mathrm{cl}$ & $1 \mathrm{f} \mathrm{pl}$ & sh & ss-s, p & $\begin{array}{l}2 \text { n-mk pf, } \\
2 \text { n-mk po }\end{array}$ & N.O. & eo-ve & -- & $\mathrm{cs}$ \\
\hline Btq & $13-26$ & 10-7.5YR 4/6 & 7.5YR 6/4 & $\mathrm{scl}$ & $3 \mathrm{f}-\mathrm{m}$ abk & $\mathrm{h}$ & $\mathrm{s}, \mathrm{p}$ & $\begin{array}{l}3 \mathrm{mk} \text { pf, } \\
3 \mathrm{mk} \text { po }\end{array}$ & I & eo & -- & cs \\
\hline 2Btkq & $26-43$ & 10YR 4/4 & 10YR 6/4 & $\mathrm{scl}$ & $\begin{array}{c}1^{\circ} 3 \mathrm{f}-\mathrm{m} \mathrm{abk} \\
2^{\circ} \mathrm{v} 1 \mathrm{f} \mathrm{pl}\end{array}$ & $\mathrm{h}$ & $\begin{array}{r}\text { ss-s, p } \\
3\end{array}$ & $\begin{array}{r}3 \text { n-mk pf, } \\
\text { n-mk po }\end{array}$ & I & ve-e & -- & gs \\
\hline 2Btkq2 & $43-66$ & 7.5YR 4/6 & 7.5YR 7/6 & sic & $\begin{array}{c}1^{\circ} 1-2 \mathrm{~m} \mathrm{pl} \\
2^{\circ} 3 \mathrm{fabk}\end{array}$ & $\mathrm{h}$ & $\mathrm{s}, \mathrm{p}_{3}$ & $\begin{array}{c}3 \text { n-mk pf, } \\
\text { mk po }\end{array}$ & I & ev & -- & cs \\
\hline 3Btkqb & $66-91$ & 10-7.5YR 5/4 & 7.5YR 7/4 & $\mathrm{scl}$ & $\begin{array}{c}1^{\circ} 1 \mathrm{~m} \mathrm{pl} \\
2^{\circ} 2 \mathrm{f}-\mathrm{m} \mathrm{sbk}\end{array}$ & sh & ss-s, ps & $2 \mathrm{n} \mathrm{pf}$ & II & ev & -- & aw \\
\hline 3BKqmb & $91-130$ & 10YR 6/4 & $10 Y R$ 8/4 & ls & $2 \mathrm{~m} \mathrm{pl}$ & vh & so, po & N.O. & III+ & es & --* & $\mathrm{cw}$ \\
\hline 3Bkqb & $130-182$ & 10YR 7/4 & $10 Y R \quad 8 / 3$ & ls & $1 \mathrm{~m} \mathrm{pl}$ & $\mathrm{h}$ & so, po & N.O. & $\mathrm{II}+$ & ev & -- & $\mathrm{cs}$ \\
\hline 3BCkqb & $182-208$ & 10YR 4.5/4 & $10 Y R 7 / 3$ & $\mathrm{~ms}$ & $\mathrm{sg}$ & lo & so, po & N.O. & I & es & -- & aw \\
\hline $3 \mathrm{Ckqb}$ & $208-246$ & 10YR 4/4 & 10YR 7/3 & $\mathrm{ms}$ & sg & lo & so, po & N.O. & I- & eo-ve & -- & aw \\
\hline $4 \mathrm{Bqb} 2$ & $246-287$ & 10YR 4.5/6 & 7.5YR 7/6 & lfms & $2 \mathrm{f} \mathrm{abk}$ & $\mathrm{h}$ & so, po & $\mathrm{v} 1 \mathrm{npf}$ & N.O. & eo & -- & gs \\
\hline $4 \mathrm{Bkqb} 2$ & $287-345+$ & 10YR 6/3 & $10 Y R$ 8/3 & lfs & $\mathrm{m}$ & $\mathrm{h}$ & so, po & N.O. & II & ev & -- & -- \\
\hline \multicolumn{13}{|c|}{ SOIL PIT MWV-P37 } \\
\hline $\mathrm{Cu}$ & $0-50+$ & 10YR 7/6 & $10 Y R 5 / 4$ & $\mathrm{~s}$ & sg & lo & so, po & N.O. & N.O. & ve & -- & -- \\
\hline \multicolumn{13}{|c|}{ SOIL PIT MWV-P38 } \\
\hline A & $0-1$ & $10 \mathrm{YR} 4 / 3$ & $10 \mathrm{YR} 6 / 3$ & sl & $1 \mathrm{f} \mathrm{pl}$ & so & so, po & N.O. & N.O. & ve & -- & as \\
\hline $\mathrm{CBw}$ & $1-10$ & $10 Y R 4 / 3$ & 10YR 6/4 & ls-sl & $\mathrm{v} 1 \mathrm{vf} g r$ & lo & so, po & N.O. & N.O. & eo & -- & cs \\
\hline $\mathrm{Ck}$ & $10-30$ & $10 \mathrm{YR} 5 / 3$ & $10 Y R 6 / 4$ & ls-sl & $\mathrm{sg}$ & lo & so, po & N.O. & N.O. & $\mathrm{e}$ & -- & $\mathrm{cW}$ \\
\hline $2 \mathrm{Bkb}$ & $30-50+$ & 10YR 5/4 & 10YR 7/4 & sl & $\mathrm{m}$ & so & so, po & N.O. & I & es & -- & -- \\
\hline \multicolumn{13}{|c|}{ SOIL PIT MWV-P39 } \\
\hline $\mathrm{C}$ & $0-40+$ & $10 Y R 4 / 3$ & $10 Y R$ 6/3-4 & $\mathrm{ms}$ & $\mathrm{sg}$ & lo & so, po & N.O. & N.O. & ve & -- & -- \\
\hline \multicolumn{13}{|c|}{ SOIL PIT MWV-P40 } \\
\hline A & $0-4$ & $10 Y R 4 / 4$ & $10 Y R$ 6/4 & $\mathrm{s}$ & $1 \mathrm{f} \mathrm{gr}$ & lo-so & so, po & N.O. & N.O. & -- & -- & $\mathrm{a}-\mathrm{cs}$ \\
\hline $2 \operatorname{Cox}$ & $4-14$ & 10YR 5/4 & 10YR 7/4 & lfs & $1 \mathrm{f} \mathrm{gr}$ & so & so, vps & N.O. & N.O. & -- & -- & $\mathrm{cw}$ \\
\hline $3 \mathrm{C}$ & $14-30$ & 10YR 5/4 & 10YR 6/4 & $\operatorname{lms}$ & $\mathrm{sg}$ & lo & so, po & N.O. & N.O. & -- & -- & $\mathrm{cw}$ \\
\hline $3 \mathrm{BCk}$ & $30-50+$ & 10YR 5/4 & 10YR 6/4 & $1 \mathrm{~ms}$ & $\mathrm{sg}$ & lo & so, po & N.O. & I- & -- & -- & -- \\
\hline
\end{tabular}


Table A2. So profile descriptions for Midway Valley_Continued.

\begin{tabular}{|c|c|c|c|c|c|c|c|c|c|c|c|c|}
\hline \multirow[b]{2}{*}{ Horizon } & \multirow{2}{*}{$\begin{array}{l}\text { Depth } \\
\text { (cm) }\end{array}$} & \multicolumn{2}{|c|}{ Color $^{2}$} & \multirow[b]{2}{*}{ Texture } & \multirow[b]{2}{*}{ Structure } & \multicolumn{2}{|c|}{ Consistency } & \multirow[b]{2}{*}{ Clay films } & \multirow[b]{2}{*}{$\mathrm{CaCO}_{3}{ }^{3}$} & \multirow{2}{*}{$\begin{array}{l}\mathrm{Hcl} \\
\mathrm{Rxn}\end{array}$} & \multirow{2}{*}{$\begin{array}{l}\text { Cemen- } \\
\text { tation }\end{array}$} & \multirow[b]{2}{*}{ Boundary } \\
\hline & & Moist & Dry & & & Dry & Wet & & & & & \\
\hline \multicolumn{13}{|c|}{ SOIL PIT NRSF-TP16 } \\
\hline Av & $0-10$ & 10YR 4/4 & 10YR 6/4 & lfs & $3 \mathrm{vc} \mathrm{pl}$ & lo-so & so, po & N.O. & N.O. & ve, es & -- & as \\
\hline $2 \mathrm{Btj}$ & $10-13$ & 8.25 YR $4 / 4$ & $10 Y R$ 6/3 & fsl & $1 \mathrm{vf} g r$ & -- & ss, ps & vf n pf, po & N.O. & eo & -- & $\mathrm{cw}$ \\
\hline $2 \mathrm{Bwk}$ & $13-28$ & $7.5 \mathrm{YR} 4 / 4$ & $7.5 Y R \quad 4 / 4$ & fsl & $\mathrm{m}$ & $\mathrm{sh}$ & ss, ps & N.O. & N.O. & eo, ve-e & -- & $a b$ \\
\hline $3 \mathrm{Avb}$ & $28-37$ & $10 Y R 4 / 4$ & $10 Y R$ 6/2 & fsl & $3 \mathrm{vc} \mathrm{abk}$ & $\mathrm{vh}$ & ss, ps & N.O. & N.O. & ve & -- & $a b$ \\
\hline 4Btqk1b & $37-67$ & 7.5YR 4/6 & 7.5 YR $6 / 6$ & fsl & $3 \mathrm{f}-\mathrm{m}$ abk & sh-h & ss, ps & 2 n-mk pf, po & I & ve & -- & gw \\
\hline $4 \mathrm{Btqk} 2 \mathrm{~b}$ & $67-95$ & 7.5YR 4/6 & 7.5 YR $6 / 6$ & ls & $3 \mathrm{f}-\mathrm{m}$ abk & -- & -- & $1 \mathrm{n} \mathrm{pf}$ & I+ & -- & -- & aw \\
\hline $4 \mathrm{Kqmb}$ & $95-115$ & $10 \mathrm{YR} 6 / 3$ & 10 YR $7 / 2$ & $1 \cos$ & $2 \mathrm{f}-\mathrm{m} \mathrm{pl}$ & $\mathrm{vh}$ & so, po & N.O. & III-IV & ev & $\mathrm{cw}$ & aw \\
\hline 4Bkqb & $115-133$ & 10YR 4/4 & 10YR 6/3 & lcos & $1 \mathrm{~m} \mathrm{sbk}$ & h-vh & so, po & N.O. & I+ & $\mathrm{e}$ & -- & $\mathrm{cw}$ \\
\hline $5 \mathrm{Btqb} 2 \mathrm{k}$ & $133-161$ & $10 Y R$ 5/4 & $10 Y R 7 / 4$ & l-sil & $3 \mathrm{f}-\mathrm{m} \mathrm{abk}$ & sh & $\mathrm{s}, \mathrm{p}$ & $1 \mathrm{n} \mathrm{pf}$ & I+ & es & -- & $\mathrm{cw}$ \\
\hline $6 \mathrm{Btqb} 2 \mathrm{k}$ & $161-175$ & $10 Y R \quad 4 / 6$ & $10 \mathrm{YR} 6 / 4$ & sl-1 & $1-2 \mathrm{f}-\mathrm{m} \mathrm{sbk}$ & sh-h & ss, ps & $\mathrm{vf} \mathrm{n} p f$ & N.O. & es & -- & aw \\
\hline $6 \mathrm{Kqb} 2$ & $175-217$ & 10YR 6/4 & $10 Y R$ 8/2 & $\cos l$ & $1-2 \mathrm{f} \mathrm{pl}$ & h-vh & so, po & N.O. & IV & ev & -- & $\mathrm{cw}$ \\
\hline $6 \mathrm{Bkqb} 2$ & $217-275+$ & 10YR 5/4 & 10YR 6/4 & sl & $1 \mathrm{~m} \mathrm{pl}$ & so-sh & so, po & N.O. & II & ev & -- & -- \\
\hline \multicolumn{13}{|c|}{ SOIL PIT NRSF-TP18 } \\
\hline Av & $0-8$ & $10 Y R$ 4/4 & 10YR $5.5 / 3$ & lfs & -- & so-sh & so, po & N.O. & N.O. & eo & -- & cs \\
\hline Bwk & $8-34$ & 10YR 5/4 & -- & sl & $1 \mathrm{~m} \mathrm{sbk-abk}$ & -- & -- & N.O. & I- & ve-e & -- & gs \\
\hline $\mathrm{Ck}$ & $34-56$ & $10 Y R$ 5/4 & -- & sl & $\mathrm{m}$ & -- & so, ps & N.O. & N.O. & ve & -- & aw-i \\
\hline 2Btkqmb & $56-78$ & $7.5 \mathrm{YR} 4 / 6$ & -- & sl & -- & -- & -- & 2n-mk pf, po & I & ve, e & $\mathrm{cw}$ & aw \\
\hline $2 \mathrm{Kqm} 1 \mathrm{~b}$ & $78-90$ & -- & $10 \mathrm{YR} 8 / 2$ & lcos & $1-2 \mathrm{~m} \mathrm{pl}$ & eh & so, po & N.O. & IV & ev & $--*$ & aw \\
\hline $2 \mathrm{Kqm} 2 \mathrm{~b}$ & $90-100$ & 10YR 6/4 & 10YR 7/4 & lcos & $\mathrm{m}$ & $\mathrm{vh}$ & so, po & N.O. & II & ev & $--*$ & gw \\
\hline $2 \mathrm{Ckqb}$ & $100-163$ & 7.5YR 5/6 & 7.5YR 6.5/4 & -- & $\mathrm{m}$ & $\mathrm{sh}$ & -- & N.O. & $\mathrm{I}+$ & ve, ev & -- & aw \\
\hline $3 \mathrm{Ckb}$ & $163-273+$ & 10YR 6/5 & 10YR 7/3 & lcos & $\mathrm{m}$ & sh-h & so, po & N.O. & -- & ev & -- & -- \\
\hline \multicolumn{13}{|c|}{ TRENCH MWV-T5-3 to $5 \mathrm{~m}$} \\
\hline Ap & $0-3$ & $10 Y R$ 4/4 & 10YR 7/3 & $\mathrm{scl}$ & $1 \mathrm{f}-\mathrm{m}$ sbk & vfr & ss-s, p & N.O. & N.O. & -- & -- & $\mathrm{cw}$ \\
\hline Btk & $3-25$ & 7.5YR 5/6 & $10-7.5$ YR $7 / 4$ & $\mathrm{scl}$ & $1-2 \mathrm{f}-\mathrm{m} \mathrm{sbk}$ & fi & ss-s, p & $\begin{array}{c}1^{\circ} 2 \mathrm{n}-\mathrm{mk} \text { pf } \\
2^{\circ} 2 \mathrm{n} \mathrm{po}\end{array}$ & I & -- & -- & cs-w \\
\hline 2Btkqm & $25-106$ & $10 Y R$ 5/6 & 7.5YR 7/4 & ls & $\mathrm{m}$ & vfi & so, po & $2 \mathrm{mk}$ co & II-III & -- & $--*$ & aw \\
\hline $\begin{array}{l}\text { 3Bkqm/ } \\
\mathrm{Kqm}\end{array}$ & $106-130$ & $10 \mathrm{YR} 8 / 2$ & 10YR 8/1 & ls & $\mathrm{m}$ & efi & so, po & N.O. & III & -- & --* & $a-c w$ \\
\hline 3Bk & $130-184$ & 10YR 5/4 & 10YR 7/4 & ls & sg & lo & so, ps & N.O. & II & -- & -- & $a-c w$ \\
\hline 4Btkq & $150-190^{5}$ & 10YR 4/6 & 10YR 5/4 & sl & $3 \mathrm{f}-\mathrm{m}$ sbk & $\mathrm{h}$ & ss, po & ln pf & $\mathrm{I}+$ & -- & -- & $\mathrm{cW}$ \\
\hline $4 \mathrm{Bkqb}$ & $190-220$ & 10YR 5/4 & 10YR 6/6 & ls & $\begin{array}{c}1^{\circ} 1 \mathrm{fgr} \\
2^{\circ} \mathrm{sg}\end{array}$ & lo-so & so, po & $1 \mathrm{n} \mathrm{pf}$ & $\mathrm{I}+$ & -- & -- & $\mathrm{cw}$ \\
\hline $4 \mathrm{Bkq} 2 \mathrm{~b}$ & $220-260$ & 10YR 5/4 & 10YR 7/4 & ls & $\mathrm{m}$ & $\mathrm{sh}$ & so, po & N.O. & II & -- & -- & $\mathrm{cs}$ \\
\hline $4 \mathrm{Bkb}$ & $260-290$ & 10YR 5/4 & 10YR 7/4 & ls & $\mathrm{sg}$ & lo & so, po & N.O. & II & -- & -- & $\mathrm{cw}$ \\
\hline $4 \mathrm{Ckb}$ & $290-350+$ & 10 YR $5 / 8$ & -- & $\mathrm{s}$ & $\mathrm{sg}$ & lo & so, po & N.O. & I & -- & -- & -- \\
\hline
\end{tabular}




\begin{tabular}{|c|c|c|c|c|c|c|c|c|c|c|c|c|}
\hline \multirow[b]{2}{*}{ Horizon } & \multirow{2}{*}{$\begin{array}{l}\text { Depth } \\
(\mathrm{cm})\end{array}$} & \multicolumn{2}{|c|}{ Color ${ }^{2}$} & \multirow[b]{2}{*}{ Texture } & \multirow[b]{2}{*}{ Structure } & \multicolumn{2}{|c|}{ Consistency } & \multirow[b]{2}{*}{ Clay films } & \multirow[b]{2}{*}{$\mathrm{CaCO}_{3}{ }^{3}$} & \multirow{2}{*}{$\begin{array}{l}\mathrm{Hcl} \\
\mathrm{Rxn}\end{array}$} & \multirow{2}{*}{$\begin{array}{l}\text { Cemen- } \\
\text { tation }\end{array}$} & \multirow[b]{2}{*}{ Boundary } \\
\hline & & Moist & Dry & & & Dry & Wet & & & & & \\
\hline \multicolumn{13}{|c|}{ TRENCH MWV-T5-44 m } \\
\hline$(\mathrm{A}+\mathrm{B}) \mathrm{p}$ & $0-13$ & 10YR 4/4 & -- & $\mathrm{scl}$ & $1 \mathrm{f} \mathrm{pl}$ & $\mathrm{fr}$ & $\mathrm{s}, \mathrm{p}$ & 1n po & N.O. & ve & -- & $\mathrm{cs}$ \\
\hline Bk & $13-39$ & 10YR 5/4 & -- & $\mathrm{scl}$ & $1 \mathrm{c} \mathrm{sbk}$ & fr & $\mathrm{s}, \mathrm{p}$ & 1n po & I- & ve & -- & $\mathrm{a}-\mathrm{cw}$ \\
\hline 2Btkq & $39-86$ & 7.5YR 6/6 & -- & $\mathrm{scl}$ & $2 \mathrm{~m}-\mathrm{c} \mathrm{sbk}$ & $\mathrm{fr}$ & $\mathrm{s}, \mathrm{p}$ & $\begin{array}{l}1^{\circ} 2 \mathrm{n}-\mathrm{mk} \text { pf } \\
2^{\circ} 3 \mathrm{n}-\mathrm{mk} \text { po }\end{array}$ & I & ve-e & -- & aw \\
\hline $3 \mathrm{Bkqb}$ & $86-95$ & 7.5YR 5/6 & -- & sl & $2 \mathrm{f}-\mathrm{m} \mathrm{sbk}$ & fr-fi & so, po & 2n-mk pf & I & e-es & -- & $\mathrm{cw}$ \\
\hline $3 \mathrm{Bkq} 2 \mathrm{~b}$ & $95-115$ & 10YR 6/6 & -- & sl & $2 \mathrm{~m} \mathrm{gr}$ & fi & so, po & N.O. & II+ & es-ev & -- & $\mathrm{cw}$ \\
\hline $3 \mathrm{Bkq} 3 \mathrm{~b}$ & $115-173$ & 10YR 6/4 & 10YR 8/3 & sl & $\mathrm{m}$ & $\mathrm{h}$ & so, po & N.O. & II + & es & -- & gw \\
\hline $3 \mathrm{Bkq} 4 \mathrm{~b}$ & $173-203$ & $10 \mathrm{YR} 4 / 4$ & $10 \mathrm{YR} 8 / 3$ & $\mathrm{~s}$ & $\begin{array}{l}1^{\circ} \mathrm{m} \\
2^{\circ} \mathrm{sg}\end{array}$ & lo & so, po & N.O. & II- & $\mathrm{e}$ & -- & aw \\
\hline $4 \mathrm{Bkqb} 2$ & $203-214$ & 7.5YR 5/6 & 7.5YR 8/4 & sl & $1 \mathrm{f} \mathrm{gr}$ & so-sh & ss, po & N.O. & $\mathrm{I}+$ & $\mathrm{e}$ & -- & $\mathrm{a}-\mathrm{cw}$ \\
\hline 4Bkq2b2 & $214-255$ & 7.5YR 4/6 & 10YR 5/8 & ls & $3 \mathrm{f}-\mathrm{m}$ sbk & $\mathrm{h}$ & so, po & $\ln \mathrm{pf}$ & I & ve-e & -- & $\mathrm{cW}$ \\
\hline 4Bkq3b2 & $255-300$ & 7.5YR 4/4 & 7.5YR 5/6 & ls & $2 \mathrm{~m} \mathrm{sbk}$ & vfi & so, po & N.O. & $\mathrm{I}$ & eo & -- & $\mathrm{cw}$ \\
\hline 4Ckqb2 & $300-335+$ & 7.5YR 4/6 & 7.5YR 7/4 & ls & sg & lo & so, po & N.O. & $\mathrm{I}-$ & -- & -- & -- \\
\hline \multicolumn{13}{|c|}{ TRENCH MWV-T5-185 m } \\
\hline A & $0-9$ & 10YR 5-6/3 & 10YR 3-4/3 & sl & $1 \mathrm{fgr}$ & lo-so & vss, ps & N.O. & N.O. & eo & -- & cs \\
\hline 2Bwk & $9-35$ & 10YR 5/4 & 10YR 6/3 & sl & $\begin{array}{c}1^{\circ} 1 \mathrm{~m}-\mathrm{c} \mathrm{sbk} \\
2^{\circ} \mathrm{m}\end{array}$ & so & vss, ps & N.O. & I & ve & -- & $\mathrm{cw}$ \\
\hline $2 \mathrm{Bk}$ & $35-58$ & 10YR 5/4 & 10YR 7/4 & sl & sg & lo & vss, ps & N.O. & I & e-es & -- & aw \\
\hline 3Btkqb & $58-88^{6}$ & 7.5 YR 5/6 & $7.5 Y R 7 / 4$ & sl & $3 \mathrm{~m}-\mathrm{c}$ sbk & $\mathrm{h}$ & ss, ps & $2 \mathrm{npf}$ & I & $\mathrm{e}$ & -- & $\mathrm{a}$ \\
\hline $4 \mathrm{Bkqb} 2$ & 88-121 & 10YR 6/4 & 10YR 8/3 & ls & $2 \mathrm{~m} \mathrm{pl}$ & h-vh & so, po & N.O. & II-II+ & $\mathrm{e}$ & -- & $\mathrm{a}-\mathrm{cs}$ \\
\hline 4Btjkqb2 & $121-153$ & 10YR 5/6 & 10YR 6/4 & ls & $1 \mathrm{f}-\mathrm{m} \mathrm{sbk}$ & $\mathrm{vh}$ & so, po & vfn pf & I & ve-e & -- & aw \\
\hline 5Btjkqb3 & $153-193$ & $10 Y R$ 4/4 & 10YR 6-7/4 & ls & 2-3 sbk & $\mathrm{h}$ & so, po & 1n-mk pf & I & eo-ve & -- & $\mathrm{cw}$ \\
\hline $5 \mathrm{Bkqb3}$ & $193-223$ & 10YR 5/4 & 10YR 7/4 & ls & $1 \mathrm{~m} \mathrm{sbk}$ & sh-h & so, po & N.O. & I & $\mathrm{e}$ & -- & $\mathrm{a}-\mathrm{cw}$ \\
\hline $5 \mathrm{CBkb} 3$ & $223-273$ & 10YR 6/4 & $10 \mathrm{YR} 7 / 3$ & ls & $\begin{array}{c}1^{\circ} \mathrm{v} 1 \mathrm{f} \mathrm{gr} \\
2^{\circ} \mathrm{m}\end{array}$ & so & so, po & N.O. & I+ & es-ev & -- & aw-i \\
\hline 6Btjkqb4 & $273-318+$ & 10-7.5YR 5-6/4 & 10-7.5YR 7/4 & sl & $3 \mathrm{~m} \mathrm{sbk}$ & $\mathrm{h}$ & so-vss, po-vps & vfn pf & I & eo-ve & -- & -- \\
\hline \multicolumn{13}{|c|}{ TRENCH MWV-T5-272 m } \\
\hline Avp & $0-7$ & 10YR 6/4 & $10 \mathrm{YR} 8 / 3$ & sl-1 & $3 \mathrm{c} \mathrm{pl}$ & sh & ss, ps-p & N.O. & N.O. & ve & -- & $a b$ \\
\hline $\begin{array}{c}2 \mathrm{Bwk} \\
(2 \mathrm{Btjk} ?)\end{array}$ & $7-20$ & 10YR 5/4 & $10 \mathrm{YR} 7 / 3$ & 1 & $2 \mathrm{mgr}$ & so & $\mathrm{s}, \mathrm{p}$ & vfn po & I & es & -- & aw \\
\hline $3 \mathrm{Avbkq}$ & $20-25$ & 10YR 5-6/4 & $10 \mathrm{YR} 8 / 2$ & sl & $3 \mathrm{c} \mathrm{pl}$ & $\mathrm{vh}$ & ss, ps & vfn po & $\mathrm{I}-$ & ve-e & -- & $a w-b$ \\
\hline $3 \mathrm{Btkqb}$ & $25-45$ & 7.5YR 5/4-6 & 7.5YR 6/4 & sl & $\begin{array}{c}1^{\circ} 3 \mathrm{vf}-\mathrm{f} \mathrm{abk} \\
2^{\circ} 1 \mathrm{f} \mathrm{pl}\end{array}$ & $\mathrm{h}$ & ss, ps & $\begin{array}{l}1^{\circ} 4 \mathrm{mk}-\mathrm{k} \text { pf } \\
2^{\circ} 4 \mathrm{mk}-\mathrm{k} \text { po }\end{array}$ & I- & eo-ve & -- & $\mathrm{cw}$ \\
\hline 4Btkq2b & $45-85$ & 7.5YR 6/6 & 7.5YR 6/4-6 & sicl & $\begin{array}{c}1^{\circ} 3 \mathrm{f}-\mathrm{m} \mathrm{abk} \\
2^{\circ} 1 \mathrm{f} \mathrm{pr}\end{array}$ & sh & $\mathrm{s}, \mathrm{p}$ & $\begin{array}{c}1^{\circ} 4 \mathrm{mk}-\mathrm{k} \text { pf } \\
2^{\circ} 4 \mathrm{mk}-\mathrm{k} \text { po }\end{array}$ & $\mathrm{I}+$ & es & -- & $\mathrm{cw}$ \\
\hline $4 \mathrm{Btkq} 3 \mathrm{~b}$ & $85-100$ & 7.5YR 6/6 & 7.5YR 6-7/4 & sicl & $2 \mathrm{f} \mathrm{sbk}$ & sh-h & $\mathrm{s}, \mathrm{p}$ & vfn-mk pf & $\mathrm{I}-$ & ve-e & -- & aw \\
\hline
\end{tabular}


Table A2. So profile descriptions for Midway Valley_Continued.

\begin{tabular}{|c|c|c|c|c|c|c|c|c|c|c|c|c|}
\hline \multirow[b]{2}{*}{ Horizon } & \multirow{2}{*}{$\begin{array}{l}\text { Depth } \\
\text { (cm) }\end{array}$} & \multicolumn{2}{|c|}{ Color ${ }^{2}$} & \multirow[b]{2}{*}{ Texture } & \multirow[b]{2}{*}{ Structure } & \multicolumn{2}{|c|}{ Consistency } & \multirow[b]{2}{*}{ Clay films } & \multirow[b]{2}{*}{$\mathrm{CaCO}_{3}{ }^{3}$} & \multirow{2}{*}{$\begin{array}{l}\mathrm{Hcl} \\
\mathrm{Rxn}\end{array}$} & \multirow{2}{*}{$\begin{array}{l}\text { Cemen- } \\
\text { tation }\end{array}$} & \multirow[b]{2}{*}{ Boundary } \\
\hline & & Moist & Dry & & & Dry & Wet & & & & & \\
\hline \multicolumn{13}{|c|}{ TRENCH MWV-T5-272 m-Continued } \\
\hline $\begin{array}{c}5 \mathrm{Bkqb} 2 \\
(5 \mathrm{Kqb} 2 ?)\end{array}$ & $100-134$ & 10YR 7/4 & 10YR 8/1 & ls & $\begin{array}{c}1^{\circ} 1 \mathrm{f} \mathrm{pl} \\
2^{\circ} \mathrm{m}\end{array}$ & vh & so, po & N.O. & III+ & ev & -- & $\mathrm{a}-\mathrm{cw}$ \\
\hline 6Btjkqb3 & $134-146$ & 10YR 6/3-4 & $10 Y R$ 8/3 & ls & $2 \mathrm{f}-\mathrm{m} \mathrm{sbk}$ & $\mathrm{h}$ & ss, po & $\begin{array}{c}1^{\circ} \mathrm{fn} \mathrm{pf} \\
2^{\circ} \text { vfn po }\end{array}$ & II & $\mathrm{e}$ & -- & $\mathrm{cw}$ \\
\hline 6Bkqb3 & $146-175$ & $10 Y R 6 / 3$ & 10YR 7/3 & ls & $\begin{array}{c}1^{\circ} 1 \mathrm{fgr} \\
2^{\circ} \mathrm{m}\end{array}$ & so-sh & so, po & N.O. & II+ & es-ev & -- & as \\
\hline 7Btjkqb4 & $175-185$ & 10-7.5YR 5/4 & 10-7.5YR 6/4 & sl & $2 \mathrm{f} \mathrm{sbk}$ & sh & ss, ps & $\begin{array}{l}1^{\circ} \text { vfn pf } \\
2^{\circ} \text { vfn po }\end{array}$ & I & eo\&e & -- & $\mathrm{a}-\mathrm{cw}$ \\
\hline 8Btjkqb4 & $185-212$ & 10-7.5YR 5/6 & $10-7.5$ YR $7 / 4$ & sl & $2 \mathrm{f}-\mathrm{m} \mathrm{gr}$ & $\mathrm{h}$ & vss, ps & $\begin{array}{c}1^{\circ} \mathrm{f}-2 \mathrm{n} \mathrm{pf} \\
2^{\circ} \mathrm{fn} \text { po }\end{array}$ & I- & ve-e & -- & $\mathrm{cW}$ \\
\hline 8Btjkq2b4 & $212-226$ & 10-7.5YR 5/4 & 10-7.5YR 7/4 & ls & $2 \mathrm{f}-\mathrm{m} \mathrm{sbk}$ & sh-h & so, po & $\begin{array}{c}1^{\circ} \mathrm{fn} \text { br } \\
2^{\circ} \text { vfn po }\end{array}$ & I- & ve-e & -- & $\mathrm{a}-\mathrm{cw}$ \\
\hline 8Bkqb4 & $226-249$ & $10 Y R 7 / 3$ & 10YR 8/3 & ls & $1 \mathrm{~m} \mathrm{sbk}$ & $\mathrm{h}$ & so, po & vfn pf & II & e-es & -- & $\mathrm{cW}$ \\
\hline 8Bkq2b4 & 249-304 & 10YR 6/4 & 10YR 7-8/3 & ls & $\begin{array}{c}1^{\circ} 1 \mathrm{fgr} \\
2^{\circ} \mathrm{m}\end{array}$ & h-vh & so, po & vfn pf & II+ & es & -- & aw \\
\hline 9Btqb5 & $304-320+$ & 7.5YR 4/6 & 10-7.5YR 7/4 & ls-sl & $3 \mathrm{f}-\mathrm{m}$ sbk & sh-h & so, ps & $\begin{array}{l}1^{\circ} 2-3 \mathrm{n} \mathrm{pf} \\
2^{\circ} 3 \mathrm{mk} \mathrm{co}\end{array}$ & N.O. & eo & -- & -- \\
\hline
\end{tabular}

\begin{tabular}{|c|c|c|c|c|c|c|c|c|c|c|c|c|}
\hline \multicolumn{13}{|c|}{ TRENCH MWV-T5-306 m } \\
\hline Av & $0-8$ & $10-7.5$ YR 5/4 & 10YR 7/4 & 1 & $3 \mathrm{c} \mathrm{pl}$ & so-sh & ss, ps & N.O. & N.O. & eo & -- & as \\
\hline $2 \mathrm{Bw}$ & $8-30$ & 10-7.5YR 5/4 & $10 Y R$ 6/4 & 1 & $2 \mathrm{~m} \mathrm{sbk}$ & so & ss, ps & N.O. & I & ve & -- & aw \\
\hline 3Btkqb & $30-56$ & $5-7.5$ YR 5/6 & 5-7.5YR 6/6 & sicl & $3 \mathrm{f}$ abk & so & $\mathrm{s}, \mathrm{p}$ & $\begin{array}{c}1^{\circ} 2 \mathrm{n}-\mathrm{mk} \text { pf } \\
2^{\circ} 2 \mathrm{n} \mathrm{co}\end{array}$ & I- & $\mathrm{e}$ & -- & aw \\
\hline 4Btkqb2 & $56-70$ & 7.5YR 6/4 & 7.5YR 7/4 & sl & $\begin{array}{c}1^{\circ} 1 \mathrm{c} \mathrm{pl} \\
2^{\circ} 1 \mathrm{~m} \mathrm{sbk}\end{array}$ & h-vh & ss, ps & $\begin{array}{l}1^{\circ} 2-3 n \text { pf } \\
\circ^{\circ} 2-3 n \text { po, co }\end{array}$ & I & es & -- & $\mathrm{cw}$ \\
\hline $\begin{array}{c}\text { 4Bkqb2/ } \\
\text { Kqb2 }\end{array}$ & $70-106$ & 10YR 6/4 & 10YR 8/2 & ls & $2 \mathrm{~m} \mathrm{pl}$ & vh & so, po & N.O. & III-IV & es & -- & $\mathrm{a}-\mathrm{cw}$ \\
\hline 5Btjkqb3 & $105-135$ & 7.5YR 5/6 & 7.5YR 7/4 & sl & $2-3 \mathrm{~m} \mathrm{sbk}$ & $\mathrm{h}$ & vss, vps & $\begin{array}{l}1^{\circ} \text { vfn pf } \\
2^{\circ} \text { vfn co }\end{array}$ & I & ve & -- & cs \\
\hline $5 \mathrm{Bkqb3}$ & $135-173$ & 10YR 6/3 & 10YR 8/3 & ls & $\mathrm{m}$ & sh-h & so, po & N.O. & II & -- & -- & aw \\
\hline $6 \mathrm{Kqmb} 4$ & $173-310+$ & 10YR 8/2 & 10YR 8/1 & ls & $\mathrm{m}$ & eh & so, po & N.O. & IV & ev & -- & -- \\
\hline \multicolumn{13}{|c|}{ TRENCH A/BR-3-18.5m } \\
\hline Ap & $0-8$ & 10YR 4/4 & 10YR 6/3 & fsl & $2 \mathrm{~m}-\mathrm{c} \mathrm{pl}$ & sh & ss, ps & N.O. & N.O. & N.O. & -- & aw \\
\hline $2 \mathrm{AB}$ & $8-25$ & $10 Y R 4 / 4$ & 10YR 6.5/3 & fsl & $2 \mathrm{f}-\mathrm{m}$ gr & $\mathrm{sh}$ & ss, ps & N.O. & N.O. (d) & ve & -- & $\mathrm{cw}$ \\
\hline $2 \mathrm{Bw}$ & $25-35$ & $7.5 Y R$ 4/6 & 7.5YR 6.5/4 & fsl & $2 \mathrm{~m} \mathrm{gr}$ & $\mathrm{sh}$ & ss, ps & N.O. & N.O. & N.O. & -- & aw \\
\hline 2Btkq & $35-55$ & $7.5 Y R \quad 4 / 6$ & 7.5YR 5/5 & $\mathrm{scl}$ & $3 c$ gr $3 f$ gr & $\mathrm{sh}$ & $\mathrm{s}, \mathrm{p}$ & $3 \mathrm{mk}$ pf & I+ & ev & -- & va-aw \\
\hline $3 \mathrm{Kqm} 1 \mathrm{~b}$ & $55-78$ & $10 \mathrm{YR} 7 / 2.5$ & 10YR $8 / 2.5$ & $\operatorname{lcos}$ & $3 \mathrm{c}-\mathrm{vc} \mathrm{pl}$ & eh & so, po & N.O. & IV & ev & cs & aw \\
\hline
\end{tabular}




\begin{tabular}{|c|c|c|c|c|c|c|c|c|c|c|c|c|}
\hline \multirow[b]{2}{*}{ Horizon } & \multirow{2}{*}{$\begin{array}{l}\text { Depth } \\
\text { (cm) }\end{array}$} & \multicolumn{2}{|c|}{ Color ${ }^{2}$} & \multirow[b]{2}{*}{ Texture } & \multirow[b]{2}{*}{ Structure } & \multicolumn{2}{|c|}{ Consistency } & \multirow[b]{2}{*}{ Clay films } & \multirow[b]{2}{*}{$\mathrm{CaCO}_{3}{ }^{3}$} & \multirow{2}{*}{$\begin{array}{l}\mathrm{Hcl} \\
\mathrm{Rxn}\end{array}$} & \multirow{2}{*}{$\begin{array}{l}\text { Cemen- } \\
\text { tation }\end{array}$} & \multirow[b]{2}{*}{ Boundary } \\
\hline & & Moist & Dry & & & Dry & Wet & & & & & \\
\hline \multicolumn{13}{|c|}{ TRENCH A/BR-3-18.5m—Continued } \\
\hline $3 \mathrm{Kqm} 2 \mathrm{~b}$ & $78-105$ & 10YR $7 / 2.5$ & 10YR $8 / 2.5$ & $\operatorname{lcos}$ & $1 \mathrm{c} \mathrm{pl}$ & eh & so, po & N.O. & III-IV & ev & cs & cs \\
\hline 3Bkqmb & $105-141$ & $10 \mathrm{YR} 5 / 3$ & $10 \mathrm{YR} 8 / 3$ & $\operatorname{lcos}$ & $\mathrm{m}$ & $\mathrm{h}$ & so, po & N.O. & II+ & ev & $\mathrm{cw}$ & $\mathrm{cw}$ \\
\hline $3 \mathrm{Ck} 1 \mathrm{~b}$ & $141-175$ & $10 \mathrm{YR} 5 / 3$ & $10 \mathrm{YR} 8 / 3$ & $\mathrm{~s}$ & sg-m & so & so, po & N.O. & I & ev & -- & $\mathrm{cw}$ \\
\hline $3 \mathrm{Ck} 2 \mathrm{~b}$ & $175-195$ & $10 Y R 5 / 3$ & $10 Y R 8 / 3$ & $\mathrm{~s}$ & sg-m & so & so, po & N.O. & $\mathrm{I}+$ & ev & -- & as \\
\hline $4 \mathrm{Cb}$ & $195-237$ & $10 Y R 5 / 3$ & $10 \mathrm{YR} 8 / 3$ & $\mathrm{~s}$ & sg-m & so & so, po & N.O. & N.O. & ev & -- & as \\
\hline $5 \mathrm{Cb}$ & $237-242+$ & $10 Y R 5 / 3$ & $10 Y R$ 8/3 & $\mathrm{s}$ & sg-m & so & so, po & N.O. & N.O. & ev & -- & \\
\hline \multicolumn{13}{|c|}{ TRENCH A/BR-3-105m } \\
\hline Ap & $0-10$ & $10 \mathrm{YR} 4 / 4$ & $10 \mathrm{YR} 6 / 3$ & fsl & lc gr & sh & ss,ps-p & N.O. & N.O.(d) & ve & - & as \\
\hline $2 \mathrm{AB}$ & $10-25$ & 10YR 4/4 & 10YR 6/3 & fsl & If $\mathrm{gr}$ & so & ss,ps & N.O. & N.O. & N.O. & - & aw \\
\hline $2 \mathrm{Bw}$ & $25-36$ & 7.5YR 4/4 & 7.5YR 6/4 & fsl & lf gr & lo-so & ss,ps-p & N.O. & N.O.(d) & $\mathrm{e}$ & - & aw \\
\hline 2Bwk & $36-73$ & 7.5YR 4/4 & 7.5YR 6/4 & fsl & $2 \mathrm{~m}-\mathrm{c} \mathrm{gr}$ & sh-h & ss,ps-p & N.O. & N.O.(d) & e & - & $a b$ \\
\hline 3Btkqb & $73-75$ & 7.5YR 4/5 & 7.5YR 5/5 & $\mathrm{scl}$ & $3 \mathrm{~m} \mathrm{gr}$ & $\mathrm{h}$ & ss,ps & $1-2 \mathrm{n} \mathrm{pf}$ & I & $\mathrm{e}$ & - & va-ab \\
\hline 4Bkqymb2 & $75-121$ & 10YR 5/4 & $10 Y R 7 / 3$ & $\operatorname{lcos}$ & lc pl & $\mathrm{h}$ & so,po & N.O. & II+-II & ev & $\mathrm{cw}$ & aw \\
\hline 4Bkqylb2 & $121-143$ & 10YR 5/4 & 10YR $7 / 3$ & $\operatorname{lcos}$ & sg-m & $\mathrm{sh}$ & so,po & N.O. & II & ev & - & $\mathrm{cw}$ \\
\hline 4Bkqy2b2 & $143-202$ & 10YR 5/4 & 10YR 7/3 & lcos & $\mathrm{m}$ & $\mathrm{sh}$ & so,po & N.O. & II & ev & - & $\mathrm{cw}$ \\
\hline 4Ckb2 & $202-265+$ & 10YR 4/3.5 & 10YR $6.5 / 3$ & $\operatorname{lcos}$ & $\mathrm{sg}$ & lo & so,po & N.O. & $\mathrm{I}+$ & ev & - & - \\
\hline \multicolumn{13}{|c|}{ TRENCH MWV-T4-2m } \\
\hline A & $0-7$ & 7.5YR 4/4 & 7.5YR 5/4 & $\mathrm{scl}$ & $1 \mathrm{vf-f} g r$ & so & ss-s, ps-p & N.O. & N.O. & ve & -- & $\mathrm{cs}$ \\
\hline Btj & $7-20$ & $10 Y R 4 / 3$ & 10YR 6/3 & fsl & $2 \mathrm{~m} \mathrm{sbk}$ & so & ss, ps & vl n po & N.O. & eo & -- & aw \\
\hline 2Btqb & $20-63$ & 7.5YR 4/6 & 7.5YR 5/6 & $\mathrm{scl}$ & $\begin{array}{c}1^{\circ} 3 \mathrm{~m}-\mathrm{c} \mathrm{sbk} \\
2^{\circ} 1 \mathrm{~m}-\mathrm{c} \mathrm{c}\end{array}$ & $\mathrm{h}$ & s-vs, p & 3 n-mk pf & N.O. & eo & $\mathrm{cw}$ & $\mathrm{cw}$ \\
\hline 2Btkb & $63-73$ & 7.5YR 4/4 & 7.5YR 6/6 & $\mathrm{scl}$ & $1 \mathrm{f}-\mathrm{m} \mathrm{sbk}$ & so-sh & $\mathrm{ss}, \mathrm{ps}$ & $1-2 \mathrm{npf}$ & I & $\mathrm{e}$ & -- & as \\
\hline $3 \mathrm{Kqmb} 2$ & $73-123$ & 7.5YR 7/6 & 7.5YR 8/4 & sl & $2 \mathrm{~m} \mathrm{pl}$ & vh & so, po & N.O. & IV & ev & cs & -- \\
\hline 3Bkqmb2 & $123-160$ & 7.5YR 6/4 & 7.5YR 7/4 & sl & 1f $\mathrm{pl}$ & sh-h & so, po & N.O. & II+ & ev & cs & aw \\
\hline Rk & $160+$ & Tertiar & volcanic bedroc & exposed i & base of trench & condary & rbonate-sili & fills fracture & & & & \\
\hline \multicolumn{13}{|c|}{ TRENCH MWV-T4-4m } \\
\hline Ap & $0-4$ & 10YR 4/4 & $10 \mathrm{YR} 6 / 4$ & fsl & $1-2 \mathrm{~m} \mathrm{sbk}$ & so & so, ps & N.O. & N.O. & eo & -- & as \\
\hline BAt & $4-10$ & 10YR 4/4-6 & 10YR 6/4 & $\mathrm{scl}$ & $2 \mathrm{~m} \mathrm{sbk}$ & $\mathrm{fr}^{* *}$ & $\mathrm{~s}, \mathrm{p}$ & $\begin{array}{c}1^{\circ} 1 \mathrm{npo} \\
2^{\circ} \mathrm{vl} \mathrm{n} \mathrm{pf}\end{array}$ & N.O. & eo & -- & cs \\
\hline Btkq & $10-40$ & 7.5YR 6/4 & 10-7.5YR 6/4 & $\mathrm{scl}$ & $3 \mathrm{~m} \mathrm{sbk}$ & $\mathrm{h}$ & ss-s, p & $1^{\circ} 2 \mathrm{npf}$ & I & eo & -- & as \\
\hline $\mathrm{Bq}$ & $40-93$ & 7.5YR 5/6 & 7.5YR 6/8 & sl & $1 \mathrm{~m} \mathrm{sbk}$ & sh & vss, vps & -- & N.O. & eo & -- & $\mathrm{g}$ \\
\hline CBqk & $93-114$ & 10YR 5/6 & 10YR $7 / 4$ & ls & $\begin{array}{c}1^{\circ} \mathrm{m} \\
1 \mathrm{f} \mathrm{sbk}\end{array}$ & lo-so & so, po & N.O. & N.O. & ve & -- & $--^{-7}$ \\
\hline $2 \mathrm{Bkgb}$ & $114-134$ & 7.5YR 5/6 & -- & ls & 1 for & $\mathrm{fr} * *$ & vss, po & $1 \mathrm{n} \mathrm{co}$ & $\mathrm{I}+$ & e & -- & aw \\
\hline
\end{tabular}


Table A2. So profile descriptions for Midway Valley—Continued.

\begin{tabular}{|c|c|c|c|c|c|c|c|c|c|c|c|c|}
\hline \multirow[b]{2}{*}{ Horizon } & \multirow{2}{*}{$\begin{array}{l}\text { Depth } \\
\text { (cm) }\end{array}$} & \multicolumn{2}{|c|}{ Color $^{2}$} & \multirow[b]{2}{*}{ Texture } & \multirow[b]{2}{*}{ Structure } & \multicolumn{2}{|c|}{ Consistency } & \multirow[b]{2}{*}{ Clay films } & \multirow[b]{2}{*}{$\mathrm{CaCO}_{3}{ }^{3}$} & \multirow{2}{*}{$\begin{array}{l}\mathrm{Hcl} \\
\mathrm{Rxn}\end{array}$} & \multirow{2}{*}{$\begin{array}{l}\text { Cemen- } \\
\text { tation }\end{array}$} & \multirow[b]{2}{*}{ Boundary } \\
\hline & & Moist & Dry & & & Dry & Wet & & & & & \\
\hline \multicolumn{13}{|c|}{ TRENCH MWV-T4-4m-Continued } \\
\hline $3 \mathrm{Bkb}$ & $134-153$ & $7.5 \mathrm{YR} 4 / 6$ & $7.5 \mathrm{YR} 7 / 4$ & fsl & $1 \mathrm{~m} \mathrm{sbk}$ & fr & ss, ps & N.O. & I & eo & -- & $\mathrm{cw}$ \\
\hline $4 \mathrm{CBkb}$ & $153-186$ & $10 Y R 4 / 4$ & $10 Y R 7 / 4$ & fs & $\mathrm{m}$ & so & so, po & N.O. & $\mathrm{I}+$ & ve-e & -- & cs \\
\hline
\end{tabular}

${ }^{1}$ Locations of soil pits and trenches shown in figures 1,2, and A1.

${ }^{2}$ From Munsell soil color chart (Munsell Color Company, 1988); -- , no data.

${ }^{3}$ Calcium carbonate, stages I, II, III, and IV are defined in Birkeland (1984) and Birkeland and others (1991); N.O., none observed; d, disseminated in matrix..

${ }^{4}$ Profile described by Scott Lundstrom (U.S. Geological Survey, written commun., 1994).

${ }^{5}$ The soil profile from the surface down to the boundary between the 3Bk and 4Btkq was described at station $3 \mathrm{~m}$, and the lower profile below this boundary was described at station $5 \mathrm{~m}$. The depth to the boundary between $3 \mathrm{Bk}$ and $4 \mathrm{Btkq}$ is at $184 \mathrm{~cm}$ at station $3 \mathrm{~m}$ and $150 \mathrm{~cm}$ at station $5 \mathrm{~m}$.

${ }^{6}$ The profile from the surface to a depth of $58 \mathrm{~cm}$ was described on the north wall of the trench because of disturbance (backhoe) of the south wall. The profile below $58 \mathrm{~cm}$ was described on the south wall.

${ }^{7}$ Moved description of profile from station $4 \mathrm{~m}$ to station $6 \mathrm{~m}$ along the soil horizon boundary.

\section{Description Abbreviations}

\section{Master horizon:}

A-surface horizon characterized by accumulation of organic matter and typically as a zone of illuviation of clay, sesquioxides, silica, gypsum, carbonate, and/or salts; B-subsurface horizon characterized by a redder color, stronger structure development, and/or accumulation of secondary illuvial materials (clay, sesquioxide, silica, gypsum, and salts); C-subsurface horizon that may appear similar or dissimilar to the parent material and includes unaltered material and material in various stages of weathering; K-subsurface horizon engulfed with carbonate to the extent that its morphology is determined by the carbonate.

\section{Master horizon modifiers:}

b-buried soil horizon; j-used in conjunction with other modifiers to denote incipient development of that particular feature or property; k-accumulation of carbonates; m-strong cementation; ox-oxidized (for C horizon only); p-plowing or other disturbance; q-accumulation of silica; t-accumulation of clay; u-soil properties undifferentiated; v-vesicular structure; w-color or structural B horizon; y-accumulation of gypsum. Numbers within unit descriptions: prefix numbers refer to differentiated horizons with increasing depth in soil profile; numbers within or following unit designation refer to further differentiation of properties within an individual soil.

\section{Texture:}

sl-sand loam; fsl-fine sandy loam; msl-medium sandy loam; cosl-coarse sandy loam; ls-loamy sand; lfs-loamy fine sand; lms-loamy medium sand; lcos-loamy coarse sand; s-sand; fs-fine sand; ms-medium sand; cos-coarse sand; 1-loam; cl-clay loam; scl-sandy clay loam; fscl-fine sandy clay loam; mscl-medium sandy clay loam; sil-silt loam; sicl-silty clay loam; c-clay; sic-silty clay; -- no data.

\section{Structure:}

$1^{\circ}$-primary; $2^{\circ}$-secondary; m-massive; sg-single grain; 1-weak; v1-very weak; 2-moderate; 3 -strong; f-fine; m-medium; c-coarse; vc-very coarse; pl-platy; gr-granular; abk-angular blocky; sbk-subangular blocky; cpr-columnar; pr-prismatic;

\section{Consistency:}

Dry: h-hard; sh-slightly hard; vh-very hard; eh-extremely hard; lo-loose; so-soft; vfr-very friable (moist); fi-firm (moist); vfi-very firm (moist); efi-extremely firm (moist). Wet: sononsticky; vss-very slightly sticky; ss-slightly sticky; s-sticky; vs-very sticky; po-nonplastic; vps-very slightly plastic; ps-slightly plastic; p-plast; c; vp-very plastic 


\section{Description Abbreviations-Continued}

\section{Clay films:}

$1^{\circ}$-primary; $2^{\circ}$-secondary; f-few; vf-very few; 2-common; 3-many; 4-continuous; $n$-thin; mk-moderately thick; br-clay bridges holding mineral grains together; pf-faces of peds; po-lining or filling tabular or interstitial pores; co-colloidal stains on mineral grains; N.O.-none observed

Reaction to cold, dilute hydrochloric acid (HCI Rxn):

eo-none observed; ve-very slight; e-slight; es-strong; ev-violent

Cementation:

--* no data; -- not cemented, but secondary carbonate and silica may be present; cs-weak; cs-strong Boundary (with lower horizon):

va-very abrupt; a-abrupt; c-clear; g-gradual; d-diffuse; s-smooth; w-wavy; i-irregular; b-broken 

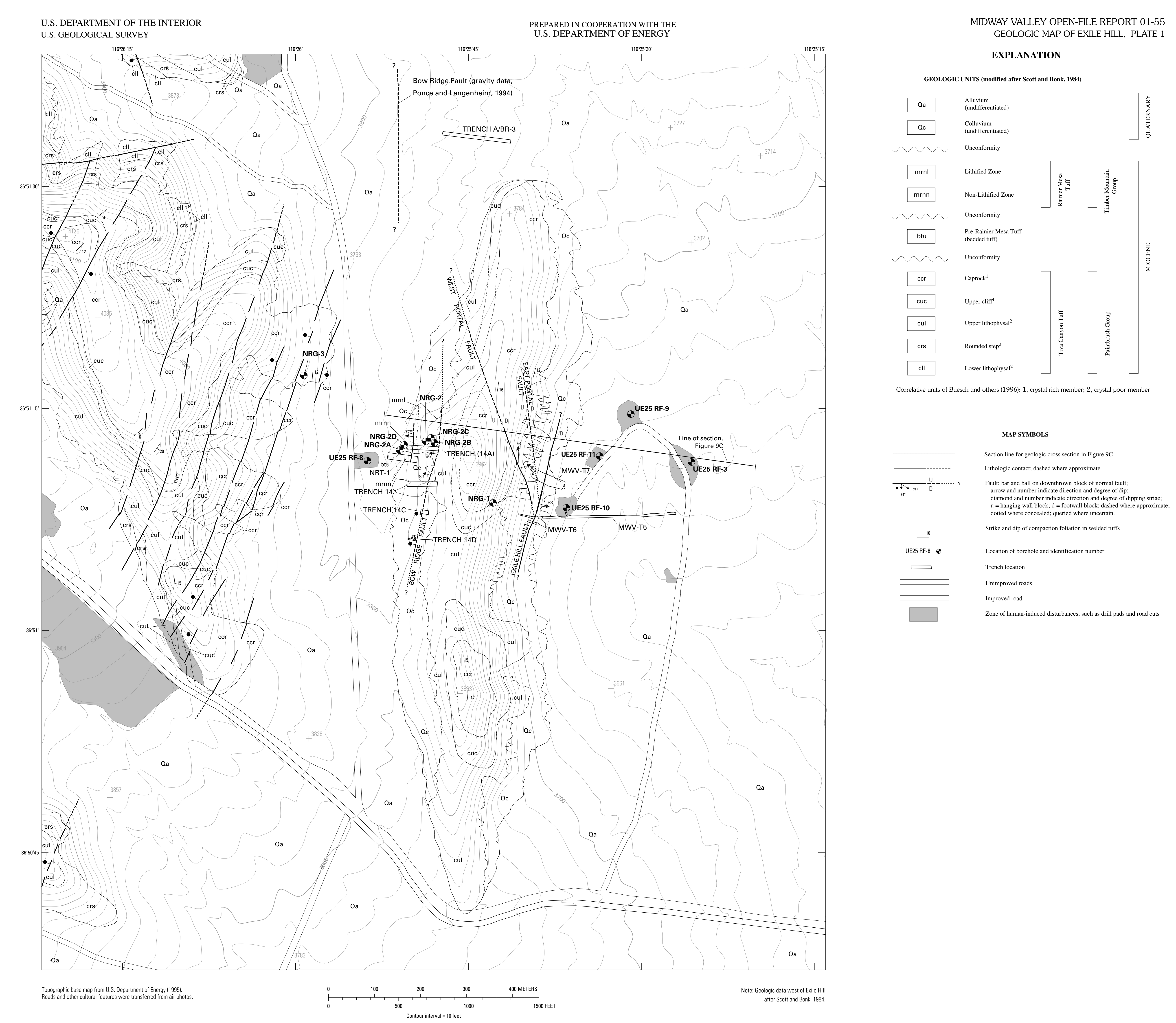

GEOLOGIC MAP OF THE EXILE HILL AREA, WESTERN MIDWAY VALLEY AND EASTERN YUCCA MOUNTAIN, NEVADA.

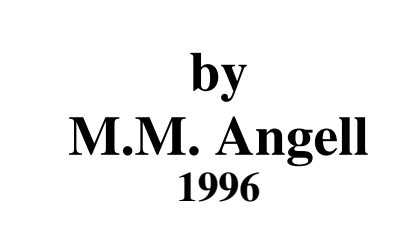




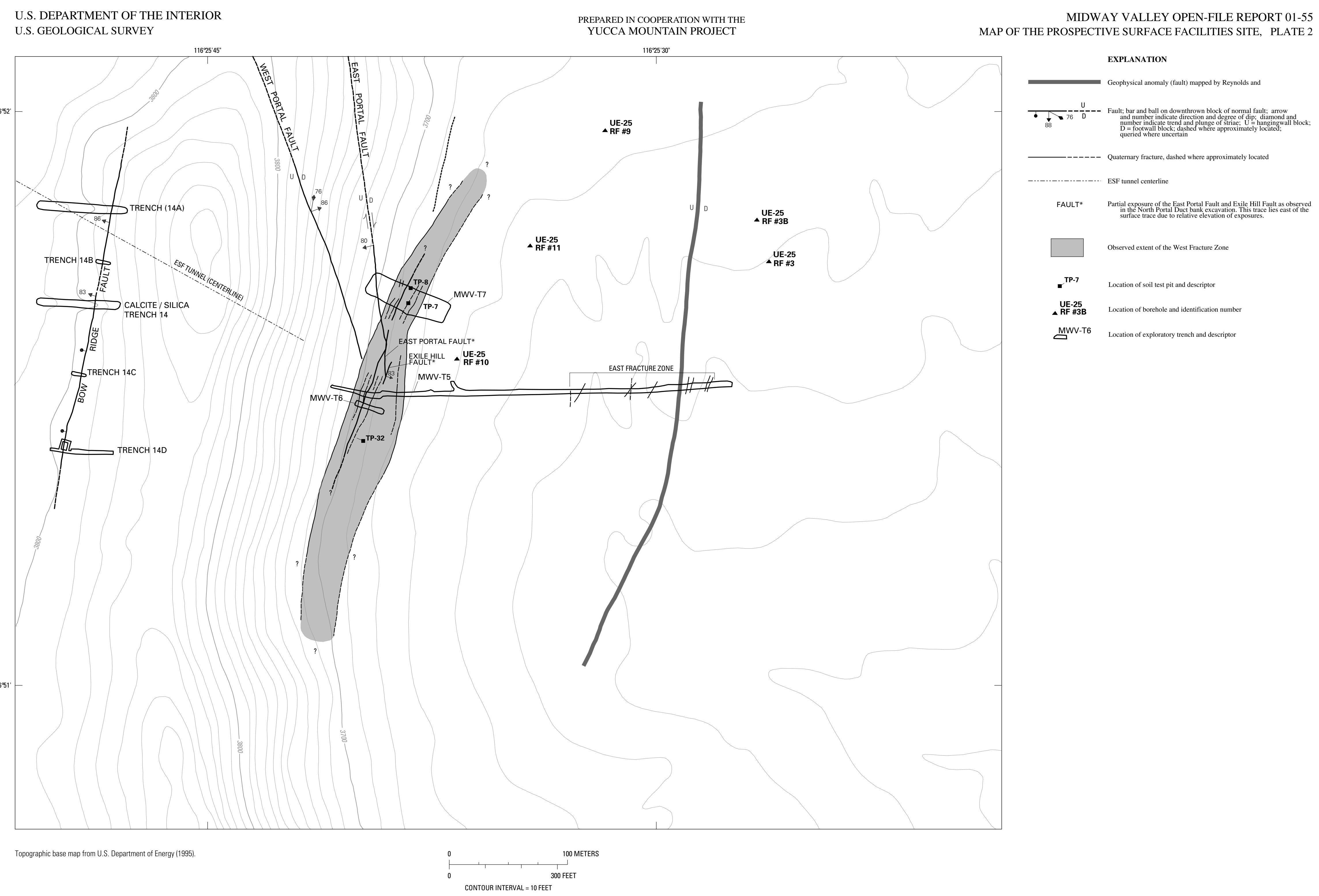

MAP OF THE PROSPECTIVE SURFACE FACILITIES SITE SHOWING FAULTS AND FRACTURE ZONES

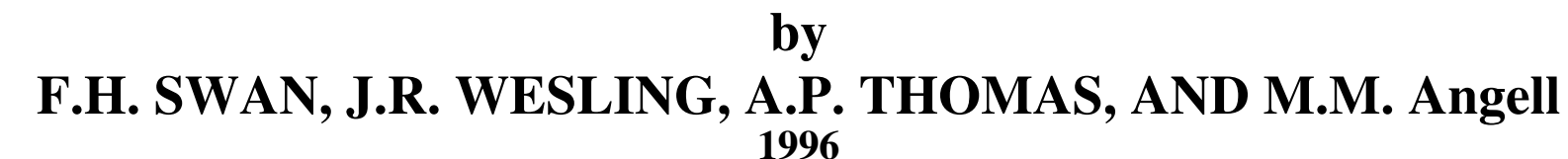




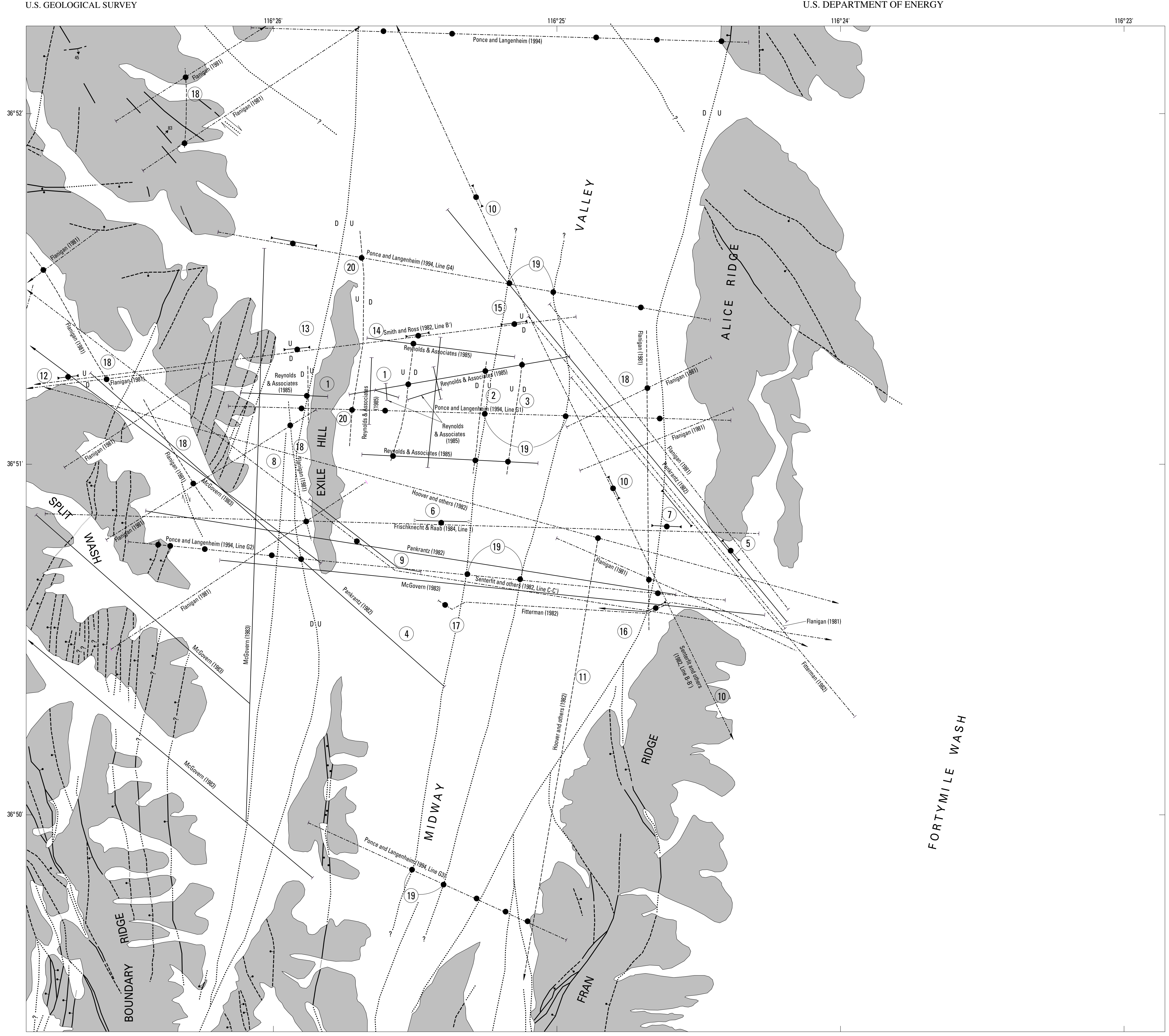

MIDWAY VALLEY OPEN-FILE REPORR DI-SS
GEOPHYSICAL SUUVEY LINES, PLATES

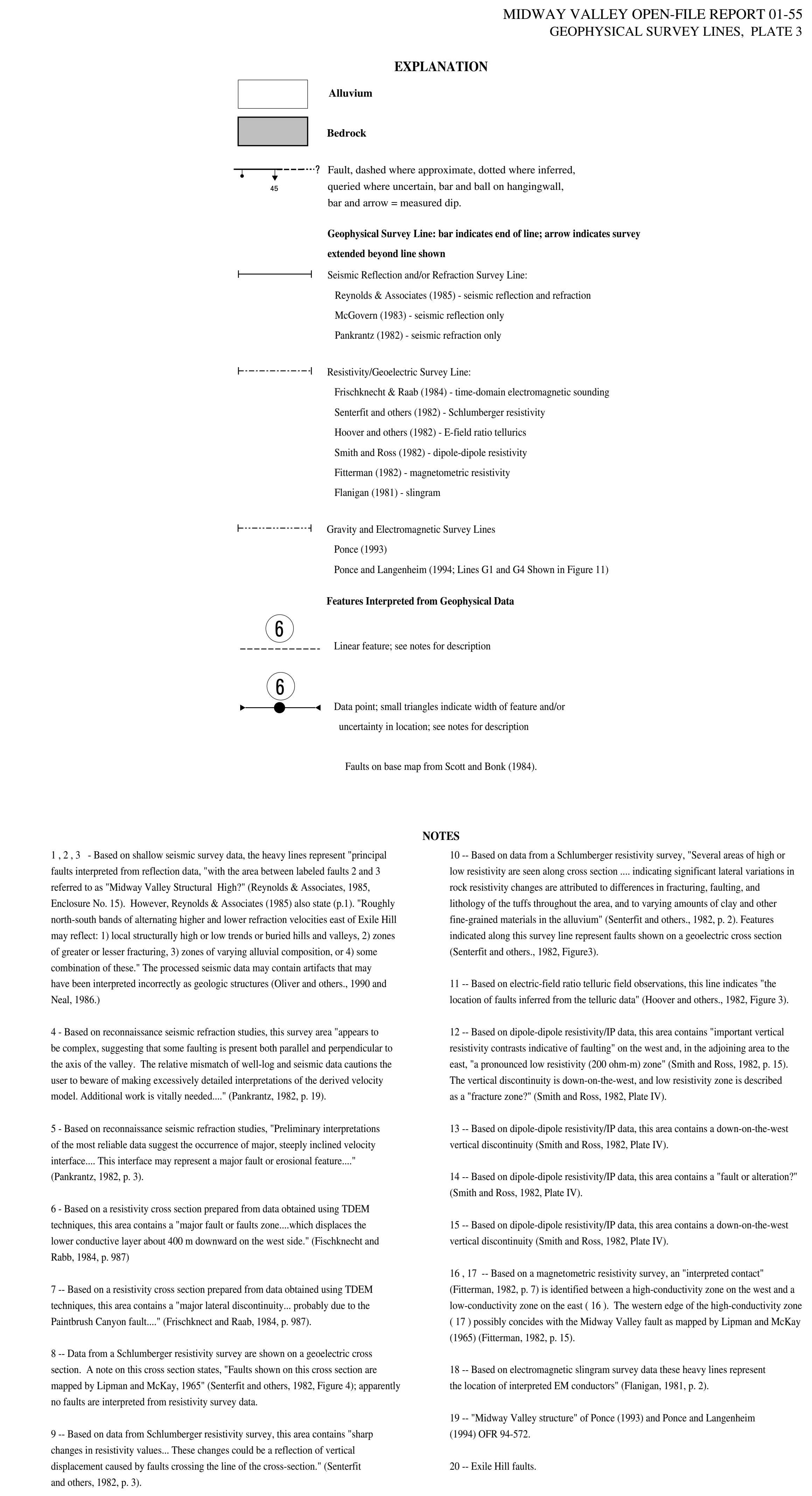

GEOPHYSICAL SURVEY LINES AND FEATURES INTERPRETED FROM GEOPHYSICAL DATA IN MIDWAY VALLEY AND EAST FLANK OF YUCCA MOUNTAIN, NEVADA

by
F.H. Swan and J.R. Wesling
1996 

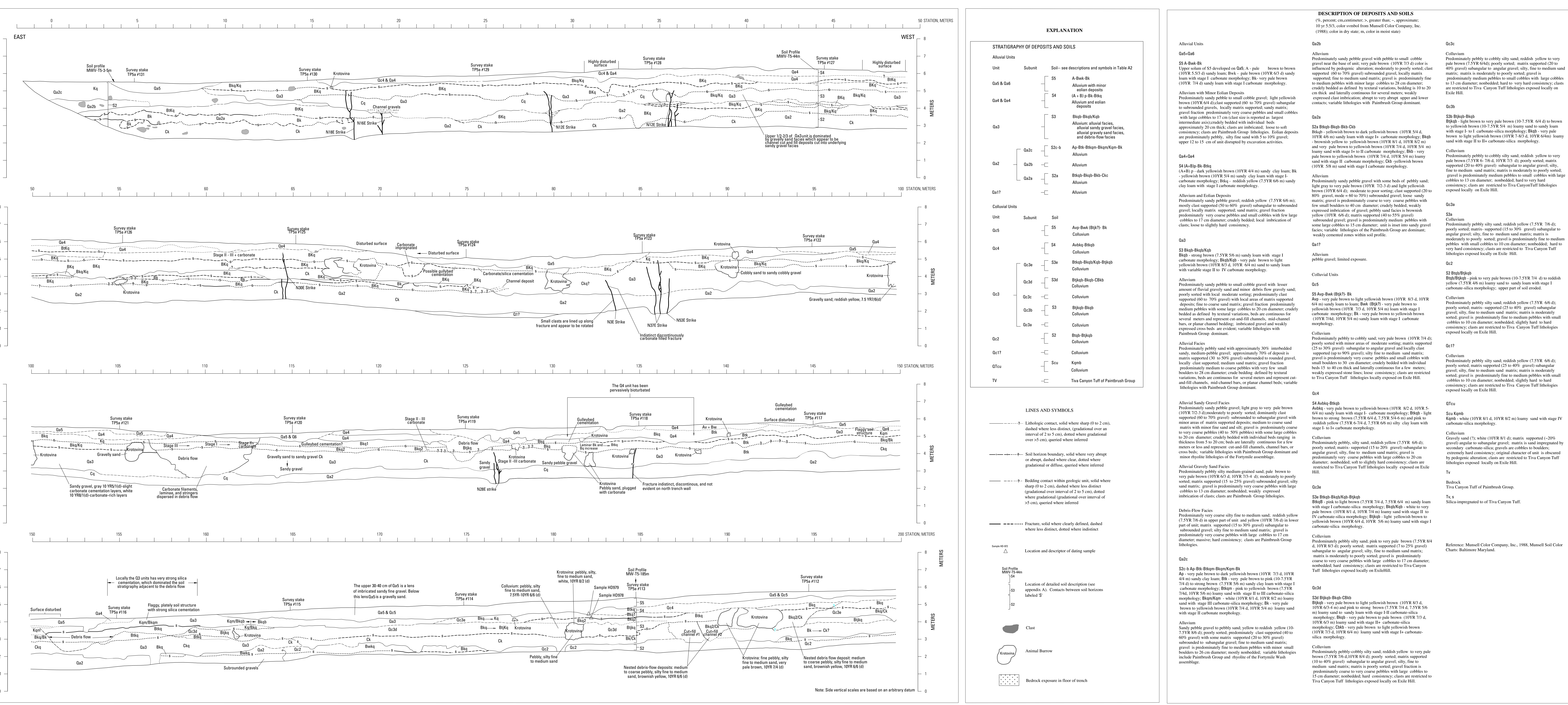

LOG OF SOUTH WALL OF TRENCH MWV-T5 (STATIONS 0-200) IN MIDWAY VALLEY J.R. Wesling, F.H. Swan, A.P. 


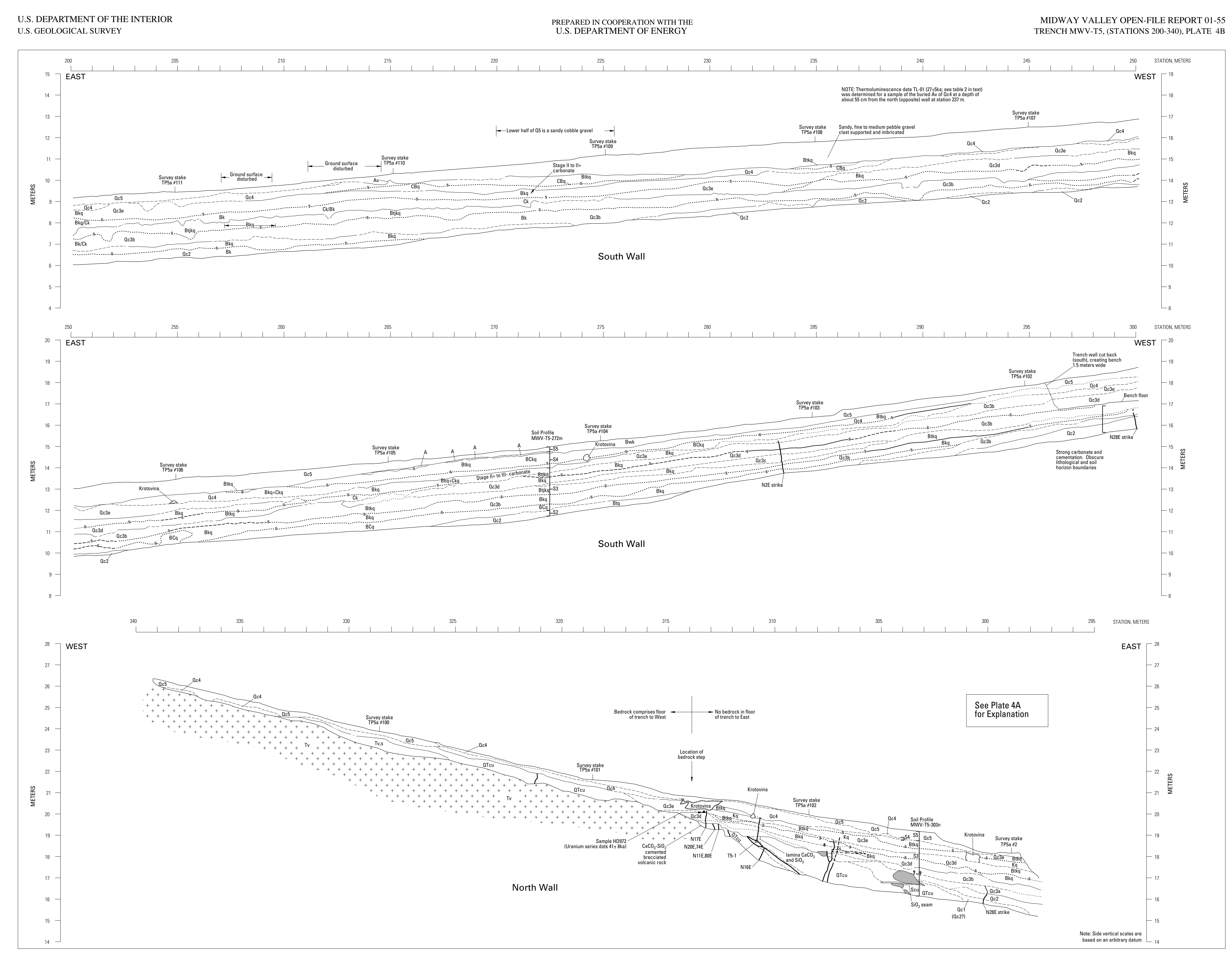

LOGS OF SOUTH WALL (STATIONS 200-300) AND NORTH WALL (STATIONS 295-340) OF TRENCH MWV-T5 IN MIDWAY VALLEY J.R. Wesling, F.H. Swan, A..P. Thomas and M.M. Angell 

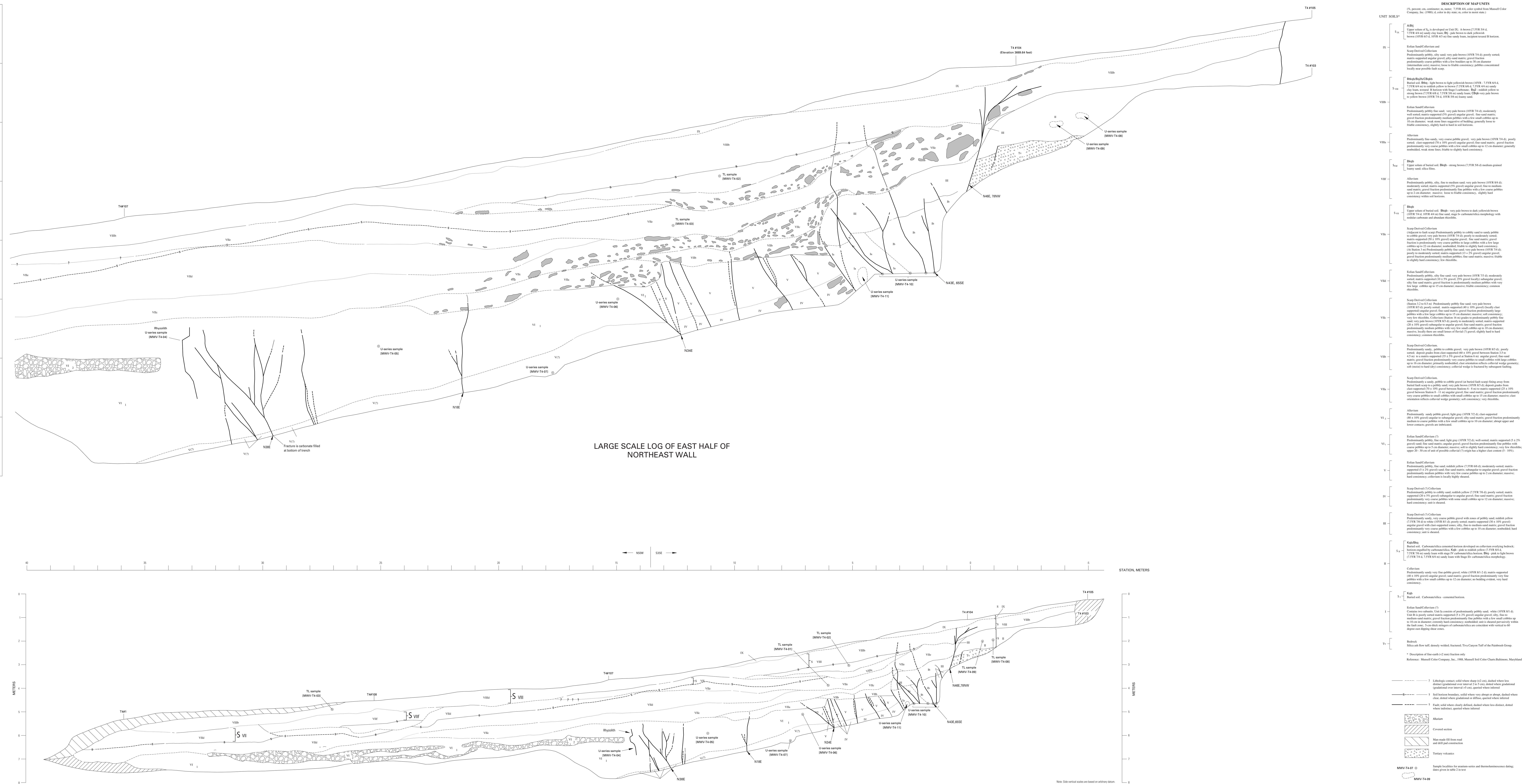


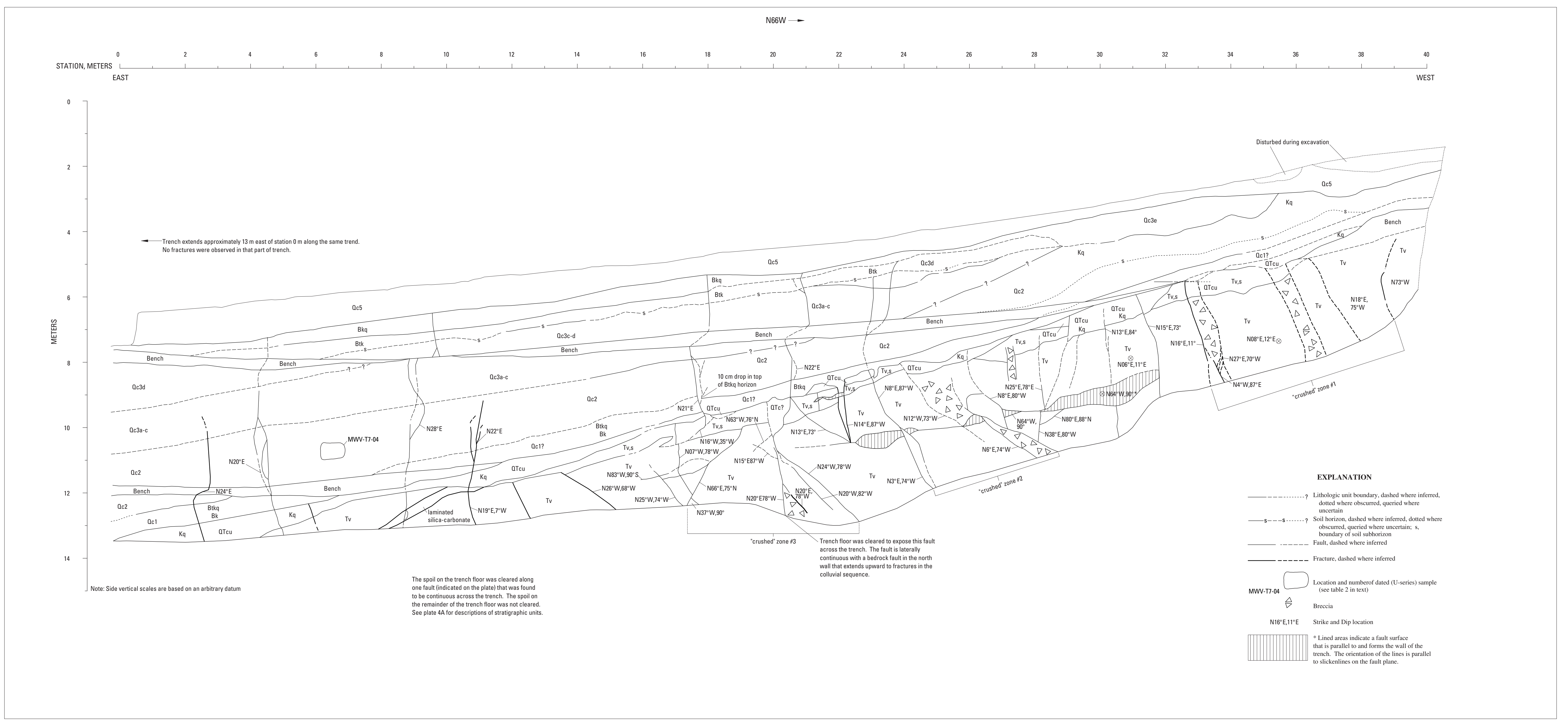

LOG OF SOUTH WALL OF TRENCH MWV-T7 IN MIDWAY VALLEY

M.M. Angell, F.H. Swan, A.P. Thomas, and J.R. Wesling 
and

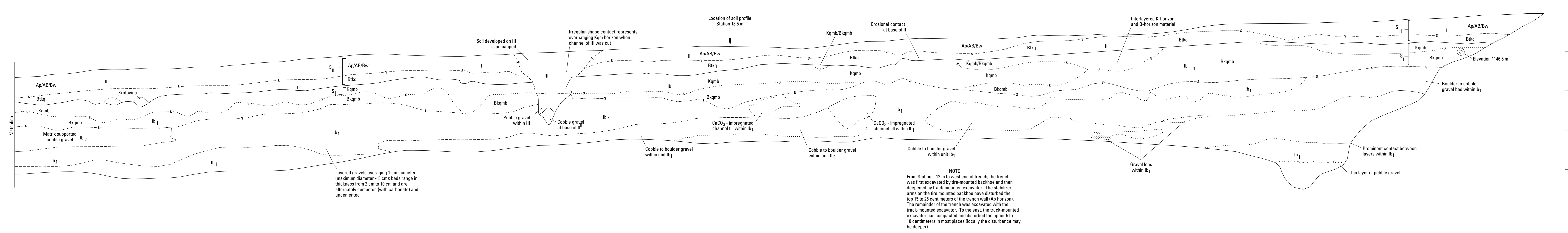

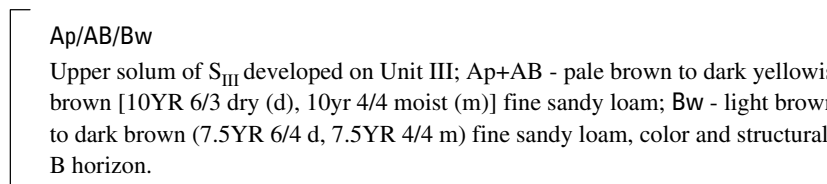

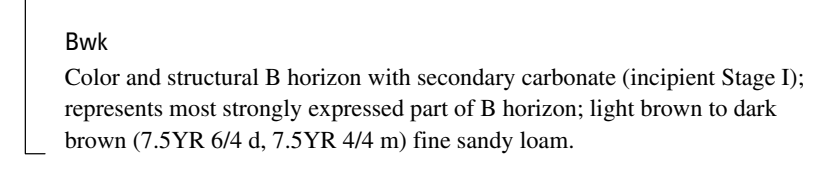

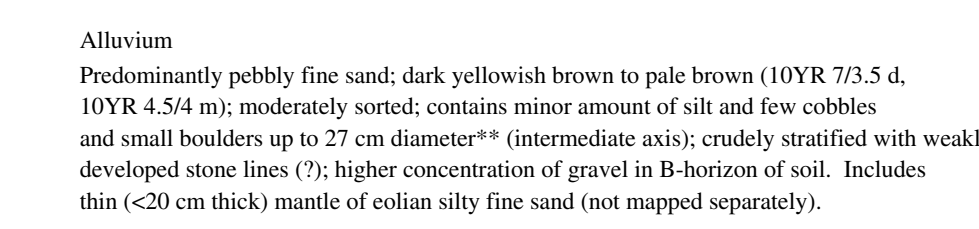

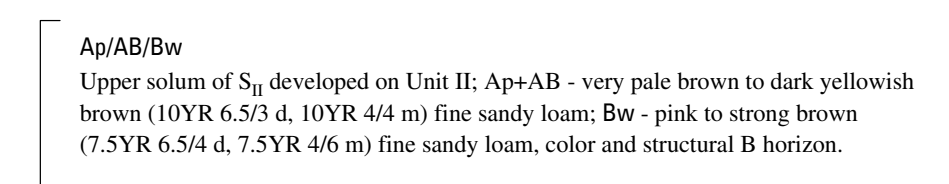

ans

$=$

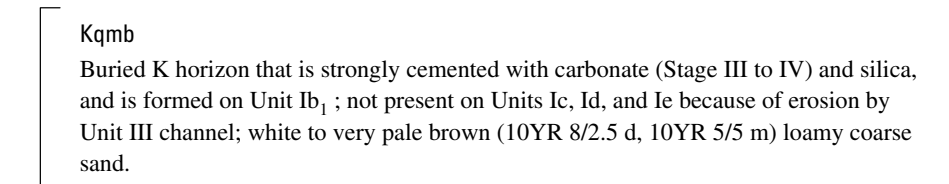

sons

1.

$=$

$=$

$=$

$=$

and

s.t.

$$
\text { (1) }
$$

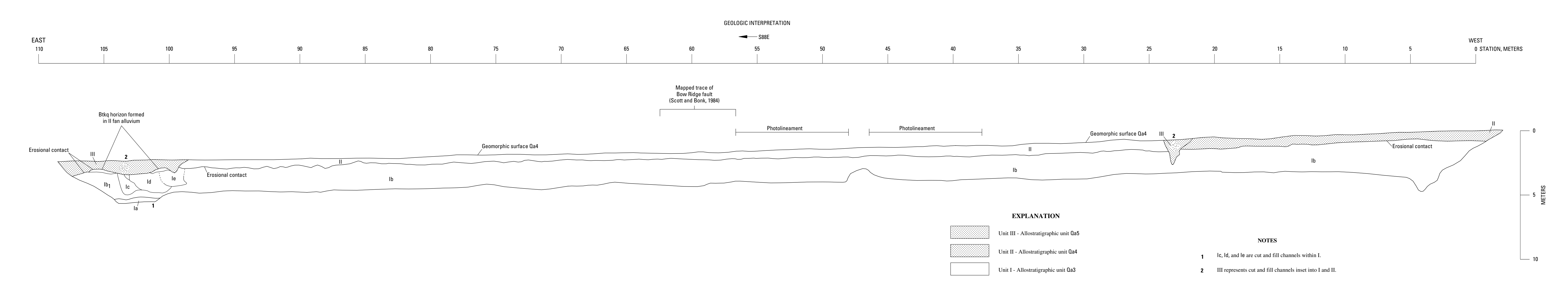




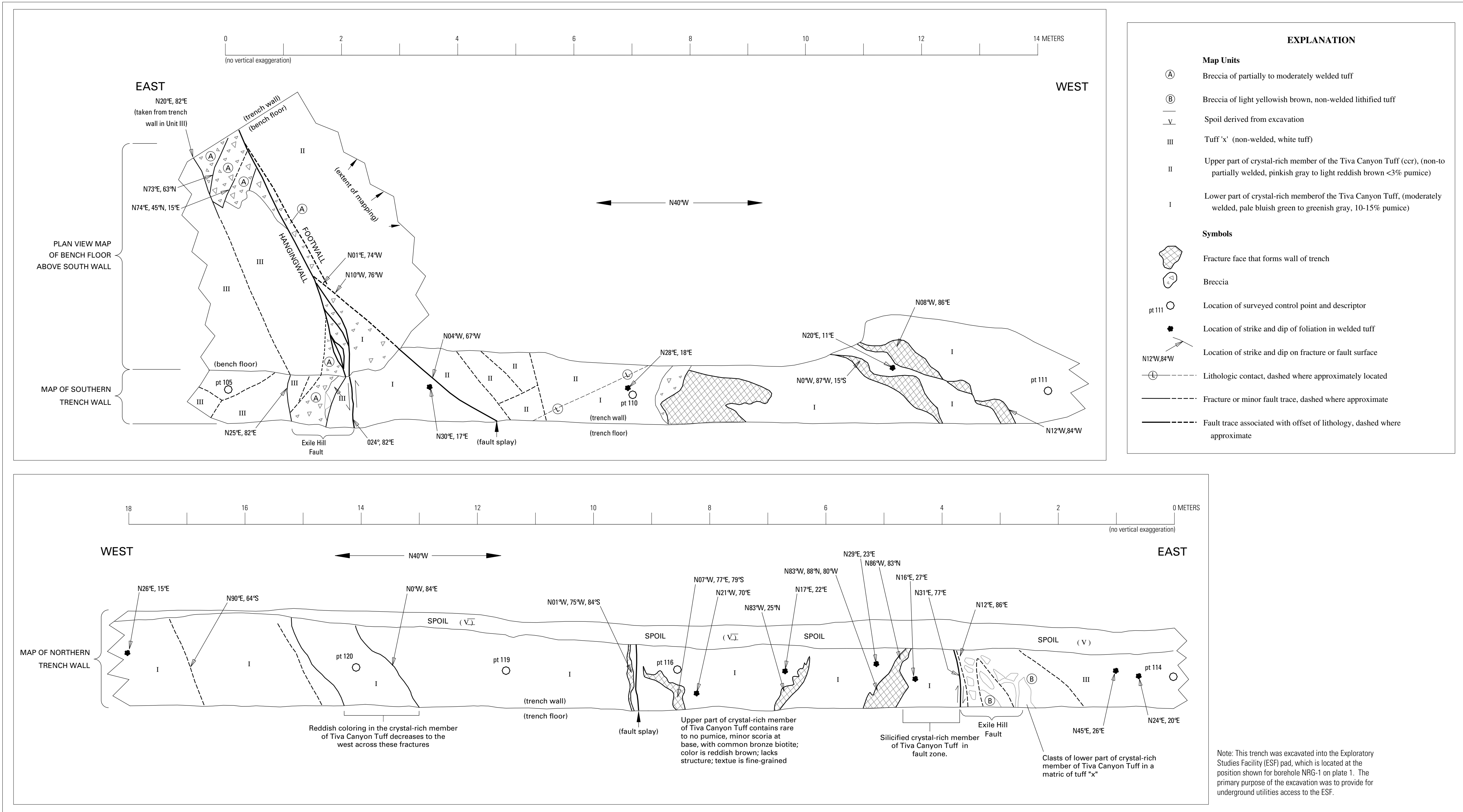

TRENCH WALL AND PLAN VIEW MAPS OF THE NORTH PORTAL DUCT BANK EXCAVATION ON EAST SIDE OF EXILE HILL 


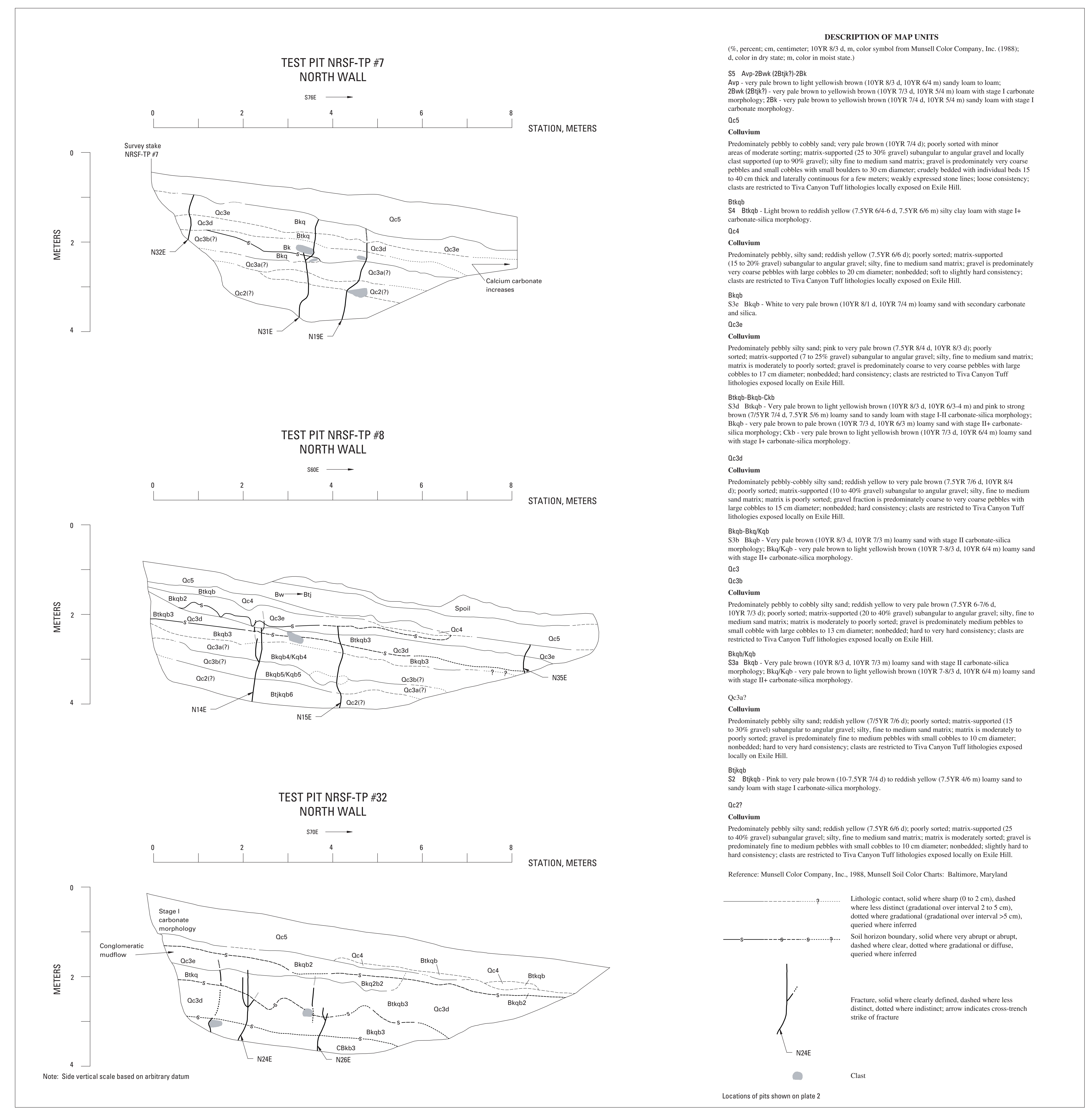

LOGS OF SOIL TEST PITS NRSF-TP7, NRSF-TP8, AND NRSF-TP32

J.R. Wesling and A.P. Thomas 